University of San Diego

Digital USD

Fall 12-16-2014

\title{
Biological and physiological condition of juvenile California halibut (Paralichthys californicus) exposed to a contamination gradient in Mission Bay, CA
}

Kevin Stolzenbach

University of San Diego

Follow this and additional works at: https://digital.sandiego.edu/theses

Part of the Aquaculture and Fisheries Commons, Biochemistry Commons, Cellular and Molecular Physiology Commons, Environmental Health Commons, and the Marine Biology Commons

\section{Digital USD Citation}

Stolzenbach, Kevin, "Biological and physiological condition of juvenile California halibut (Paralichthys californicus) exposed to a contamination gradient in Mission Bay, CA" (2014). Theses. 5.

https://digital.sandiego.edu/theses/5

This Thesis: Open Access is brought to you for free and open access by the Theses and Dissertations at Digital USD. It has been accepted for inclusion in Theses by an authorized administrator of Digital USD. For more information, please contact digital@sandiego.edu. 


\title{
UNIVERSITY OF SAN DIEGO
}

\section{San Diego}

\begin{abstract}
Biological and physiological condition of juvenile California halibut (Paralichthys californicus) exposed to a contamination gradient in Mission Bay, CA
\end{abstract}

A thesis submitted in partial satisfaction of the requirements for the degree of

\author{
Master of Science in Marine Science \\ by
}

Kevin Stolzenbach

Thesis Committee

Dr. Ron Kaufmann, Ph.D., Chair

Dr. Bethany O’Shea, Ph.D.

Dr. Dan Schlenk, Ph.D. 
The thesis of Kevin Stolzenbach is approved by:

\begin{tabular}{c}
\hline $\begin{array}{c}\text { Ron Kaufmann, } \\
\text { University of San Diego }\end{array}$ \\
\hline $\begin{array}{c}\text { Bethany O'Shea, Ph.D. } \\
\text { Universitv of San Diego }\end{array}$ \\
\hline Dan Schlenk, Ph.D. \\
University of California Riverside \\
University of San Diego
\end{tabular}

San Diego

2015 


\section{Copyright 2015 Kevin Stolzenbach \\ DEDICATION}

I would like to dedicate this work to my mom, Christine Stolzenbach, who was a constant source of encouragement and inspiration throughout this process. I wouldn't have made it to where I am without you. Love you, Mom. 


\section{ACKNOWLEDGMENTS}

First I would like to thank my family and friends for supporting me through this process, you've been there to congratulate me on my accomplishments and listen to my problems when things weren't going as smoothly. I would like to thank all the volunteers that assisted me throughout my fieldwork, without them none of this work would have been possible. I would like to thank the Marine Science department and the Biology department at USD for their support throughout the entire project and the San Diego Foundation for sponsoring some of my tuition costs while in school. Special thanks to Wayne Lao at SCCWRP for taking on some of the sediment analyses, and to everyone at the Schlenk lab at UCR for helping me through the lab work and making me feel at home while visiting. Last of all, I would like to thank my committee members for their continual guidance and encouragement (and sometimes gentle reminders of what I should be doing when I wasn't), I've learned a lot along the way and will always be grateful. 


\section{TABLE OF CONTENTS}

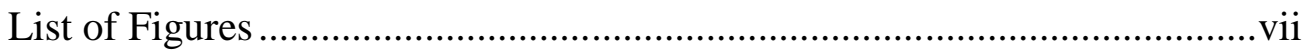



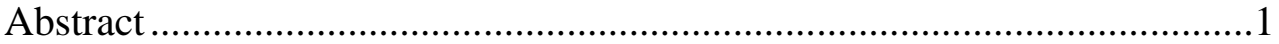

Chapter 1: Introduction

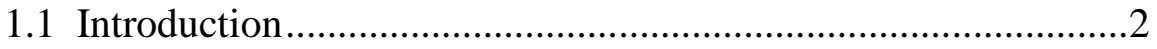

1.1.1 Southern California Bight - Regional Scope ….........2

1.1.2 Sediment Contaminant Dynamics and Toxicity .........3

1.1.3 Biomarkers as Indicators of Exposure to Contaminated

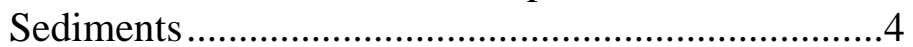

1.1.4 California Halibut ..................................................

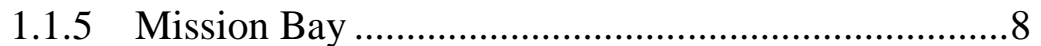

1.2 Statement of hypotheses .......................................................10

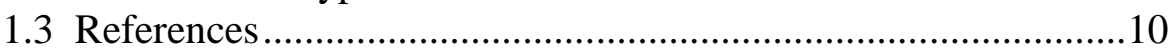

Chapter 2: Distribution of Sediment Contaminants in Mission Bay, San Diego, California

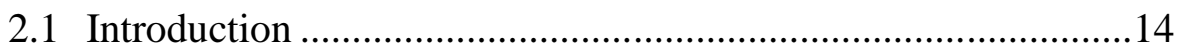

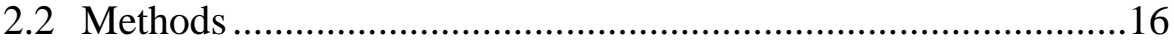

2.2.1 Site Description........................................................17

2.2.2 Field Sampling ……………………………............19

2.2.3 Preparation of Sediments for Analysis ......................20

2.2.4 Grain Size Analysis...............................................20

2.2.5 Metals Analysis...................................................20

2.2.6 Organics: PAHs, Pyrethroids, Fipronil and PBDEs...22

2.2.7 Statistical Analysis...................................................24

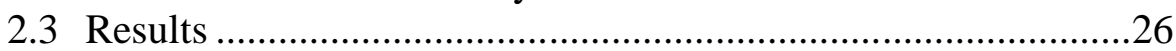

2.3.1 Spatial Variation .....................................................26

2.3.2 Temporal Variation ......................................................30



2.4.1 Effects of Rainfall .....................................................

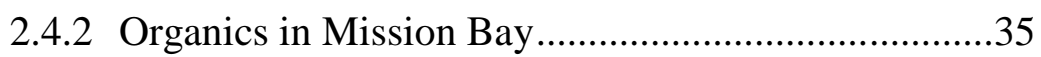

2.4.3 Metals in Mission Bay …………...............................40

2.4.4 Conclusions .............................................................

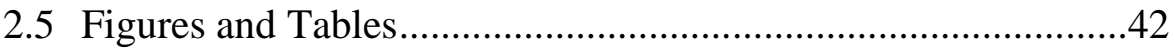



Chapter 3: Morphometric and Biomarker Characteristics of Juvenile California Halibut (Paralichthys californicus) in Mission Bay, San Diego, CA 


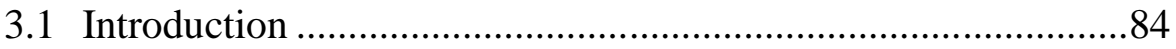

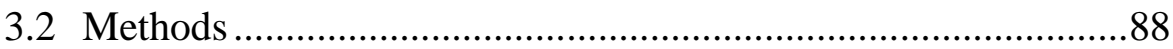

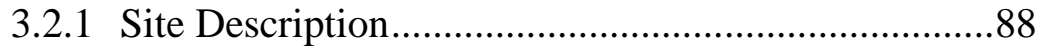

3.2.2 Field Sampling ……………………………............... 89

3.2.3 Lab Processing ……………………………..............90

3.2.4 Tissue Preparation.....................................................90

3.2.5 Biomarker Assays .......................................................90

3.2.6 Statistical Analysis....................................................91

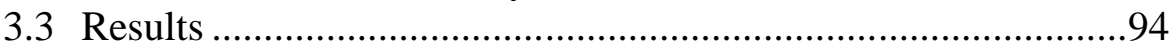

3.3.1 Spatial Variation ........................................................94

3.3.2 Temporal Variation .....................................................99

3.3.3 Correlation Between Biomarkers, Environmental Conditions and Contaminant Concentrations in



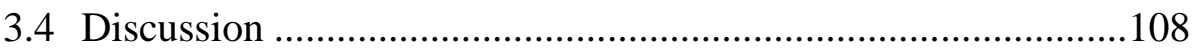

3.4.1 Environmental Parameters and Biomarkers................108

3.4.2 Tissue Biomarkers ....................................................108

3.4.3 Combined Biomarker Indices ...................................112

3.4.4 Comparisons to Previous Juvenile California Halibut



3.4.5 Conclusions............................................................119

3.5 Figures and Tables...............................................................122

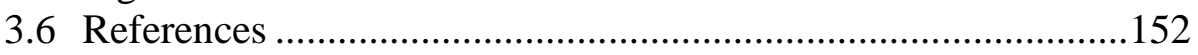

Chapter 4: Summary and Conclusions

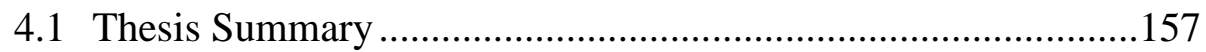

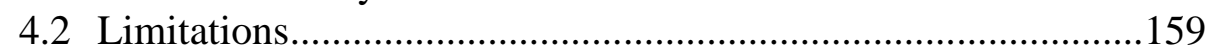



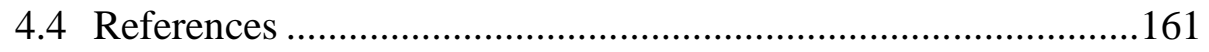

Appendix A: Detailed Biomarker Methods ……………………..................163 


\section{LIST OF FIGURES}

Figure 2.1. Sampling sites in Mission Bay ...................................................... 42

Figure 2.2. Sediment collection sites in Mariner's Cove .................................... 43

Figure 2.3. Sediment collection sites in Ventura Cove ....................................... 44

Figure 2.4. Sediment collection sites in Fiesta Bay ........................................... 45

Figure 2.5. Sediment collection sites in Crown Point ....................................... 46

Figure 2.6. Sediment collection sites in Cudahy Creek ......................................4 47

Figure 2.7. Sediment collection sites in Tecolote Creek.................................... 48

Figure 2.8. Median grain size at beach sites ................................................... 49

Figure 2.9. Median grain size at channel and basin sites ..................................50

Figure 2.10. Percent fine fraction at beach sites ................................................ 51

Figure 2.11. Percent fine fraction at channel and basin sites ........................... 52

Figure 2.12. Pyrethroid, fipronil and PBDEs from 2013 ....................................53

Figure 2.13. PAHs at beach sites .................................................................... 54

Figure 2.14. PAHs at channel and basin sites ................................................. 55

Figure 2.15. Copper at beach sites .................................................................. 56

Figure 2.16. Copper at channel and basin sites ................................................57

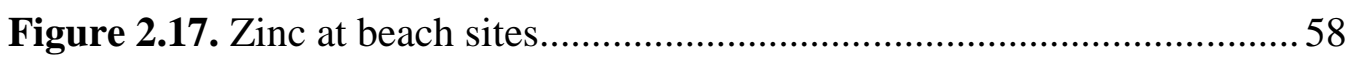

Figure 2.18. Zinc at channel and basin sites .................................................... 59

Figure 2.19. PCO of sediment contaminants by site......................................... 60

Figure 2.20. Rainfall at Sea World 2012-13 and 1999-2013 .............................. 61

Figure 2.21. PCO of sediment contaminants by season..................................... 62

Figure 3.1. Halibut collection areas in Mission Bay ......................................... 122

Figure 3.2. Halibut standard length by season ................................................ 123

Figure 3.3. Halibut hepatic-somatic index by season ....................................... 124

Figure 3.4. Halibut condition factor K by season ............................................. 125

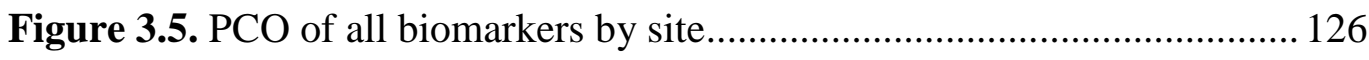

Figure 3.6. $\mathrm{PCO}$ of morphometric biomarkers by site ...................................... 127

Figure 3.7. PCO of cellular biomarkers by site................................................. 128

Figure 3.8. PCO of EROD by site ............................................................... 129

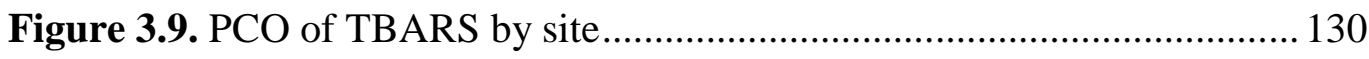


Figure 3.10. PCO of liver biomarkers by site ........................................... 131

Figure 3.11. PCO of kidney biomarkers by site......................................... 132

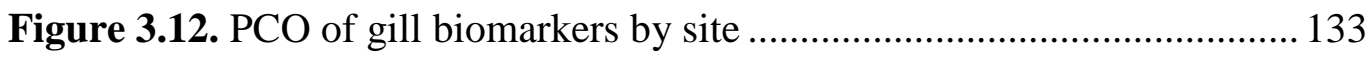

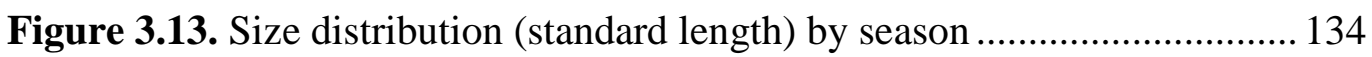

Figure 3.14. PCO of all biomarkers by season ............................................. 135

Figure 3.15. PCO of morphometric biomarkers by season........................... 136

Figure 3.16. PCO of cellular biomarkers by season .................................... 137

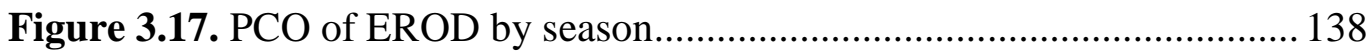

Figure 3.18. PCO of liver biomarkers by season ......................................... 139 


\section{LIST OF TABLES}

Table 2.1. Limit of quantification for sediment contaminants ........................63 63

Table 2.2. Concentrations of contaminants from bulk sediments in 2013 ........ 64

Table 2.3. Fipronils and pyrethroids in bulk sediments in 2013 ..................... 65

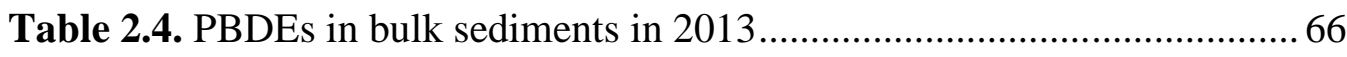

Table 2.5. Total PAHs in bulk sediments in 2013 .......................................67 67

Table 2.6. Total PAHs at each site for each season ........................................ 68

Table 2.7. PAHs in sediments from summer 2012 ....................................... 71

Table 2.8. PAHs in beach sediments from fall 2012 .................................. 72



Table 2.10. PAHs in beach sediments from winter 2012-13 ........................ 74

Table 2.11. PAHs in sediments from spring 2013 .................................... 75

Table 2.12. PAHs in sediments from spring 2014 ...................................... 76

Table 2.13. Copper, lead and zinc in sediments ........................................... 77

Table 2.14. Correlation scores for sediment contaminants ............................ 80

Table 3.1. Halibut size and biomarkers by site .......................................... 140

Table 3.2. PERMANOVA analysis of combined biomarkers ........................ 141

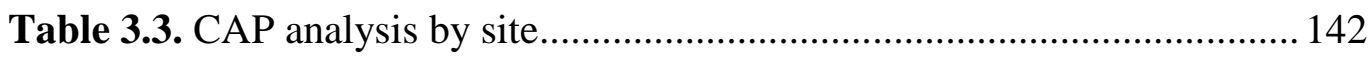

Table 3.4. Halibut size and biomarkers by season ....................................... 143



Table 3.6. Correlation scores for halibut size and biomarkers ........................ 147

Table 3.7. Correlation scores for halibut size and biomarkers to sediments..... 148

Table 3.8 RELATE/BEST scores for biomarkers to environmental parameters

Table 3.9 RELATE/BEST scores for biomarkers to copper, zinc and PAHs ... 150

Table 3.10 RELATE/BEST scores for biomarkers to all sediment contaminants 


\begin{abstract}
Contaminated sediments in marine environments have been shown to be good indicators of ecological risk and a means to assess anthropogenic impacts on marine habitats and the animals that inhabit them (Long et al. 1995, Rattner 2009). Estuarine sediments are especially complex media with regard to physical, chemical, and biological characteristics that trap, store, modify and sometimes release contaminants to the biota (Long et al. 1995). Especially vulnerable are animals that are in constant contact with the sediments, such as flatfishes that partially bury themselves for camouflage (Costa et al. 2011). Impacts can be assessed in a number of ways, one of which involves measuring biomarkers, changes in biological responses ranging from molecular through cellular and physiological responses to behavioral modifications that can be related to the magnitude and duration of exposure (van der Oost et al. 2003). Examining the effects of contaminants on fishes in complex environments requires using multiple biomarkers, which is why a preferred method in areas with sublethal concentrations of contaminants is to use a combined biomarker index to quantify impacts (Sole et al. 2010, Pereira et al. 2010a, b). Juvenile California halibut (Paralichthys californicus) use bays and estuaries as nursery habitats during their first year of life (Forrester and Swearer 2002, Fodrie and Mendoza 2006, Fodrie and Herzka 2013). Studies of young halibut show that they prefer shallow areas with fine sediments and gradually move into deeper, sandier habitats as they grow (Fodrie and Herzka 2008, Lopez-Rasgado and Herzka 2009). In Mission Bay, San Diego, higher concentrations of multiple inorganic and organic contaminants have been found in the back bay (which is shallow with fine sediment and receives input from storm water outfalls) and in boat basins, although not at levels that are acutely fatal to juvenile halibut (Stransky 1999). Some contaminants of interest in Mission Bay are heavy metals $(\mathrm{Cu}, \mathrm{Pb}, \mathrm{Zn})$ and compounds associated with anthropogenic inputs, like petroleum hydrocarbons, pesticides and other organic contaminants that have the potential to bioaccumulate. The purpose of this project was to compare contaminant concentrations in sediments to liver, kidney and gill biomarkers in juvenile California halibut caught in different parts of Mission Bay to examine relationships between the distribution of contaminants in Mission Bay and physiological condition of juvenile halibut.
\end{abstract}




\section{Chapter 1.0 - Introduction}

\subsubsection{Southern California Bight - Regional Scope}

The Southern California Bight (SCB) is the $400 \mathrm{~km}$ curved stretch of coastline that extends south from Point Conception to the US-Mexico border. This region of coastline is the second most densely populated coastal region in the United States, with over 17 million residents in the metropolitan regions of Los Angeles, Orange and San Diego (www.census.gov/population/www/metroareas/ metroarea.html). This area is highly developed with expansive freeway networks and urbanized with over 6 million housing units (quickfacts.census.gov). Southern California has a Mediterranean climate that experiences hot, dry summers and cool, rainy winters. Rain events are often intermittent and can have long periods between them, which means that when a large storm does occur, accumulated contaminants can be transported from the watershed into the marine ecosystem, and can lead to toxicity for organisms within these systems (Kayhanian et al. 2008).

Estuaries represent a transition between terrestrial and marine habitats. They are extremely rich systems that support high levels of productivity for plankton (Elliott and Kaufmann 2007), seagrasses (Johnson et al. 2003) and fishes (Kramer 1991, Lopez-Rasgado and Herzka 2009). Estuaries show a gradient in water properties as one moves from the mouth of the estuary to its inner reaches. This gradient is affected greatly by the amount of natural and anthropogenic input into the estuary from various sources, such as rivers, urban runoff and industrial discharges (Kayhanian et al. 2008). Mediterranean estuaries have recurrent seasonal cycles of hyper- and hyposalinity caused by long dry summers and rainy wet winters (hereafter wet seasons), although the cycles are not always consistent in duration, depending on latitude (Largier et al. 1997). Especially in shallow estuaries, hypersalinity creates low density gradients with limited vertical mixing and long residence times that can be exaggerated in the inner reaches (Largier et al. 1997). 


\subsubsection{Sediment Contaminant Dynamics and Toxicity}

Generally, contaminants enter coastal and estuarine waters through riverine input and anthropogenic activities (Kayhanian et al. 2008). Within these systems, contaminants partition into aqueous (pore water, overlying water) and solid phases (sediment, suspended particulate matter and biota). The partitioning behavior and spatial distribution of contaminants are highly regulated by the hydrodynamics, biogeochemical processes and environmental conditions (e.g. redox, $\mathrm{pH}$, salinity, temperature) of the individual system (Long et al. 1995, Kayhanian et al. 2008). Sediments have been shown to be good indicators of habitat quality, as they have the ability to sequester and release contaminants (Costa et al. 2011, Fonseca et al. 2011a). This means that they can be a source of long-term exposure of biota to persistent chemicals and offer short-term storage of more readily mobilized/metabolized compounds (Long et al. 1995). Seasonality of rainfall may affect when contaminants are delivered from watersheds to estuaries and when they are sequestered/released by the sediments (Kayhanian et al. 2008, Brown et al. 2013).

Generally, fine-grained, organic-rich sediments bind organic contaminants readily and could be considered a reservoir that keeps these contaminants from becoming bioavailable (Long et al. 1995, Duong et al. 2009). Sediment disturbance can lead to changes in the chemical and physical properties of sediment that stimulate the mobilization of contaminants. Changes in both redox potential (Eh) and $\mathrm{pH}$ can accelerate desorption, partitioning from particulate to dissolved phases, bacterial degradation and the oxidation of organic contaminants, although these processes are compound- and sediment-specific (Pereira et al. 2010a, b, Costa et al. 2011). The nature of chemical interactions within systems like estuaries is likely to affect the mobilization of contaminants, although these dynamics are very complex. Remobilization of sediment-associated contaminants can occur during natural events, such as tidal movement and storms, or as a result of human activities, such as dredging, disposal of dredge spoils and fishing (Long et al. 1995). 
Regional monitoring of the Southern California Bight over the past ten years has tracked a variety of contaminants in sediments within embayments and on the continental shelf. The Bight '08 study led by the Southern California Coastal Water Research Project (SCCWRP) found that in general the patterns of sediment contamination are mixed. Embayments were more contaminated compared to offshore sediments, which is not surprising given the extent of urbanization in the region. While in the past ten years bays/harbors/ports have improved in terms of acceptable sediment condition from $46 \%$ to $62 \%$, estuaries have shown a decrease in acceptable condition in just the past five years, from $86 \%$ to $62 \%$. Some contaminants are better studied and have been tracked over long time periods, like metals and DDT, while some are considered contaminants of emerging concern, such as pyrethroid pesticides and PBDEs (Schiff et al. 2011, Dodder et al. 2012, Lao et al. 2012, Mayura et al. 2012). The survey found that pyrethroids, a class of pesticides, and PBDEs, flame retardants found in numerous consumer products, were in high enough concentrations to cause toxicity in the lab (Schiff et al. 2011). These findings are supported by subsequent studies in which these compounds were found in embayments that received runoff from urban watersheds and rivers (Dodder et al. 2012, Lao et al. 2012), although toxicity was not well correlated with sediment concentrations alone (Greenstein et al. 2013). This suggests that urban areas are a significant source of these new compounds and more work is needed to characterize their presence and effect on biological communities.

\subsubsection{Biomarkers as Indicators of Exposure to Contaminated Sediments}

It is useful to be able to quantify the contaminants found in marine and estuarine sediments. However, this ability gives little basis for estimating the potential adverse effects on biota associated with contaminated sediment (Ratner 2009). A variety of biological measures, including toxicity and/or bioaccumulation tests, can help to determine the biological significance of sediment-associated contaminants (Van der Oost et al. 2003, Schiff et al. 2011). 
Fishes are particularly sensitive to a broad range of contaminants, even at sublethal levels, and can experience effects such as respiratory anomalies, electrolytic imbalance, tissue lesions, DNA damage, endocrine disruption and metabolic stress (Brown and Steinert 2003, Roy et al. 2003a, Pereira et al. 2010a). The route of exposure is also an important consideration for toxicological studies of fishes, as contaminants can be taken up via ingestion of food (particulateassociated chemicals), membrane-facilitated active transport or passive diffusion of chemicals dissolved in water (Minghetti et al. 2008, Costa et al. 2011). Laboratory assays are effective for identifying responses to a single contaminant, but field conditions rarely involve exposure to a single contaminant and can lead to misinterpretation of mechanisms given the cocktail effect of multiple contaminants in the environment having inhibitory, additive, and multiplicative effects (Celander 2011, Lu et al. 2013). Bringing marine sediments back to the lab in an attempt to control more variables also has its problems (Roy 2003b, Lu et al. 2013). Costa et al. (2011) observed significantly more hepatic lesions on Senegalese sole (Solea senegalensis) caged in situ in the Sado Estuary (Portugal) compared to sole exposed in the lab to sediments from the same estuary. The authors attributed this difference to unintended assay-induced effects that affected bioavailability in the lab and unmanageable variables like access to food. Examining biological indicators of contaminant exposure as well as sediment chemistry can help to identify areas in which the potential for biological effects is greatest (Pereira et al. 2010a, b).

Traditionally, measurements of contaminant concentrations in water and sediments have been used to assess the health of coastal marine habitats. However, since it is virtually impossible to predict the bioavailability of xenobiotic substances in aquatic environments with simple partitioning models, other approaches such as bioaccumulation models in fishes can be used to trace substances as they move through the ecosystem (van der Oost et al. 2003). Bioaccumulation models are also difficult to use broadly across taxa, as many factors (e.g. toxicokinetics, metabolism, organ-specific bioaccumulation) can vary with species (Eggleton and Thomas 2004). Thus, analyses of tissue levels or 
body burdens have been suggested when working with target organisms that have not been examined previously (van der Oost et al. 2003). Although this approach is good for comparisons between environmental and tissue concentrations, it does not give an indication of the general health of the organism, and the complex nature of contaminant mixtures can affect tissue loading in certain organs (Costa et al. 2009, 2011). Also, some contaminants are more persistent in the environment (e.g. PCBs, PBDEs and DDT) than those that are readily metabolized into other forms (e.g. PAHs). An integrative approach for marine organisms that combines environmental conditions with chemical and biological responses can be effective for detecting sublethal effects in both invertebrates and fishes that are not detected by commonly used acute toxicity tests that examine embryo development and amphipod survival over short time scales (Livingstone 1998, Pereira et al. 2010b, Schiff et al. 2011, Greenstein et al. 2013).

There are a number of biomarkers that are thought to reflect contaminant exposure in fishes. However, only some biomarkers are understood well enough or show strong enough correlations to contaminant loads to be considered for this study. The first is the activity of the phase I biotransformation enzyme ethoxyresorufin O-deethylase (EROD), which is a measure of cytochrome P4501A monooxygenase. As part of a group of enzymes that are responsible for metabolizing xenobiotic compounds in the liver, EROD has been shown to be particularly sensitive to planar organic contaminants such as PCBs and PAHs (Whyte et al. 2000, van der Oost et al. 2003). EROD can be influenced by some abiotic variables, such as salinity and temperature (Kopecka-Pilarczyk 2013), and shows high variation between species (Fonseca et al. 2011a, b). The second biomarker is lipid peroxidation (LPO), measured as the formation of thiobarbituric acid reactive substances (TBARS), which results from oxidation of polyunsaturated fatty acids. LPO is an indication that reactive oxygen species (ROS) exceed the antioxidant defenses of the cells, which may cause more extensive damage (van der Oost 2003, Martnez -'lvarez et al. 2005). Therefore, lipid peroxidation is a non-specific biomarker and can be an indicator of cellular damage. 
The tissues that are most commonly analyzed for biomarkers are those that are constantly exposed to the environment and/or responsible for transformation, storage, and excretion of xenobiotic compounds. The most intuitive choice is the liver, which plays a primary role in the metabolism, storage and excretion of xenobiotics (Costa et al. 2009, Pereira et al. 2010a). The kidney also plays a major role in the metabolism and excretion of xenobiotics and has hematopoietic, endocrine and immune functions, making this organ a good candidate for biomarker analysis (Pereira et al. 2010a). The gills are also good targets for analysis, due to their constant exposure to the environment, their role in excretion, and the fact that they receive almost all of the cardiac output of the fish before the blood is circulated to other tissues (Costa et al. 2009, Pereira et al. 2010b).

\subsubsection{California Halibut}

California halibut (Paralichthys californicus) is a commercially and recreationally important flatfish found in the eastern Pacific from Washington State to Almejas Bay, Baja California. It is most common south of Bodega Bay, with the center of distribution near San Diego and northern Baja California (CA

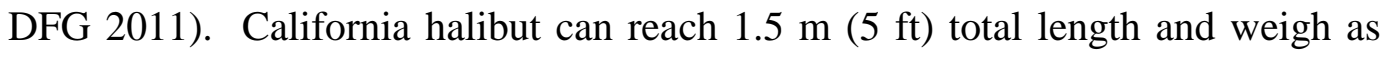
much as $33 \mathrm{~kg}(72 \mathrm{lb})$. Since 1981, total landings peaked at $602.4 \mathrm{t}$ with a value of $\$ 3.26$ million in 1997 , and hit a low in 2007 with a total landing of $176.3 \mathrm{t}$ and a value of $\$ 1.84$ million. Total landings in 2011 were $199.7 \mathrm{t}$ worth $\$ 2.17$ million (CA DFG 2011). The Southern California fishery was estimated to be at $14 \%$ of historic levels, but thought to be sustainable at the current level of harvest (CA DFG 2011). Adults prefer sandy habitats near rocky reefs and are caught in the highest densities in less than $75 \mathrm{~m}$ water depth and within $6 \mathrm{~km}$ of shore (Kramer 1991). Females grow faster and to a larger size than males, and become sexually mature between 5 and 6 years of age, compared to the males, which reach

maturity between 1 and 3 years of age (CA DFG 2011). They spawn throughout the year, although there is a peak during the winter and spring (Forrester and Swearer 2002, Fodrie and Mendoza 2006, Fodrie and Herzka 2008). 
The larval stage is planktonic for 30-70 days, after which larvae migrate to coastal bays or estuaries and metamorphose to their demersal juvenile form (Haugen 1990). Halibut use these areas as nursery habitat, although some use shallow inshore areas and do not migrate into bays or estuaries. Bays are preferred by juveniles due to benefits like abundant food, fewer predators and increased growth rates in warmer waters (Stransky 1999, Lpez -Rasgado and Herzka 2009). Juveniles prey primarily on small benthic invertebrates such as mysids, copepods, polychaetes and amphipods. As they grow, halibut tend to become more piscivorous, and their preferred prey in Mission Bay is the cheekspot goby, Ilypnus gilberti (Haugen 1990, Kramer 1991). Juveniles are susceptible to larger fishes that inhabit the bay, such as thornback rays and kelp bass, while adults are preyed upon by marine mammals, such as California sea lions, and humans (Kramer 1991, Stransky 1999). Younger juveniles are thought to use shallow habitats near eel grass beds, and move into deeper habitats as they age (Fodrie and Mendoza 2006, Fodrie and Herzka 2008). California halibut remain in these nursery habitats for about one year before migrating to deeper "adult" habitats (Forrester and Swearer 2002). Through otolith microchemistry it has been seen that adults that migrate out of bays tend to stay close to their nursery habitat, usually within $10 \mathrm{~km}$ (Fodrie and Herzka 2013, Forrester and Swearer 2002). San Diego has two large bays, San Diego Bay and Mission Bay, both of which serve as nursery areas for juvenile halibut (Stransky 1999, Forrester and Swearer 2002) and as habitat for older halibut (Kramer 1991, pers. obs).

\subsubsection{Mission Bay}

Mission Bay is approximately $9.26 \mathrm{~km}^{2}$ (2,287 acres) and averages 1.2-3.6 $m$ in depth MLLW (Stransky 1999). It contains the Kendall-Frost Wildlife Preserve and the adjacent Northern Wildlife Preserve, which protect a total of $0.16 \mathrm{~km}^{2}$ (40 acres) of salt-marsh, mudflats, tidal channels, widgeongrass (Ruppia maritima) and eel grass (Zostera marina) habitat near the Rose Creek mouth. The bay is permanently open to tidal exchange, although the western portion (front bay) is better flushed by tides than the back bay. The back bay is generally 
shallow, shows lower water quality compared to the rest of the bay, and has finegrained sediments with high organic content (Stransky 1999, Kaufmann et al. 2004, 2006, Fodrie and Herzka 2008). The channel is open to the ocean, has a maximum depth of $6.6 \mathrm{~m}$ MLLW and experiences the most boat traffic in the bay, as it is the only connection to the ocean and is near Quivira Basin, the largest boat basin in the bay. There is strong seasonality in the bay that affects physical and chemical conditions. The summer is dry, and the back bay experiences high levels of evaporation that make it warmer and saltier than the front bay. The winter is the wet season, although the amount of precipitation can vary greatly from year to year (Largier et al. 1997, Elliott and Kaufmann 2007). Winter rains produce runoff that enters the bay and creates cooler, less saline conditions in the back bay compared to the front bay (Elliot and Kaufmann 2007). Major sources of input to the bay include a total area of $147 \mathrm{~km}^{2}$ drained by the watersheds of three major creeks: Rose, Tecolote and Cudahy. There are no direct sources of industrial or municipal waste, although during larger rainfall events, storm drains that normally are diverted to a wastewater treatment plant instead empty directly into Mission Bay via 100 outfalls around the bay (Stransky 1999).

Stransky (1999) found that most sediment contaminant concentrations in Mission Bay were lower than those in the heavily polluted San Diego Bay. However, concentrations of total petroleum hydrocarbons, pyrethroids, and PBDEs near the Tecolote Creek mouth in Mission Bay were similar to those found in Commercial Basin of San Diego Bay (Stransky 1999, Schiff et al. 2011, Lao et al. 2012). Likely sources of these organic contaminants in Mission Bay are urban street runoff and boat traffic. Sediments collected from the back bay and boat basins in Mission Bay showed chemical loads that were above the EPA ERL (Effects Range Low) benchmark for arsenic, copper, lead, mercury, nickel, zinc, DDT, DDE and PCBs, while chlordane was found to be at a concentration above the ERM (Effects Range Median) benchmark (Stransky 1999). Similar results were reported from quarterly sampling of sediments in Mission Bay between May 2004 and May 2005 (Kaufmann et al. 2006, Stransky and Kaufmann 2010). 
In the lab, Stransky (1999) exposed juvenile halibut to sediments from various parts of Mission Bay for 28 days and did not see any significant impacts on growth or mortality but did observe fin rot and behavioral modifications such as sediment avoidance in fish exposed to the most contaminated sediments. The physiological condition of California halibut in Mission Bay has never been assessed in relation to environmental contaminants in the field.

\subsection{Statement of Hypotheses}

$\mathrm{H}_{0} 1$ : There is no difference between sediment contaminant concentrations in the back vs. the front of Mission Bay

$\mathrm{H}_{0}$ 2: Sediments in Mission Bay show no temporal variation in terms of sediment contaminant concentrations

$\mathrm{H}_{0}$ 3: Halibut show the same biomarker responses regardless of which region of the bay they are caught in

$\mathrm{H}_{0} 4$ : Biomarker responses will not be different among tissues or between combined biomarker indices

\subsection{References}

Brown, J.S. and Steinert, S.A. 2003. DNA damage and biliary PAH metabolites in flatfish from Southern California bays and harbors, and the Channel Islands. Ecological Indicators 3: 263-274.

Brown, J.S., Stein, E.D., Ackerman, D., Dorsey, J.H., Lyon, J. and Carter, P.M. 2013. Metals and bacteria partitioning to various size particles in Ballona Creek storm water runoff. Environmental Toxicology and Chemistry 32: 320-328.

California Department of Fish and Game. 2012. Review of selected California fisheries for 2011: ocean salmon, California sheephead, California halibut, longnose skate, petrale sole, California spiny lobster, dungeness crab, garibaldi, white shark and algal blooms. Fisheries Review (CalCOFI Report) 53: 1-40.

Celander, M.C. 2011. Cocktail effects on biomarker responses in fish. Aquatic Toxicology 1055: 72-77.

Costa, P.M, Caeiro, S., Diniz, M.S., Lobo, J., Martins, M., Ferreira, A.M., Caetano, M., Vale, C., DelValls, T.A. and Costa M.H. 2009. Biochemical endpoints on juvenile Solea senegalensis exposed to estuarine sediments: effect of contaminant mixtures on metallothionein and CYP1A induction. Ecotoxicology 18: 988-1000.

Costa, P.M., Diniz, M.S., Caeiro, S., Lobo, J., Martins, M., Ferreira, A.M., Caetano, M., Vale, C., DelValls, T.A., and Costa M.H. 2009. Histological biomarkers in liver and gills of juvenile Solea senegalensis exposed to contaminated estuarine sediments: A weighted indices approach. Aquatic Toxicology 92: 202-212.

Costa, P.M., Caeiro, S., Lobo, J., Martins, M., Ferreira, A.M., Caetano, M., Vale, C., DelValls, T.A. and Costa, M.H. 2011. Estuarine ecological risk based on hepatic 
histopathological indices from laboratory and in situ tested fish. Marine Pollution Bulletin 62: 55-65.

Dodder, N.G., Maruya, K.A., Lauenstein, G.G., Ramirez, J., Ritter, K.J. and Schiff, K. 2012. Distribution and sources of polybrominated diphenyl ethers in the Southern California Bight. Environmental Toxicology and Chemistry 31: 2239-2245.

Duong, C.N., Schlenk, D., Chang, N.I. and Kim, S.D. The effect of particle size on the bioavailability of estrogenic chemicals from sediments. Chemosphere 76: 395-401.

Elliott, D.T. and Kaufmann, R.S. 2007. Spatial and temporal variability of mesozooplankton and tintinnid ciliates in a seasonally hypersaline estuary. Estuaries and Coasts 30: 418-430.

Ferreira, M., Antunes, P., Gil, O., Vale, C. and Reis-Henriques, M.A. 2004. Organochlorine contaminants in flounder (Platichthys flesus) and mullet (Mugil cephalus) from Douro estuary, and their use as sentinel species for environmental monitoring. Aquatic Toxicology 69: 347-357.

Ferreira, M., Moradas-Ferreira, P. and Reis-Henriques, M.A. 2005. Oxidative stress biomarkers in two resident species, mullet (Mugil cephalus) and flounder (Platichthys flesus), from a polluted site in River Douro Estuary, Portugal. Aquatic Toxicology 71: $39-48$.

Fodrie, F.J. and Herzka, S.Z. 2008. Tracking juvenile fish movement and nursery contribution within arid coastal embayments via otolith microchemistry. Marine Ecology Progress Series 361: 253-265.

Fodrie, F.J. and Herzka, S.Z. 2013. A comparison of otolith geochemistry and stable isotope markers to track fish movement: describing estuarine ingress by larval and postlarval halibut. Estuaries and Coasts 6: 209-217.

Fodrie, F.J. and Mendoza, G. 2006. Availability, usage and expected contribution of potential nursery habitats for the California halibut. Estuarine, Coastal and Shelf Science 68: 149-164.

Fodrie, F.J., Levin, L.A., Lucas, A.J. 2009. Use of population fitness to evaluate the nursery function of juvenile habitats. Marine Ecology Progress Series 385: 39-49.

Fonseca, V.F., Frana, S., Serafim, A., Company, R., Lopes, B., Bebianno, M.J., Cabral, H.N. 2011a. Multi-biomarker responses to estuarine habitat contamination in three fish species: Dicentrarchus labrax, Solea senegalensis and Pomatoschistus microps. Aquatic Toxicology, 102: 216-227.

Fonseca, V.F., Frana, S., Vasoncelos, R.P., Serafim, A., Company, R., Lopes, B., Bebianno, M.J., Cabral, H.N. 2011b. Short-term variability of multiple biomarker response in fish from estuaries: influence of environmental dynamics. Marine Environmental Research 72: 172-178.

Forrester, G.E., Fredericks, B.I., Gerdeman, D., Evans, B., Steele, M.A., Zayed, K., Schweitzer, L.E., Suffet, I.H., Vance, R.R. and Ambrose, R.F. 2003. Growth of estuarine fish is associated with the combined concentration of sediment contaminants and shows no adaptation or acclimation to past conditions. Marine Environmental Research 56: 423442.

Forrester, G.E. and Swearer, S.E. 2002. Trace elements in otoliths indicate the use of open-coast versus bay nursery habitats by juvenile California halibut. Marine Ecology Progress Series 241: 201-213. 
Greenstein, D., Bay, S., Jacobe, M., Barton, C., Sakamoto, K., Young, D., Ritter, K. and Schiff, K. 2013. Regional assessment of marine and estuarine sediment toxicity in Southern California, USA. Environmental Monitoring and Assessment 185: 2055-2065.

Johnson, M.R., Williams, S..L., Lieberman, C.H. and Solbak, A. 2003. Changes in the abundance of the seagrasses Zostera marina (eelgrass) and Ruppia maritima (widgeongrass) in San Diego, California, following an El Niæo event. Estuaries 26: 106 115 .

Kayhaniana, M., Stransky, C., Bay S., Laud, S.L. and Stenstromd, M.K. 2008. Toxicity of urban highway runoff with respect to storm duration. Science of the Total Environment 389: 386-406.

Kramer, S. 1991. Growth, mortality, and movements of juvenile California halibut Paralichthys californicus in shallow coastal and bay habitats of San Diego County, California. U.S. Fishery Bulletin 89: 195-207.

Kopecka-Pilarczyk, J. 2013. Comparison of selected biomarkers in flounder (Platichthys flesus L.) from the Douro (Portugal) and Vistula (Poland) River estuaries. Marine Pollution Bulletin 73: 70-77.

Lao, W., Tiefenthaler, L., Greenstein, D.J., Maruya, K.A., Bay, S.M., Ritter, K. and Schiff, K. 2012. Pyrethroids in Southern California Coastal Sediments. Environmental Toxicology and Chemistry 31: 1649-1656.

Largier, J.L., Hollibaugh, J.T. and Smith, S.V. 1997. Seasonally hypersaline estuaries in Mediterranean-climate regions. Estuarine, Coastal and Shelf Science 45: 789-797.

Livingstone, D.R. 1998. The fate of organic xenobiotics in aquatic ecosystems: quantitative and qualitative differences in biotransformation by invertebrates and fish. Comparative Biochemistry and Physiology 120: 43-49.

Long, E.R., MacDonald, D.D., Smith, S.L. and Calder, F.D. 1995. Incidence of adverse biological effects within ranges of chemical concentrations in marine and estuarine sediments. Environmental Management 19: 81-97.

Lpez -Rasgado, F.J. and Herzka, S.Z. 2009. Assessment of habitat quality for juvenile California halibut (Paralichthys californicus) in a seasonally arid estuary. Fishery Bulletin 107: 343-358.

Lu, G.H., Qi, P.D. and Chen, W. 2013. Integrated biomarker responses of Carassius auratus exposed to BDE-47, BDE-99 and their mixtures. International Journal of Environmental Research 7: 807-816.

Martnez - 'lvarez, R.M., Morales, A.E. and Sanz, A. 2005. An tioxidant defenses in fish: biotic and abiotic factors. Reviews in Fish Biology and Fisheries 15: 75-88.

Maruya, K.A., Vidal-Dorsch, D.E., Bay, S.M., Kwon, J.W., Xia, K. and Armbrust, K.L. 2012. Organic contaminants of emerging concern in sediments and flatfish collected near outfalls discharging treated wastewater effluent to the Southern California Bight. Environmental Toxicology and Chemistry 31: 2683-2688

Minghetti, M., Leaver, M.J., CarpenE, E. and George, S.G. 2008. Copper transporter 1, metallothionein and glutathione reductase genes are differentially expressed in tissues of sea bream (Sparus aurata) after exposure to dietary or waterborne copper. Comparative Biochemistry and Physiology 147: 450-459. 
Nautilus Environmental. 2006. Mission Bay watershed evaluation: chemistry and toxicity. Toxicity and Chemistry Year End Summary. 41 pp.

Pereira, P., de Pablo, H., Pacheco, M. and Vale, C. 2010a. The relevance of temporal and organ specific factors on metals accumulation and biochemical effects in feral fish (Liza aurata) under a moderate contamination scenario. Ecotoxicology and Environmental Safety 73: 805-816.

Pereira, P., de Pablo, H., Vale, C. and Pacheco, M. 2010b. Combined use of environmental data and biomarkers in fish (Liza aurata) inhabiting a eutrophic and metalcontaminated coastal system - Gills reflect environmental contamination. Marine Environmental Research 69: 53-62.

Reyes, J.A., Vidal-Dorsch, D.E., Schlenk, D., Bay, S.M., Armstrong, J.L., Gully, J.R., Cash, C., Baker, M., Stebbins, T.D., Hardman, G. and Kelley, K.M. 2012. Evaluation of reproductive endocrine status in hornyhead turbot sampled from Southern California's urbanized coastal environments. Environmental Toxicology and Chemistry 31: 26892700 .

Roy, L.A., Armstrong, J.L., Sakamoto, K., Steinert, S., Perkins, E., Lomax, D.P., Johnson, L.L. and Schlenk, D. 2003. The relationships of biochemical endpoints to histopathology and the population metrics in feral flatfish species collected near the municipal wastewater outfall of Orange County, California, USA. Environmental Toxicology and Chemisty 22: 1309-1317.

Roy, L.A., Steinert, S., Bay, S.M., Greenstein, D., Sapozhnikova, Y., Bawardi, O., Leifer, I. and Schlenk, D. 2003. Biochemical effects of petroleum exposure in hornyhead turbot (Pleuronichthys verticalis) exposed to a gradient of sediments collected from a natural petroleum seep in CA, USA. Aquatic Toxicology 65: 159-169.

Schiff, K., Gossett, R, Ritter, K., Tiefenthaler, L., Dodder, N., Lao, W., and Maruya, K. 2011. Southern California Bight 2008 Regional Monitoring Program: III. Sediment Chemistry. Southern California Coastal Water Research Project, Costa Mesa, CA. 64 pp.

Seruto, C., Sapozhinikova, Y. and Schlenk, D. 2005. Evaluation of the relationships between biochemical endpoints of PAH exposure and physiological endpoints of reproduction in male California Halibut (Paralichthys californicus) exposed to sediments from a natural oil seep. Marine Environmental Research 60: 454-465.

SolØ, M., Rodrguez, S., Papiol, V., Maynou, F. and Cartes, J.E. Xenobiotic metabolism markers in marine fish with different trophic strategies and their relationship to ecological variables. Comparative Biochemistry and Physiology 149: 83-89.

SolØ, M., Ant, M., Baena, M., Carrasson, M., Cartes, J.E. and Maynou, F. 2010. Hepatic biomarkers of xenobiotic metabolism in eighteen marine fish from NW Mediterranean shelf and slope waters in relation to some of their biological and ecological variables. Marine Environmental Research 70: 181-188.

Van der Oost, R., Beyer, J., Vermeulen, N. 2003. Fish bioaccumulation and biomarkers in environmental risk assessment: a review. Environmental Toxicology and Pharmacology 13: 57-149.

Whyte, J.J., Jung, R.E., Schmitt, C.J and Tillitt, D.E. 2000. Ethoxyresorufin-O-deethylase (EROD) activity in fish as a biomarker of chemical exposure. Critical Reviews in Toxicology 30: 347-570. 


\section{Chapter 2.0 - Distribution of Sediment Contaminants in Mission Bay, San Diego, California}

\section{1 - Introduction}

Mission Bay is an estuary located in San Diego, California, USA. It is situated near urban areas and receives fresh water input from these urbanized watersheds, primarily during the rainy season of November through April (Elliott and Kaufmann 2007). Some areas of Mission Bay are relatively disconnected from tidal flushing as well as receiving little freshwater influence, resulting in seasonally hypersaline conditions (Largier et al. 1997). There are no point sources of pollution into the bay, but three creeks and 100 storm drains bring in urban runoff (Stransky 1999), which has been shown to be a significant source of non-point pollution in highly urbanized areas of Southern California (Davis et al. 2001, Kayhanian et al. 2008, Brown et al. 2013). In addition, there are several boat basins that shelter both pleasure and commercial boats that cruise within the bay and out to sea through the channel that remains permanently open to the sea.

Previous work in Mission Bay has shown that areas in the back of the bay, near the creek mouths, are most susceptible to degraded sediment quality. Stransky (1999) found that sediments collected from the back bay and boat basins in Mission Bay had chemical concentrations that were above the EPA ERL (Effects Range Low) benchmark for arsenic, copper, lead, mercury, nickel, zinc, DDT, DDE and PCBs, while chlordane was found at a concentration above the ERM (Effects Range Median) benchmark. Similar patterns of contamination also were found in quarterly sampling of Mission Bay between November 2001 and November 2002 (Kaufmann et al. 2004) and May 2004 and May 2005 (Kaufmann et al. 2006). More recently, the back of Mission Bay has been sampled as part of the Southern California Bight Regional Monitoring Program (Bight 0'8), which identified high levels of pyrethroids and moderate levels of copper relative to other embayments (Schiff et al. 2011, Lao et al. 2012, Dodder et al. 2012). These studies have found that the inner reaches of Mission Bay display sediment contaminant concentrations that are comparable to areas within the more heavily polluted San Diego Bay. However, a comprehensive survey of various chemical 
contaminants, including both inorganic (metals) and organic contaminants (pesticides, PAH's, etc.), has not been conducted across Mission Bay.

There is a need for additional sampling in Mission Bay, especially when considering current use pesticides and contaminants of emerging concern (CECs) such as pyrethroids, fipronil and its degredates, and polybrominated diphenyl ethers (PBDEs). Synthetic pyrethroids are a highly prevalent group of current use pesticides used in agricultural and residential formulations. Their use in California occurs throughout the state and have been observed to cause toxicity to non-target aquatic organisms such as the amphipod Hyalella azteca in sediments from an urban creek in Los Angeles (Lao et al. 2010, Lao et al. 2012), surface waters and sediments in Orange County (Ensminger et al. 2013) sediment and surface water in residential watersheds in Sacramento (Weston et al. 2005, Weston et al. 2009, Weston et al. 2012, Ensminger et al. 2013) and surface waters in San Francisco Bay (Ensminger et al. 2013). Bifenthrin is one of the most commonly measured pyrethroids in sediments and surface waters (Weston et al. 2012, Ensminger et al. 2013), which may be due to the dominance in residential formulations and the multiple applications (like pellets and sprays) that are available (Weston et al. 2012). Bifenthrin has been shown to cause behavioral changes, tissue damage, and endocrine disruption in fishes (Velisek et al. 2009, Beggel et al. 2011, Schlenk et al. 2012). Fipronil is a phenylpyrazole insecticide that is effective against insects that are resistant to many other insecticides, and commonly applied by pest management professionals for structural pest control for insects such as termites, ants and cockroaches (Ensminger et al. 2013). In aquatic environments it is challenging to monitor due to it's multiple degradation products: in sediments and surface waters fipronil may undergo photolysis to desulfinyl fipronil, oxidation to fipronil sulfone, or reduction to fipronil sulfide (Gunasekara and Troung 2007). It has been detected in southern and central California watersheds (Ensminger et al. 2013), but toxicity in fish has only been described for freshwater fish species (Gunasekara and Troung 2007, Lao et al. 2010, Baird et al. 2013). PBDEs are flame retardants found in a variety of products such as plastics, foams and textiles. Investigations in the Southern 
California Bight (SCB) found that the highest concentrations were measured near the mouths of urban rivers, suggesting that urban runoff is the primary source of these compounds to the environment (Dodder et al. 2012). Given the tendency for these CECs to bioaccumulate in higher-trophic-level organisms, more focus on their prevalence and toxicity is needed in Southern California (Dodder et al. 2012, Baird et al. 2013).

Rain events are a very important factor in the delivery metals and organic compounds to receiving waters, especially in urban watersheds with large areas of impervious surfaces (Davis et al. 2001, Amweg et al. 2006, Brown et al. 2013, Ensminger et al. 2013). These compounds enter the receiving water in both dissolved and particulate bound forms (Lee et al. 2004). In urban areas, over 90\% of the sediments entering receiving waters are less than $30 \mu \mathrm{m}$ in diameter ( $\mathrm{Li}$ et al. 2005), which is the fraction of sediments that carries the highest percentage of metals (Brown et al. 2013). In Sacramento, it was shown that one day of moderate rainfall or three hours of intense rainfall can deliver as much bifenthrin to an urban river as six months of dry weather irrigation runoff (Weston et al. 2009). The "first flush" of these constituents in urban watersheds after long dry periods has been shown in Southern California (Yoon and Stein 2008), and it has been shown in Los Angeles that runoff from highways had $40 \%$ of the total particulates carried in the first $20 \%$ of runoff volume ( $\mathrm{Li}$ et al. 2005).

The purpose of this investigation was to determine the concentrations of a suite of contaminants in different regions of Mission Bay and to examine the distribution of contaminants among different habitat types. The median grain size and percent fine fraction as well as the concentrations of metals $(\mathrm{Cu}, \mathrm{Pb}, \mathrm{Zn})$, PAHs, pyrethroids, fipronil, and PBDEs were measured at six different sites that represent a gradient in sediment type and proximity to freshwater inputs from the front to the back bay. These results were compared to previous work to examine long-term trends and identify potential sites of concern for future research and monitoring efforts.

\section{2 - Methods}




\subsection{1 - Site Description}

Sediments were collected at six sites in Mission Bay over the course of one annual cycle (June 2012 through May 2013; Fig. 2.1). Some additional sediment samples were obtained in the spring (March) of 2014. Two sites were sampled in the front bay (Mariner's Cove, Ventura Cove), two in the mid-bay (Fiesta Bay, Crown Point), and two in the back bay (near the mouths of Cudahy Creek and Tecolote Creek).

\section{Mariner's Cove}

The closest site to the entrance of the bay, this cove is directly across from Quivira Basin and is formed by the arm of Mission Point Park (Fig 2.2). An eelgrass bed is present in the south and northeast portions of the cove and extends from the shore at low tide out to the opening of the cove, which has a depth of around $6 \mathrm{~m}$ MLLW. Sediment samples were taken off the beach at the south end of the cove, while channel samples were taken between the two points that create the entrance to the cove. Additional samples in 2014 were taken inside the cove, near the lifeguard pier in Quivira Basin, and in the middle of the channel leading out of Mission Bay.

\section{$\underline{\text { Ventura Cove }}$}

This site is located directly to the northwest of the West Mission Bay Drive bridge, across from Vacation Island (Fig 2.3). This beach has a steep slope with eelgrass beds emerging at the edge during low tide. Beach samples were collected in front of the eelgrass beds. Channel samples were collected just outside the cove in the adjacent channel, which has a depth of around $5 \mathrm{~m}$ MLLW. Additional samples in 2014 were collected at the same channel site, as well as near the Dana Landing fuel dock.

\section{Fiesta Bay}

This site is located on the northwest side of Fiesta Island, on the beach due east of Beacon Island in the middle of Fiesta Bay (Fig. 2.4). This beach sees extensive day/RV usage by humans and their pets as there is a dog park on the southwest 
side of the island. There are also several annual events on the island (full/half marathons, summer camps, and large sports tournaments), which cause increased vehicular traffic, leave trash on the island, and results in increased usage of the beach. Eelgrass beds extend the length of the beach, and at times are exposed by the low tide. Beach sediment samples were collected on the beach due east of Beacon Island, while channel samples were taken in the channel that separates Fiesta Island from Beacon Island at a depth of around $5 \mathrm{~m}$ MLLW. Additional samples in 2014 were taken slightly north of Beacon Island in a depth of around 5 m MLLW.

\section{Crown Point}

This site is located on the northeast side of Crown Point, directly south of the Kendall-Frost/Northern Wildlife Reserves boundary (Fig. 2.5). The sampling area includes swim beaches that are especially popular in the summer months, and dirt/paved parking lots that support large events in the park. The eelgrass is close to shore near the reserve boundary and also behind the large, sandy swim areas where the shore slopes into deeper water. Beach sediments were collected near the reserve boundary, while channel samples were collected due east in a depth of around $4 \mathrm{~m}$ MLLW. Additional samples in 2014 were taken near Rose Creek, both near the mouth where it enters the bay and upstream where the creek makes its way through Pacific Beach.

\section{Cudahy Creek}

Cudahy Creek is located to the east of the northern end of Fiesta Island (Fig. 2.6). The site has eelgrass beds off the Fiesta Island side and between the rocky point extending all the way to the creek mouth to the southeast. Beach sediments were collected on the mainland side, while channel samples were collected in the channel due west of the creek mouth in a depth of about $4 \mathrm{~m}$ MLLW. Additional samples in 2014 were collected in the channel between Fiesta Island and the Mission Bay Park Visitor Center.

\section{$\underline{\text { Tecolote Creek }}$}


Tecolote Creek is located just to the north of the causeway that provides road access to Fiesta Island (Fig. 2.7). Eelgrass beds are all along the shore in the basin, and the slope of the beach is moderate with evidence of stingray feeding pits commonly observed on the shore during low tide. Beach sediments were collected on Fiesta Island, opposite the creek mouth. Basin sediments were collected in the basin between the beach and the creek mouth in a depth of about 4 $\mathrm{m}$ MLLW, and channel sediments were collected in the area slightly north of the basin in a depth of about $4 \mathrm{~m}$ MLLW. Additional samples in 2014 were collected near the channel sampling location as well as off the beach close to the creek mouth.

\subsection{2 - Field Sampling}

At each site prior to sampling, temperature and salinity at the surface and at the bottom was measured with a YSI multimeter. At beach sites, bottom temperature and salinity was measured at $1 \mathrm{~m}$ depth.

Sediments were collected from all beach sites during all seasons in 20122013, as well as from some channel sites during various seasons. For beach sites, a box core was deployed on the shallow side of the eel grass beds in about $1 \mathrm{~m}$ MLLW, since the sea floor drops off considerably within and behind the eel grass. Channel and basin samples were also collected using a $30 \times 30 \mathrm{~cm}$ box core, and the box core was cleaned between sites using DI water and brushes to remove any remaining sediments. The box cores were then sub-sampled to a depth of $3-5 \mathrm{~cm}$ using two teflon sub-cores with a diameter of $2.7 \mathrm{~cm}$ and stored in a cooler on ice for transport back to the lab. These samples were described on site for penetration depth, color, smell, and presence/absence of eelgrass in the sample.

For pyrethroid, fipronil and its degredates, and PBDE analysis, bulk sediment samples collected in February and March of 2013 were analyzed. Box cores were deployed, and the top 2-5 cm of the sediment was collected and placed into precleaned glass containers, which were placed on ice in a cooler for transport back

to the lab. These samples were described on site for color, smell, and presence/absence of eelgrass in the sample. Samples collected in 2014 also used 
this bulk sediment method in order to obtain more sample volume compared to the core samples.

\subsection{3 - Preparation of Sediments for Analysis}

Sediment samples were brought back to the lab and stored in a $-20^{\circ} \mathrm{C}$ freezer. Prior to analysis, sub-cores were taken out of the freezer and the top $2 \mathrm{~cm}$ was removed and placed in a plastic whirl-pak bag to thaw. Each sample was homogenized by stirring and separated in half. One half was put back in the $20^{\circ} \mathrm{C}$ freezer as a 'wet' sample, which was used for grain size and $\mathrm{PAH}$ analysis. The other half was freeze dried using a lyophilizer before being placed back in the $-20^{\circ} \mathrm{C}$ freezer as a 'dry' sample. These freeze dried samples were used for metals analysis. PAH analysis was conducted on the wet samples since the freeze drying process could remove the more volatile PAHs. Results were corrected for the water content in each sample. The freeze dried samples were used for metal analysis so that concentrations were on a dry weight basis.

Bulk sediments were homogenized, and sub-samples were freeze-dried before being placed back in the $-20^{\circ} \mathrm{C}$ freezer.

\subsection{4. - Grain Size Analysis}

Grain size distribution was analyzed using a Beckman Coulter LS 200 Laser Particle Sorter (LPS) on wet sediments. Sediments were prepared by first allowing them to thaw, then placing a sub-sample in a beaker with a dilute $5 \%$ detergent solution to disaggregate fine particles before performing the analysis. Each sample was analyzed in triplicate, and the mean of these three analyses was calculated. Statistics were calculated for median grain size in $\mu \mathrm{m}$ and percent fine fraction $(<63 \mu \mathrm{m})$.

\subsection{5 - Metals Analysis}

Analysis of acid-assisted soluble metal content was performed using EPA method 3051A. $0.5 \mathrm{~g}$ freeze dried sediments were weighed into an acid washed, triple de-ionized (DI) water rinsed Teflon reaction vessel equipped with a

pressure release mechanism. $9 \mathrm{~mL}$ of concentrated trace metal grade nitric acid 
$(65 \%)$ was added to the sample under a fume hood and allowed to react for 10 minutes. The samples were then heated in a closed Milestone Ethos EZ Microwave Digestion System for 10 minutes. The microwave was heated to 175 ${ }^{\circ} \mathrm{C}$ for 5.5 minutes and then held at $175{ }^{\circ} \mathrm{C}$ for 4.5 minutes. The samples were then allowed to cool in the reaction vessel before being transferred to a labeled 50 $\mathrm{mL}$ Teflon falcon tube. The samples were diluted using Milli-Q water (at least 18.3 $\mathrm{M} \Omega-\mathrm{cm}$ ) so that the final solution was $<10 \%$ nitric acid in order to reduce matrix interference during analysis. One field duplicate and method blank (which contained no sediment, just nitric acid) was prepared for every 8 samples run through the digestion protocol. The accuracy of the method was measured by microwave extraction of NIST SRM 2702 (inorganics in marine sediment) and comparing the measured values with certified values by calculating the relative percent difference (RPD) using the calculation:

$\% \mathrm{RPD}=100 \times\left(\left|\mathrm{R}_{1}-\mathrm{R}_{\mathrm{s}}\right| / \mathrm{R}\right)$

Where:

$\left|R_{1}-R_{s}\right|=$ absolute difference of reported result minus concentration in the standard $\mathrm{R}=$ concentration in the standard

RPD percentages were targeted to be close to $5 \%$ and were not accepted when above $10 \%$.

Replicate samples were analyzed for precision by calculating the relative standard deviation (RSD) and relative percent difference (RPD) by using the formulas below:

Where :

$$
\% \operatorname{RSD}=100 \times(\sigma / \mathrm{R})
$$

$\sigma=$ standard deviation of replicate analysis

$\mathrm{R}=$ arithmetic mean of the replicates

RSD percentages were targeted to be close to $5 \%$ and were not accepted when above 10\%. Blanks were usually close to zero and their RSD and RPD percentages were not accepted when above 10\%. Between each batch of samples, microwave vessels were soaked in $10 \%$ nitric acid overnight to prevent cross contamination between samples. 
The digested samples were analyzed by EnviroMatrix Analytical, Inc., which is an accredited lab in San Diego, CA in order to follow QA/QC protocols for the method. Samples were filtered as needed to prevent sediment from interfering with analysis and run for copper, lead and zinc using an ICP-MS.

\subsection{6 - Organics: PAHs, Pyrethroids, Fipronil and PBDEs}

Analysis of core samples for 13 PAHs from Summer 2012 to Spring 2013 was conducted using a QuEChERS (Quick, Easy, Cheap, Effective, Rugged, Safe) extraction (Pule et al. 2012). Unbuffered salt packets (4 g MgSO $4,1 \mathrm{~g}$ $\mathrm{NaCl}$ ) and polypropylene centrifuge tubes from Restek were used with ACS grade acetonitrile to perform the extraction. 9,10-Diphenylanthracene was used as an internal standard for recovery calculation. 2-3 g of sediment was added to a $50 \mathrm{ml}$ centrifuge tube with $5 \mathrm{~mL}$ of acetonitrile and $100 \mu \mathrm{L}$ of $10 \mu \mathrm{g} / \mathrm{mL} 9,10-$ Diphenylanthracene. The sample was then shaken by hand for one minute. The salt packet was added to the centrifuge tube and was shaken by hand for one minute. The sample was then centrifuged at room temperature at 3,000 rpm for 5 minutes. The supernatant was extracted and put in glass vials. Vials were stored at $-20 \mathrm{C}$ until analysis.

QuEChERS extractions were analyzed by high performance liquid chromatography (HPLC) using fluorescence detection. Samples were compared to a 5-point calibration curve using EPA method $525 \mathrm{mix} \mathrm{B}$ as a standard. For each sample, $5 \mu \mathrm{L}$ was injected in the machine onto a $150 \mathrm{~mm} \times 4.6 \mathrm{~mm}$ Restek Pinnacle II PAH column (particle size $4 \mu \mathrm{m}$, pore size $110 \AA$ ) at 30C using acetonitrile and water as a mobile phase. The ratio of water:acetonitrile over the course of the 24 minute analysis was as follows: $60: 40$ at $0 \mathrm{~min}, 40: 60$ at $6.5 \mathrm{~min}, 30: 70$ at $8 \mathrm{~min}, 0: 100$ at $12 \mathrm{~min}, 60: 40$ at $15.5 \mathrm{~min}$. The excitation/emission wavelengths over the course of the analysis was as follows: $270 / 330$ at $0 \mathrm{~min}, 250 / 370$ at $8.7 \mathrm{~min}, 330 / 430$ at $10.5 \mathrm{~min}, 270 / 390$ at $11.6 \mathrm{~min}, 290 / 430$ at $13.5 \mathrm{~min}, 270 / 330$ at $16.7 \mathrm{~min}$. The wavelength change at 16.7 minutes, designed to identify indeno[1,2,3cd]pyrene, failed to produce acceptable peak shape, and therefore this peak 
was not quantified in any of the assays. The standard 5-point curve for the internal recovery standard 9,10-Diphenylanthracene was done separate of the analysis of samples to eliminate contamination concerns. Results were corrected for water content of the sediment samples.

Analysis of bulk sediment samples for 26 PAHs from spring 2013 for PAHs, pyrethroids, fipronil and its degredates, and PBDEs was carried out by the Southern California Coastal Water Research Project (SCCWRP) in Costa Mesa, CA. Prior to analysis, percent total organic carbon was analyzed for each sample. The limit of quantification for all analyses carried out by SCCWRP are listed in Table 2.1. The PAH extraction and analysis was more complicated and expensive, so only one season was selected for analysis.

Standards for calibration included PAHs, OCPs, PBDEs, fipronils (including fipronil, fipronil desulfinyl, fipronil sulfide, fipronil sulfone), and pyrethroids (bifenthrin, permethrin, cypermethrin, esfenvalerate, cyfluthrin, deltamethrin, lamba-cyhalothrin and fenpropathrin). All glassware and sodium sulfate were baked at $500{ }^{\circ} \mathrm{C}$ for $4 \mathrm{~h}$ before use.

Freeze dried sediment sample (1-5 g) was packed into a $34 \mathrm{~mL}$ stainless steel cell and spiked with 4,4'-dibromooctafluorobiphenyl (DBOFB) and PCB208 as internal standards. The samples were extracted with dichloromethane (DCM, HR-GC grade) for four sequential extraction cycles at 100C and 1500 psi followed by purging (100 sec) with ultra-high purity using a Dionex Accelerated Solvent Extraction (ASE) 300 system. The extracts were concentrated on a TurboVap 500 evaporator, and solvent was exchanged into hexane (HR-GC grade). The sediment extracts were kept in dark overnight at room temperature after adding activated copper powder (20-30 mesh) to remove element sulfur. The sediment extracts were cleaned up on $30 \mathrm{~cm}$ length $10 \mathrm{~mm}$ i.d. glass column packed with $10 \mathrm{~g}$ of $6 \%$ water deactivated Florisil (60-100 mesh). After loading sample, the fractions of the first $60 \mathrm{~mL}$ hexane/ethyl ether $(7: 3, \mathrm{v} / \mathrm{v})$ was collected. The final extract volume was reduced under a gentle nitrogen stream to less than $0.5 \mathrm{~mL}$. After adding internal standard, the volume of the extract was adjusted to $0.5 \mathrm{~mL}$ and stored at $-20 \mathrm{C}$ until analysis. 
The extracts were analyzed on two instrumental systems of Agilent 7890 gas chromatograph (GC) coupled to a 5975C quadrupole mass-selective detector (MSD) operated in electron impact (EI,70 eV) and negative chemical ionization (NCI) modes, respectively. The PAHs were analyzed on the EI-MS system, pyrethroids, PBDEs, fipronil and its three degradates were analyzed on the NCIMS system. The carrier gas was ultrahigh purity helium with a constant flow rate of $1 \mathrm{ml} / \mathrm{min}$ in the EI mode, and $1.9 \mathrm{ml} / \mathrm{min}$ in the NCI mode using methane as reagent gas at $40 \%$ flow rate. The sample $(1 \mu \mathrm{L})$ was injected into DB-XLB column $(30 \mathrm{~m} \quad 0.25 \mathrm{~mm} \quad 0.25 \mu \mathrm{m})$ through a split/splitless inlet operated isothermally at $300 \mathrm{oC}$ in 1 -min splitless mode. The oven temperature in the EI mode was programmed from $80 \mathrm{C}$ held for $1 \mathrm{~min}$ to $190 \mathrm{C}$ at $5 \mathrm{C} / \mathrm{min}$, to $260 \mathrm{C}$ at $4 \mathrm{C} / \mathrm{min}$, to $290 \mathrm{C}$ at $20 \mathrm{C} / \mathrm{min}$, and to $300 \mathrm{C}$ at $50 \mathrm{C} / \mathrm{min}$ held for $20 \mathrm{~min}$. The transfer line, ion source and quadrupole of MSD in the EI mode were maintained at 280,230,150 C, respectively. The oven temperature in the NCI mode was programmed from $90 \mathrm{C}$ held for $1 \mathrm{~min}$ to $150 \mathrm{C}$ at $5 \mathrm{C} / \mathrm{min}$, to $260 \mathrm{C}$ at $3 \mathrm{C} / \mathrm{min}$, and to $320 \mathrm{C}$ at $20 \mathrm{C} / \mathrm{min}$ held for $5 \mathrm{~min}$. The transfer line, ion source and quadrupole of MSD in the NCI mode were maintained at 280, 150, $150 \mathrm{C}$, respectively. Selected ion monitoring (SI M) mode was used to analyze all the samples. Five-point internal standard calibration curves were used to quantify target compounds.

\subsection{7 - Statistical Analysis}

Sediment parameters and contaminant concentrations were tested for correlations using Pearson product-moment correlation scores. Since grain size and percent fine fraction was determined for each site and each season, nonparametric Kruskall-Wallis tests with post hoc Mann-Whitney U tests were conducted to look for differences among both seasons and sites.

Multivariate statistical analysis for metal and PAH concentrations from core sediment samples was run on PRIMER-E software. Sites had beach and channel samples combined to make a site composite for analysis. 
The first test used was principal coordinates analysis (PCO). PCO is an ordination operation based off of a resemblance matrix that is calculated using Euclidean distances. Unlike non-metric multidimensional scaling (MDS) which uses only rank-orders to create an ordination, PCO uses the actual dissimilarity of samples to create the ordination. The goal of the ordination is to reduce the dimensionality of the data cloud in order to allow the most salient patterns and structures to be observed. PCO will also give a closer reflection of the resemblance values actually used in the partitioning methods like PERMANOVA.

The second test used was PERMANOVA. This is a routine for testing simultaneous response of one or more variables to one or more factors in an analysis of variance experimental design on the basis of any resemblance measure, using permutation methods. It was used to separate out significant differences amongst sites and seasons for the biomarker datasets. Once significance was determined for sites or seasons, pairwise comparison was performed to try to establish groups of sites/seasons that were most similar to one another.

The third test was canonical analysis of principal coordinates (CAP). The purpose of CAP is to find axes through the multivariate cloud of points that either a) are the best at discriminating among a priori groups or b) have the strongest correlation with some other set of variables. In some cases, there are known differences among some pre-defined groups (such as from significant result of PERMANOVA analysis), and the goal is to characterize those differences. CAP uses the central question: is there an axis through the multivariate cloud of points that is best at separating groups? This axis can be fundamentally different from the direction of greatest total variation across the data cloud, which sometimes makes these groups hard to see on PCA, MDS or PCO plot. The results of the model are cross-validated by pulling out one sample at a time and checking the ability of the model to correctly classify the samples into its appropriate group. This gives specific information about how distinct the groups are and how well the PCO axes discriminate among the groups. This is the best way to test the validity and utility of the CAP model. 


\section{3 - Results}

\subsection{1 - Spatial Variation}

Median grain size and percent fine fraction showed significant differences among beach sites. Mariner's Cove and Ventura Cove had the highest median grain size, while Cudahy Creek and Tecolote Creek had the lowest (Fig. 2.8). Fiesta Bay and Crown Point were in the middle, with Crown Point having slightly higher grain size over all seasons. With limited samples taken from channel and basin sites, there was no significant difference among these sites, although similar patterns were observed at Mariner's Cove, Ventura Cove and Fiesta Bay having higher median grain sizes compared to the three sites near the back of the bay (Fig. 2.9).

Percent fine fraction showed an inverse pattern to grain size at the beach sites. Statistically, Ventura Cove had the lowest percent fine fraction, followed by Fiesta Bay and Mariner's Cove (Fig. 2.10). Cudahy Creek and Tecolote Creek had the highest percent fine fraction, followed by Crown Point. With limited samples taken from channel and basin sites, there was no significant difference among these sites (Fig. 2.11). Tecolote Creek, Cudahy Creek and Crown Point all had similarly high percent fine sediments. The front bay was variable, but Ventura Cove had the lowest percent fine fraction concentrations.

Pyrethroids, fipronil and its degredates, PBDEs and PAH concentrations were determined for samples from spring of 2013 (Table 2.2, Fig. 2.12). Sediments from the Tecolote Creek Basin showed concentrations of pyrethroids, total fipronils and PBDEs that were almost a full order of magnitude higher than samples collected from the beach and channel at the same site. In general, channel samples displayed higher concentrations of contaminants compared to beach samples except for Cudahy Creek, where beach samples contained much higher concentrations of PAHs compared to channel samples. PBDEs were variable between sampling locations at several sites; beach samples had slightly higher concentrations than channel samples. Mariner's Cove beach and Ventura Cove beach samples did not contain any of the compounds for which they were 
tested, while Fiesta Bay beach sediments only showed low levels of PAHs compared to samples from the back bay.

Fipronil sulfone was found at the highest concentrations, and fipronil desulfinyl was found at the most sites (Table 2.3). All three degradates of fipronil were detected in the bay, but some were below the limit of quantification (LOQ) and were excluded from the total. For pyrethroids, bifenthrin and permethrin made up the majority of the pyrethroids detected (Table 2.3). Bifenthrin was detected at the most sites within the bay, and was the only one detected in beach sediments from Fiesta Bay, although below the LOQ.

Concentrations of 14 PBDE species were measured in Mission Bay sediments (Table 2.4). Congeners 47 and 99 were most prevalent in the bay in terms of percentage of the total, and were even detected at the beach at Mariner's Cove, Ventura Cove and Fiesta Bay although below the LOQ for the method at all three locations.

The 26 PAHs from the bulk sediments were separated into high- and lowmolecular weight compounds as well by the number of rings they contain (Table 2.5). Low-molecular-weight, 2- and 3-ring PAHs are typically from natural sources, while high-molecular-weight, multi-ring PAHs are from anthropogenic sources (e.g. combustion engines) and tend to show higher toxicity in fishes (Seruto 2005, Fonseca et al. 2011a). High-molecular-weight PAHs made up the vast majority of total PAHs from beach, channel and basin samples. This can be seen in the breakdown by ring structure, with 4-, 5-, and 6-ring compounds making up the highest fractions of the totals. 2- and 3-ring compounds made up a very small percentage of the totals, although 3-ring compounds were more prevalent than 2-ring PAHs.

Core sediment samples were measured for 13 PAHs at the different sites and habitats within the bay (Table 2.6). Analysis of the internal standard diphenylanthracene showed that the average recovery for the method was $89.1 \%$. Concentrations of PAHs were higher in the channel and basin samples compared to the beaches (Fig. 2.13-2.14, Table 2.7-2.12). One exception was at Cudahy Creek, where the PAH concentrations on the beach were higher than in the 
channel for two of the three seasons sampled (Table 2.6). The other exception was in Rose Creek upstream of the mouth, where the sample taken from the middle of the creek bed had less than a third of the concentration of PAHs as the sample taken from the beach (Table 2.6, Figure 2.5). The beaches Mariners Cove, Ventura Cove and Fiesta Bay overall had the lowest concentrations of PAHs, although seasonally which one was lowest fluctuated (Fig. 2.13). Crown Point beach was slightly more elevated than the other front and middle bay sites. Cudahy Creek and Tecolote Creek beaches had the highest concentrations of PAHs compared to the other beach sites. The channel sample from Ventura Cove had the lowest concentration of PAHs (78 ppb, Fig. 2.14). Fiesta Bay channel had the second lowest average concentration of PAHs (95.53 ppb), but Ventura Cove and Fiesta Bay channels were only sampled once compared to the other sites which had multiple samples taken. Mariners Cove channel and the Rose Creek bed had similar elevated PAH concentrations (up to $152.17 \mathrm{ppb}$ and $123.81 \mathrm{ppb}$, respectively). Crown Point channel and the Dana Landing fuel dock had similar levels of PAH concentrations (up to $319.27 \mathrm{ppb}$ and $242 \mathrm{ppb}$, respectively), which were higher than Mariner's Cove and the Rose Creek bed. The Rose Creek bank had similar PAH concentrations to those found in the Cudahy Creek channel (344.20 ppb and up to $443.85 \mathrm{ppb}$, respectively). The highest measured concentrations of PAHs were at the Tecolote Creek channel (588.48 ppb), Quivira Basin (484.44 ppb) and the Tecolote Creek basin (1111.89 ppb), with the Tecolote Creek basin sample having double the concentration as the samples nearby in the channel.

Copper, lead and zinc concentrations were measured at different sites and habitats within the bay, although not all sites were tested for lead (Table 2.13). More sites were sampled in 2014 in addition to those from 2012-2013 and include samples taken from Rose Creek upstream of the mouth (Fig. 2.5), where Rose Creek empties into the channel (Fig. 2.5), at the Dana Landing Fuel Dock (Fig. 2.3), inside Quivira Basin (across from Mariner's Cove; Fig. 2.2), and out in the channel that leads out of Mission Bay (Fig. 2.2). Table 2.12 and figures 2.15-2.18 also highlights which samples were above the EPA effects range low (ERL) 
threshold for each metal. With one exception, no samples from the beaches exceeded the ERL benchmark for any of the three metals. However, the sample from Tecolote Creek in Spring 2014 had the highest concentrations compared to the other beach sites and exceeded the ERL for both copper and zinc (Table 2.12). This sample was collected closer to the creek mouth than those collected from the beach at Tecolote Creek in 2012 and 2013.

For samples taken from the channels, there were more that exceeded ERL thresholds for one or multiple metals compared to the beach samples (Fig. 2.16, Fig. 2.18). Near the creeks, Tecolote Creek basin and channel in 2013 both exceeded the ERL for all three metals, while Cudahy Creek channel in 2014 was close but did not exceed the threshold for any metal. Sediments collected in the channel near the mouth of Rose Creek in Spring 2014 exceeded the ERL for copper and was just below the threshold for zinc. The samples taken in Rose Creek in Spring 2014 showed almost the opposite pattern, with low copper detected at the creek beach and no copper in the creek bed, but the creek bed exceeded the ERL for zinc and was the highest value measured of any sample. The channel sample in Fiesta Bay was also found to exceed the ERL for all three metals. Inside the boat basins, copper was seen to be elevated at both sites and was above ERL, with Quivira Basin having the highest concentrations of any sample. Dana Landing also exceeded the ERL benchmark for zinc. The channel samples at Ventura Cove and Mariner's Cove were found to have very low concentrations of all metals, almost on par with those samples taken from the beach. The cleanest sample was collected in the channel leading out to the mouth of Mission Bay.

Multivariate analysis of $\mathrm{Cu}, \mathrm{Zn}$, and total PAHs was performed to determine if the combination of contaminants differed across sites. Principle components ordination (Fig. 2.19) represented a high percentage (97.1\%) of the total variation in the dataset. It showed distinct separation among sites, especially Tecolote Creek from Fiesta Bay and Ventura Cove. Mariner's Cove had moderate trends but grouped more closely to Ventura Cove, while Cudahy Creek was also moderate while grouping better with Tecolote Creek. Crown Point had 
weak trends and did not group well with any site. PERMANOVA analysis determined significant differences among sites, and pairwise comparison revealed that each site was statistically different from the other sites. CAP analysis determined that FB (100\%) and TC (87.5\%) were the two sites that were correctly identified the most by the model, while MC (43.5\%) and CP (50\%) were correctly identified the least, which is supported by the principle components ordination plot.

\subsection{2 - Temporal Variation}

For 2012-2013, rainfall was recorded at Sea World and compared to the past 15 years of rainfall data (Fig. 2.20). Overall, 2012-2013 was a relatively dry year with only $13.8 \mathrm{~cm}$ of rainfall compared to an annual average of $21.6 \mathrm{~cm}$. The first rainfall event of the year occurred early in October, and $0.3 \mathrm{~cm}$ of rain fell at Sea World marina. Total rainfall in each season was calculated by summing the rainfall from the start of each collection period until the end of that collection period.

Among the sediment parameters, median grain size and percent fine fraction differed significantly among seasons for beach samples. Median grain size was highest in the summer, while sediments were finest during spring and winter (Fig. 2.8). Perhaps due to a limited number of samples, there was no significant difference among seasons for channel samples, although the pattern does appear to be the same as the beach samples with grain size decreasing throughout the sampling period (Fig. 2.9). While some of the variation could be due to sediment heterogeneity, the trends from pre- and post-rainfall suggest that there are temporal patterns, especially in the back bay where creeks are able to deliver sediment and pollutants during seasonal rainfall events. The beach samples that were taken one and four days after the first rainfall event showed some general patterns when compared to those collected beforehand (Fig. 2.8). Compared to the samples before the rain event, the samples taken the day after show a slight decrease in grain size (except at Mariner's Cove), but overall the grain size does not change drastically. Samples collected four days post-rainfall 
showed a marked decrease in median grain size at all sites sampled (Fiesta Bay, Cudahy Creek and Tecolote Creek; Fig. 2.8).

Percent fine fraction showed a reciprocal pattern to median grain size, with winter having the highest percentage of fines followed by spring, and then summer and fall having the lowest percentage of fines (Fig. 2.10). There was no significant difference between seasons for the channel samples, and the temporal patterns are variable and site-specific (Fig. 2.11). Post-rainfall samples compared to pre-rainfall followed the sample pattern of change for percent fine fraction as median grain size (Fig. 2.10). All samples taken the day after the first rainfall show an increase in the percent fine fraction, except for Cudahy Creek. Four days after rainfall, all sites sampled showed a large increase in the percent fine fraction.

Core sediment samples were measured for 13 PAHs at each site over all seasons (Table 2.6). Beach samples collected from Mariners Cove, Ventura Cove and Fiesta Bay showed an increase in total PAHs from summer to fall, and then a decrease from winter to spring (Fig. 2.13). There was not a clear pattern for these sites with regard to the first rainfall event. Crown Point had an increase from summer to fall, with a marked increase the day after the first rainfall event, and maintained high concentrations in the winter until they decreased in the spring. Cudahy Creek had the highest overall concentrations of PAHs, but an increase from summer to fall with a big increase the day after the first rainfall event represents the biggest change out of any site. The concentrations stayed high in the winter before falling in the spring. Tecolote Creek had an interesting pattern of its PAH concentrations reducing from summer to the fall, and even reducing the first day after the first rainfall event before increasing four days after the rainfall event. Then the concentration of PAHs at Tecolote Creek increased for both winter and spring.

Core sediment samples from channel samples were measured for PAHs for only 3 seasons, and not all sites had coverage for all seasons (Fig. 2.14, Table 2.6). Mariners Cove channel decreased in concentration from fall to winter, but then the highest concentration was measured in the spring. Crown Point channel concentrations decreased each season from fall to spring. Cudahy Creek and 
Tecolote Creek channels both decreased in concentration from fall to winter, and then increased from winter to spring.

Metals were measured over various temporal scales, although the only samples from the same sites over all seasons are the beach samples from 20122013 (Table 2.13). For beach samples from Mariner's Cove, Ventura Cove and Fiesta Bay, there was little change between summer and fall (Fig. 2.15, Fig. 2.17). The day after the first rainfall of the season, concentrations of copper very slightly at each site (by $1.1 \mathrm{ppm}$ for Mariner's Cove, $0.1 \mathrm{ppm}$ for Ventura Cove and 1.9 ppm for Fiesta Bay). Concentrations of zinc also slightly increased after the first rainfall at Mariner's Cove, Ventura Cove and Fiesta Bay (by 5.3 ppm, 2.2 ppm and 5.4 ppm respectively). Fiesta Bay was also sampled four days post rain, and the concentrations of copper (11.9 ppm) and zinc (48.2 ppm) reached the highest levels recorded for that site at the beach. For these three sites in the winter and spring, the concentrations only slightly increased or stabilized. Beach sites and Crown Point, Cudahy Creek and Tecolote Creek had fluctuating patterns for summer into fall, but the largest increase from the first rainfall event was seen four days post rainfall. For Cudahy Creek, the concentration of copper increased from $14.3 \mathrm{ppm}$ to $19.4 \mathrm{ppm}$ four days post rainfall, while zinc increased from 56.7 ppm to $80.5 \mathrm{ppm}$. Tecolote Creek had an even larger increase going from 2.8 ppm copper to 14.7 ppm copper four days post rain, while zinc went from 22.4 ppm to $98.7 \mathrm{ppm}$. These three sites then reached their seasonal maximum when sampled in the winter, and slightly decreased again in the spring.

Channel samples were not regularly taken from each site at each season, although there was some replication for Mariners Cove, Crown Point, Cudahy Creek and Tecolote Creek (Fig. 2.16, Fig. 2.18). Mariners Cove channel was fairly consistent over the three seasons measured, as it slightly increased for both $\mathrm{Cu}$ and $\mathrm{Zn}$ during the winter, but returned to previous levels in the spring. For Crown Point, Cudahy Creek and Tecolote Creek however, there was a more defined seasonal pattern. Crown Point in the fall was above the ERL for both $\mathrm{Cu}$ and $\mathrm{Zn}$, but in the winter both concentrations were reduced with $\mathrm{Zn}$ falling just below the ERL threshold. In the spring, $\mathrm{Cu}$ had stabilized and was still above the 
ERL, but Zn continued to fall. Cudahy Creek had the most pronounced increase. During the fall, concentrations of $\mathrm{Cu}$ and $\mathrm{Zn}$ were both below ERL, but increased a little in the winter. In the spring however, both $\mathrm{Cu}$ and $\mathrm{Zn}$ were above the ERL. Tecolote Creek was the most consistent, but had a slight increase in $\mathrm{Cu}$ and $\mathrm{Zn}$ from the fall to the spring.

Multivariate analysis of $\mathrm{Cu}, \mathrm{Zn}$, and total PAHs was performed to determine if the combination of contaminants differed across seasons. Principle components ordination (Fig. 2.21) represented a high percentage (97.1\%) of the variation in the dataset. There were not distinct groupings that are apparent when looking at the PCO, many of the seasons were spread out on PCO axis 1. PERMANOVA analysis determined there was a significant difference between seasons. Pairwise comparison showed that each season was significantly different from each of the other seasons. CAP analysis determined that winter (78.7\%) and summer $(68 \%)$ were the seasons that were correctly identified the most. Fall $(52.9 \%)$ and spring (59.6\%) were correctly identified least, but still scored well within the model.

For all sites and seasons, Pearson product-moment correlation scores for sediment parameters, total rainfall in season and contaminant concentrations were calculated (Table 2.14). Rainfall significantly negatively correlated to temperature and salinity, as well as negatively correlating to median grain size. Both median grain size and percent fine fraction had significant correlations to the sediment contaminant concentrations, although median grain size had stronger correlations for all contaminants except PBDEs.

\section{4 - Discussion}

\subsection{1 - Effects of Rainfall}

Mission Bay shows a gradient of sediment properties and contaminant concentrations from the front to the back bay, and the sediments show seasonal variation. Near the creek mouths in the back of the bay there are finer-grained sediments that show more seasonal variation compared to the front bay (Fig. 2.8, Fig. 2.9), which can be expected as these are the most impacted by rainfall events 
and the drainage of nearby watersheds. Even during a relatively dry year, smaller rain events can mobilize fine-grained particles and dissolved pollutants into receiving waters (Brown et al. 2013). A study near the Ballona Creek and Malibu Creek outfalls in Los Angeles County found that storm water runoff increased concentrations of pesticides and PAHs and decreased grain sizes in marine sediments proportional to their proximity to the outfall (Bay et al. 1998). A study done on urban runoff from Ballona Creek watershed also showed that silt and clay were the predominant particles in the first 50-75\% of runoff volume, and that greater than $60 \%$ of the event mean concentration of $\mathrm{Cu}$ and $\mathrm{Zn}$ was associated with grain sizes less than $35 \mu \mathrm{m}$ (Brown et al. 2013). When looking at metals in highway runoff in Los Angeles, Kayhanian et al. (2008) found that toxicity associated with $\mathrm{Cu}$ and $\mathrm{Zn}$ varied with location and storm event, but that the most toxicity was associated with early storm duration periods. Compared to undeveloped watersheds in Southern California, developed watersheds had significantly higher concentrations of total and dissolved solids, nutrients, and metals while also displaying a first flush signal that was not seen in undeveloped watersheds (Yoon and Stein 2008). In this study, the day after the first rainfall event of the season in 2012 there was not a large change in median grain size or percent fine fraction, but an increase in metal concentrations was evident across all sites except Cudahy Creek which stayed about the same (Table 2.13). PAH concentrations did not have a uniform response the first day after the rainfall event, but Cudahy Creek beach showed the most dramatic increase (Table 2.6). This could be due to the nature of the watershed for Cudahy Creek, which drains a small residential watershed but also the large highway close by (Fig. 2.6), resulting in a stronger flushing signal for PAHs. This effect is seen in smaller watersheds in urban areas, while not observed in small, undeveloped watersheds (Yoon and Stein 2008). This delay versus the literature is most likely due to the samples from runoff in the literature coming from the impervious surfaces rather than in the sediment of the receiving water, so some delay in the effect can be expected. 
Four days after the rainfall event, the effects of sediment flushing through the watersheds surrounding Mission Bay was more evident, as there was a decrease in median grain size and increase in the percent fine fraction (Fig. 2.8, 2.9). Sediment contaminant concentrations showed the effect of extra time for the watersheds to flush, especially at Tecolote Creek which had large increases in $\mathrm{Cu}$, $\mathrm{Zn}$ and PAH concentrations. Tecolote Creek is a larger watershed that drains residential and commercial areas, therefore the metal and PAH concentrations changes may be reflective of the longer flushing time compared to Cudahy Creek (Yoon and Stein et al. 2008, Brown et al. 2013). This conclusion would be strengthened by future studies on runoff characteristics and discharge rates in these two watersheds. These results illustrates the importance of timing when considering sampling Mediterranean estuaries as there are inter-annual patterns to consider, but also short term variation over the time scale of a few days can be seen during pulse disturbances such as a large rainfall event.

\subsection{2 - Organics in Mission Bay}

The concentrations of PAHs, pyrethroids, fipronil and its degredates and PBDEs were significantly correlated to sediment characteristics like median grain size and percent fine fraction (Table. 2.14). The highest concentrations of organic contaminants were found in the back bay, specifically in the basin where Tecolote Creek empties into the bay. This area is the farthest from the mouth of the bay, and receives little tidal flushing (Largier et al. 1997), which means during dry periods it is a settling environment that allows contaminants to be adsorbed onto fine particles and retained in the surface sediments (Eggleton and Thomas 2004).

For fipronil and its degredates, the distribution is consistent with studies that show adsorption of these compounds in soils and aquatic sediments increases with total organic matter (Gunasekara and Troung 2007), which has previously been shown to be higher in the back regions of Mission Bay (Kaufmann et al. 2006). Lao et al. (2010) found that total fipronils in an urban watershed in southern California correlated with the percent fine fraction, which is consistent with the results from this study. The Ballona Creek study showed that the parent compound fipronil was found infrequently, and that fipronil sulfone made up over 
$50 \%$ of the total fipronils measured at each site. Fipronil was not detected above the detection limit $(0.123 \mathrm{ng} / \mathrm{g} \mathrm{dw})$ at any site in the Mission Bay study (Table 2.3). At Tecolote Creek channel and basin as well as Cudahy Creek channel in this study, fipronil sulfone also made up over $50 \%$ of the total fipronils. Fipronil desulfinyl was detected at Crown Point beach and channel while no other degradation products were found, but for sites where fipronil desulfinyl and fipronil sulfide were both detected, they were in roughly equal abundance. Mission Bay had lower values for total fipronils compared to the highest levels from Ballona Creek (1.94 $\mathrm{ng} \mathrm{gdw}^{-1}$ vs. $17 \mathrm{ng} \mathrm{gdw}^{-1}$ ), but still fell within the low end of the range of total fipronils measured in Ballona Creek (0.18-17 ng gdw $\left.{ }^{-1}\right)$. It should be noted that the samples from that study were taken during different seasons, with fall having higher values, versus the samples form Mission Bay coming only from the spring. The sediment concentrations are unique in that they are drastically different than those measured in surface waters from southern California. In urban areas with no commercial or agricultural inputs, Ensminger et al. (2013) found that Orange County surface waters had fipronil present in $71 \%$ of samples taken, and the maximum values for fipronil $\left(2.11 \mathrm{ug} \mathrm{L^{-1 }}\right)$ were much higher than the maximum values of fipronil sulfone $\left(0.55 \mathrm{ug} \mathrm{L^{-1 }}\right)$. As these compounds enter coastal habitats they are biotransformed in addition to being sequestered and transformed abiotically (Baird et al. 2013). This transformation is not of small consequence to the biota that comes in contact with the degradation products, as fipronil sulfone has been shown to be 6.3 times more toxic to rainbow trout and 3.3 times more toxic to bluegill compared to fipronil (Baird et al. 2013). This study is the first to characterize total fipronil concentrations in the marine sediments of Mission Bay, emphasizing the need to include these compounds in further coastal habitat monitoring and research into their impact on marine ecosystems.

Pyrethroids were detected at high levels never before measured in Mission Bay. The Bight '08 study found that pyrethroids were detected in $35 \%$ of the embayments within the SCB and at levels high enough to induce toxicity in the lab (total pyrethroids from 0.5-230 $\mu \mathrm{g} \mathrm{kg}^{-1}$; Schiff et al. 2011). Samples from 
Mission Bay had the highest concentrations in the back of the bay in the basin near Tecolote Creek and in the Cudahy Creek channel (124.59 $\mu \mathrm{g} \mathrm{kg}^{-1}$ and 32.82 $\mu \mathrm{gg}^{-1}$ respectively). The concentrations in the channels of Mission Bay are higher than the mean value found in the Bight '08 study for estuaries ( $\left.22 \mu \mathrm{g} \mathrm{kg}^{-1}\right)$, while the beach samples from the same sites had roughly half of the total pyrthroid concentrations of the Bight ' 08 mean value.

Permethrin was by far the compound found in the highest proportion in Mission Bay (58\% at Tecolote Creek basin), while the other two large contributors were bifenthrin (22\%) and cyfluthrin (11\%). Collectively the other four compounds detected made up only $9 \%$ of the total at Tecolote Creek basin. Tecolote Creek channel displayed a higher percentage of bifenthrin (50\%) compared to permethrin (35\%), showing that there is likely a high level of spatial variability even over short distances between sampling stations. Lao et al. (2012) found that in the Southern California Bight (SCB) bifenthrin and permethrin made up the highest percentage of the total pyrethroids measured in bays (46\% and 35\% respectively) and estuaries (45\% and $42 \%$ respectively). Cyfluthrin and cypermethrin were more abundant than the remaining four pyrethroids measured, but were more abundant in bays (9.7\% and $9 \%$ respectively) compared to estuaries (3.7\% and 5\% respectively). At Cudahy Creek beach and Crown Point beach and channel, bifenthrin was detected while no permethrin, cyfluthrin and cypermethrin was. This also agrees with Lao et al. (2012) as they found that at bay sites where pyrethroids were measured, bifenthrin was detected $100 \%$ of the time as opposed to $33 \%$ for cyfluthrin and $22 \%$ for cypermethrin (permethrin was excluded due to higher reporting limits). For estuary sites where pyrethroids were measured, bifenthrin was detected $100 \%$ of the time compared to $63 \%$ for cyfluthrin and $52 \%$ for cypermethrin. The rate of introduction to embayments (Schiff et al. 2011) and bioavailability of pyrethroids is still largely not understood, especially given the mixed contaminant profiles in the SCB (Lao et al. 2012, Schlenk et al. 2012). There is an increasing need to study these compounds when considering the ecological impacts of contaminated sediments. 
PBDEs were found to be prevalent in Mission Bay near the creek mouths, especially in the Tecolote Creek basin and Cudahy Creek channel (15.82 $\mathrm{ng} \mathrm{g}^{-1}$ and $6.14 \mathrm{ng} \mathrm{g}^{-1}$ respectively). PBDEs 99 and 47 made up the largest fraction of the totals (37\% and 20\% respectively at Tecolote Creek basin), with congeners 15, 153 and 100 combining to make up another 28\%. This is consistent with other work on PBDEs in the SCB by Dodder et al. (2012), who found that embayments near the Los Angeles and San Diego metropolitan areas had the highest PBDE concentrations, which decreased with increasing distance offshore. Their results indicated that PBDE 209 was present in the highest concentrations, which was not measured here, but the other two largest contributors were also PBDE 99 and 47, respectively. The highest concentrations of congeners 99 and 47 in Mission Bay were $5.92 \mathrm{ng} \mathrm{g}^{-1}$ and $3.13 \mathrm{ng} \mathrm{g}^{-1}$ respectively, which are both well above the $90^{\text {th }}$ percentile of values measured by Dodder et al. (2012) at 121 stations in the SCB (1.6 $\mathrm{ng} \mathrm{g}^{-1}$ and $1.4 \mathrm{ng} \mathrm{g}^{-1}$, respectively). Given the widespread distribution in the SCB and the propensity for these compounds to bioaccumulate, more attention should be put on these compounds in future monitoring (Schiff et al. 2011).

The highest concentrations of total PAHs were found in the back of the bay near the creek mouths for both the GC-MS and HPLC methods. For GC-MS, the highest concentration of the 26 PAHs was measured at Tecolote Creek basin $\left(1,066.7 \mu \mathrm{g} \mathrm{kg}^{-1}\right)$, while Cudahy Creek beach and Tecolote Creek channel also had very high concentrations (660.9 $\mu \mathrm{g} \mathrm{kg}^{-1}$ and $515.7 \mu \mathrm{g} \mathrm{kg}^{-1}$ respectively). For HPLC, the highest concentration of the 13 PAHs was also at Tecolote Creek basin $\left(1,111.89 \mu \mathrm{g} \mathrm{kg}^{-1}\right)$, with Cudahy Creek beach in the fall $\left(511.41 \mu \mathrm{g} \mathrm{kg}^{-1}\right)$ and Tecolote Creek channel in the fall $\left(588.48 \mu \mathrm{g} \mathrm{kg}^{-1}\right)$ and spring $\left(554.43 \mu \mathrm{g} \mathrm{kg}^{-1}\right)$ with high values. Previous work in Mission Bay by Kaufmann et al. (2006) measured 16 PAHs in channel habitats for four of the same sites over a two-year period. Their study found that the samples taken in August of their 2004-2005 sampling period were between 2-8 times higher than any other period sampled, with a maximum concentration at Tecolote Creek of $14,046 \mu \mathrm{g} \mathrm{kg}^{-1}$ vs. the mean value of $1,828 \mu \mathrm{g} \mathrm{kg}^{-1}$. In that season, the variability of sediment concentrations 
over short spatial scales $(<5 \mathrm{~m})$ was also demonstrated by the Tecolote Creek samples as one field replicate had $14,046 \mu \mathrm{g} \mathrm{kg}^{-1}$, while the other field replicate had $985 \mu \mathrm{g} \mathrm{kg}^{-1}$. The mean value Cudahy Creek $\left(1318 \mu \mathrm{g} \mathrm{kg}^{-1}\right)$ was also higher than the concentrations found in this study, but at both Tecolote Creek and Cudahy Creek the lowest concentrations from the 2004-2005 study were within the range of concentrations measured in this study. For Fiesta Bay and Ventura Cove, the values measured in this study were consistent with the mean values found by Kaufmann et al. (2006). The highest levels found in Mission Bay in this study do not exceed the highest total PAHs measured in other southern California embayments such as San Diego Bay $\left(6,740 \mu \mathrm{g} \mathrm{kg}^{-1}\right)$ or Los Angeles harbor $\left(11,000 \mu \mathrm{g} \mathrm{kg}^{-1}\right)$, but those areas also see a much higher level of commercial and military boat traffic (Sabin et al. 2010). However, the levels seen in the back of Mission Bay were comparable and in some cases higher than upper Newport Bay (657 $\mu \mathrm{g} \mathrm{kg}^{-1}$; Sabin et al. 2010). The Bight '08 study found that the habitat areaweighted means for bays $\left(503 \mu \mathrm{g} \mathrm{kg}^{-1}\right)$ and estuaries $\left(417 \mu \mathrm{g} \mathrm{kg}^{-1}\right)$ in the SCB were similar to values seen in Mission Bay (Schiff et al. 2011).

The two methods used in this study are not directly comparable due to the difference in preparation and total number of analytes, but the pattern of concentrations in the back bay is very similar. The HPLC method detected PAHs at all sites, whereas the GC-MS method did not detect any PAHs at Fiesta Bay, Ventura Cove or Mariner's Cove. It is not surprising to find PAHs spread across all sites in the bay due to the nature of Mission Bay being a large aquatic park that experiences high levels of recreational boat traffic both within the middle parts of the bay and coming and going from the mouth of the bay to the open ocean. Quivira Basin and Dana Landing are two boat basins that are close to the front of the bay and were sampled for PAHs. Quivira Basin is larger with more boats, and had higher PAH concentrations (484.44 $\mu \mathrm{g} \mathrm{kg}^{-1}$ ) compared to Dana Landing $\left(242.40 \mu \mathrm{g} \mathrm{kg}^{-1}\right)$. The sample from Quivira Basin was taken near the mouth of the marina, and further studies should investigate sediment quality away from the mouth of the basin near the boat moorings. The PAH profile from the GC-MS samples was dominated by high molecular weight, multi-ring compounds that are 
reflective of anthropogenic sources such as combustion engines that come from boats as well as urban runoff (Seruto et al. 2005, Sabin et al. 2010). This is notable because these multi-ring compounds have a more pronounced toxic effect on aquatic organisms, and in fish are more carcinogenic and major inducers of the CYP1A gene (Seruto et al. 2005, Fonseca et al. 2011a). In other embayments in southern California, this same pattern of predominately 4-6 ring PAHs in sediments has also been seen (Sabin et al. 2010). At Tecolote Creek basin, high molecular weight compounds made up $91 \%$ of total PAHs, and 4- and 5-ring compounds made up $43 \%$ and $37 \%$ of the total, respectively.

\subsection{3 - Metals in Mission Bay}

Metal concentrations had variable distribution in the bay, with the clearest patterns seen in the beach versus the channel/basin samples. The beach samples showed a pattern of progressively lower concentrations from the back to the front bay, with Tecolote Creek and Crown Point having higher concentrations than Ventura Cove and Mariner's Cove. This could be due to the influence of the creeks in the back of the bay, as it has been shown that metals in urban runoff are added from rainfall leaching metals from roofing, siding, and highways (Davis et al. 2001). Wear from brake pads are a significant source of $\mathrm{Cu}$ to the environment, tire wear is a large source of zinc, and housing materials is a source of both metals. However, only Tecolote Creek beach from 2014 exceeded the EPA ERL threshold for copper and zinc. This sample was different from those collected in 2012-13 because it was located next to the creek mouth, whereas the 2012-2013 samples were collected across the basin on the Fiesta Bay side (Fig. 2.6). This difference in sampling location may help to explain the elevated metals concentration since the 2014 samples were collected closer to the source of the metals coming out of the watershed. The channel and basin samples from many sites exhibited metal concentrations above the ERL thresholds, and this could be due to the finer-grained sediments found in these areas. Near the front bay, Ventura Cove and Mariner's Cove were well below the ERL thresholds for all three metals. Samples taken in the boat basins showed that there are areas with high metal concentrations near the front of the bay that are likely not due to urban 
runoff. These areas had the highest concentrations of copper measured at any sites in the bay, which could be attributed to the presence of boats (Schiff et al. 2004) and the anti-fouling paints they use which commonly use copper and zinc in their formulations (Turner et al. 2010). Passive leaching of metals from these paints as well as paint chips that are scraped off during cleaning are direct sources of copper and zinc to sediments below boats (Schiff et al. 2004, Turner et al. 2010). Copper was elevated above the ERL at both the Dana Landing fuel dock and at the Quivira Basin lifeguard dock.

Kaufmann et al. (2006) measured metal concentrations in Mission Bay at several channel sites that were the same as those sampled this study (Tecolote Creek, Cudahy Creek, Fiesta Bay, Ventura Cove). Their samples spanned two full years, and found that concentrations were variable over seasons. For Tecolote Creek and Cudahy Creek, the concentrations of copper and zinc measured in this study were higher than the mean values and the maximum values reported previously, which could reflect sediment loading in the time between sampling. Fiesta Bay and Ventura Cove did not have values that were different from those previously reported.

\subsection{4 - Conclusions}

Contaminant concentrations in Mission Bay have garnered less attention compared to other embayments in the regional monitoring programs such as the SCB studies, but this work highlights the need to include more extensive coverage of Mission Bay within the regional framework. In general, beach habitats had lower contaminant concentrations compared to channel habitats, which should be considered in future designs of monitoring within Mission Bay. In addition to further efforts to quantify these contaminants, additional work to relate their concentrations to biological effects will enhance our understanding of how these natural gradients affect biological communities and fisheries for species that rely on embayments as nursery areas. 


\section{5 - Figures and Tables}



Figure 2.1 Map of Mission Bay, San Diego, CA. Sampling sites are indicated by light diamonds. 


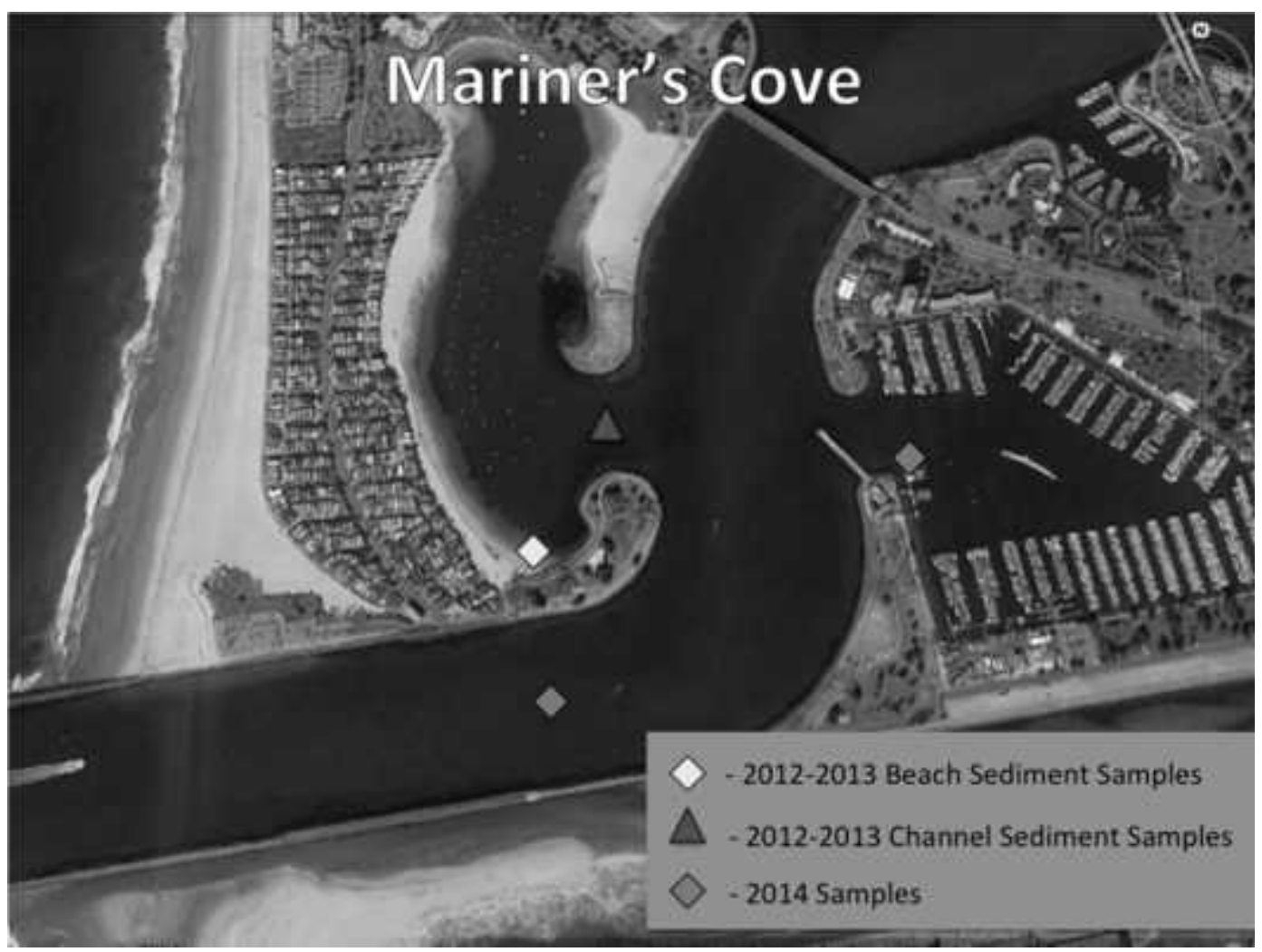

Figure 2.2 Map of Mariner's Cove showing sediment collection sites. The light diamond marks site where beach samples were taken in 2012-2013. The triangle marks where channel samples were taken in 2012-2013. The dark diamonds mark sites where samples were taken in Quivira Basin (right) and Mission Bay channel (center) in 2014. 


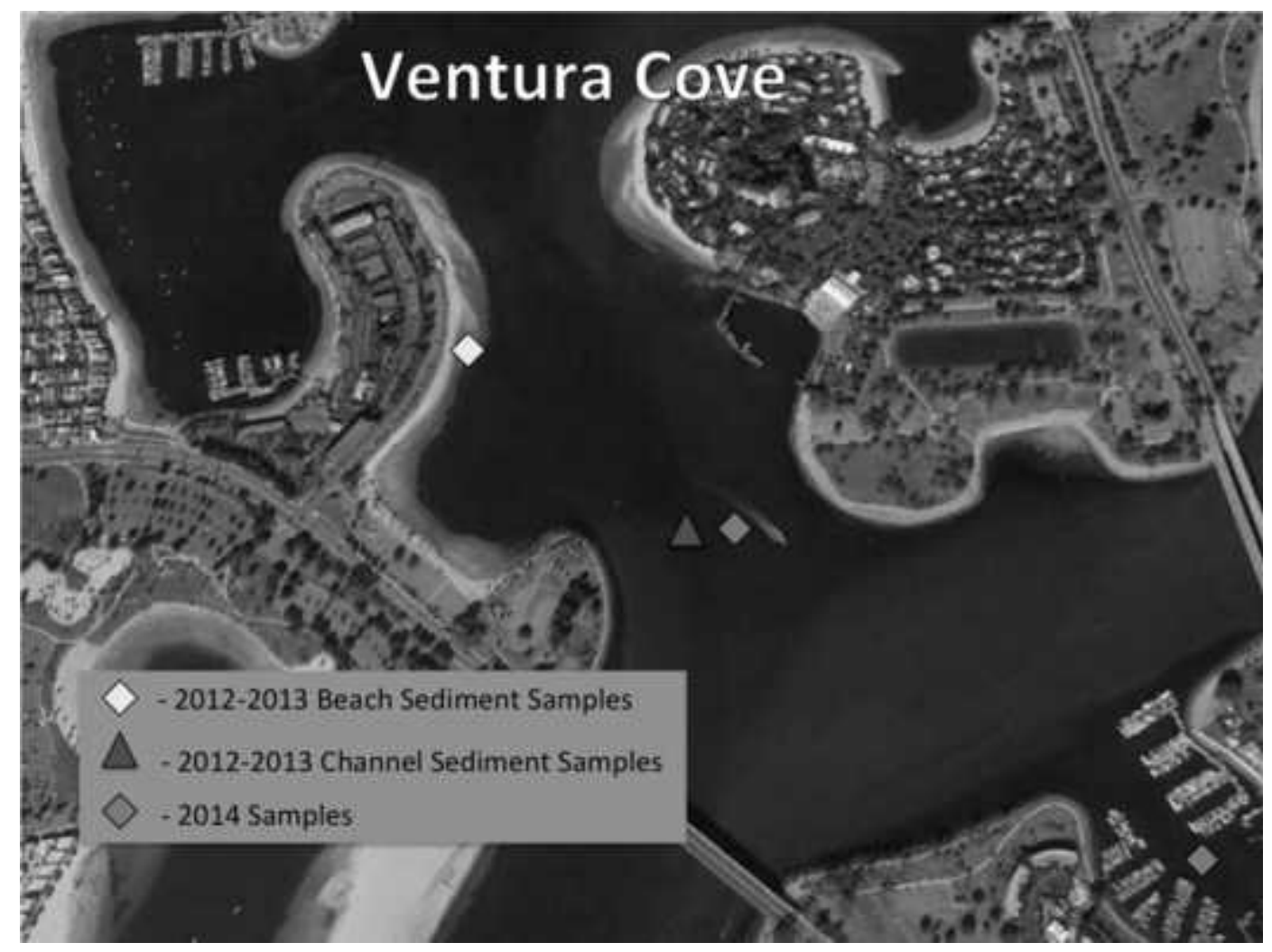

Figure 2.3 Map of Ventura Cove showing sediment collection sites. The light diamond marks site where beach samples were taken in 2012-2013. The triangle marks where channel samples were taken in 2012-2013. The dark diamonds mark sites where samples were taken at Ventura Cove channel (center) and Dana Landing (right) in 2014. 


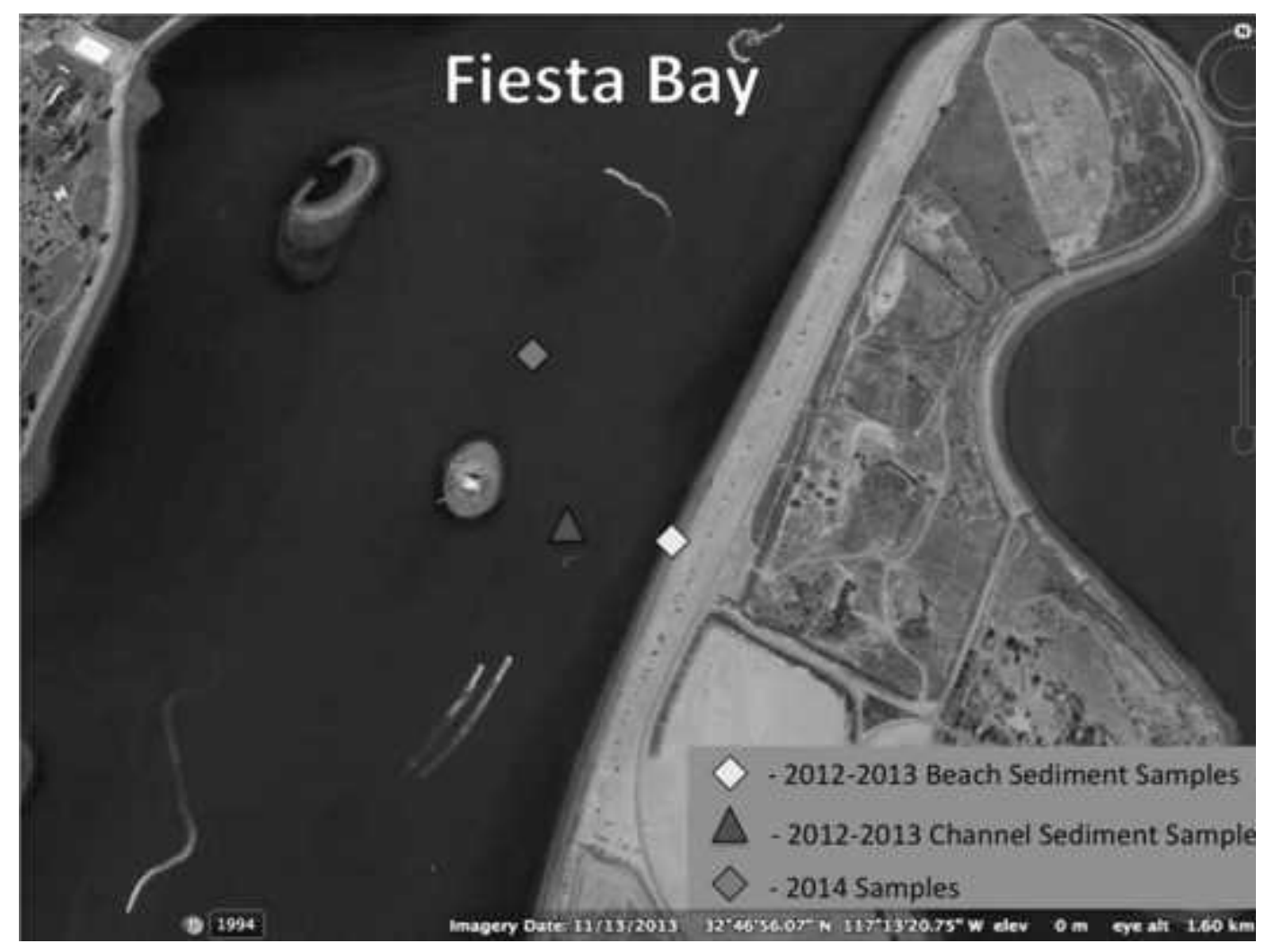

Figure 2.4 Map of Fiesta Bay showing sediment collection sites. The light diamond marks site where beach samples were taken in 2012-2013. The triangle marks where channel samples were taken in 2012-2013. The dark diamond marks site where samples were taken in 2014. 




Figure 2.5 Map of Crown Point and Rose Creek showing sediment collection sites. The light diamond marks site where beach samples were taken in 20122013. The triangle marks where channel samples were taken in 2012-2013. The dark diamonds mark sites where samples were taken in Rose Creek bed and creek bank (top) and the Rose Creek channel (center) in 2014. 


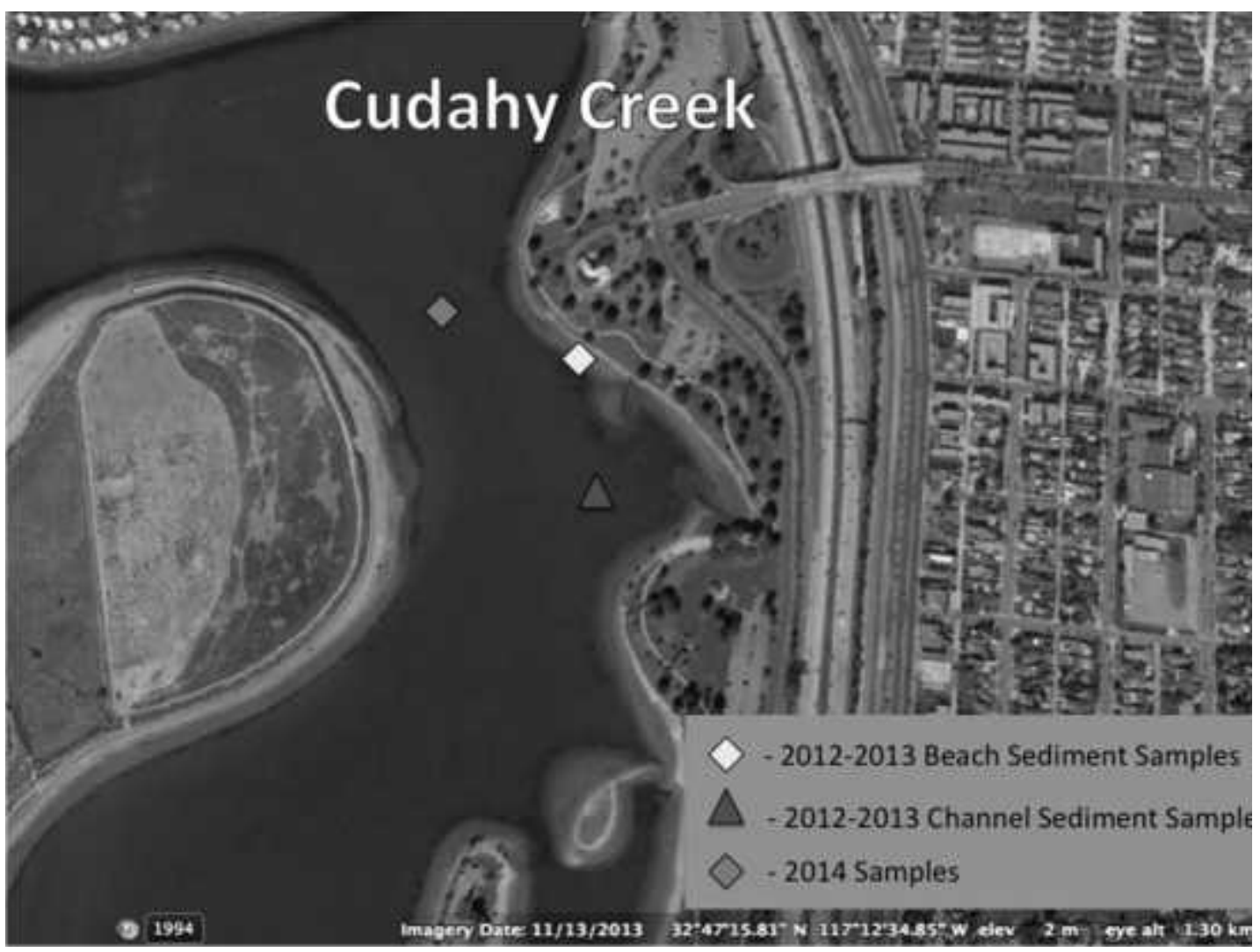

Figure 2.6 Map of Cudahy Creek showing sediment collection sites. The light diamond marks site where beach samples were taken in 2012-2013. The triangle marks where channel samples were taken in 2012-2013. The dark diamond marks site where samples were taken in 2014. 


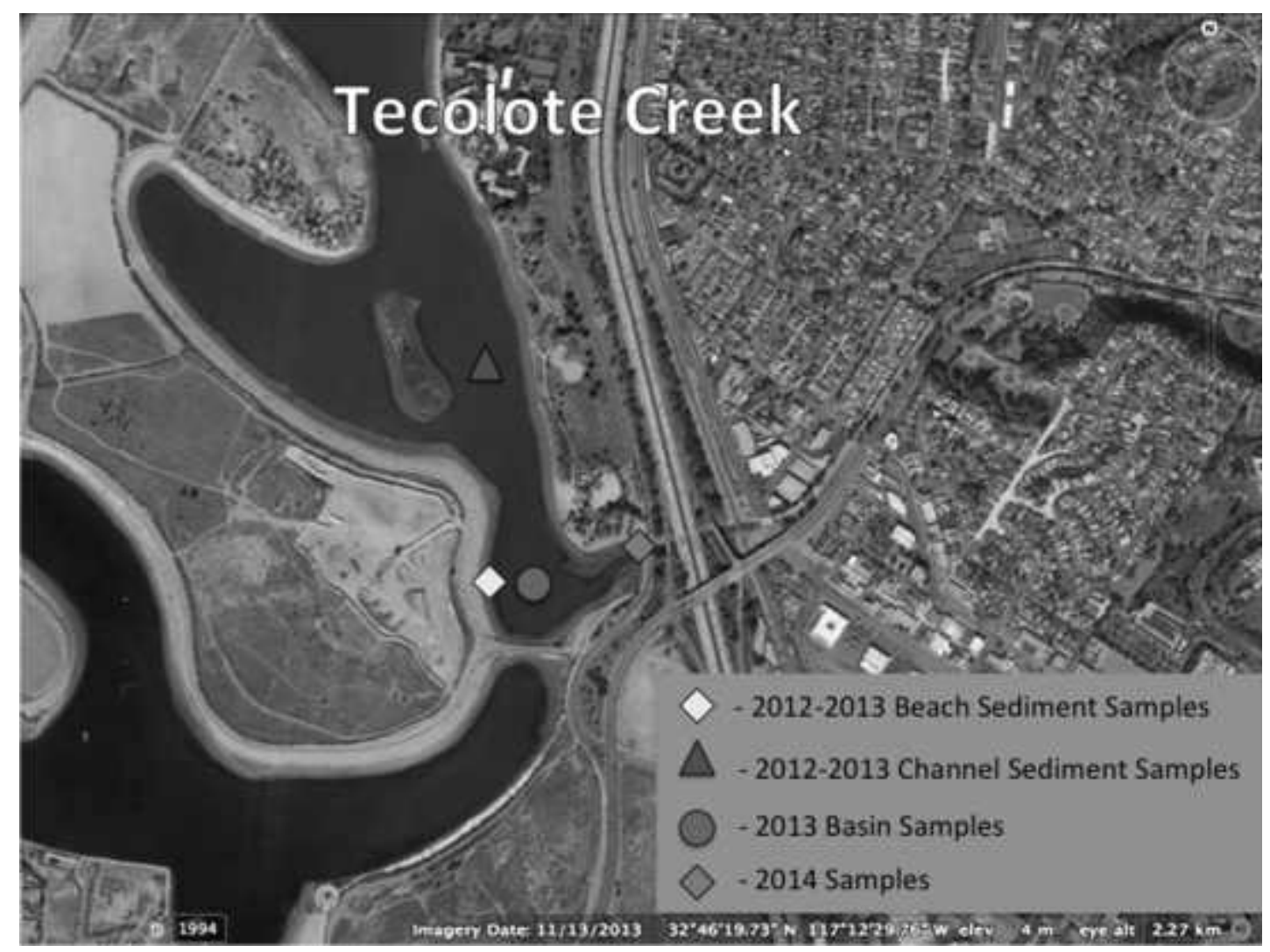

Figure 2.7 Map of Tecolote Creek showing sediment collection sites. The light diamond marks the site where beach samples were taken in 2012-2013. The triangle marks where channel samples were taken in 2012-2013. The dark diamond marks the site where samples were taken in 2014. 


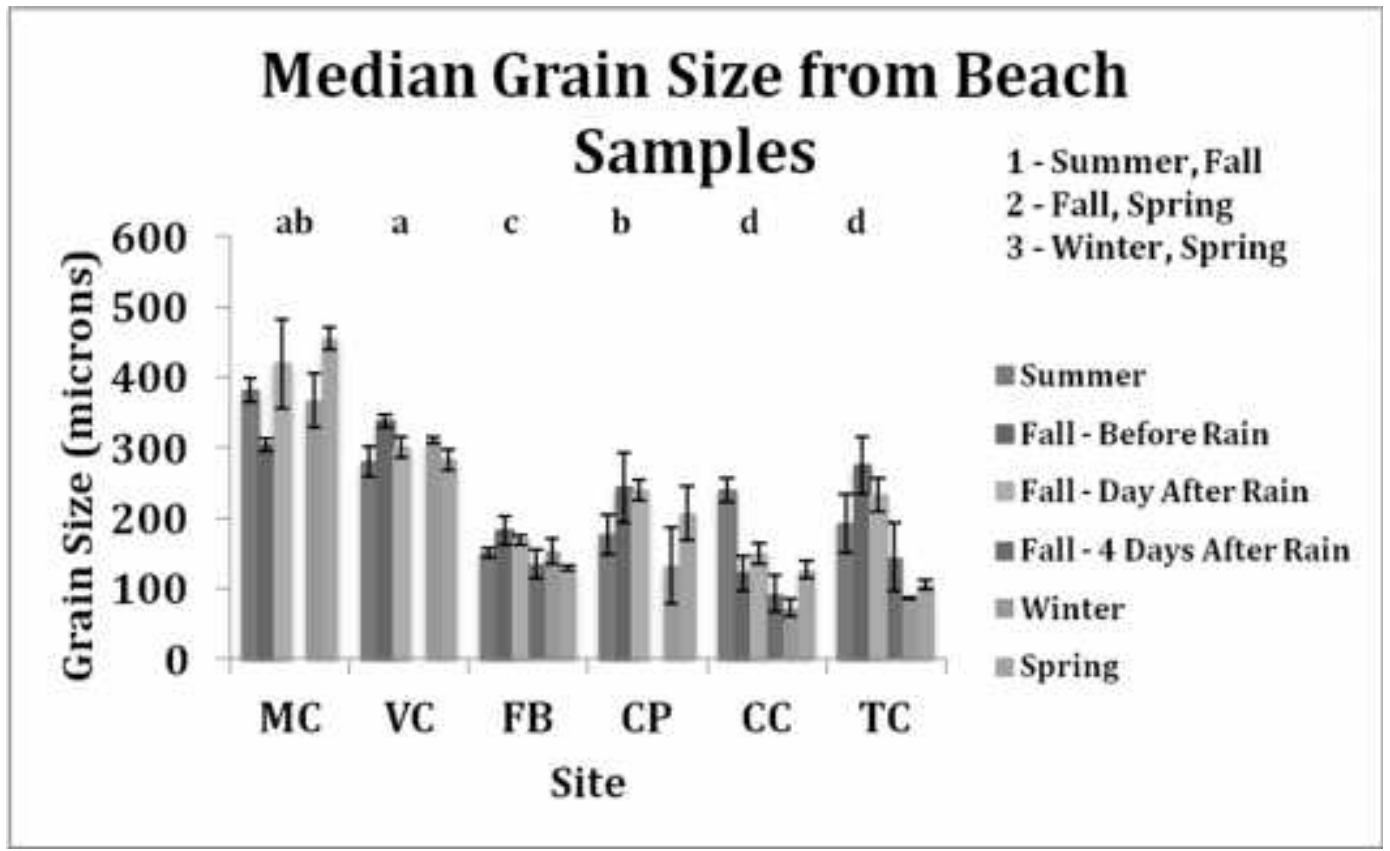

Figure 2.8 Median grain size for sediments collected at beach sites during each sampling event. Whiskers show one standard deviation. Numbers indicate significant groupings for seasonal differences based on Kruskal-Wallis and post hoc Mann-Whitney $\mathrm{U}$ tests. Letters above bars represent significant groupings for site differences based on Kruskal-Wallis and post hoc MannWhitney U tests. Fall samples were collected on three dates: before the first rainfall of the year, one day after and four days after the first rainfall event. 


\section{Median Grain Size from Channel Samples}



Figure 2.9 Median grain size for channel samples during each sampling event. Whiskers show one standard deviation. A sample from the basin at the mouth of Tecolote Creek was collected during Spring 2013. 


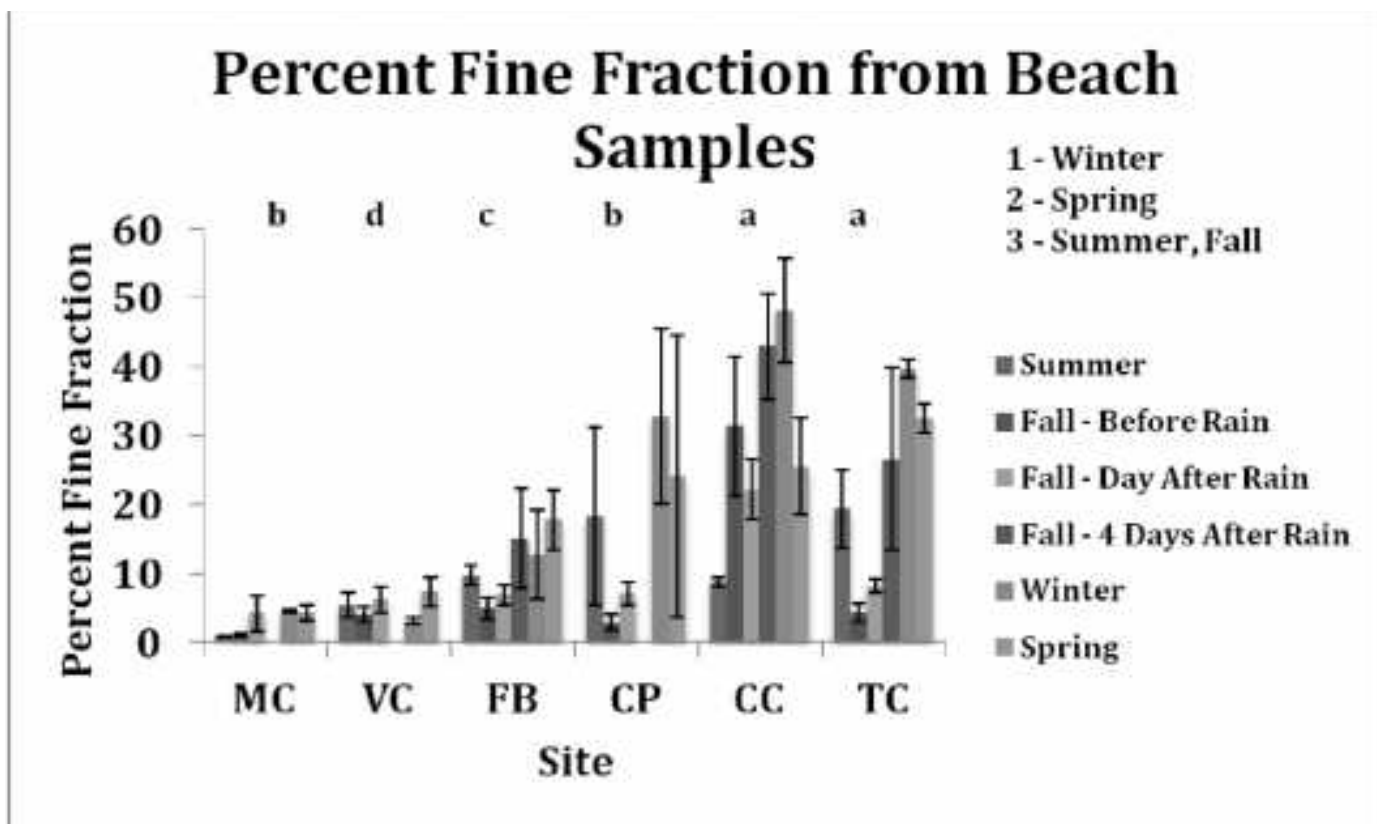

Figure 2.10 Percent fine fraction $(<63 \mathrm{~m})$ from each beach site during each sampling event. Whiskers represent one standard deviation. Number represent significant groupings for seasonal differences based on Kruskal-Wallis and post hoc Mann-Whitney U tests. Letters above bars represent significant groupings for site differences based on Kruskal-Wallis and post hoc MannWhitney U tests. Fall samples were collected on three dates: before the first rainfall of the year, one day after and four days after the first rainfall event. 


\section{Percent Fine Fraction from Channel Samples}

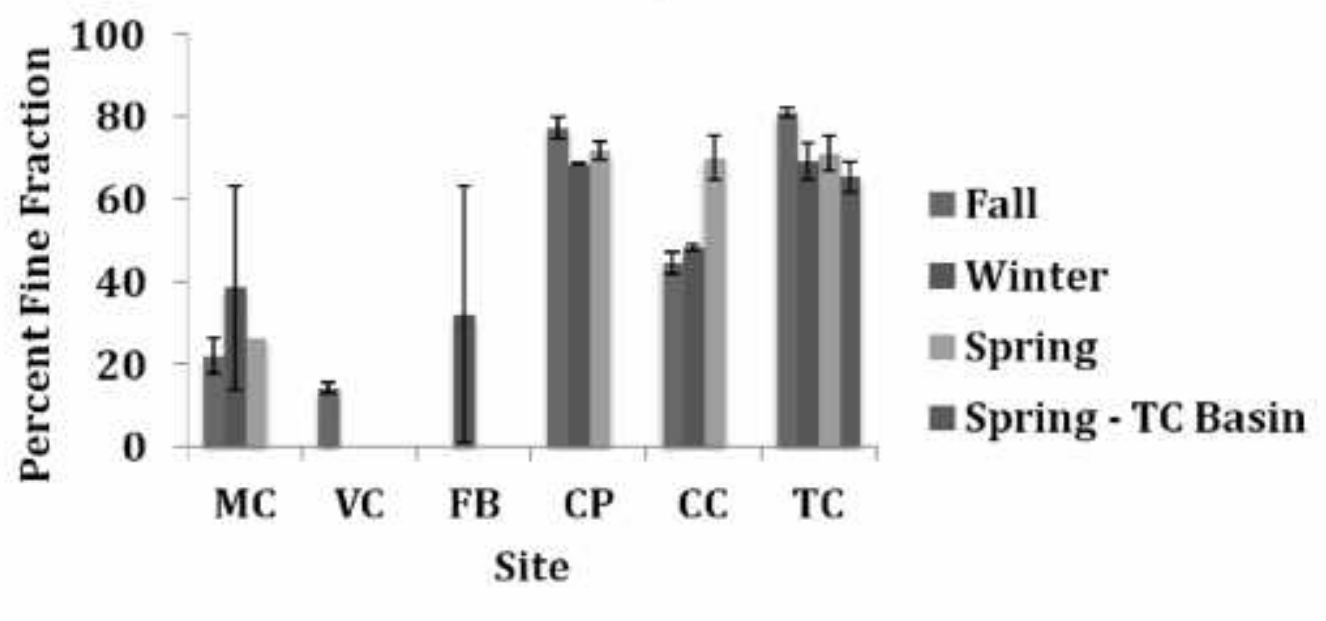

Figure 2.11 Percent fine fraction $(<63 \mathrm{~m})$ from each channel site during each sampling event. Whiskers show one standard deviation. A sample from the basin at the mouth of Tecolote Creek was also collected during Spring 2013. 


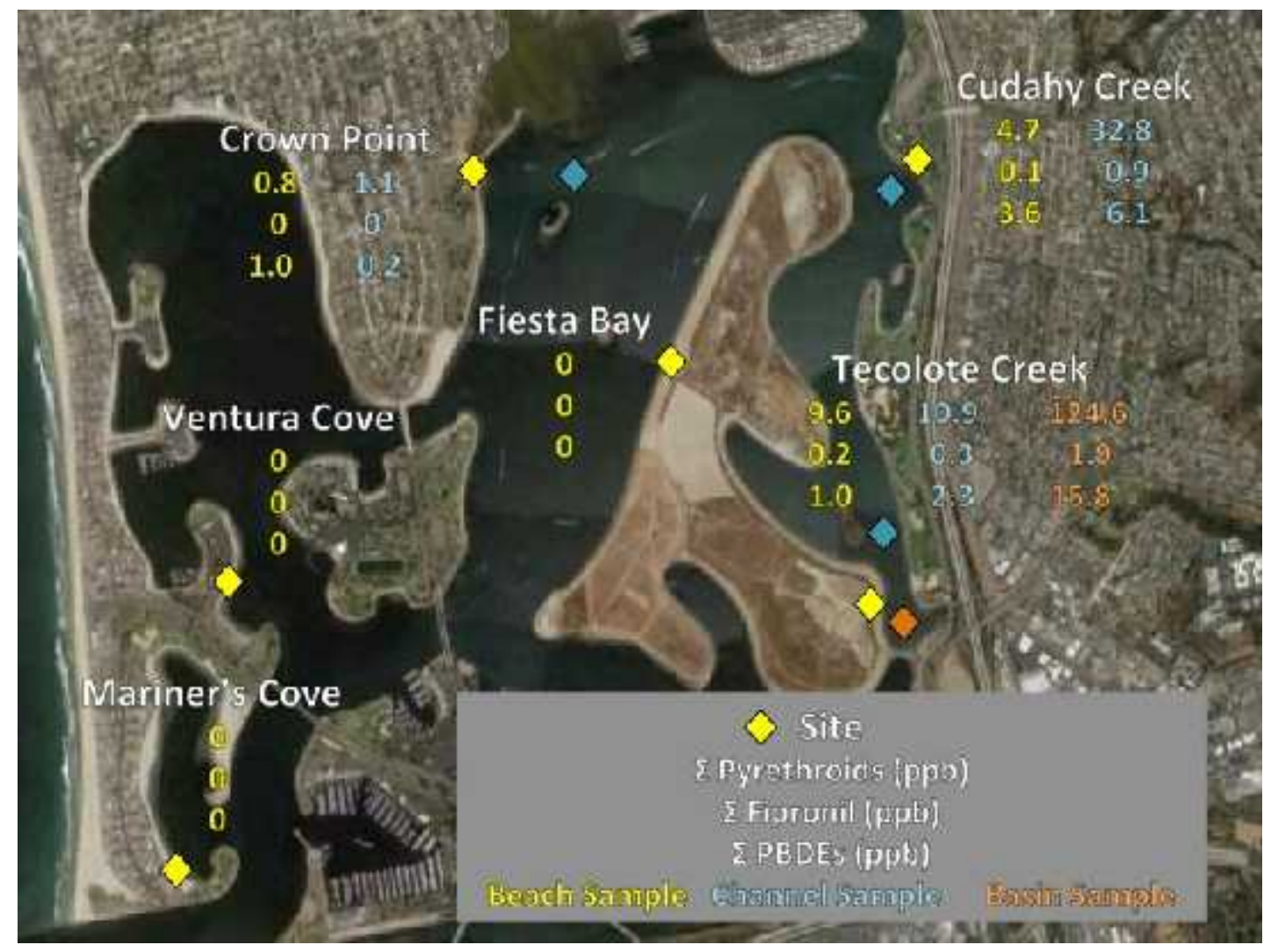

Figure 2.12 Map showing locations of sediment samples from 2013 analyzed for pyrethroids, fipronil and PBDEs. Yellow diamonds and numbers represent beach samples, blue diamonds and numbers represent channel samples, and orange diamonds and numbers represent basin samples. All numbers are concentrations in $\mathrm{ppb}$. 


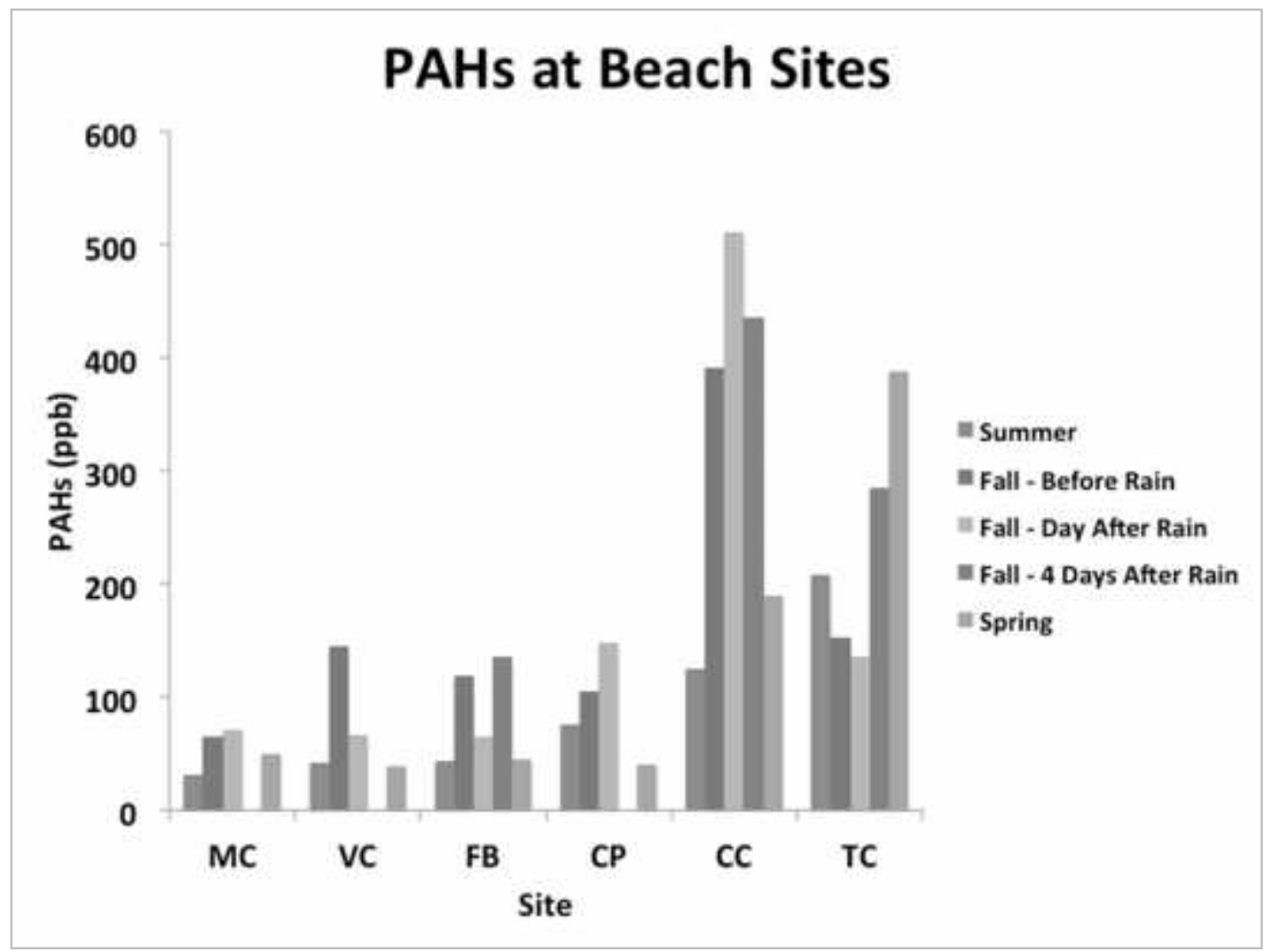

Figure 2.13 PAH concentrations ( $\mathrm{ppb}$ ) measured at beach sites in Mission Bay during each season. 




Figure 2.14 PAH concentrations (ppb) measured at channel and basin sites during each season. 


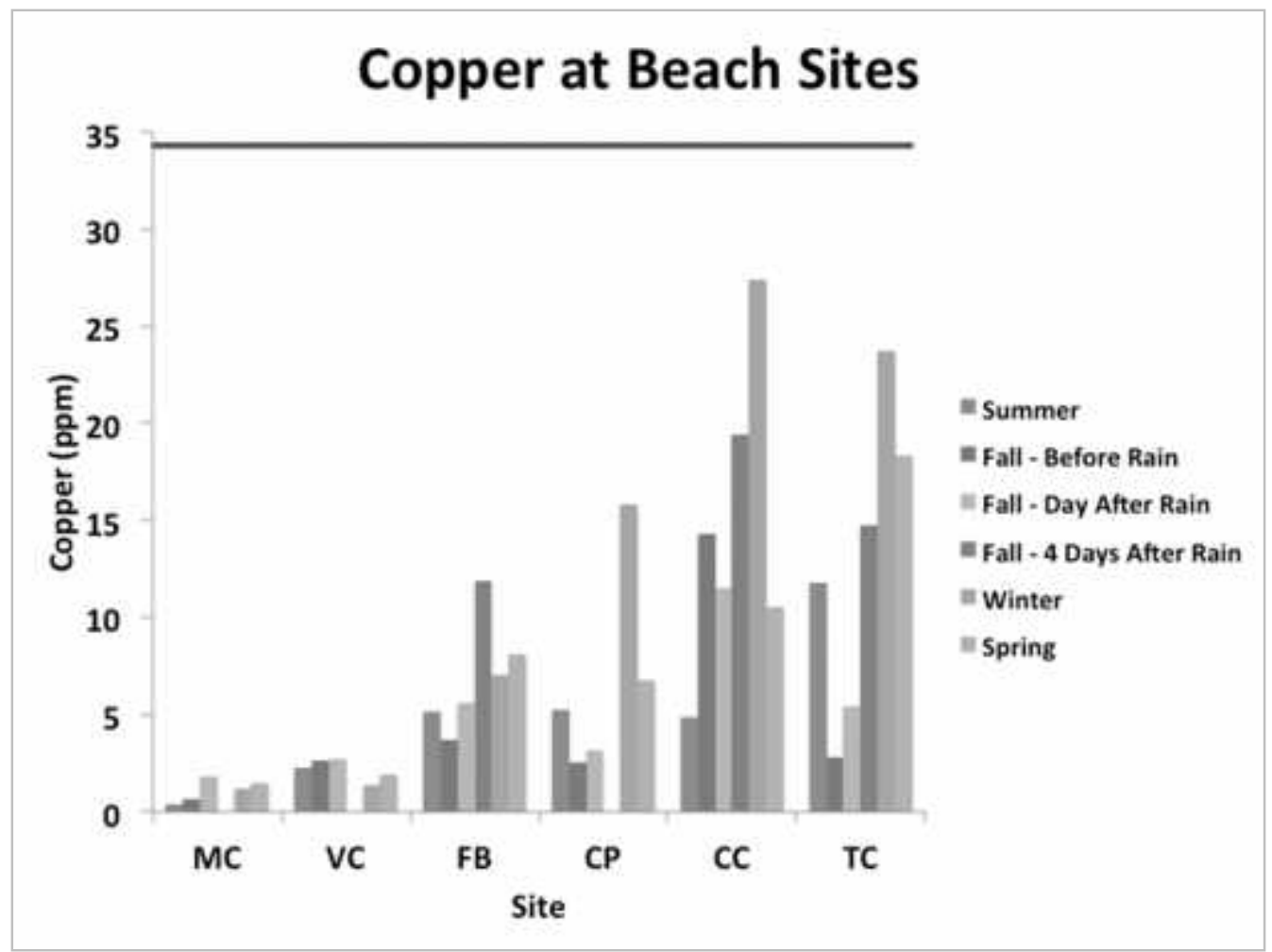

Figure 2.15 Copper concentrations (ppm) measured at beach sites during each season. The line indicates the EPA effects range low (ERL) concentration of $34 \mathrm{ppm}$. 


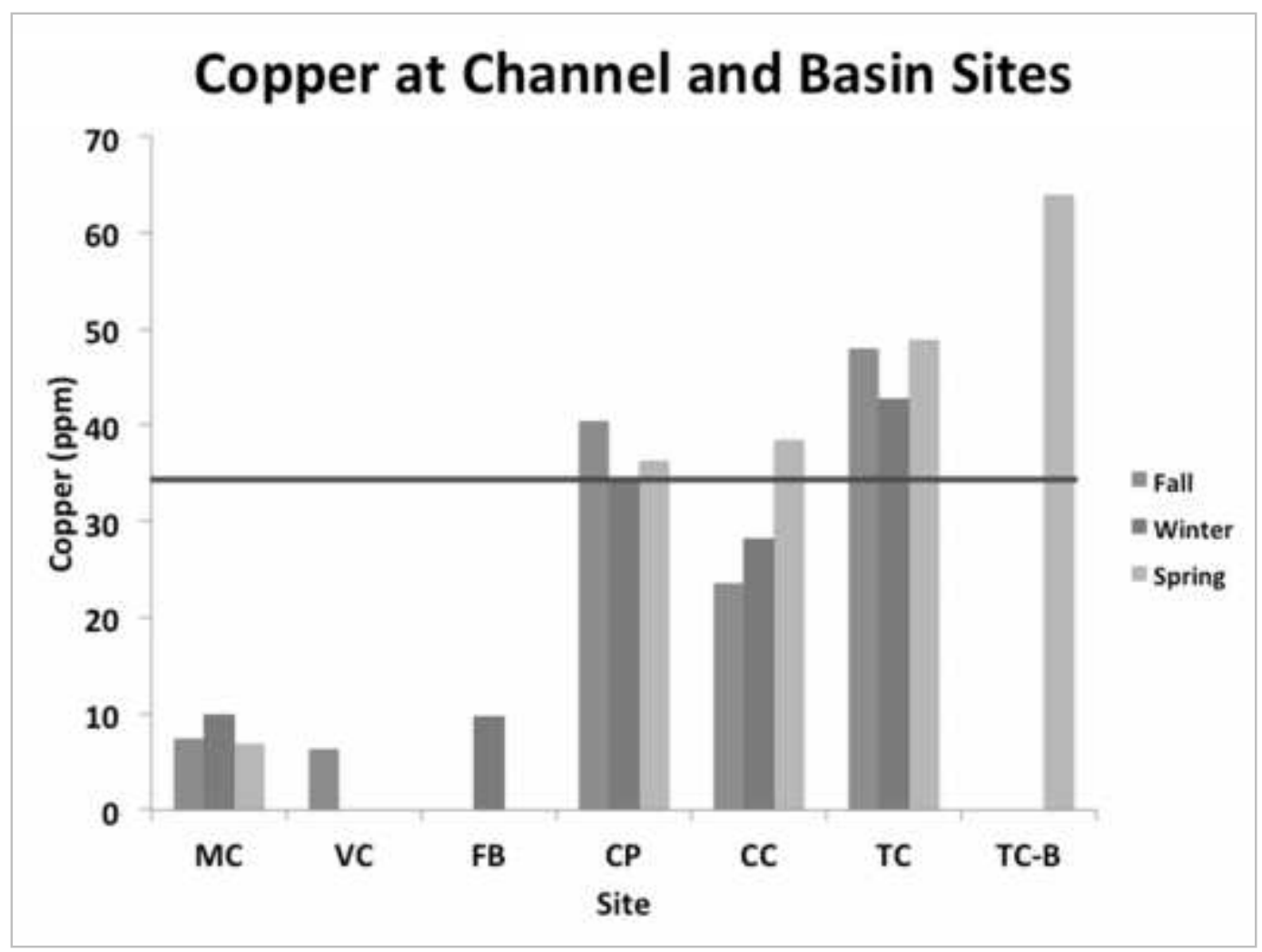

Figure 2.16 Copper concentrations (ppm) measured at channel and basin sites during fall, winter and spring. The line indicates the EPA effects range low (ERL) concentration of $34 \mathrm{ppm}$. 




Figure 2.17 Zinc concentrations (ppm) measured at beach sites during each season. The line indicates the EPA effects range low (ERL) concentration of $150 \mathrm{ppm}$. 


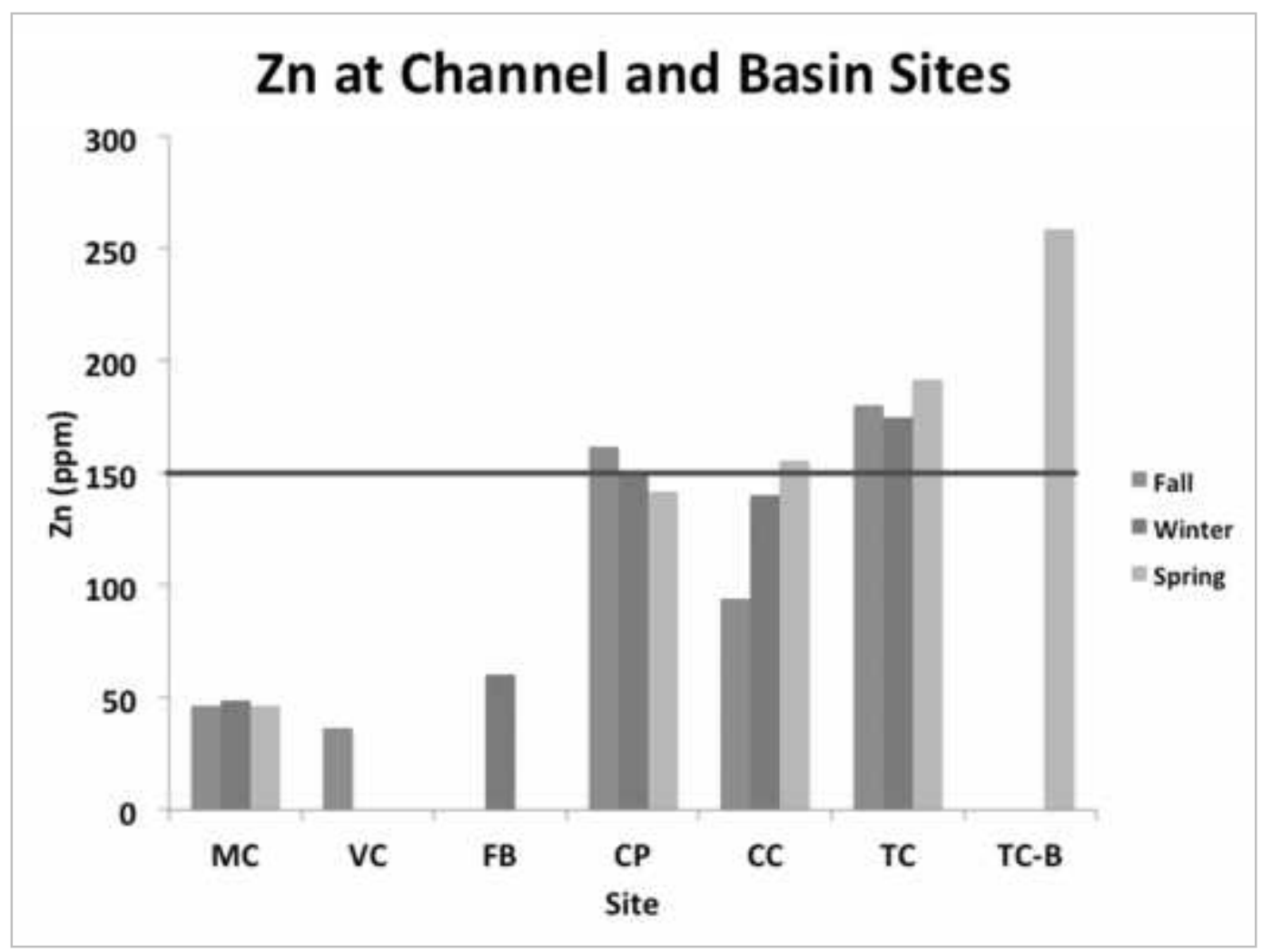

Figure 2.18 Zinc concentrations (ppm) measured at channel and basin sites during fall, winter and spring. The line indicates the EPA effects range low (ERL) concentration of $150 \mathrm{ppm}$. 


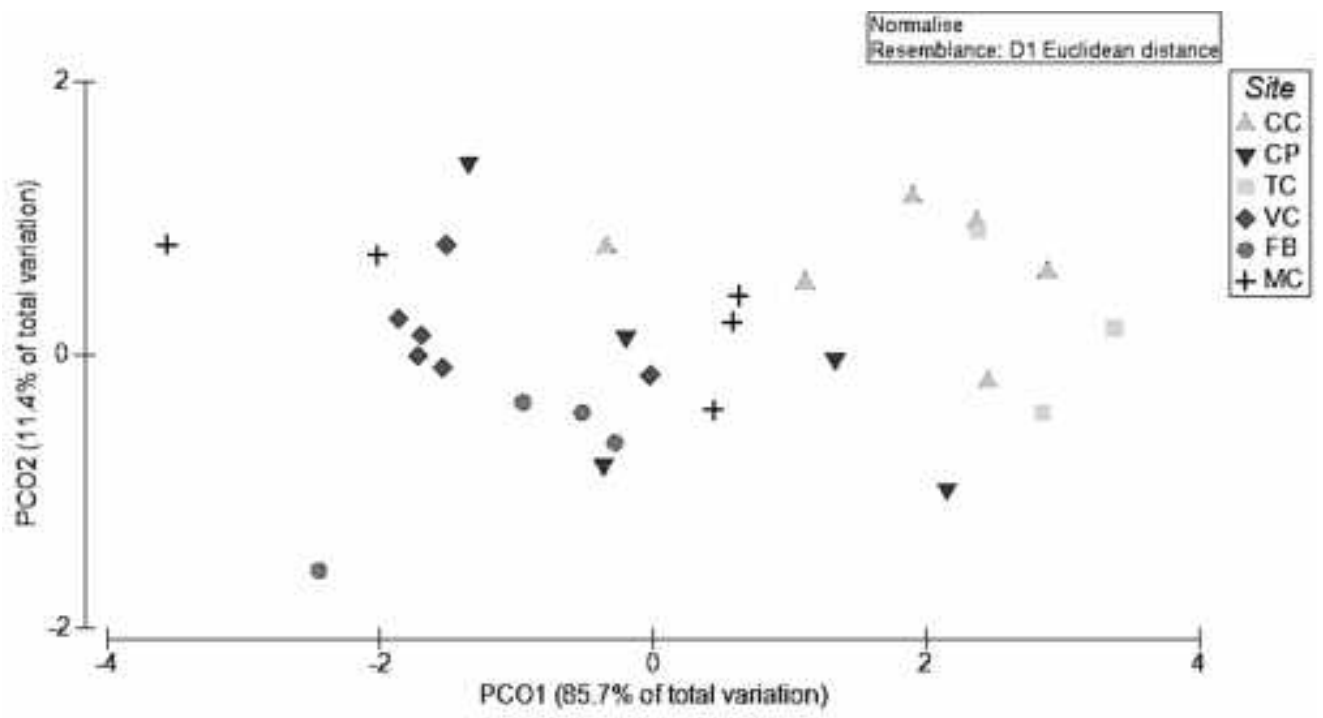

Table 2.19 Principle components ordination (PCO) of sediment concentrations of $\mathrm{Cu}, \mathrm{Zn}$ and total PAHs by site. Light triangles are Cudahy Creek, dark triangles are Crown Point, light squares are Tecolote Creek, dark diamonds are Ventura Cove, dark circles are Fiesta Bay and crosses are Mariner's Cove. 


\section{Sea World Rainfall 2012-13 and Mean Rainfall from 1999-2013}

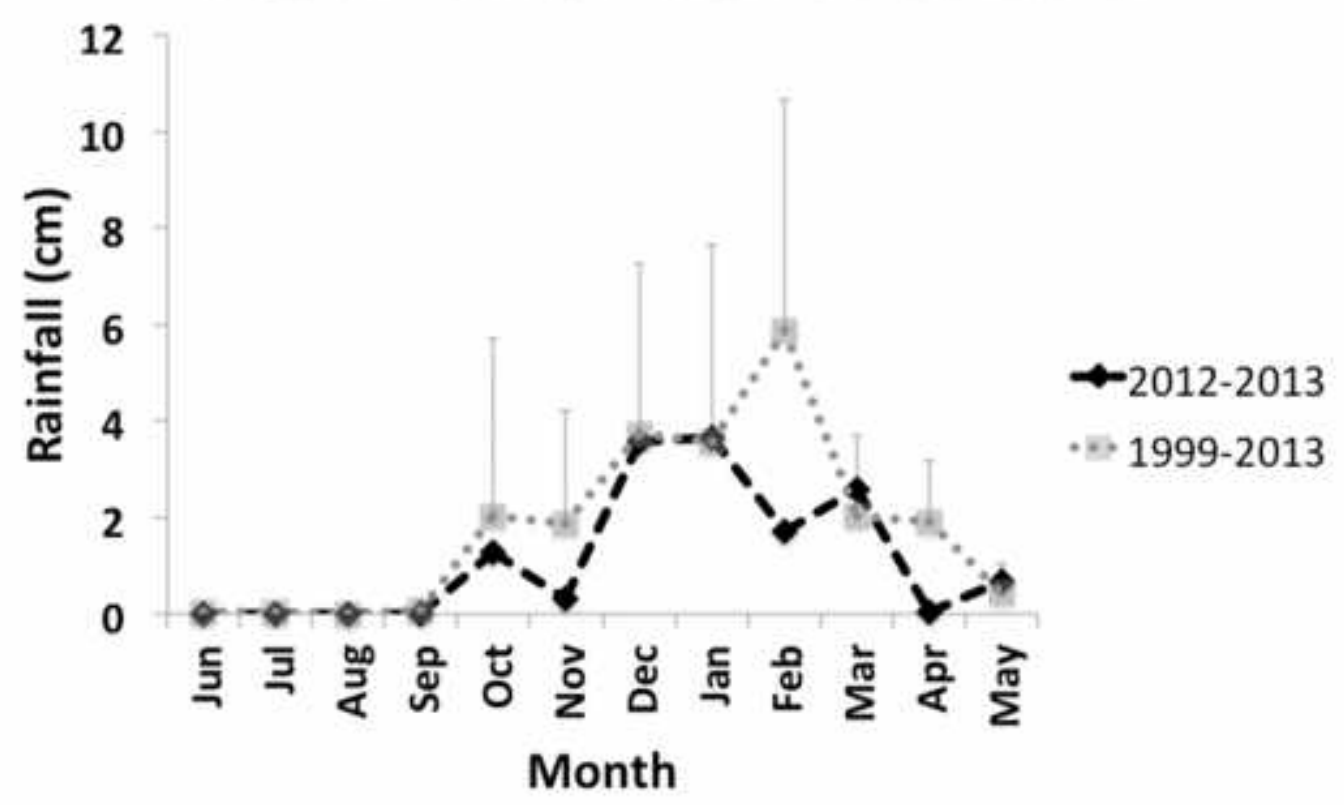

Figure 2.20 Mean monthly rainfall at Sea World, adjacent to Mission Bay. Monthly means for 1999-2013 are indicated by squares, connected by a dashed line; whiskers show one standard deviation from the mean. Monthly total rainfall for 2012-2013 shown in diamonds connected by a dashed line. Compared to the 14 year mean, 2012-2013 was relatively dry (total July-June rainfall was $13.8 \mathrm{~cm}$ vs. $21.8 \mathrm{~cm}$ from 1999-2013), with just over half of the rainfall in December and January. The first rainfall of 2012-2013 was during the second week of October. 


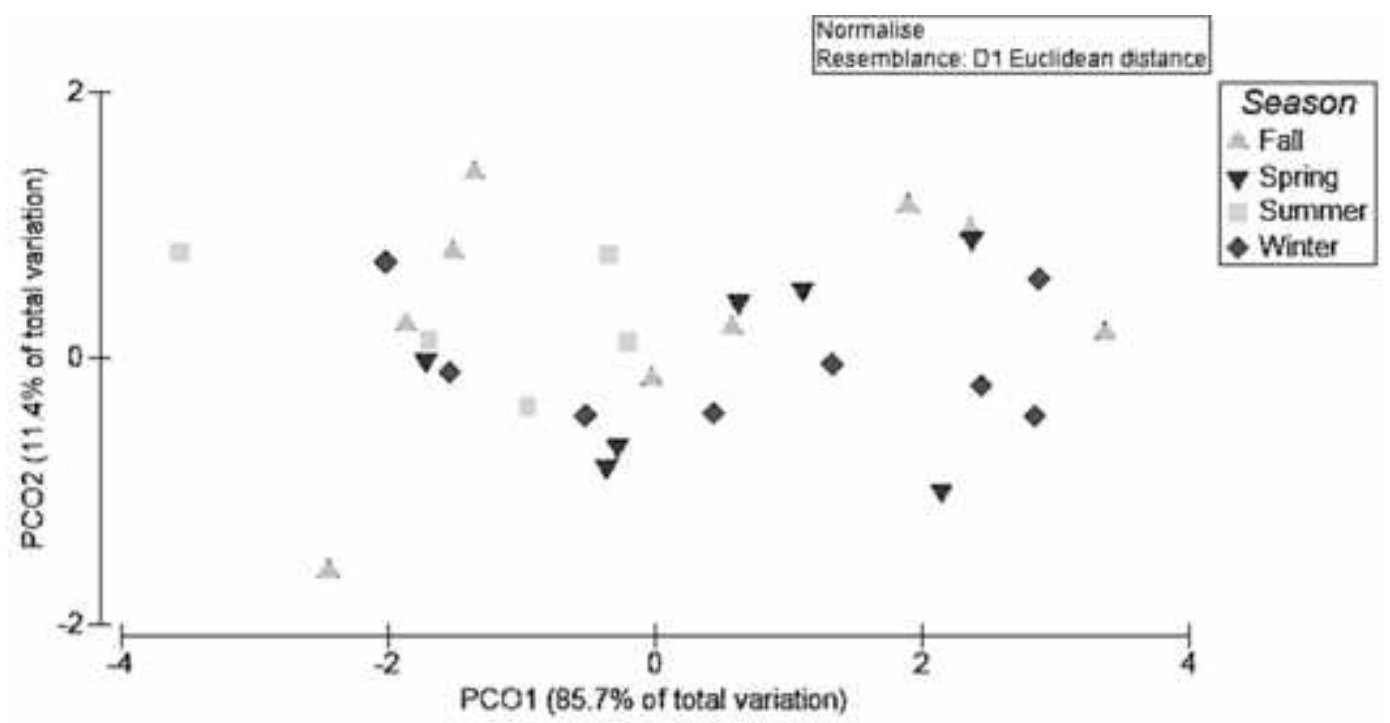

Figure 2.21 Principle components ordination (PCO) of sediment concentrations of $\mathrm{Cu}, \mathrm{Zn}$ and total PAHs by season. Light triangles are fall, dark triangles are spring, light squares are summer and dark diamonds are winter. 


\begin{tabular}{|c|c|c|c|}
\hline Compound & Limit of Quantification & Compound & Limit of Quantification \\
\hline \multicolumn{2}{|c|}{ ng gdw ${ }^{-1}$} & \multicolumn{2}{|r|}{ ng gdw ${ }^{-1}$} \\
\hline Fipronil desulfinyl & 0.014 & BDE 15 & 0.667 \\
\hline Fipronil sulfide & 0.013 & BDE 33 & 0.122 \\
\hline Fipronil & 0.123 & BDE 28 & 0.14 \\
\hline Fipronil sulfone & 0.084 & BDE 75 & 0.055 \\
\hline Bifenthrin & 0.098 & BDE 49 & 0.097 \\
\hline Fenpropathrin & 0.091 & BDE 47 & 0.107 \\
\hline Lambda-Cyhalothrin & 0.047 & BDE 66 & 0.121 \\
\hline Permethrin & 1.00 & BDE 100 & 0.052 \\
\hline Cyfluthrin & 0.089 & BDE 119 & 0.071 \\
\hline Cypermethrin & 0.069 & BDE 99 & 0.097 \\
\hline Esfenvalerate & 0.038 & BDE 155 & 0.031 \\
\hline Deltamethrin & 0.455 & BDE 154 & 0.027 \\
\hline Compound & & BDE 153 & 0.041 \\
\hline All 26 PAHs & 1.00 & BDE 183 & 0.122 \\
\hline
\end{tabular}

Table 2.1 Limit of quantification (LOQ) for PAHs, fipronil and its degradates, pyrethroids, and PBDEs in ng gdw ${ }^{-1}$ measured in bulk sediments by SCCWRP. 


\begin{tabular}{|c|c|c|c|c|c|c|c|c|c|c|}
\hline & $\begin{array}{l}\text { MC } \\
\text { Beach }\end{array}$ & $\begin{array}{l}\text { VC } \\
\text { Beach }\end{array}$ & $\begin{array}{l}\text { FB } \\
\text { Beach }\end{array}$ & $\begin{array}{l}\text { CP } \\
\text { Beach }\end{array}$ & $\begin{array}{l}\text { CP } \\
\text { Channel }\end{array}$ & $\begin{array}{l}\text { CC } \\
\text { Beach }\end{array}$ & $\begin{array}{l}\text { CC } \\
\text { Channel }\end{array}$ & $\begin{array}{l}\text { TC } \\
\text { Beach }\end{array}$ & $\begin{array}{l}\text { TC } \\
\text { Channel }\end{array}$ & $\begin{array}{l}\text { TC } \\
\text { Basin }\end{array}$ \\
\hline \%TOC & 0.1 & 0.1 & 0.3 & 2 & 1.4 & 2.2 & 1.6 & 1.3 & 1.6 & 3.7 \\
\hline Fipronils & $\mathbf{0}$ & $\mathbf{0}$ & $\mathbf{0}$ & $\mathbf{0}$ & $\mathbf{0}$ & 0.1 & 0.9 & 0.1 & 0.3 & 1.9 \\
\hline Pyrethroids & $\mathbf{0}$ & $\mathbf{0}$ & $\mathbf{0}$ & 0.8 & 1.1 & 4.7 & 32.8 & 12.6 & 10.9 & 124.6 \\
\hline PBDES & $\mathbf{0}$ & $\mathbf{0}$ & $\mathbf{0}$ & 1 & 0.2 & 3.6 & 6.1 & 3 & 2.3 & 15.8 \\
\hline इPAHs & NA & $\mathbf{0}$ & 25.7 & 162.7 & 170.8 & 660.9 & 371.3 & 277.6 & 515.7 & 1066.7 \\
\hline \multicolumn{11}{|c|}{ Surrogate Recoveries } \\
\hline DBOFP & & & & & 74 & & 67 & 54 & 67 & 71 \\
\hline PCB208 & 79 & 67 & 72 & 74 & 95 & 67 & 92 & 97 & 91 & 90 \\
\hline
\end{tabular}

Table 2.2 Concentrations (in ppb) for total fipronils, pyrethroids, PBDEs and PAHs from bulk sediment samples collected in Spring 2013. Percent total organic carbon was measured by SCCWRP prior to the analysis, and surrogate recoveries for each sample are reported. PAHs were not analyzed in the Mariner's Cove (MC) beach sample. 


\begin{tabular}{|c|c|c|c|c|c|c|c|c|c|c|}
\hline & MC Beach & VC Beach & FB Beach & CP Beach & CP Channel & CC Beach & CC Channel & TC Beach & TC Channel & TC Basin \\
\hline \multicolumn{11}{|l|}{ Compounds } \\
\hline $\begin{array}{c}\text { Fipronil } \\
\text { desulfinyl }\end{array}$ & ND & ND & ND & BDL & 0.02 & 0.06 & 0.22 & 0.06 & 0.09 & 0.42 \\
\hline Fipronil sulfide & ND & ND & ND & BDL & BDL & BDL & 0.16 & 0.03 & 0.04 & 0.31 \\
\hline Fipronil & ND & ND & ND & BDL & ND & BDL & BDL & BDL & ND & BDL \\
\hline $\begin{array}{l}\text { Fipronil } \\
\text { sulfone }\end{array}$ & ND & ND & ND & BDL & ND & BDL & 0.57 & BDL & 0.16 & 1.21 \\
\hline Bifenthrin & ND & ND & BDL & 0.84 & 1.08 & 2.82 & 8.84 & 3.82 & 5.49 & 27.95 \\
\hline Fenpropathrin & ND & ND & ND & ND & ND & ND & ND & ND & ND & ND \\
\hline $\begin{array}{c}\text { Lamda- } \\
\text { Cyhalothrin }\end{array}$ & ND & ND & ND & BDL & ND & BDL & 0.93 & 0.25 & 0.11 & 1.92 \\
\hline Permethrin & ND & ND & ND & BDL & ND & BDL & 15.10 & 6.76 & 3.82 & 72.95 \\
\hline Cyfluthrin & ND & ND & ND & BDL & ND & BDL & 3.18 & 1.05 & 0.60 & 13.90 \\
\hline Cypermethrin & ND & ND & ND & BDL & ND & BDL & 3.31 & BDL & 0.32 & 3.56 \\
\hline Esfenvalerate & ND & ND & ND & BDL & ND & 0.09 & BDL & BDL & BDL & 0.07 \\
\hline Deltamethrin & ND & ND & ND & BDL & ND & 1.37 & 1.46 & 0.40 & 0.56 & 4.25 \\
\hline Fipronils & 0 & $\mathbf{0}$ & $\mathbf{0}$ & $\mathbf{0}$ & 0.02 & 0.06 & 0.95 & 0.09 & 0.29 & 1.94 \\
\hline Pyrethroids & $\mathbf{0}$ & $\mathbf{0}$ & $\mathbf{0}$ & 0.84 & 1.08 & 4.65 & 32.82 & 12.28 & 10.90 & 124.59 \\
\hline
\end{tabular}

Table 2.3 Concentrations (in ng gdw ${ }^{-1}$ ) of four fipronils and eight pyrethroids measured in bulk sediment samples collected in Spring 2013. ND indicates that the compound was not detected. BDL indicates the compound was detected but was under the limit of quantitation for the method; these were not included in the calculation for total fipronils and pyrethroids. Numbers indicate the concentration of each compound detected, and total fipronils and pyrethroids can be found in the last two rows. 


\begin{tabular}{|c|c|c|c|c|c|c|c|c|c|c|}
\hline & MC Beach & VC Beach & FB Beach & CP Beach & CP Channel & CC Beach & CC Channel & TC Beach & TC Channel & TC Basin \\
\hline \multicolumn{11}{|c|}{ Compounds } \\
\hline BDE 15 & ND & ND & ND & ND & ND & ND & ND & ND & ND & 2.08 \\
\hline BDE 33 & ND & ND & ND & ND & ND & ND & ND & ND & ND & ND \\
\hline BDE 28 & ND & ND & ND & ND & ND & ND & ND & ND & ND & ND \\
\hline BDE 75 & ND & ND & ND & ND & ND & ND & ND & ND & ND & BDL \\
\hline BDE 49 & ND & ND & ND & BDL & ND & 0.21 & 0.32 & 0.18 & 0.26 & 0.90 \\
\hline BDE 47 & BDL & BDL & BDL & 0.28 & 0.14 & 0.88 & 1.47 & 0.82 & 0.48 & 3.13 \\
\hline BDE 66 & ND & ND & ND & ND & ND & ND & ND & ND & ND & 0.20 \\
\hline BDE 100 & ND & ND & ND & 0.09 & BDL & 0.36 & 0.62 & 0.27 & 0.28 & 1.18 \\
\hline BDE 119 & ND & ND & ND & ND & ND & ND & ND & ND & ND & ND \\
\hline BDE 99 & ND & BDL & BDL & 0.39 & BDL & 1.46 & 2.67 & 1.26 & 0.75 & 5.92 \\
\hline BDE 155 & ND & ND & ND & ND & ND & ND & BDL & ND & ND & 0.05 \\
\hline BDE 154 & ND & ND & ND & 0.05 & BDL & 0.20 & 0.36 & 0.19 & 0.15 & 0.77 \\
\hline BDE 153 & ND & ND & ND & 0.07 & BDL & 0.28 & 0.56 & 0.25 & 0.24 & 1.23 \\
\hline BDE 183 & ND & ND & ND & 0.14 & ND & 0.20 & 0.14 & BDL & 0.17 & 0.38 \\
\hline PBDEs & $\mathbf{0}$ & $\mathbf{0}$ & $\mathbf{0}$ & 1.02 & 0.17 & 3.59 & 6.14 & 2.96 & 2.33 & 15.82 \\
\hline
\end{tabular}

Table 2.4 Concentrations (in ng gdw ${ }^{-1}$ ) of 14 PBDEs from sediment samples collected in Spring 2013. ND indicates that the compound was not detected. BDL indicates the compound was detected but was below the limit of quantitation for the method; these were not included in the calculation for total PBDEs. Numbers indicate the concentration of each compound detected, and the sum of the PBDEs can be found in the last row. Congeners 47 and 99 were the most prevalent in samples from the bay. 


\begin{tabular}{|c|c|c|c|c|c|c|c|c|c|}
\hline Site & VC Beach & FB Beach & CP Beach & CP Channel & CC Beach & CC Channel & TC Beach & TC Channel & TC Basin \\
\hline $\begin{array}{l}\Sigma \text { LLOW MW } \\
\text { PAH }\end{array}$ & 0 & 1.4 & 20.8 & 21.5 & 42.6 & 37.2 & 21.4 & 35.0 & 100.9 \\
\hline 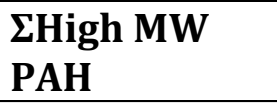 & 0 & 24.3 & 141.9 & 149.3 & 618.3 & 334.1 & 256.2 & 480.7 & 965.8 \\
\hline इPAHs & $\mathbf{0}$ & 25.7 & 162.7 & 170.8 & 660.9 & 371.3 & 277.6 & 515.7 & 1066.7 \\
\hline$\Sigma 2$-ring PAHs & 0 & 0.5 & 5.6 & 11.5 & 4.1 & 6.9 & 3.6 & 4.9 & 8.5 \\
\hline$\Sigma 3$-ring PAHs & 0 & 0.9 & 15.2 & 10.0 & 38.5 & 30.9 & 17.8 & 30.1 & 94.8 \\
\hline 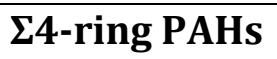 & 0 & 11.5 & 62.7 & 62.6 & 266.4 & 152.7 & 114.6 & 194.1 & 456.8 \\
\hline 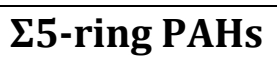 & 0 & 9.3 & 63.7 & 69.9 & 283.8 & 144.9 & 108.2 & 228.8 & 396.7 \\
\hline इ6-ring PAHs & 0 & 2.5 & 15.5 & 16.8 & 68.1 & 36.0 & 33.4 & 57.8 & 110.0 \\
\hline
\end{tabular}

Table 2.5 Total PAH concentrations (in ppb) for bulk sediment samples collected in Spring 2013. Total PAHs were separated into high and low molecular weight compounds, with high molecular weight compounds defined as those with a MW $>200$. Total PAHs also were separated into 2-, 3-, 4-, 5-, and 6-ring compounds. 


\begin{tabular}{|l|c|c|c|}
\hline Season & Site & Location & IPAHs \\
\hline Summer & MC & Beach & 30.86 \\
\hline Summer & VC & Beach & 42.68 \\
\hline Summer & FB & Beach & 42.95 \\
\hline Summer & CP & Beach & 75.63 \\
\hline Summer & CC & Beach & 125.14 \\
\hline Summer & TC & Beach & 207.43 \\
\hline Fall & MC & Beach & 65.19 \\
\hline Fall & VC & Beach & 144.90 \\
\hline Fall & FB & Beach & 118.15 \\
\hline Fall & CP & Beach & 105.73 \\
\hline Fall & CC & Beach & 390.43 \\
\hline Fall & TC & Beach & 152.98 \\
\hline Fall & MC & Beach 1-dpr & 70.92 \\
\hline Fall & VC & Beach 1-dpr & 66.09 \\
\hline Fall & FB & Beach 1-dpr & 65.76 \\
\hline Fall & CP & Beach 1-dpr & 147.53 \\
\hline Fall & CC & Beach 1-dpr & 511.41 \\
\hline Fall & TC & Beach 1-dpr & 135.55 \\
\hline Fall & FB & Beach 4-dpr & 135.13 \\
\hline Fall & CC & Beach 4-dpr & 435.68 \\
\hline Fall & TC & Beach 4-dpr & 285.27 \\
\hline Fall & MC & Channel & 126.02 \\
\hline
\end{tabular}




\begin{tabular}{|c|c|c|c|}
\hline Fall & VC & Channel & 78.00 \\
\hline Fall & CP & Channel & 319.27 \\
\hline Fall & CC & Channel & 361.00 \\
\hline Fall & TC & Channel & 588.48 \\
\hline Winter & MC & Beach & 52.22 \\
\hline Winter & VC & Beach & 39.05 \\
\hline Winter & FB & Beach & 47.93 \\
\hline Winter & CP & Beach & 132.93 \\
\hline Winter & CC & Beach & 421.90 \\
\hline Winter & TC & Beach & 338.02 \\
\hline Winter & MC & Channel & 80.23 \\
\hline Winter & FB & Channel & 95.53 \\
\hline Winter & CP & Channel & 255.17 \\
\hline Winter & CC & Channel & 272.10 \\
\hline Winter & TC & Channel & 341.75 \\
\hline Spring & MC & Beach & 50.14 \\
\hline Spring & VC & Beach & 38.18 \\
\hline Spring & FB & Beach & 44.91 \\
\hline Spring & CP & Beach & 40.21 \\
\hline Spring & CC & Beach & 189.45 \\
\hline Spring & TC & Beach & 388.48 \\
\hline Spring & MC & Channel & 152.17 \\
\hline Spring & CP & Channel & 151.71 \\
\hline Spring & CC & Channel & 443.85 \\
\hline Spring & TC & Channel & 554.43 \\
\hline
\end{tabular}




\begin{tabular}{|c|c|c|c|}
\hline Spring & TC-B & Basin & 1111.89 \\
\hline Spring '14 & RC Bank & Beach & 344.20 \\
\hline Spring '14 & RC Bed & Channel & 123.81 \\
\hline Spring '14 & Quivira Basin & Channel & 484.44 \\
\hline Spring '14 & Dana Landing & Channel & 242.40 \\
\hline
\end{tabular}

Table 2.6 Total PAHs (in ppb) measured at each site for each season. Seasons includes Summer 2012-Spring 2013 as well as Spring 2014. Location includes beach samples from one and four days post rainfall during Fall 2012. 


\begin{tabular}{|l|c|c|c|c|c|c|}
\hline \multicolumn{1}{|c|}{ Site } & MC & VC & FB & CP & CC & TC \\
\hline \multicolumn{1}{|c|}{ PAHs } & Beach & Beach & Beach & Beach & Beach & Beach \\
\hline IPAHs & & & & & & \\
\hline Naphthalene & $\mathbf{3 0 . 8 6}$ & $\mathbf{4 2 . 6 8}$ & $\mathbf{4 2 . 9 5}$ & $\mathbf{7 5 . 6 3}$ & $\mathbf{1 2 5 . 1 4}$ & $\mathbf{2 0 7 . 4 3}$ \\
\hline Fluorene & 5.58 & 8.98 & 7.44 & 16.29 & 17.15 & 23.56 \\
\hline Phenanthrene & 7.56 & 8.73 & 7.19 & 12.65 & 11.30 & 22.5 \\
\hline Anthracene & 8.76 & 6.95 & 8.85 & 13.25 & 20.32 & 32.42 \\
\hline Pyrenene & 1.19 & 1.79 & 1.99 & 0.72 & 3.54 & 6.12 \\
\hline Benzo[a]anthracene & 2.19 & 3.95 & 4.34 & 12.35 & 23.67 & 33.42 \\
\hline Chrysene & 2.80 & 7.40 & 6.45 & 6.97 & 15.93 & 19.94 \\
\hline Benzo[b]fluoranthene & 0.91 & 1.69 & 1.71 & 10.06 & 11.84 & 16.37 \\
\hline Benzo[k]fluoranthene & 0.68 & 0.00 & 1.42 & 3.03 & 4.29 & 14.32 \\
\hline Benzo[a]pyrene & 1.01 & 2.99 & 3.10 & 5.09 & 10.33 & 14.32 \\
\hline Dibenzo[a,h]anthracene & 0.54 & 0.23 & 1.33 & 0.27 & 1.70 & 15.66 \\
\hline Benzo[g,h,i]perylene & 0.00 & 0.00 & 0.00 & 0.00 & 0.00 & 0 \\
\hline Indeno[1,2,3-c,d]pyrene & 0.00 & 0.00 & 0.00 & 0.00 & 0.00 & 0 \\
\hline
\end{tabular}

Table 2.7 Concentrations (in ppb) of 13 PAHs measured in sediment samples collected from the beach in Summer 2012. Total PAHs are in bold. 


\begin{tabular}{|c|c|c|c|c|c|c|c|c|c|c|c|c|c|c|c|}
\hline \multirow{2}{*}{$\begin{array}{l}\text { Site } \\
\text { Location }\end{array}$} & \multicolumn{2}{|l|}{ MC } & \multicolumn{2}{|l|}{ VC } & \multicolumn{3}{|l|}{ FB } & \multicolumn{2}{|l|}{ CP } & \multicolumn{3}{|l|}{ CC } & \multicolumn{3}{|l|}{ TC } \\
\hline & Beach & $\begin{array}{l}\text { Beach } \\
\text { 1-DPR }\end{array}$ & Beach & $\begin{array}{l}\text { Beach } \\
\text { 1-DPR }\end{array}$ & Beach & $\begin{array}{l}\text { Beach } \\
\text { 1-DPR }\end{array}$ & $\begin{array}{l}\text { Beach } \\
\text { 4-DPR }\end{array}$ & Beach & $\begin{array}{l}\text { Beach } \\
\text { 1-DPR }\end{array}$ & Beach & $\begin{array}{l}\text { Beach } \\
\text { 1-DPR }\end{array}$ & $\begin{array}{l}\text { Beach } \\
\text { 4-DPR }\end{array}$ & Beach & $\begin{array}{l}\text { Beach } \\
\text { 1-DPR }\end{array}$ & $\begin{array}{l}\text { Beach } \\
\text { 4-DPR }\end{array}$ \\
\hline \multicolumn{16}{|l|}{ PAHs } \\
\hline ¿PAHs & 65.19 & 70.92 & 144.90 & 66.09 & 118.15 & 65.76 & 135.13 & 105.73 & 147.53 & 390.43 & 511.41 & 435.68 & 152.98 & 135.55 & 285.27 \\
\hline Naphthalene & 12.57 & 13.14 & 12.21 & 12.49 & 11.42 & 11.86 & 43.01 & 10.72 & 8.92 & 9.94 & 39.65 & 79.51 & 11.30 & 36.00 & 35.41 \\
\hline Fluorene & 39.43 & 42.19 & 42.12 & 38.27 & 39.41 & 39.30 & 34.74 & 35.05 & 54.47 & 33.58 & 86.95 & 41.43 & 62.04 & 48.58 & 58.33 \\
\hline Phenanthrene & 3.25 & 3.24 & 10.56 & 3.02 & 13.37 & 3.44 & 11.12 & 11.42 & 12.82 & 28.29 & 37.08 & 28.19 & 15.48 & 5.28 & 36.77 \\
\hline Anthracene & 0.37 & 0.42 & 5.10 & 0.46 & 7.90 & 0.43 & 4.01 & 6.36 & 7.62 & 11.85 & 0.13 & 11.15 & 7.26 & 1.03 & 2.14 \\
\hline Pyrenene & 1.63 & 3.42 & 14.16 & 3.66 & 11.42 & 2.66 & 11.63 & 9.13 & 12.48 & 68.49 & 81.58 & 74.66 & 14.98 & 14.46 & 55.46 \\
\hline Benzo[a]anthracene & 4.20 & 4.46 & 14.20 & 4.26 & 12.39 & 3.94 & 7.70 & 9.37 & 12.55 & 34.80 & 37.86 & 37.67 & 12.00 & 7.61 & 14.89 \\
\hline Chrysene & 0.41 & 0.00 & 5.31 & 1.19 & 11.44 & 0.00 & 7.63 & 5.68 & 8.75 & 39.69 & 40.61 & 42.40 & 7.35 & 4.46 & 16.45 \\
\hline Benzo[b]fluoranthene & 1.13 & 0.00 & 13.14 & 0.67 & 7.60 & 1.16 & 6.16 & 5.70 & 9.60 & 45.59 & 42.98 & 15.72 & 8.48 & 2.71 & 12.70 \\
\hline Benzo[k]fluoranthene & 1.67 & 2.40 & 16.16 & 2.46 & 9.38 & 1.98 & 10.09 & 7.04 & 10.42 & 36.59 & 35.89 & 38.52 & 9.60 & 6.27 & 16.05 \\
\hline Benzo[a]pyrene & 0.75 & 1.66 & 11.76 & 0.23 & 5.28 & 1.01 & 2.15 & 5.29 & 9.92 & 35.51 & 61.11 & 1.10 & 8.17 & 6.09 & 3.52 \\
\hline Dibenzo[a,h]anthracene & 0.00 & 0.00 & 0.00 & 0.00 & 0.00 & 0.00 & 0.00 & 0.00 & 0.00 & 0.00 & 0.00 & 3.04 & 0.00 & 0.00 & 0.00 \\
\hline Benzo[g,h,i]perylene & 0.00 & 0.00 & 8.96 & 0.00 & 0.00 & 0.00 & 0.00 & 0.00 & 0.00 & 46.11 & 47.57 & 62.32 & 0.00 & 4.45 & 33.58 \\
\hline Indeno[1,2,3-c,d]pyrene & 0.00 & 0.00 & 0.00 & 0.00 & 0.00 & 0.00 & 0.00 & 0.00 & 0.00 & 0.00 & 0.00 & 0.00 & 0.00 & 0.00 & 0.00 \\
\hline
\end{tabular}

Table 2.8 Concentrations (in ppb) of 13 PAHs measured in sediment samples collected from the beach in Fall 2012.

Samples from one and four days after the first rainfall of the season are included. Total PAHs are in bold. 


\begin{tabular}{|l|r|r|r|r|r|}
\hline Site & \multicolumn{1}{|c|}{ MC } & \multicolumn{1}{c|}{ VC } & \multicolumn{1}{c|}{ CP } & \multicolumn{1}{c|}{ CC } & \multicolumn{1}{c|}{ TC } \\
\hline Location & \multicolumn{1}{c|}{ Channel } & \multicolumn{1}{c|}{ Channel } & \multicolumn{1}{c|}{ Channel } & \multicolumn{1}{c|}{ Channel } & \multicolumn{1}{c|}{ Channel } \\
\hline PAHs & & & & & \\
\hline SPAHs & $\mathbf{1 2 6 . 0 2}$ & $\mathbf{7 8 . 0 0}$ & $\mathbf{3 1 9 . 2 7}$ & $\mathbf{3 6 1 . 0 0}$ & $\mathbf{5 8 8 . 4 8}$ \\
\hline Naphthalene & 54.17 & 39.75 & 93.98 & 105.09 & 118.81 \\
\hline Fluorene & 14.99 & 11.22 & 95.09 & 27.26 & 114.75 \\
\hline Phenanthrene & 9.86 & 5.35 & 14.66 & 22.88 & 20.52 \\
\hline Anthracene & 2.52 & 1.40 & 4.73 & 4.52 & 5.61 \\
\hline Pyrenene & 15.85 & 6.63 & 19.94 & 65.62 & 69.26 \\
\hline Benzo[a]anthracene & 7.93 & 5.20 & 32.22 & 11.71 & 34.76 \\
\hline Chrysene & 8.86 & 2.09 & 13.78 & 29.41 & 44.21 \\
\hline Benzo[b]fluoranthene & 0.20 & 1.89 & 9.49 & 11.45 & 32.60 \\
\hline Benzo[k]fluoranthene & 7.73 & 3.87 & 15.55 & 30.28 & 45.72 \\
\hline Benzo[a]pyrene & 2.06 & 0.63 & 2.54 & 2.71 & 7.86 \\
\hline Dibenzo[a,h]anthracene & 0.00 & 0.00 & 0.00 & 0.00 & 0.00 \\
\hline Benzo[g,h,i]perylene & 1.97 & 0.00 & 17.30 & 55.82 & 94.42 \\
\hline Indeno[1,2,3-c,d]pyrene & 0.00 & 0.00 & 0.00 & 0.00 & 0.00 \\
\hline
\end{tabular}

Table 2.9 Concentrations (in ppb) of 13 PAHs measured in sediment samples collected from the channel in Fall 2012. Total PAHs are in bold. 


\begin{tabular}{|c|c|c|c|c|c|c|c|c|c|c|c|}
\hline \multirow{2}{*}{$\begin{array}{l}\text { Site } \\
\text { Location }\end{array}$} & \multicolumn{2}{|l|}{ MC } & \multirow{2}{*}{$\frac{\text { VC }}{\text { Beach }}$} & \multicolumn{2}{|l|}{ FB } & \multicolumn{2}{|l|}{ CP } & \multicolumn{2}{|l|}{ CC } & \multicolumn{2}{|l|}{ TC } \\
\hline & Beach & Channel & & Beach & Channel & Beach & Channel & Beach & Channel & Beach & Channel \\
\hline \multicolumn{12}{|l|}{ PAHs } \\
\hline ¿PAHs & 52.22 & 80.23 & 39.05 & 47.93 & 95.53 & 132.93 & 255.17 & 421.90 & 272.10 & 338.02 & 341.75 \\
\hline Naphthalene & 8.90 & 11.38 & 12.83 & 10.76 & 12.23 & 19.26 & 17.26 & 11.88 & 15.94 & 12.89 & 21.20 \\
\hline Fluorene & 11.38 & 16.02 & 10.76 & 11.84 & 4.44 & 16.30 & 19.68 & 19.17 & 13.31 & 23.98 & 9.53 \\
\hline Phenanthrene & 13.26 & 16.34 & 3.25 & 4.29 & 15.87 & 14.65 & 25.08 & 42.61 & 25.94 & 29.52 & 27.12 \\
\hline Anthracene & 1.37 & 2.94 & 1.01 & 1.15 & 3.85 & 3.00 & 4.09 & 6.06 & 4.18 & 5.82 & 4.06 \\
\hline Pyrenene & 5.58 & 12.96 & 2.43 & 6.77 & 9.16 & 31.40 & 61.31 & 111.06 & 66.15 & 87.14 & 82.41 \\
\hline Benzo[a]anthracene & 6.92 & 9.15 & 4.45 & 6.56 & 16.00 & 9.12 & 22.28 & 27.60 & 23.64 & 22.75 & 32.53 \\
\hline Chrysene & 1.85 & 11.02 & 0.80 & 0.00 & 6.04 & 15.79 & 34.26 & 55.23 & 23.75 & 32.76 & 30.35 \\
\hline Benzo[b]fluoranthene & 0.00 & 1.19 & 0.94 & 1.81 & 32.06 & 11.34 & 14.73 & 29.77 & 16.16 & 38.28 & 21.75 \\
\hline Benzo[k]fluoranthene & 2.31 & 3.60 & 2.06 & 3.64 & 5.26 & 10.25 & 24.74 & 40.69 & 25.05 & 27.35 & 36.12 \\
\hline Benzo[a]pyrene & 0.15 & 0.23 & 0.94 & 1.14 & 0.16 & 0.42 & 11.83 & 8.02 & 10.78 & 3.13 & 12.10 \\
\hline Dibenzo[a,h]anthracene & 0.00 & 0.00 & 0.00 & 0.00 & 0.00 & 0.00 & 0.00 & 0.00 & 0.00 & 0.00 & 0.00 \\
\hline Benzo[g,h,i]perylene & 0.59 & 0.00 & 0.00 & 0.00 & 0.00 & 7.08 & 37.05 & 69.84 & 47.22 & 54.42 & 64.60 \\
\hline Indeno[1,2,3-c,d]pyrene & 0.00 & 0.00 & 0.00 & 0.00 & 0.00 & 0.00 & 0.00 & 0.00 & 0.00 & 0.00 & 0.00 \\
\hline
\end{tabular}

Table 2.10 Concentrations (in ppb) of $13 \mathrm{PAHs}$ measured in sediment samples collected from the beach and channel in Winter 2012-13. Total PAHs are in bold. 


\begin{tabular}{|c|c|c|c|c|c|c|c|c|c|c|c|}
\hline \multirow{2}{*}{$\begin{array}{l}\text { Site } \\
\text { Location }\end{array}$} & \multicolumn{2}{|l|}{ MC } & \multirow{2}{*}{$\begin{array}{l}\text { VC } \\
\text { Beach }\end{array}$} & \multirow{2}{*}{$\begin{array}{l}\text { FB } \\
\text { Beach }\end{array}$} & \multicolumn{2}{|l|}{$\mathbf{C P}$} & \multicolumn{2}{|l|}{ CC } & \multicolumn{3}{|l|}{ TC } \\
\hline & Beach & Channel & & & Beach & Channel & Beach & Channel & Beach & Channel & Basin \\
\hline \multicolumn{12}{|l|}{ PAHs } \\
\hline ¿PAHs & 50.14 & 152.17 & 38.18 & 44.91 & 40.21 & 151.71 & 189.45 & 443.85 & 388.48 & 554.43 & 1111.89 \\
\hline Naphthalene & 9.20 & 31.30 & 9.38 & 11.42 & 7.53 & 30.47 & 9.67 & 55.99 & 9.59 & 67.59 & 103.06 \\
\hline Fluorene & 10.86 & 6.22 & 8.67 & 6.53 & 9.18 & 7.93 & 12.44 & 10.18 & 23.45 & 16.33 & 12.22 \\
\hline Phenanthrene & 6.08 & 13.42 & 6.31 & 6.89 & 6.44 & 15.19 & 17.05 & 42.68 & 49.58 & 41.24 & 77.52 \\
\hline Anthracene & 1.16 & 2.55 & 1.29 & 1.31 & 1.48 & 2.70 & 3.12 & 5.15 & 9.65 & 3.68 & 12.25 \\
\hline Pyrenene & 4.61 & 36.04 & 3.59 & 6.47 & 11.66 & 29.36 & 45.34 & 108.47 & 84.33 & 127.55 & 298.70 \\
\hline Benzo[a]anthracene & 5.38 & 16.85 & 4.70 & 4.68 & 10.53 & 18.20 & 20.86 & 27.46 & 35.60 & 48.44 & 83.68 \\
\hline Chrysene & 0.00 & 0.00 & 0.00 & 3.73 & 4.46 & 10.11 & 19.42 & 43.77 & 36.23 & 51.16 & 108.00 \\
\hline Benzo[b]fluoranthene & 1.18 & 10.34 & 0.76 & 1.45 & 3.90 & 8.79 & 33.78 & 31.15 & 23.38 & 36.82 & 93.26 \\
\hline Benzo[k]fluoranthene & 3.06 & 13.06 & 2.46 & 3.64 & 3.67 & 14.84 & 18.69 & 39.96 & 28.26 & 53.72 & 103.29 \\
\hline Benzo[a]pyrene & 9.23 & 13.27 & 1.04 & 0.68 & 8.95 & 11.23 & 7.89 & 3.78 & 45.40 & 8.92 & 26.71 \\
\hline Dibenzo[a,h]anthracene & 0.00 & 0.00 & 0.00 & 0.00 & 0.00 & 0.00 & 0.00 & 0.00 & 0.00 & 0.00 & 1.70 \\
\hline Benzo[g,h,i]perylene & 0.00 & 14.32 & 0.00 & 0.00 & 0.00 & 7.98 & 18.11 & 75.29 & 43.05 & 99.02 & 243.07 \\
\hline Indeno[1,2,3-c,d]pyrene & 0.00 & 0.00 & 0.00 & 0.00 & 0.00 & 0.00 & 0.00 & 0.00 & 0.00 & 0.00 & 0.00 \\
\hline
\end{tabular}

Table 2.11 Concentrations (in ppb) of 13 PAHs measured in sediment samples collected from the beach, channel and basin in Spring 2013. Total PAHs are in bold. 


\begin{tabular}{|l|c|c|c|c|}
\hline Site & Quivira Basin & Dana Landing & Rose Creek Bed & Rose Creek Bank \\
\hline Location & Channel & Channel & Channel & Beach \\
\hline PAHs & & & & \\
\hline LPAHs & $\mathbf{4 8 4 . 4 4}$ & $\mathbf{2 4 2 . 4 0}$ & $\mathbf{1 2 3 . 8 1}$ & $\mathbf{3 4 4 . 2 0}$ \\
\hline Naphthalene & 12.99 & 0.00 & 9.26 & 20.41 \\
\hline Fluorene & 41.99 & 62.57 & 23.70 & 38.03 \\
\hline Phenanthrene & 20.56 & 14.66 & 10.21 & 26.78 \\
\hline Anthracene & 14.19 & 4.88 & 4.41 & 5.80 \\
\hline Pyrenene & 49.34 & 24.33 & 24.19 & 86.01 \\
\hline Benzo[a]anthracene & 51.08 & 15.67 & 6.97 & 18.60 \\
\hline Chrysene & 91.71 & 15.31 & 7.95 & 28.71 \\
\hline Benzo[b]fluoranthene & 79.59 & 25.93 & 4.26 & 19.77 \\
\hline Benzo[k]fluoranthene & 62.95 & 18.53 & 9.88 & 30.66 \\
\hline Benzo[a]pyrene & 4.14 & 32.13 & 5.03 & 1.24 \\
\hline Dibenzo[a,h]anthracene & 0.73 & 0.00 & 0.00 & 0.00 \\
\hline Benzo[g,h,i]perylene & 55.17 & 28.39 & 17.95 & 68.19 \\
\hline Indeno[1,2,3-c,d]pyrene & 0.00 & 0.00 & 0.00 & 0.00 \\
\hline
\end{tabular}

Table 2.12 Concentrations (in ppb) of 13 PAHs measured in sediment samples collected from the beach and channel in Spring 2014. Total PAHs are in bold. 


\begin{tabular}{|c|c|c|c|c|c|c|}
\hline Year & Season & Site & Location & Cu (ppm) & Pb (ppm) & Zn (ppm) \\
\hline 2012 & Summer & MC & Beach & 0.4 & 1.1 & 5.1 \\
\hline 2012 & Summer & VC & Beach & 2.3 & 2.7 & 12.6 \\
\hline 2012 & Summer & FB & Beach & 5.1 & & 19.4 \\
\hline 2012 & Summer & CP & Beach & 5.2 & 4.6 & 30.1 \\
\hline 2012 & Summer & CC & Beach & 4.9 & & 17.6 \\
\hline 2012 & Summer & TC & Beach & 11.8 & 13 & 51.3 \\
\hline 2012 & Fall & MC & Beach & 0.7 & & 4.3 \\
\hline 2012 & Fall & VC & Beach & 2.6 & & 8.8 \\
\hline 2012 & Fall & FB & Beach & 3.7 & & 12.4 \\
\hline 2012 & Fall & CP & Beach & 2.5 & & 7.2 \\
\hline 2012 & Fall & CC & Beach & 14.3 & & 56.7 \\
\hline 2012 & Fall & TC & Beach & 2.8 & & 22.4 \\
\hline 2012 & Fall & MC 1d-post rain & Beach & 1.8 & & 9.6 \\
\hline 2012 & Fall & VC 1d-post rain & Beach & 2.7 & & 11 \\
\hline 2012 & Fall & FB 1d-post rain & Beach & 5.6 & & 17.8 \\
\hline 2012 & Fall & CP 1d-post rain & Beach & 3.2 & & 17.4 \\
\hline 2012 & Fall & CC 1d-post rain & Beach & 11.5 & & 53.4 \\
\hline 2012 & Fall & TC 1d-post rain & Beach & 5.4 & & 29.9 \\
\hline 2012 & Fall & FB 4d-post rain & Beach & 11.9 & & 48.2 \\
\hline 2012 & Fall & CC 4d-post rain & Beach & 19.4 & & 80.5 \\
\hline 2012 & Fall & TC 4d-post rain & Beach & 14.7 & & 98.7 \\
\hline 2012 & Fall & MC & Channel & 7.4 & & 46.6 \\
\hline 2012 & Fall & VC & Channel & 6.4 & & 36.6 \\
\hline 2012 & Fall & CP & Channel & 40.4 & & 161.9 \\
\hline 2012 & Fall & CC & Channel & 23.6 & & 94.4 \\
\hline 2012 & Fall & TC & Channel & 48 & & 180.3 \\
\hline
\end{tabular}




\begin{tabular}{|c|c|c|c|c|c|c|}
\hline 2013 & Winter & $M C$ & Beach & 1.2 & & 10.5 \\
\hline 2013 & Winter & VC & Beach & 1.4 & & 26.3 \\
\hline 2013 & Winter & FB & Beach & 7 & & 24.4 \\
\hline 2013 & Winter & $\mathrm{CP}$ & Beach & 15.8 & & 64.5 \\
\hline 2013 & Winter & $\mathrm{CC}$ & Beach & 27.4 & & 131.3 \\
\hline 2013 & Winter & $\mathrm{TC}$ & Beach & 23.7 & & 110.3 \\
\hline 2013 & Winter & $M C$ & Channel & 10 & & 48.3 \\
\hline 2013 & Winter & FB & Channel & 9.7 & & 60.6 \\
\hline 2013 & Winter & $\mathrm{CP}$ & Channel & 34.4 & & 148.6 \\
\hline 2013 & Winter & $\mathrm{CC}$ & Channel & 28.3 & & 139.9 \\
\hline 2013 & Winter & $\mathrm{TC}$ & Channel & 42.7 & & 174.6 \\
\hline 2013 & Spring & $M C$ & Beach & 1.5 & 1.6 & 11.5 \\
\hline 2013 & Spring & VC & Beach & 1.9 & 3.2 & 16 \\
\hline 2013 & Spring & FB & Beach & 8.1 & & 32.2 \\
\hline 2013 & Spring & $\mathrm{CP}$ & Beach & 6.8 & 6 & 38.1 \\
\hline 2013 & Spring & $\mathrm{CC}$ & Beach & 10.5 & & 49.6 \\
\hline 2013 & Spring & $\mathrm{TC}$ & Beach & 18.3 & 22.4 & 89.4 \\
\hline 2013 & Spring & MC & Channel & 6.8 & 5 & 46.2 \\
\hline 2013 & Spring & $\mathrm{CP}$ & Channel & 36.3 & 30.6 & 141.5 \\
\hline 2013 & Spring & $\mathrm{CC}$ & Channel & 38.5 & & 155.7 \\
\hline 2013 & Spring & $\mathrm{TC}$ & Channel & 48.9 & 60.5 & 191.7 \\
\hline 2013 & Spring & $\mathrm{TC}$ & Basin & 64 & 58.6 & 258.7 \\
\hline 2014 & Spring & MB Channel & Channel & 0 & 0 & 18.9 \\
\hline 2014 & Spring & $\mathrm{MC}$ & Channel & 17.7 & 14 & 73.1 \\
\hline 2014 & Spring & Quivira Basin & Channel & 88.6 & 17.7 & 99.6 \\
\hline 2014 & Spring & Dana Landing & Channel & 77.3 & 24.8 & 160.6 \\
\hline 2014 & Spring & VC & Channel & 9 & 5.7 & 65.7 \\
\hline 2014 & Spring & FB & Channel & 43.8 & 51.2 & 167.1 \\
\hline
\end{tabular}




\begin{tabular}{|c|c|c|c|c|c|c|}
\hline 2014 & Spring & RC & Creek Beach & 12.2 & 14.3 & 82.4 \\
\hline 2014 & Spring & RC & Creek Channel & 0 & 13.7 & 325.4 \\
\hline 2014 & Spring & RC & Channel & 38 & 39.8 & 141 \\
\hline 2014 & Spring & CC & Channel & 31.5 & 33.4 & 129.1 \\
\hline 2014 & Spring & TC & Beach & 34.6 & 23.8 & 217.4 \\
\hline & & & ERL & 34 & 46.7 & 150 \\
\hline
\end{tabular}

Table 2.13 Concentrations (in ppm) of copper, lead and zinc from samples collected in 2012, 2013 and 2014. The season, site and location of the samples are indicated, and samples that exceed EPA effects range low (ERL) thresholds are highlighted in dark grey. In addition to the four sites sampled in 2012-2013, Cudahy Creek, Rose Creek, Fiesta Bay, Dana Landing, Quivira Basin and Mission Bay Channel were also sampled in 2014. ND indicates the metals were not detected at that site. 


\begin{tabular}{|c|c|c|c|c|c|c|c|c|c|c|c|c|}
\hline & $\begin{array}{l}\text { Temp at } \\
\text { Bottom }\end{array}$ & $\begin{array}{l}\text { Salinity } \\
\text { at } \\
\text { Bottom }\end{array}$ & $\begin{array}{l}\text { Rainfall } \\
\text { in } \\
\text { Season }\end{array}$ & $\begin{array}{l}\text { Median } \\
\text { Grain } \\
\text { Size }\end{array}$ & $\begin{array}{l}\text { Percent } \\
\text { Fine } \\
\text { Fraction }\end{array}$ & $\begin{array}{l}\text { Total } \\
\text { Pyrethroids }\end{array}$ & $\begin{array}{l}\text { Total } \\
\text { Fipronils }\end{array}$ & $\begin{array}{l}\text { Total } \\
\text { PBDEs }\end{array}$ & $\begin{array}{l}\text { Total } \\
\text { PAHs }\end{array}$ & Cu (ppm) & $\begin{array}{l}\text { Pb } \\
\text { (ppm) }\end{array}$ & Zn (ppm) \\
\hline $\begin{array}{l}\text { Temp at } \\
\text { Bottom }\end{array}$ & 1 & $0.36^{* * * *}$ & $-0.70^{* * * *}$ & $0.17^{* *}$ & $-0.27^{* * * *}$ & & & & & & & \\
\hline $\begin{array}{l}\text { Salinity at } \\
\text { Bottom }\end{array}$ & & 1 & $-0.24 * * * *$ & $0.12 *$ & -0.07 & & & & & & & \\
\hline $\begin{array}{l}\text { Rainfall in } \\
\text { Season }\end{array}$ & & & 1 & $-0.25^{* * * *}$ & $0.35^{* * * *}$ & & & & & & & \\
\hline $\begin{array}{l}\text { Median } \\
\text { Grain Size }\end{array}$ & & & & 1 & $-0.92 * * * *$ & $-0.67^{* * * *}$ & $-0.63^{* * * *}$ & $-0.79 * * * *$ & $-0.84 * * * *$ & $-0.93^{* * * *}$ & $-0.88^{* * * *}$ & $-0.96 * * * *$ \\
\hline $\begin{array}{l}\text { Percent } \\
\text { Fine } \\
\text { Fraction }\end{array}$ & & & & & 1 & $0.64 * * * *$ & $0.60 * * * *$ & $0.79 * * * *$ & $0.83^{* * * *}$ & $0.9 * * * *$ & $.84 * * * *$ & $0.94 * * * *$ \\
\hline $\begin{array}{l}\text { Total } \\
\text { Pyrethroids }\end{array}$ & & & & & & 1 & & & & & & \\
\hline $\begin{array}{l}\text { Total } \\
\text { Fipronils }\end{array}$ & & & & & & & 1 & & & & & \\
\hline Total PBDEs & & & & & & & & 1 & & & & \\
\hline Total PAHs & & & & & & & & & 1 & & & \\
\hline Cu (ppm) & & & & & & & & & & 1 & & \\
\hline $\mathrm{Pb}$ (ppm) & & & & & & & & & & & 1 & \\
\hline $\mathrm{Zn}$ (ppm) & & & & & & & & & & & & 1 \\
\hline
\end{tabular}

Table 2.14 Pearson product-moment correlation scores for sediment characteristics and contaminant concentrations. ${ }^{*} \mathrm{p}<0.1,{ }^{* *} \mathrm{p}<0.05,{ }^{* * *} \mathrm{p}<0.01,{ }^{* * * *} \mathrm{p}<0.001$. 


\section{6 - References}

Amweg, E.L., Weston, D.P., You, J. and Lydy, M.J. Pyrethroid insecticides and sediment toxicity in urban creeks from California and Tennessee. Environmental Science and Technology 40: 1700-1706.

Baird, S., Garrison, A., Jones, J., Avanta, J., Bringolf, R. and Black, M. 2013. Enantioselective toxicity and bioaccumulation of fipronil in fathead minnows (Pimpehales promelas) following water and sediment exposures. Environmental Toxicology and Chemistry 32: 222-227.

Bay, S., Schiff, K., Greenstein, D., Tiefenthaler, L. 1998. Stormwater runoff effects on Santa Monica Bay: Toxicity, sediment quality, and benthic community impacts. Proceedings, California and the World Ocean '97, San Diego, CA, USA, March 2427 1997. 900-921.

Beggel, S., Connon, R., Werner, I. and Geist, J. 2011. Changes in gene transcription and whole organism responses in larval fathead minnow (Pimephales promelas) following short-term exposure to the synthetic pyrethroid bifenthrin. Aquatic Toxicology 105: 180188.

Brown, J.S., Stein, E.D., Ackerman, D., Dorsey, J.H., Lyon, J. and Carter, P.M. 2013. Metals and bacteria partitioning to various size particles in Ballona Creek storm water runoff. Environmental Toxicology and Chemistry 32: 320-328.

Davis, A.P., Shokouhian, M. and Ni, S. 2001. Loading estimates of lead, copper, cadmium and zinc in urban runoff from specific sources. Chemosphere 44: 997-1009.

Dodder, N.G., Maruya, K.A., Lauenstein, G.G., Ramirez, J., Ritter, K.J. and Schiff, K. 2012. Distribution and sources of polybrominated diphenyl ethers in the Southern California Bight. Environmental Toxicology and Chemistry 31: 2239-2245.

Duong, C.N., Schlenk, D., Chang, N.I. and Kim, S.D. The effect of particle size on the bioavailability of estrogenic chemicals from sediments. Chemosphere 76: 395-401.

Eggleton, J. and Thomas, K.V. 2004. A review of factors affecting the release and bioavailability of contaminants during sediment disturbance events. Environment International 30: 973-980.

Elliott, D.T. and Kaufmann, R.S. 2007. Spatial and Temporal Variability of Mesozooplankton and Tintinnid Ciliates in a Seasonally Hypersaline Estuary. Estuaries and Coasts 30: 418-430.

Ensminger, M.P., Budd, R., Kelley, K.C. and Goh, K. 2013. Pesticide occurrence and aquatic benchmark exceedances in urban surface waters and sediments in three urban areas of California, USA, 2008-2011. Environmental Monitoring and Assessment 185: 3697-3710.

Fonseca, V.F., Frana, S., Serafim, A., Company, R., Lopes, B., Bebianno, M.J., Cabral, H.N. 2011. Multi-biomarker responses to estuarine habitat contamination in three fish species: Dicentrarchus labrax, Solea senegalensis and Pomatoschistus microps.

Greenstein, D., Bay, S., Jacobe, M., Barton, C., Sakamoto, K., Young, D., Ritter, K. and Schiff, K. 2013. Regional assessment of marine and estuarine sediment toxicity in Southern California, USA. Environmental Monitoring and Assessment 185: 2055-2065.

Gunasekara, A.S. and Troung, T. 2007. Environmental fate of fipronil. California Environmental Protection Agency 1-28. 
Kaufmann, R.S., B.C. Stransky, D.T. Elliott, E. Kraak, D. Twal and K. Watters. 2006. Mission Bay Citizen Water Quality Monitoring and Education Program, Final Report. California State Water Resources Control Board, 12 pp.

Kayhanian, M., Stransky, C., Bay S., Laud, S. L. and Stenstromd, M.K. 2008. Toxicity of urban highway runoff with respect to storm duration. Science of the Total Environment 389: 386-406.

Lao, W., Tiefenthaler, L., Greenstein, D.J., Maruya, K.A., Bay, S.M., Ritter, K. and Schiff, K. 2012. Pyrethroids in southern California coastal sediments. Environmental Toxicology and Chemistry 31: 1649-1656.

Lao, W., Tsukada, D., Greenstein, D.J., Bay, S.M. and Maruya, K.A. 2010. Analysis, occurrence, and toxic potential of pyrethroids and fipronil in sediments from an urban estuary. Environmental Toxicology and Chemistry 29: 843-851.

Largier, J.L., Hollibaugh, J.T. and Smith, S.V. 1997. Seasonally hypersaline estuaries in mediterranean-climate regions. Estuarine, Coastal and Shelf Science 45: 789-797.

Lee, H., Lau, S., Kayhanian, M. and Stenstrom, M.K. 2004. Seasonal first flush phenomenon of urban stormwater discharges. Water Research 38: 4153-4163.

Li, Y., Lau, S., Kayhanian, M. and Stenstrom, M.K. 2005. Particle size distribution in highway runoff. Journal of Environmental Engineering 131: 1267-1276.

Pule, B.O., Mmualefe, L.C. and Torto, N. 2012. Analysis of polycyclic aromatic hydrocarbons in soil with agilent bond elut HPLC-FLD. Agilent Technologies, Inc. 8 pages.

Schiff, K., Diehl, D. and Valkirs, A. 2004. Copper emissions from antifouling paint on recreational vessels. Marine Pollution Bulletin 48: 371-377.

Schiff, K., Gossett, R., Ritter, K., Tiefenthaler, L., Dodder, N., Lao, W. and Maruya K. 2011. Southern California Bight 2008 Regional Monitoring Program: III. Sediment Chemistry. Southern California Coastal Water Research Project, Costa Mesa, CA.

Schlenk, D., Lavado, R., Loyo-Rosales, J.E., Jones, W., Maryoung, L., Riar, N., Werner, I. and Sedlak, D. 2012. Reconstitution studies of pesticides and surfactants exploring the cause of estrogenic activity observed in surface waters of the San Francisco Bay delta. Environmental Science and Technology 46: 9106-9111.

Seruto, C., Sapozhinikova, Y. and Schlenk, D. 2005. Evaluation of the relationships between biochemical endpoints of PAH exposure and physiological endpoints of reproduction in male California Halibut (Paralichthys californicus) exposed to sediments from a natural oil seep. Marine Environmental Research 60: 454-465.

Stransky, C. 1999. Assessment of sediment quality effects in Mission Bay and San Diego Bay on the growth, behavior and survival of California halibut (Paralichthys californicus). SDSU Masters Thesis.

Turner, A. 2010. Marine pollution from antifouling paint particles. Marine Pollution Bulletin 60: 159-171.

Velisek, J., Svobodova, Z. and Piackova, V. 2009. Effects of acute exposure to bifenthrin on some haematological, biochemical and histopathological parameters of rainbow trout (Oncorhynchus mykiss). Veterinarni Medicina 3: 131-137. 
Weston, D.P., Holmes, R.W., You, J. and Lydy, M.J. 2005. Aquatic toxicity due to residential use of pyrethroid insecticides. Environmental Science and Technology 39: 9778-9784.

Weston, D.P., Holmes, R.W. and Lydy, M.J. 2009. Residential runoff as a source of pyrethroid pesticides to urban creeks. Environmental Pollution 157: 287-294.

Weston, D.P. and Lydy, M.J. 2012. Stormwater input of pyrethroid insecticides to an urban river. Environmental Toxicology and Chemistry 31: 1579-1586.

Yoon, V.K. and Stein, E.D. 2008. Natural catchments as sources of background levels of stormwater metals, nutrients, and solids. Journal of Environmental Engineering 134: 961973. 
Chapter 3.0 - Morphometric and Biomarker Characteristics of Juvenile California Halibut (Paralichthys californicus) in Mission Bay, San Diego, California

\section{1 - Introduction}

Fish are important indicators of the health of marine ecosystems. Especially in soft bottom and estuarine habitats, demersal fishes are key members of the food web and are valuable to commercial and recreational fisheries. These fishes are also most vulnerable to chronic exposure to inorganic and organic contaminants that are present in these habitats due to their direct contact with contaminated sediment and their tendency to feed on benthic infauna (Brown and Steinert 2003). Aquatic environments rarely are affected by just one class of contaminants and often exhibit a "cocktail" of contaminants, some of which are commonly monitored, such as metals, aromatic hydrocarbons, pesticides and endocrine disrupting chemicals. There are those that are less often targeted, including pharmaceuticals, flame retardants, microplastics and nanoparticles (Celander 2011). There is a need to expand our understanding of these contaminants past just characterizing their presence in the environment, focusing more on how biological communities are affected by their presence (van der Oost et al. 2003, Fonseca et al. 2011a). While demersal fishes are often monitored in terms of ecologically valuable metrics such as population and assemblage patterns, these are affected by environmental variables as well and do not necessarily reflect exposure to contaminants (Brown and Steinert 2003).

Bioaccumulation studies are useful to track how these compounds move through food webs, but in general they are very species-specific and show complications regarding toxicokinetics, metabolism, and organ-specific bioaccumulation when attempting to compare across taxa (van der Oost et al. 2003, Eggleton and Thomas 2004). Also, bioaccumulation studies fail to show biological significance much in the same way as those that rely only on sediment contaminant concentrations. A better approach is to use bioaccumulation models as well as biomarkers in fishes to assess their exposure to contaminated habitats 
(van der Oost et al. 2003). Biomarkers are indicators of biological response that are dependent on the magnitude and duration of exposure (van der Oost et al. 2003). Even at sub-lethal concentrations, biomarkers in fish have been shown to be sensitive and reliable indicators for exposure to a variety of contaminants (Whyte et al. 2000, Martnez -'lvarez et al. 2005 ).

Field studies using biomarkers are most effective when multiple biomarkers are used due to complex contaminant exposures and species-specific responses to environmental stress (SolØ et al. 2009, Kopecka-Pilarczyk 2013). Mixtures of organic and inorganic contaminants can have cocktail effects that can mask correlations if only one biomarker is considered (Celander 2011, Fonseca et al. 2011a). Mission Bay has been shown to have both metals and pesticides present in sediments (Stransky 1999, Kaufmann et al. 2006, Lao et al. 2012), thus a multiple biomarker approach was employed in this study. Morphometric indices such as condition factor K and hepatosomatic index (HSI) were used for measuring the general condition of the fish and for determining growth potential and energy storage (Amara et al. 2007, Fang et al. 2010, Fonseca et al. 2011a). Cellular biomarkers were used to target more specific effects that precede higher biological disruption. The first of these is EROD activity, which is a catalytic measurement of cytochrome P4501A monooxygenase, a major enzyme responsible for reactions in tissues that transform xenobiotics into more easily eliminated forms (Whyte et al. 2000). It is present in multiple tissues in fish and is induced following exposure to planar aromatic hydrocarbons such as PAHs, coplanar PCBs, and some PBDEs (Whyte et al. 2000, SolØ et al. 2009, Fonseca et al. 2011a, Lu et al. 2013). EROD may be influenced by some abiotic variables, such as salinity and temperature (Kopecka-Pilarczyk 2013), and shows high interspecific variation (Fonseca et al. 2011a, b). Exposure to EROD-inducing chemicals can be a precursor as well as an indicator of other health impairments such as tissue damage, tissue lesions, immune system suppression, metabolism alteration, and carcinogen exposure, in some cases due to the metabolism of parent compounds that have reactive metabolites (Whyte et al. 2000). The other cellular biomarker used was lipid peroxidation, which is measured using a 
thiobarbituric acid reactive substance (TBARS) assay. Lipid peroxidation, or the oxidation of polyunsaturated fatty acids, can occur due to exposure to chemicals with high reduction-oxidation capacities or by deficiencies in antioxidants and detoxifying mechanisms potentially leading to cellular damage (Ferriera et al. 2005). Factors intrinsic to the fish itself (age, feeding behavior, trophic level) environmental factors (temperature, salinity, dissolved oxygen) and contaminant exposure (metals, PAHs, pesticides) all can alter antioxidant defense and oxidative damage (Martnez - 'lvar ez et al. 2005). Therefore, lipid peroxidation is considered a non-specific biomarker that can be an indicator of cellular damage.

Tissues selected for EROD and TBARS analysis were liver, kidney and gill. The liver is an intuitive choice for its primary role in detoxification, excretion and metabolism (Costa et al. 2009, Pereira et al 2010a). Kidneys also play a major role in the metabolism and excretion of xenobiotics and have hematopoietic, endocrine and immune functions, giving this organ high potential as a candidate for biomarker analysis (Pereira et al. 2010a). The gills are another prime candidate due to their exposure to the aquatic environment, their role in excretion of electrolytes, and the fact that they receive almost all of the cardiac output of the fish before that blood is circulated to other tissues (Costa et al. 2009, Pereira et al. 2010b). One objective of this investigation was to determine the tissues that best reflected environmental conditions where the fish were captured.

California halibut (Paralichthys californicus) is a commercially and recreationally important flatfish found from Washington State to Almejas Bay, Baja California Mexico. In 2011, the total landings of Califonia halibut were 199.7 tons valued at $\$ 2.17$ million dollars (CA DFG 2011). The Southern California fishery is estimated to be at $14 \%$ of historic levels, but is thought to be sustainable at the current rate (CA DFG 2011). More attention needs to be focused on the population dynamics of these fish to ensure a healthy fishery for the future. The adults tend to live offshore in sandy habitats near rocky reefs, but the juveniles use predominantly bay and estuarine habitats as nursery areas during their first year of life due to benefits such as abundance of food, fewer predators and increased growth rates in the warmer water (Stransky 1999, Lpez -Rasgado 
and Herzka 2009). Younger juveniles are thought to use shallow habitats near eelgrass beds and move into deeper habitats as they age (Fodrie and Mendoza 2006, Fodrie and Herzka 2008). California halibut remain in these nursery habitats for about one year before migrating to deeper waters (Forrester and Swearer 2002). Otolith microchemistry has suggested that adults that migrate out of bays tend to stay close to their nursery habitat, usually within $10 \mathrm{~km}$ (Forrester and Swearer 2002, Fodrie and Herzka 2013). This life history stage also makes them susceptible to anthropogenic impacts in the form of polluted sediments in embayments. San Diego has two large bays, San Diego Bay and Mission Bay, both of which serve as important nursery areas for juvenile halibut (Stransky 1999, Forrester and Swearer 2002) and as habitat for older halibut in San Diego County (Kramer 1991, Fodrie and Levin 2008). Previous studies have used halibut as test species for testing bile FACs (Brown and Steinert 2003, Seruto et al. 2005), CYP1A activity (Seruto et al. 2005), DNA damage (Brown and Steinert 2003), estrogenic activity (Schlenk et al. 2005) and tissue damage/mortality (Stransky 1999). These studies for the most part have been carried out in the lab, but previous work with Senegalese sole that compared field and lab exposures to the same sediments found that different responses can be produced by lab vs. in situ exposures (Costa et al. 2011). In that study, the field exposures showed more tissue abnormalities relative to a reference site and lab exposed fish had slightly different presentation of liver histopathologies. The only biomarker that showed good correlation to field/lab conditions was bile FACs (Brown and Steinert 2003, Seruto et al. 2005), while other biomarkers were limited by low N values (Brown and Steinert 2003) or by not correlating well to the contaminant concentrations of interest (Stransky et al. 1999, Schlenk et al. 2005).

The purpose of this study was to examine variation in morphological and cellular biomarkers in juvenile California halibut across a contamination gradient in Mission Bay across seasons to evaluate sublethal environmental stress. The study area was Mission Bay, San Diego, California, which has been shown to have a natural gradient of sediment properties and contamination concentrations extending from the mouth of the bay to the inner reaches of the bay where urban 
watersheds drain via three creeks and numerous storm drains (Stransky 1999, Kaufmann et al. 2006).

\section{2 - Methods}

\subsection{1 - Site description}

Halibut were collected at six sites in Mission Bay (Fig. 3.1) over the course of one annual cycle (June 2012 through May 2013). Two sites were sampled in the front bay near the mouth of the bay (Mariner's Cove, Ventura Cove), two in the mid-bay (Fiesta Bay, Crown Point), and two in the back bay (near the mouths of Cudahy Creek and Tecolote Creek). At all sites, halibut were collected off the beach using a seine net. At some sites (see below), halibut also were collected with an otter trawl. Descriptions of both types of sampling gear and included below (section 3.2.2).

\section{Mariner's Cove}

The closest site to the entrance of the bay, this cove is directly across from Quivira Basin and is formed by the arm of Mission Point Park (Fig. 3.1). The eelgrass bed is in the south and northeast portions of the cove and extends from the shore at low tide out into the opening of the cove, which has a maximum depth of $c a .6 \mathrm{~m}$. Halibut were collected by seining near the southern arm of the cove, while otter trawl samples were taken around the two headlands that make up the entrance to the cove.

\section{Ventura Cove}

This site is located directly to the northwest of the West Mission Bay Drive bridge, across from Vacation Island (Fig. 3.1). This beach has a steep slope with eelgrass beds forming a border along the beach, while the channel off the beach has a maximum depth of $c a .5 \mathrm{~m}$. Halibut were collected off the beach at this site.

\section{Fiesta Bay}

This site is located on the northwest side of Fiesta Island, on the beach that is due east of the beacon island in the middle of Fiesta Bay (Fig. 3.1). The eelgrass beds 
extend the length of the beach, and at times are exposed by the low tide. Halibut were collected off the beach at this site.

\section{Crown Point}

This site is located on the northeast side of Crown Point, directly south of the boundary for the Kendall-Frost/Northern Wildlife Reserves (Fig. 3.1). The eelgrass is close to shore near the reserve boundary and extends farther out near the sandy swim area. Halibut were collected off the beach, while the otter trawl was used in the deeper channel due east of the beach.

\section{Cudahy Creek}

Cudahy Creek is located to the east of the northeast side of Fiesta Island (Fig. 3.1). The site has eelgrass beds off the Fiesta Island side and between the rocky point extending all the way to the creek mouth to the southeast. Halibut were collected off the beach on both the Fiesta Island and mainland portions of the beach. Trawl samples were collected in the area between Fiesta Island and the creek outlet.

\section{$\underline{\text { Tecolote Creek }}$}

Tecolote Creek is located just to the north of the causeway that provides access to Fiesta Island (Fig. 3.1). The eelgrass beds are all along the shore in the basin, and the slope of the beach is moderate, with evidence of stingray feeding pits commonly observed on the shore during a low tide. Halibut were collected off the beach near the basin, while the otter trawl was deployed in the channel farther north due to access restrictions in the basin area itself.

\subsection{2 - Field sampling}

Field collections were conducted from June 2012 through May 2013 at all six sites in Mission Bay. Halibut were collected using a seine net (30.5 m long, 1 $\mathrm{m}$ tall, $1 \mathrm{~cm}$ mesh, $0.5 \mathrm{~cm}$ bag mesh) and an otter trawl (doors $30 \times 60 \mathrm{~cm}, 2.5 \mathrm{~cm}$ mesh, $1 \mathrm{~cm}$ cod end mesh). The seine was deployed off the beach, while the otter trawl was deployed from a university research vessels. Once caught, halibut were put into coolers filled with water from the site of collection and transported back 
to the lab. "Juvenile" halibut in this study includes fish from $1.83-35.80 \mathrm{~cm} \mathrm{SL}$, but no halibut that had mature gonads were included in the analysis. This distinction was made in part due to the distribution of halibut in the bay, as well as the confounding nature of seasonal spawning on biomarker interpretation (Whyte et al. 2000, Martnez -'lvarez et al. 2005 ).

\subsection{3 - Lab processing}

Fish were brought back to the lab and placed in filtered seawater tanks until they could be processed. First, the halibut was anesthetized using MS-222 at $75 \mathrm{mg} / \mathrm{L}$ for 10 minutes. Once anesthetized, the fish was measured for standard length and total body weight, and general condition was assessed. The fish was then decapitated using a scalpel according to an IACUC-approved method. The liver, kidney, gills, gall bladder and a muscle sample were then dissected out, weighed, and stored on dry ice until long-term storage in a $-80^{\circ} \mathrm{C}$ freezer. Halibut that were found to be sexually mature were excluded from analysis.

\subsection{4 - Tissue Preparation}

Preparations were performed according to the method by Lavado et al. (2004) with minor modifications. Livers, kidneys and gills were homogenized in homogenization buffer $(1: 5 \mathrm{w} / \mathrm{v}, 100 \mathrm{mM}$ phosphate buffer $\mathrm{pH} 7.4+100 \mathrm{mM} \mathrm{KCl}$ $+1 \mathrm{mM}$ EDTA) using glass mortar and ceramic pestle. The homogenate was then centrifuged for 20 minutes at $12,000 \mathrm{~g}$ and $4^{\circ} \mathrm{C}$, and the supernatant containing the microsomes and cytosol was collected. The supernatant was then ultracentrifuged for 60 minutes at $100,000 \mathrm{~g}$ and $4^{\circ} \mathrm{C}$. The cytosolic fraction was removed, and the microsomal fraction was resuspended in microsomal buffer (1:5 w/v, $100 \mathrm{mM}$ phosphate buffer pH $7.4+100 \mathrm{mM} \mathrm{KCl}+1 \mathrm{mM}$ EDTA $+20 \%$ glycerol). These fractions were stored at $-80^{\circ} \mathrm{C}$ until used for biomarker assays.

\subsection{5 - Biomarker assays}

Morphometric biomarkers were calculated using the formulas (van der Oost 2003):

$$
\mathrm{K}=\left(\mathrm{W}_{\mathrm{B}} / \mathrm{L}^{3}\right)^{*} 100
$$




$$
\mathrm{HSI}=\left(\mathrm{W}_{\mathrm{L}} / \mathrm{W}_{\mathrm{B}}\right)^{*} 100
$$

Where $\mathrm{W}_{\mathrm{B}}=$ body weight $(\mathrm{g}), \mathrm{W}_{\mathrm{L}}=$ liver weight $(\mathrm{g}), \mathrm{L}=$ standard length $(\mathrm{cm})$, $\mathrm{K}=$ condition factor and $\mathrm{HSI}=$ hepatosomatic index.

Microsomal and cytosolic fractions were normalized for protein content using the Bradford method (Bradford 1976). Concentrations of $0.1 \mathrm{mg}$ protein $/ \mathrm{mL}$ were used for the biomarker assays. Samples that did not have high enough concentrations of protein were excluded from further analysis.

EROD assays were performed according to the method by Lavado et al. (2006) with modifications for plate reading. Microsomes were used for EROD assays. The samples were added to $50 \mu \mathrm{m}$ 7-Ethoxyresorufin and $5 \mathrm{mM} \mathrm{NADPH}$ and incubated at $25^{\circ} \mathrm{C}$ for 10 minutes. Cold methanol was added to stop the reaction, and then the samples were centrifuged for 10 minutes at 13,000 rpm and room temperature to precipitate proteins. The supernatant was collected and analyzed using a PerkinElmer Victor2 set for fluorescence at 530/605 nm using resorufin as a standard. Samples and resorufin standards were run in duplicates and the average fluorescence was used.

TBARS assays were performed according to the method by Jentzsch et al. (1996) with minor modifications for plate reading. Cytosol was used for TBARS assays. The samples were added to $200 \mathrm{mM}$ phospohoric acid, $12.6 \mathrm{mM}$ butylated hydroxy toluene, and $110 \mathrm{mM}$ thiobarbituric acid then incubated at $90^{\circ}$ $\mathrm{C}$ for 45 minutes. The samples were put in ice to stop the reaction and n-butanol and saturated $\mathrm{NaCl}$ solution was added and centrifuged for 2 minutes at 13,000 rpm and room temperature. The supernatant was collected and analyzed using a PerkinElmer Victor2 set for fluorescence at 530/605nm using malondialdehyde as a standard. Samples and malondialdehyde standards were run in duplicates and the average fluorescence was used.

\subsection{6 - Statistical Analysis}

Biomarkers were broken down into different groups and analyzed with environmental data as well as sediment chemistry data, both with and without pesticides. The datasets with and without pesticides were separate because the 
dataset without pesticides is from all four seasons, versus the dataset with pesticides is only from Spring 2013. The biomarker groupings were as follows:

\begin{tabular}{|l|l|}
\hline \multicolumn{1}{|c|}{ Group } & \multicolumn{1}{c|}{ Biomarkers Included } \\
\hline All Biomarkers & $\begin{array}{l}\text { Hepatic-Somatic Index (HSI), Condition Factor K, Liver } \\
\text { EROD, Liver TBARS, Kidney EROD, Kidney TBARS, Gill } \\
\text { EROD, Gill TBARS }\end{array}$ \\
\hline Morphometric Biomarkers & Hepatic-Somatic Index (HSI), Condition Factor K \\
\hline Cellular Biomarkers & $\begin{array}{l}\text { Liver EROD, Liver TBARS, Kidney EROD, Kidney TBARS, } \\
\text { Gill EROD, Gill TBARS }\end{array}$ \\
\hline EROD & Liver EROD, Kidney EROD, Gill EROD \\
\hline TBARS & Liver TBARS, Kidney TBARS, Gill TBARS \\
\hline Liver & Liver EROD, Liver TBARS \\
\hline Kidney & Kidney EROD, Kidney TBARS \\
\hline Gill & Gill EROD, Gill TBARS \\
\hline Liver EROD & Liver EROD \\
\hline Liver TBARS & Liver TBARS \\
\hline Kidney EROD & Kidney EROD \\
\hline Kidney TBARS & Kidney TBARS \\
\hline Gill EROD & Gill EROD \\
\hline Gill TBARS & Gill TBARS \\
\hline & \\
\hline
\end{tabular}

The groupings of environmental data and sediment chemistry was as follows:

\begin{tabular}{|l|l|}
\hline Group & Environmental/Sediment Chemistry Included \\
\hline Environmental & Median Grain Size, Temperature, Salinity \\
\hline Sediment Chemistry & Total PAHs, Cu, Zn \\
\hline $\begin{array}{l}\text { Sediment Chemistry with } \\
\text { Pesticides }\end{array}$ & $\begin{array}{l}\text { Total PAHs, Cu, Zn, Total Pyrethroids, Total Fipronils, Total } \\
\text { PBDEs }\end{array}$ \\
\hline
\end{tabular}

All morphometric data, biomarker data, environmental variables, sediment characteristics and sediment chemistry were analyzed for significant correlations using the statistics program R. Variables were compared to each other using a two-tailed Pearson product-moment correlation test.

Multivariate statistical analysis for biomarkers was run with PRIMER-E software. 
The first test used was principal coordinates analysis (PCO). PCO is an ordination operation based on a resemblance matrix that is calculated using Euclidean distances. Unlike non-metric multidimensional scaling (MDS) which uses only rank-orders to create an ordination, PCO uses the actual dissimilarity of samples to create the ordination. The goal of the ordination is to reduce the dimensionality of the data cloud to allow the most salient patterns and structures to be observed. PCO also gives a closer reflection of the resemblance values actually used in partitioning methods like PERMANOVA. By overlaying vectors that are calculated by correlation with environmental variables, patterns in how the ordination corresponds to matching environmental data can been seen.

The second test used was PERMANOVA. This is a routine for testing simultaneous responses of one or more variables to one or more factors in an analysis of variance experimental design on the basis of any resemblance measure, using permutation methods. It was used to separate out significant differences amongst sites and seasons for the biomarker datasets. Once significance was determined for sites or seasons, pairwise comparison was performed to try to establish groups of sites/seasons that were most similar to one another.

The third test was canonical analysis of principal coordinates (CAP). The purpose of CAP is to find axes through the multivariate cloud of points that either a) discriminate best among a priori groups or b) have the strongest correlation with some other set of variables. In some cases, there are known differences among pre-defined groups (e.g., from significant result of PERMANOVA analysis), and the goal is to characterize those differences. CAP uses the central question: is there an axis through the multivariate cloud of points that is best at separating groups? This axis can be fundamentally different from the direction of greatest total variation across the data cloud, which sometimes makes these groups hard to see on PCA, MDS or PCO plots. The results of the model are cross-validated by removing one sample at a time and checking the ability of the model to correctly classify the sample into its appropriate group. This procedure gives specific information about how distinct the groups are and how well the 
PCO axes discriminate among the groups, and is the best way to test the validity and utility of the CAP model.

To test the biomarker datasets against their respective environmental conditions and sediment chemistry, the tests RELATE and BEST were used. RELATE is a routine that identifies among-sample relationships between two resemblance matrices of environmental and biotic data that use the same sample IDs (are a matching set of samples). Once significance was established with RELATE, BEST was run. BEST is a non-parametric procedure that finds the 'best' match between the multivariate among-sample patterns of an assemblage and those from environmental variables associated with those samples. This procedure ranks and determines correlation values (expressed as $\rho$ ), and is capable of identifying combinations of environmental/sediment chemistry variables that best correlate with the morphometric and biomarker datasets.

\section{3 - Results}

\subsection{1 - Spatial Variation}

Halibut caught in Mission Bay varied significantly in size between sites (Table 3.1, Fig. 3.2). Mann-Whitney $U$ analysis showed that the largest individuals across the entire sampling period were collected at Tecolote Creek $($ mean $\pm \mathrm{sd}=20.11 \pm 6.54 \mathrm{~cm})$, while the smallest individuals $(8.62 \pm 4.60 \mathrm{~cm})$ came from Fiesta Bay. This was a consistent pattern across seasons. The largest fish caught during the study $(32.70 \mathrm{~cm})$ came from Cudahy Creek. Halibut from Fiesta Bay had the lowest mean standard length $(8.62 \pm 4.60 \mathrm{~cm})$. Fish from Ventura Cove and Crown Point had similar mean standard lengths $(10.40 \pm 5.80$ $\mathrm{cm}$ and $10.84 \pm 6.17 \mathrm{~cm}$, respectively), while those from Mariners Cove were slightly higher $(11.81 \pm 5.83 \mathrm{~cm})$. The largest single fish was from Crown Point $(35.80 \mathrm{~cm})$, while the smallest fish was from Fiesta Bay $(1.83 \mathrm{~cm})$.

Condition factor, $\mathrm{K}$, was not statistically different among sites in Mission Bay (Table 3.1, Fig. 3.4). Halibut from Mariners Cove had the highest mean $\mathrm{K}$ $(1.54 \pm 0.22)$, while fish from Crown Point and Cudahy Creek had the lowest mean K score $(1.45 \pm 0.11)$. 
The hepatosomatic index (HSI) score for halibut was found to be statistically different between sites in Mission Bay (Table 3.1, Fig. 3.3). Fish from Tecolote Creek and Cudahy Creek had significantly lower mean HSI scores $(0.82 \pm 0.36$ and $0.80 \pm 0.23$, respectively) than fish from the other sites. Fish from Mariners Cove had the highest mean HSI score $(1.09 \pm 0.51)$, and those from Ventura Cove, Fiesta Bay and Crown Point had similar mean scores (0.98 \pm $0.28,0.99 \pm 0.31$ and $1.00 \pm 0.33$, respectively). The lowest score for Tecolote Creek came in Fall of 2012.

Biomarkers were analyzed with PERMANOVA for significance between sites and the combination of sites and seasons. When significance was found, pairwise comparison was done to determine which groups were different from each other. CAP modeling was used to determine which sites were most distinct from one another.

Analysis of EROD in the three tissues found that kidney and gill differed significantly between sites, while liver did not (Table 3.2). Gill also differed significantly for the combination of site and season. For all three tissues, halibut from Mariners Cove had the highest mean values (liver: $458.9 \pm 264.9$, kidney: $423.9 \pm 122.9$, gill: $457.5 \pm 269.4$ pmol resorufin $\min ^{-1} \mathrm{mg}_{\text {protein }}{ }^{-1}$; Table 3.1) Liver and gill had their lowest mean values at Cudahy Creek (liver: $396.4 \pm 99.8$, gill: $239.5 \pm 36.5$ pmol resorufin $\min ^{-1} \mathrm{mg}$ protein ${ }^{-1}$ ), while kidney had its lowest mean value at Fiesta Bay $\left(266.6 \pm 26.4\right.$ pmol resorufin min $^{-1} \mathrm{mg}_{\text {protein }}{ }^{-1}$; Table 3.1). For kidney, pairwise comparisons of sites did not yield exclusive groups, as it created four groups with three to five sites per group. The CAP model showed that Mariners Cove (58\% correct) and Fiesta Bay (56\% correct) were the most distinctive, while Crown Point (6\% correct) and Cudahy Creek (8\% correct) were the least distinctive (Table 3.3). For gill, pairwise comparison of sites did not yield exclusive groups, as there were four groups with three to four sites per group. The CAP model showed that CC (56\% correct), MC (55\% correct) and CP (50\% correct) were the most distinctive, while VC $(0 \%$ correct) was the least distinctive (Table 3.3). 
Analysis of TBARS in the three tissues found that liver and gill differed significantly between sites, while kidney did not (Table 3.2). The highest mean values were from Tecolote Creek (liver: $1.00 \pm 0.75$, kidney: $0.40 \pm 0.27 \mu \mathrm{mol}$ MDA g tissue ${ }^{-1}$ ) and Mariners Cove (liver: $0.97 \pm 0.78$, gill: $0.38 \pm 0.27 \mu \mathrm{mol}$ MDA $g$ tissue $^{-1}$; Table 3.1). The lowest mean value for liver was from Ventura Cove $\left(0.47 \pm 0.50 \mu \mathrm{mol}\right.$ MDA $g$ tissue $\left.^{-1}\right)$, while kidney and gill had their lowest mean values at Fiesta Bay (kidney: $0.16 \pm 0.11$, gill: $0.12 \pm 0.07 \mu \mathrm{mol}$ MDA g tissue $^{-1}$ ) and Crown Point (gill: $0.12 \pm 0.07 \mu$ mol MDA g tissue ${ }^{-1}$; Table 3.1). For liver, pairwise comparison of sites did not create exclusive groups, as Mariners Cove/Tecolote Creek separated out but the other three groups had between four and five sites. The CAP model showed that VC (49\% correct) was the best, while TC $(0 \%$ correct $)$ and $\mathrm{MC}(0 \%$ correct) were the least distinctive (Table 3.3). CP (3\% correct), FB (4\% correct) and CC (6\% correct) also did not score well and likely contributed to the indistinct groupings. For gill, pairwise comparison of sites did not yield exclusive groups, as there were four groups with 3-5 sites in each. The CAP model showed that MC (64\% correct) and FB (53\% correct) were the most distinct, while CP (0\% correct) was the least distinct (Table 3.3).

The combined dataset for all biomarkers showed a significant difference between sites (Table 3.2). The PCO plot did not show many distinct groupings, although Mariners Cove was restricted to the middle of the plot and Fiesta Bay was only on the right side of the plot (Fig. 3.5). Pairwise comparison of sites created six groups with three to five sites in each. The CAP model determined that Fiesta Bay (50\% correct) and Crown Point (40\% correct) were the most distinct sites, while Mariners Cove, Tecolote Creek and Ventura Cove (29\%, 33\% and $33 \%$ correct, respectively) were the least distinctive (Table 3.3).

The combined dataset for morphometric biomarkers showed a significant difference between sites (Table 3.2). The PCO for the morphometric biomarker dataset is very congested (Fig. 3.6), as it has the most data points out of any of the other datasets, so inferences as to groupings are better through PERMANOVA and the CAP model. Pairwise comparison of sites revealed 5 groups. One group was Tecolote Creek, another was Cudahy Creek, and a third was Fiesta 
Bay/Mariners Cove. The other two groups were larger, one consisting of Crown Point/Ventura Cove/Mariners Cove, the other consisting of Crown Point/Fiesta Bay/Ventura Cove/Mariners Cove. For this dataset, the back bay separated out from the front/middle bay sites. The CAP model revealed that Tecolote Creek (69\% correct) was the most distinct with Fiesta Bay (57\% correct) next (Table 3.3). The least distinctive sites were Ventura Cove (2\% correct), Crown Point (10\% correct) and Mariners Cove (13\% correct), which can explain some of the groupings from PERMANOVA.

The combined dataset for cellular biomarkers showed a significant difference between sites (Table 3.2). The PCO plot shows some distinct groupings such as Mariners Cove and Fiesta Bay, while the other sites are more spread out (Fig. 3.7). Pairwise comparison of sites did not create exclusive groups. The CAP model showed that FB (70\% correct) was the most distinct with MC (57\% correct) second (Table 3.3). VC ( $0 \%$ correct) and TC (13\% correct) were the least distinctive groups according to the model.

The combined dataset for EROD showed a significant difference between sites (Table. 3.2). The PCO for EROD showed that sites like Fiesta Bay and Mariners Cove had tight nuclei, although each had an outlier (Fig. 3.8). Pairwise comparison of sites created six groups with three to six sites in each. The CAP model determined that Fiesta Bay and Mariners Cove were the most distinct (80\% and $71 \%$ correct identification), while Tecolote Creek and Ventura Cove (7\% and $8 \%$ correct, respectively) were the least distinguishable from other sites (Table $3.3)$.

The combined dataset for TBARS showed a significant difference between sites (Table 3.2). The PCO for TBARS showed a large spread with no tight nucleus like EROD, and groupings were hard to distinguish, although some sites separated themselves loosely from one another, e.g., Mariners Cove (Fig. 3.9). Pairwise analysis of sites created three groups, one with Mariners Cove/Tecolote Creek/Ventura Cove and the other two groups with five sites each and essentially no distinctiveness among groups. The CAP model showed that Fiesta Bay was the most distinct group (70\% correct) with Mariners Cove second 
(57\% correct; Table 3.3$)$. Cudahy Creek (15\% correct) and Ventura Cove (17\% correct) were the least distinct groups.

The combined dataset for liver biomarkers showed no significant difference between sites (Table 3.2). However, the p-value was only slightly higher (0.054) than the predetermined level for significance (0.05), so interpretation was still made as if the test indicated significance. The PCO graph was hard to interpret with a nucleus of several sites in the middle of the graph and numerous points to the right (Fig. 3.10). Mariners Cove can be seen bunched in the middle, but there are also several outliers. Pairwise comparison of sites did not yield exclusive groupings as it created five groups with three to six sites per group. The CAP model showed that Mariners Cove (56\% correct) and Ventura Cove ( $46 \%$ correct) were the most distinctive, while Fiesta Bay (0\% correct) and Crown Point (3\% correct) were the least distinctive (Table 3.3).

The combined dataset for kidney biomarkers showed a significant difference between sites (Table 3.2). The PCO for kidney biomarkers had very little spread, so groups were determined with other statistical tools (Fig. 3.11). Pairwise comparison of sites did not create exclusive groups as it created five groups with three to six sites per group. The CAP model shows that Mariners Cove (67\% correct) and Fiesta Bay (56\% correct) are the most distinctive sites, while Cudahy Creek (4\% correct) and Crown Point (6\% correct) are the least distinct (Table 3.3). Tecolote Creek (13\% correct) and Ventura Cove (16\% correct) also scored poorly, which helps explain the poor separation on the PCO graph and in the PERMANOVA results.

The combined dataset for gill biomarkers showed a significant difference between sites (Table 3.2). The PCO graph showed a tight cluster for Fiesta Bay, while Mariners Cove and Ventura Cove separated themselves loosely to the left of the dense nucleus (Fig. 3.12). Pairwise analysis of sites created two groups, one with Mariners Cove/Ventura Cove/Tecolote Creek, while the other had Fiesta Bay/Crown Point/Cudahy Creek. The CAP model showed that MC (64\% correct) and FB (53\% correct) were the most distinct, while CP ( $0 \%$ correct) was the least distinct (Table 3.3). 


\subsection{2 - Temporal Variation}

Halibut caught in Mission Bay did not vary significantly in standard length between seasons (Table 3.4, Fig. 3.2). Smaller halibut were caught in the summer $(10.14 \pm 6.03 \mathrm{~cm})$, while generally larger fish were collected in the spring (12.03 $\pm 5.98 \mathrm{~cm}$; Fig. 3.13$)$.

Condition factor, K, was not significantly different between seasons (Fig. 3.4, Table 3.4). The highest mean value was for halibut collected in winter (1.53 $\pm 0.20)$, while the lowest mean value was for fish collected in summer (1.43 \pm 0.10 ; Table 3.4).

The hepatosomatic index for halibut caught in Mission Bay differed significantly between seasons (Fig. 3.3). Mann-Whitney $\mathrm{U}$ analysis determined that summer/spring were a group, summer/winter/spring were a group, and fall/winter were a group (Fig. 3.3). The highest mean values were for fish collected in the fall $(1.03 \pm 0.31)$ and winter $(1.02 \pm 0.35)$, while the lowest mean value was for fish collected in the spring $(0.87 \pm 0.28$; Table 3.4).

Biomarkers were analyzed with PERMANOVA for significance between seasons and the combination of sites and seasons. When significance was found, pairwise comparison was done to determine which groups were different from each other. CAP modeling was used to determine which sites were most distinct from one another.

Analysis of EROD for the three tissues found that liver and gill differed significantly between seasons, and gill differed significantly when site and season were combined (Table 3.2). Kidney did not differ significantly between seasons. The highest mean value for liver was in the spring $\left(555.0 \pm\right.$ pmol resorufin $\mathrm{min}^{-1}$ $\mathrm{mg}$ protein $^{-1}$ ), while the highest mean value for kidney and gill was in the fall (kidney: $343.9 \pm 129.3$, gill: $335.4 \pm 125.3$ pmol resorufin min $^{-1} \mathrm{mg}$ protein ${ }^{-1}$; Table 3.4). The lowest mean value for liver was in the summer (350.4 \pm 49.4 pmol resorufin min $^{-1} \mathrm{mg}$ protein ${ }^{-1}$ ), while the lowest mean value for kidney and gill was in the winter (kidney: $314.1 \pm 93.9$, gill: $276.5 \pm 78.5$ pmol resorufin min ${ }^{-}$

${ }^{1} \mathrm{mg}_{\text {protein }}{ }^{-1}$; Table 3.4). For liver, pairwise comparisons of seasons found that 
there were three groups, one with summer/fall, one with fall/winter and one with spring. The CAP model found that summer (66\% correct) and spring (63\% correct) were the most distinct, while fall (6\% correct) and winter (10\% correct) were the least distinct (Table 3.5). For gill, pairwise comparison of seasons created two groups, with one including summer/fall/spring and the other with fall/winter/spring. The CAP model showed that winter (69\% correct) and fall (54\% correct) were the most distinct while summer (0\% correct) and spring (6\% correct) were the least distinct (Table 3.5).

Analysis of TBARS for the three tissues found that liver differed between seasons, while kidney and gill did not have significant differences (Table 3.2). All three tissues had their highest mean value in the fall (liver: $0.99 \pm 0.67$, kidney: $0.43 \pm 0.62$, gill: $0.26 \pm 0.28 \mu \mathrm{mol} \mathrm{MDA} \mathrm{g} \mathrm{tissue}{ }^{-1}$; Table 3.4). Liver and gill had their lowest mean values in the spring (liver: $0.23 \pm 0.22$, gill: $0.15 \pm 0.11$ $\mu$ mol MDA g tissue ${ }^{-1}$ ), while the lowest mean value for kidney was observed in the winter $\left(0.24 \pm 0.21 \mu \mathrm{mol} \mathrm{MDA} \mathrm{g} \mathrm{tissue}{ }^{-1}\right.$; Table 3.4). For liver, pairwise comparison of seasons showed three groups: summer/fall, winter and spring. The CAP model showed that spring $(78 \%$ correct $)$ and fall $(68 \%$ correct $)$ were the most distinct, while summer (9\% correct) and winter (19\% correct) were the least distinct (Table 3.5).

The combined dataset for all biomarkers showed a significant difference between seasons (Table 3.2). The PCO for all biomarkers showed that summer and fall had similar distributions, while spring and winter were more widely distributed and variable (Fig. 3.14). Based on pairwise comparisons, spring was separate from the other three seasons. The CAP model was able to discern seasons well, with summer $(75 \%$ correct) being the most distinct and winter $(42 \%$ correct) the least distinct (Table 3.5).

The combined dataset for morphometric biomarkers was analyzed with PERMANOVA, which determined that there was a significant difference between seasons (Table 3.2). The PCO graph had a dense group of points with a few outliers (Fig. 3.15), so groups are easier to determine with other statistical analyses. Pairwise comparisons of the PERMANOVA data for season showed 
three groups; summer/spring, fall/winter and spring/fall. The CAP model shows that summer (62\% correct) and winter (47\% correct) were the most distinct, with fall (6\% correct) and spring (31\% correct) the least distinct (Table 3.5).

The combined dataset for cellular biomarkers showed a significant difference between seasons (Table 3.2). The PCO for cellular biomarkers showed some separation of seasons, such as summer, but distinct groups were hard to see (Fig. 3.16). Pairwise comparison of seasons showed that spring separated out from the other three seasons. The CAP model showed that summer (67\% correct) and spring $(56 \%$ correct) correct were the most distinct seasons (Table 3.5). Winter (24\% correct) and fall (36\% correct) were the least distinctive.

The combined dataset for EROD showed a significant difference between seasons (Table 3.2). The PCO graph for EROD showed a nucleus with all seasons and then an indistinct spread of points that includes all seasons (Fig. 3.17), so inferences were made with other statistical tools. Pairwise comparison of seasons created two groups, one with spring/fall grouped together and another with summer/fall/winter. The CAP model found that summer (75\% correct) was the most distinct, while fall (9\% correct) was the least distinguishable (Table 3.5).

The combined dataset for TBARS showed no significant differences between seasons (Table 3.2).

The combined dataset for liver biomarkers showed a significant difference between seasons (Table 3.2). The PCO graph showed that summer and fall had similar distributions, while winter and spring were more variable (Fig. 3.18). Pairwise comparison of seasons showed three groups: summer/fall, winter and spring. The CAP model supported this grouping, showing that spring $(70 \%$ correct) and summer $(60 \%$ correct) were the most distinctive while fall $(26 \%$ correct) and winter (29\% correct) were the least distinctive (Table 3.5).

The combined datasets for kidney and gill biomarkers showed no significant differences between seasons (Table 3.2).

\subsection{3 - Correlation Between Biomarkers, Environmental Conditions and Contaminant Concentrations in Sediments}


Standard length, HSI, condition factor and cellular biomarkers were compared to the other biomarkers, environmental parameters and sediment contaminant concentrations individually using Pearson product-moment correlation. Cellular biomarkers and combined indices were compared against combined environmental data, sediment chemistry (all seasons) and sediment chemistry with pesticides (Spring 2013) using RELATE/BEST.

Halibut SL was significantly correlated with HSI and kidney TBARS (Table 3.6). The correlation with HSI was negative ( $\mathrm{r}=-0.31, \mathrm{p}<0.001)$, while the correlation with kidney TBARS was positive $(r=0.31, p<0.001)$. Standard length significantly and positively correlated with all contaminant concentrations $(\mathrm{p}<0.01)$ and percent fine fraction $(\mathrm{p}<0.001)$ as well as significantly and negatively correlated to temperature at bottom $(\mathrm{p}<0.01)$ and median grain size $(\mathrm{p}<0.001$; Table. 3.7). These correlations indicate that larger fish were found in the back bay where it was warmer with smaller median grain size and higher contaminant concentrations.

HSI was significantly correlated with standard length $(r=-0.31, \mathrm{p}<0.001)$ and strongly correlated to gill TBARS, although not significantly $(r=0.14, p<0.1$; Table 3.6). Compared to sediment parameters, HSI was correlated significantly with median grain size $(r=0.23, \mathrm{p}<0.001)$ and percent fine fraction $(r=-0.22$, $\mathrm{p}<0.5$ ), and negatively correlated with all sediment contaminant concentrations ( $\mathrm{p}<0.01)$ except for $\mathrm{Pb}$ (Table 3.7). These correlations suggest that HSI scores are lower where there are fine-grained sediments with higher contaminant concentrations.

Condition factor significantly correlated to gill EROD $(\mathrm{r}=-0.27, \mathrm{p}<0.01$; Table 3.6). It significantly correlated with environmental parameters: temperature at bottom $(\mathrm{r}=-0.19, \mathrm{p}<0.01)$, salinity at bottom $(\mathrm{r}=-0.16, \mathrm{p}<0.05)$ and rainfall in the season the fish was collected $(\mathrm{r}=0.22, \mathrm{p}<0.01$; Table 3.7). For sediment contaminant concentrations, it correlated well with total pyrethroids, total fipronils and total PBDEs (p-values between 0.05 and 0.1 ), but none were significant (Table 3.7). Since these contaminants were measured in only one 
season and the correlations are relatively weak, more investigation is needed to examine the importance of this observation.

Liver EROD was found to significantly correlate to liver TBARS ( $\mathrm{r}=-0.26$, p<0.001; Table 3.6), but none of the sediment contaminant concentrations individually (Table 3.7). Liver EROD was compared against combined environmental data, sediment chemistry and sediment chemistry with pesticides using RELATE/BEST, but did not correlate significantly with any of them (Tables 3.8, 3.9 and 3.10).

Kidney EROD was found to significantly correlate to liver TBARS $(\mathrm{r}=0.21, \mathrm{p}<0.001)$, kidney TBARS $(\mathrm{r}=0.25, \mathrm{p}<0.05)$, gill EROD $(\mathrm{r}=0.43, \mathrm{p}<0.001)$ and gill TBARS $(\mathrm{r}=0.46, \mathrm{p}<0.001$; Table 3.6$)$. It did not significantly correlate to any of the environmental parameters or sediment contaminant concentrations (Table 3.7). Kidney EROD was compared against combined environmental data, sediment chemistry and sediment chemistry with pesticides using RELATE/BEST and was found to correlate significantly with environmental conditions and sediment chemistry (Tables 3.8, 3.9 and 3.10). The environmental variable that was best correlated was median grain size/salinity $(\rho=0.155, p=0.006)$. The sediment chemistry variable that correlated best was $\mathrm{Cu}(\rho=0.131, \mathrm{p}=0.006)$.

Gill EROD was significantly correlated to condition factor $(r=-0.27$, $\mathrm{p}<0.01)$, kidney EROD $(\mathrm{r}=0.43, \mathrm{p}<0.001)$ and gill TBARS $(\mathrm{r}=0.19, \mathrm{p}<0.001$; Table 3.6). Against environmental parameters it was only significantly correlated to rainfall in season $(\mathrm{r}=-0.20, \mathrm{p}<0.05)$, and had no significant correlations to contaminant concentrations (Table 3.7). Gill EROD was compared against combined environmental data, sediment chemistry and sediment chemistry with pesticides using RELATE/BEST and was found to significantly correlate with each (Tables 3.8, 3.9 and 3.10). The environmental variable that correlated best was median grain size $(\rho=0.154, \mathrm{p}=0.036)$. The sediment chemistry variable that correlated best was $\mathrm{Cu}(\rho=0.159, \mathrm{p}=0.001)$, followed by total PAHs and $\mathrm{Cu}$ $(\rho=0.133, p=0.001)$. The sediment chemistry including pesticides variable that correlated best was $\mathrm{Cu}(\rho=0.143, \mathrm{p}=0.02)$, followed by total PAHs $/ \mathrm{Cu}(\rho=0.106$, $\mathrm{p}=0.02)$ and $\mathrm{Cu} /$ total PBDEs $(\rho=0.102, \mathrm{p}=0.02)$. 
Liver TBARS significantly correlated to liver EROD ( $\mathrm{r}=-0.26, \mathrm{p}<0.001)$, kidney EROD $(r=0.21, p<0.05)$, kidney TBARS $(r=0.19, p<0.05)$ and gill TBARS $(\mathrm{r}=0.24, \mathrm{p}<0.01$; Table 3.6). Against environmental parameters it only significantly correlated to salinity on the bottom $(r=0.23, \mathrm{p}<0.01)$ and the concentration of total PAHs $(\mathrm{r}=0.16, \mathrm{p}<0.5)$ in sediments (Table 3.7). Liver TBARS was compared against combined environmental data, sediment chemistry and sediment chemistry with pesticides using RELATE/BEST and was found to only significantly correlate with the sediment chemistry that included pesticides (Tables 3.8, 3.9 and 3.10). The sediment chemistry variable that correlated best was total PAHS/Cu/Zn/total fipronils $(\rho=0.132, \mathrm{p}=0.001)$.

Kidney TBARS correlated significantly with liver TBARS ( $\mathrm{r}=0.19$, $\mathrm{p}<0.05)$ and kidney EROD $(\mathrm{r}=0.25, \mathrm{p}<0.05$; Table 3.6). There were no significant correlations with environmental parameters or sediment contaminant concentrations (Table 3.7). Kidney TBARS was compared against combined environmental data, sediment chemistry and sediment chemistry with pesticides using RELATE/BEST, but was found not to significantly correlate to any of them (Tables 3.8, 3.9 and 3.10).

Gill TBARS significantly correlated with liver TBARS $(\mathrm{r}=0.24, \mathrm{p}<0.01)$, kidney EROD $(r=0.46, p<0.001)$, and gill EROD $(r=0.19, p<0.05$, Table 3.6). It significantly correlated with percent fine fraction $(\mathrm{r}=0.16, \mathrm{p}<0.05)$, and was strongly correlated $(0.10>\mathrm{p}>0.05)$ with temperature at bottom $(\mathrm{r}=-0.15)$ and median grain size ( $\mathrm{r}=-0.14$; Table 3.7). Against sediment contaminant concentrations, it only strongly correlated with total pyrethroids $(r=0.24, p<0.1)$ and total fipronils $(\mathrm{r}=0.24, \mathrm{p}<0.1)$. Gill TBARS was compared against combined environmental data, sediment chemistry and sediment chemistry with pesticides using RELATE/BEST and was found to significantly correlate with each (Tables 3.8, 3.9 and 3.10). The environmental variable that correlated best was median grain size/salinity $(\rho=0.112, p=0.023)$. The sediment chemistry variable that correlated best was $\mathrm{Cu}(\rho=0.08, \mathrm{p}=0.047)$. The sediment chemistry variable that correlated best was $\mathrm{Cu} /$ total pyrethroids/total fipronils $(\rho=0.098, \mathrm{p}=0.037)$ and $\mathrm{Cu} /$ total fipronils/total PBDEs $(\rho=0.095, \mathrm{p}=0.037)$. 
The dataset with all biomarkers significantly correlated with environmental data, sediment chemistry and sediment chemistry with pesticides using RELATE/BEST (Tables 3.8, 3.9 and 3.10). The environmental variable that correlated best was median grain size $(\rho=0.218, p=0.006)$. For sediment chemistry, the variable that correlated best was $\mathrm{Cu}(\rho=0.142, \mathrm{p}=0.009)$. When compared to sediment chemistry including the pesticides, the variables that correlated strongest were $\mathrm{Cu} /$ total PBDEs $(\rho=0.198, \mathrm{p}=0.001)$.

The dataset for cellular biomarkers was determined to significantly correlate with environmental data, sediment chemistry and sediment chemistry with pesticides using RELATE/BEST (Tables 3.8, 3.9 and 3.10). The environmental variable that was best correlated was median grain size/salinity $(\rho=0.235, p=0.004)$. The sediment chemistry variable that correlated best was $\mathrm{Cu}$ ( $\rho=0.114, \mathrm{p}=0.047)$ with total PAHs $/ \mathrm{Cu}(\rho=0.08, \mathrm{p}=0.047)$ second best, while the sediment chemistry including pesticides variables that correlated best were $\mathrm{Cu}$ $(\rho=0.148, p=0.002)$ and $\mathrm{Cu} /$ total PBDEs $(0.127)$.

The dataset for morphometric biomarkers was determined to significantly correlate with environmental data, sediment chemistry and sediment chemistry with pesticides (Tables 3.8, 3.9 and 3.10). The environmental variable that correlated best was median grain size/temperature/salinity $(\rho=0.074, p=0.007)$ with grain size/temperature $(\rho=0.073, p=0.007)$ a close second. The sediment chemistry variable that was best correlated was $\mathrm{Cu}(\rho=0.068, \mathrm{p}=0.016)$, closely followed by total PAHs/Cu $(\rho=0.065, \mathrm{p}=0.016)$ and $\mathrm{Cu} / \mathrm{Zn}(\rho=0.064, \mathrm{p}=0.016)$. The sediment chemistry including pesticides variable that best correlated was $\mathrm{Zn} /$ total pyrethroids $(\rho=0.126, \mathrm{p}=0.01)$, but the combined $\mathrm{Zn} /$ total pyrethroids/total PBDEs $(\rho=0.122, p=0.01)$ and Zn/total PBDEs $(\rho=0.121$, $\mathrm{p}=0.01)$ were close.

The dataset for EROD was determined to significantly correlate with the environmental data and sediment chemistry, but not the sediment chemistry that included pesticides (Tables 3.8, 3.9 and 3.10). The environmental variable that correlated best was median grain size $(0.215)$, but the combination of grain size and salinity was a close second $(\rho=0.213, p=0.015)$. For the sediment chemistry, 
$\mathrm{Cu}$ was best $(\rho=0.15, \mathrm{p}=0.003)$ with the combination of PAHs and $\mathrm{Cu}$ second best $(\rho=0.142, p=0.003)$.

The dataset for TBARS was determined to significantly correlate with the environmental data and only the sediment chemistry that included pesticides (Tables 3.8, 3.9 and 3.10). The environmental variable that correlated best was median grain size/salinity $(\rho=0.156, p=0.005)$. For the sediment chemistry that included pesticides, total pyrethroids/total fipronils $(\rho=0.125, \mathrm{p}=0.011)$ was best correlated, but total pyrethroids $(\rho=0.12, p=0.011)$ and total pyrethroids/total PBDEs $(\rho=0.119, p=0.011)$ were close.

The dataset for liver biomarkers was not shown to significantly correlate with any of the environmental or sediment chemistry datasets (Tables 3.8, 3.9 and 3.10).

The dataset for kidney biomarkers was significantly correlated to the environmental data and sediment chemistry, but not the sediment chemistry that included pesticides (Tables 3.8, 3.9 and 3.10). The environmental variable that correlated best was the combined median grain size/salinity $(\rho=0.133, p=0.003)$. The sediment chemistry variable that correlated best was $\mathrm{Cu}(\rho=0.103, \mathrm{p}=0.01)$, but $\mathrm{Cu} / \mathrm{Zn}(\rho=0.101, \mathrm{p}=0.01)$ was close.

The dataset for gill biomarkers was significantly correlated to environmental data, sediment chemistry and sediment chemistry with pesticides (Tables 3.8, 3.9 and 3.10). The environmental variable that was best correlated was median grain size $(\rho=0.18, p=0.004)$ but was closely followed by median grain size/salinity $(\rho=0.178, p=0.004)$. The sediment chemistry variable that was best correlated was $\mathrm{Cu}(\rho=0.174, \mathrm{p}=0.001)$. The sediment chemistry including pesticides variable that was best correlated was $\mathrm{Cu}(\rho=0.158, \mathrm{p}=0.0 .029)$, but was closely followed by $\mathrm{Cu} /$ total pyrethroids $(\rho=0.134, \mathrm{p}=0.029)$ and $\mathrm{Cu} /$ total PBDEs $(\rho=0.132, p=0.029)$.

Overall, HSI and condition factor related strongly to sediment parameters and chemistry (Table 3.7), and the combined morphometric index was also correlated to grain size/temperature (Table 3.8) and Zn/pyrethroids (Table 3.10). Tissue biomarkers positively correlated to one another, except for liver EROD 
and liver TBARS which had a negative relationship (Table 3.6). Only two tissue biomarkers significantly correlated to sediment contaminant concentrations (Table 3.6). Liver TBARS positively correlated to PAHs, while gill TBARS positively correlated to total pyrethroids and total fipronils. All tissue biomarkers with significant correlations to sediment parameters had grain size as one of the main components (Table 3.8), and all had $\mathrm{Cu}$ as the main, and only, component for sediment chemistry without pesticides (Table 3.9). When pesticides were included, gill EROD was best correlated to $\mathrm{Cu}$ and gill TBARS to the combination of $\mathrm{Cu} /$ pyrethroids/total fipronils, while liver TBARS was best correlated to the combination of $\mathrm{Cu} / \mathrm{Zn} /$ total fipronils (Table 3.10). Gill biomarkers had the highest correlation of any tissues. For the combined biomarker indices, cellular biomarkers scored best relative to sediment parameters, but all indices included grain size as one of the main components (Table 3.8). Salinity was also a main component in four of the seven combined indices with significant correlation to environmental parameters. For the sediment chemistry that did not include pesticides, all combined indices had $\mathrm{Cu}$ as the main, and only, component (Table 3.9). Gill biomarkers scored best against this sediment chemistry dataset. When pesticides were included, gill was the only combined tissue index to be significant and best correlated to $\mathrm{Cu}$ (Table 3.10). TBARS was significantly correlated to the combination of pyrethroids/total fipronils, while EROD was not significantly correlated to sediment chemistry with pesticides (Table 3.10). The all biomarker index had the highest score of any index compared with the sediment chemistry including pesticides, with the strongest correlation to the combination of $\mathrm{Cu} / \mathrm{PBDEs}$ (Table 3.10).

Based on these results it would seem that $\mathrm{Cu}$ was an especially important contributing variable to the correlations. Pyrethroids and total fipronils were strong factors when pesticides are added to the dataset. PAHs, Zn and PBDEs were also likely contributing factors to the multi-variable comparisons. Gills were the most reflective to sediment contaminant concentration, while the most inclusive indices scored well but were less consistent with specific contaminant correlations. 


\section{4 - Discussion}

\subsection{1 -Environmental Parameters and Biomarkers}

The biomarker data show that juvenile halibut were responding to the gradient in environmental parameters found in the bay. In all cases where biomarkers were significantly correlated with environmental parameters, median grain size had the highest correlation (Table 3.8). In some cases, median grain size was also combined with salinity to form the best correlation. This result most likely reflects the gradient in median grain size from the front to the back bay, with grain size decreasing. Given that salinity fluctuates seasonally in the back bay while it stays relatively constant in the front of the bay, salinity is not likely a significant contributing variable to the relationships observed. Salinity correlated significantly with liver TBARS, but the only other endpoint correlated to liver TBARS was PAH concentrations (Table 3.7). A study conducted in the Tejo estuary in Portugal tested the short term variability of antioxidant defenses and EROD activity in European sea bass (Dicentrarchus labrax), Senegalese sole (Solea senegalensis) and common goby (Pomatoschistus microps) against environmental parameters and determined that environmental factors were not as important as contaminants in driving the biomarker responses measured in this location (Fonseca et al. 2011b). This result has also been found in other studies on EROD (Whyte et al. 2000) and antioxidant defenses in fish inhabiting estuaries (Martnez -'lvarez et al. 2005 ).

\subsection{2 - Tissue Biomarkers}

Biomarkers from liver, kidney and gill tissue showed various degrees of responsiveness to the gradient of sediment contaminants in Mission Bay. EROD and TBARS from each tissue were assessed for differences among sites and seasons, and their correlation to contaminant concentrations measured in the sediment.

Liver has been reported to best reflect exposure to contaminated sediments (van der Oost 2003, Lpez -Galindo et al. 2010). Elevated concentrations of PAHs have been measured in Mission Bay in previous studies (Kaufmann et al. 
2006, Schiff et al. 2011, Lao et al. 2012), and we expected that liver EROD would show a strong response to PAH contamination gradients. However, liver EROD was not able to distinguish variation between sites in Mission Bay, it was only able to distinguish between seasons. Furthermore, this biomarker did not correlate significantly with any environmental parameters or sediment contaminant concentrations. It has been noted in other studies that EROD levels peak around one week after exposure and then return to a basal level over time after depuration (Whyte et al. 2000, Lpez -Galindo et al. 2010). Metals have been shown to be CYP1A inhibitors, especially $\mathrm{Hg}^{2+}, \mathrm{Cu}^{2+}$ and $\mathrm{Zn}^{2+}$ at low concentrations, and have the potential to have synergistic effects on biomarker response when in complex mixtures (Oliveira et al. 2004, Viera et al. 2009, Celender 2011). The front bay has relatively low metal concentrations and "hot spots" of PAH and metal contamination while the back bay has high concentrations of both, especially near Cudahy Creek and Tecolote Creek. Further controlled experiments are needed to determine what is driving the observed response in liver biomarkers in halibut.

Liver TBARS performed much better, as it was able to distinguish between sites and seasons. It correlated significantly to sediment contaminant concentrations with pesticides, but not to environmental parameters or sediment contaminant concentrations that only included $\mathrm{Cu}, \mathrm{Zn}$ and PAHs. Fipronil and its degradates were the compounds that seemed to drive this correlation, although it should be noted that fipronil and its degradates were not detected at Mariners Cove which had the highest mean liver TBARS. Liver biomarkers overall performed poorly; however, there could have been confounding factors that created some of the patterns.

The best liver biomarker was the morphometric hepatosomatic index (HSI). HSI was significantly lower at Cudahy Creek and Tecolote Creek compared to the front bay and middle sites (Fig. 3.3, Table 3.1). Reduced HSI in the presence of contaminated sediments has been seen in rabbitfish (Siganus oramin; Fang et al. 2010), sole (Solea solea; Jebali et al. 2013), winter flounder (Pleuronectes americanus, Pereira et al. 1993) and brown bullhead (Ameiurus 
nebulosus, Yang and Baumann 2006). This could result from increased lipid peroxidation and cell death, which has been observed in the form of hepatic lysosomes (Fang et al. 2010). However, HSI has also been observed to increase in the presence of contaminated sediments for mullet (Liza saliens, Fernandes et al. 2008), Japanese medaka (Oryzias latipes, Zhang and Hu 2008), carp (Labeo rohita, Kumari et al. 2014) American plaice (Hippoglossoides platessoides), yellowtail flounder (Limanda ferruginea), gray sole (Glyptocephalus cynoglossus) and winter flounder (Pleuronectes americanus, Khan 2003). This could be a result of increase in liver size due to induction of the P450 system, hyperplasia (increase in cell number), hypertrophy (increase in cell size), or a combination of these factors (Kumari et al. 2014). A similar biomarker that has been used is the ratio of energy storing lipids to structural lipids in the liver of sole (Solea solea, Amara et al. 2007) and turbot (Scophthalmus maximus, Kerambrun et al. 2012). These studies have found that fish in the presence of contaminated sediment had lower ratios of energy storing lipids, indicative of metabolic demand and increased detoxification enzyme production, which has the potential to lower the fitness of individuals utilizing contaminated habitats. Therefore it seems that HSI is relatively species dependent as well as dependent on the contaminants present in the study area. It appears that halibut in Mission Bay are likely showing the effect of increased metabolic demand on energy stores as well as cell death in the liver via lipid peroxidation in areas of high contaminants, causing a lower HSI value.

Kidney biomarkers likewise did not perform well overall. Kidney EROD was able to distinguish between sites but not seasons, but it correlated significantly with metal contaminants in sediment rather than PAHs. Kidney TBARS could not distinguish between sites or seasons, and did not correlate with environmental parameters or sediment chemistry. Kidneys, despite their important immune and excretory functions, do not appear to be a viable tissue for further use with this species.

Of the three tissues that were analyzed, gill was most sensitive to environmental change. Gill EROD differed significantly among sites, seasons, 
and the combination of site and season (Table 3.2); this was the only individual tissue biomarker to show significance for all three groupings of the PERMANOVA test (the combined morphometric index did as well). In the back bay and middle bay, gill tissue had the lowest EROD levels of all three tissues. However, in the front bay EROD was similar to kidney and liver EROD levels, which could be due in part to metal inhibition affecting gills more strongly in the back bay compared to the front bay (Oliveira et al. 2004, Viera et al. 2009). Gill TBARS was able to distinguish between sites, but not seasons. Both biomarkers also correlated significantly and positively with sediment contaminant concentrations. EROD was more strongly correlated than TBARS, but in the dataset that did not include pesticides, both biomarkers correlated best to $\mathrm{Cu}$ concentrations (Table 3.9). When pesticides were included, EROD still correlated best with $\mathrm{Cu}$ while TBARS correlated best with $\mathrm{Cu}$, pyrethroids and total fipronils (Table 3.10). This is the opposite pattern of what was expected, since EROD has shown to be induced primarily by PAHs and other planar aromatic hydrocarbons (Whyte et al. 2000). Complex mixtures can have inhibitory and multiplicative effects competing with one another (Celander 2011). One explanation of this could be that the breakdown products of these pesticides also cause oxidative stress by creating reactive intermediate compounds and directly producing reactive oxygen species (Ferreira et al. 2005, Silva Barni et al. 2014, Taju et al. 2014). These compounds also co-vary in sediments in the back of Mission Bay, which could result in the statistical results not mirroring the mechanistic induction of EROD versus TBARS. There is also the possibility that contaminants not measured in this study are having an effect on the response of EROD and TBARS in the tissues.

The route of exposure to the contaminants should be considered as well, since sediment and waterborne exposure are not the only ways halibut accumulate these contaminants. Some of the halibut were found to have sediment in their guts, which could be a direct source of sediment-bound contaminants to the fish. Dietary exposure affects the liver and kidneys differently, and exposure through diet has different effects than exposure via the water in terms of bioaccumulation 
and biomarker responses in different tissues (Szebedinsky et al. 2001, Minghetti et al. 2008). This could have contributed to the difference in tissue responses observed here, and a controlled lab study with waterborne versus dietary exposures on California halibut would benefit this interpretation.

It is usually not desirable for tissue biomarkers to fluctuate over seasons in order to better define spatial patterns, although this is usually a confounding factor when dealing with seasonal changes in regards to adult spawning and females with ripe ovaries (van der Oost 2003, Kopecka-Pilarczyk 2013). In this study, however, consideration was given to the effect of rainfall on biomarker response from the watersheds delivering a pulse of contaminants to the bay since only juveniles were used (Kayhanian et al. 2008). The groups from pairwise comparison of the PERMANOVA results didn't always separate Fall from other seasons. One reason could be that the season was defined as September $1^{\text {st }}$ November $30^{\text {th }}$, and the first rainfall event was in the second week of October. Therefore "Fall" had times when it was similar to both the season before it (summer), which was dry, and the season after it (winter), which had several rainfall events. The effects of the rainfall can be seen in the mean biomarker values broken down by season (Table 3.4). Fall had the highest mean values for kidney EROD, gill EROD, liver TBARS, kidney TBARS, and gill TBARS, but only had significant differences for gill EROD and liver TBARS. While a first flush signal is likely contributing to these patterns, studies that wish to further characterize this signal should use short time scale sampling for biomarkers around the first rainfall event, since in this study fish were not collected for up to a week after the first rainfall event. Sampling in this study did not focus on the creek mouths before/after the first rain, rather the effort was spread out over the bay for the remainder of the season so this signal could have been the result of multiple storm events. The sediment characteristics and contaminant concentrations demonstrate that this signal may not be evident for several days following a rainfall, but this time frame will also be highly dependent on the magnitude and duration of the event.

\subsection{3 - Combined Biomarker Indices}


The combined biomarker indices were used to determine if combinations of biomarkers could better distinguish between sites and seasons and correlate to sediment contaminant concentrations. The most inclusive were the datasets for all biomarkers (cellular and morphometric biomarkers). Morphometric biomarkers performed well in the PERMANOVA test (Table 3.2), but had the lowest correlation score with environmental parameters out of any individual biomarker or combined index (Table 3.8). The same is true for the correlation score with sediment chemistry without pesticides (Table 3.9), and with pesticides it was the second worst (Table 3.10). In part this could be due to the fact that HSI and condition factor individually correlated to different environmental parameters, and the only sediment contaminants they both significantly correlated to were fipronil and its degredates, pyrethroids and PBDEs (Table 3.7). The morphometric index may be used to suggest the presence of more contaminated sediments, but was a poor indicator of how cellular biomarkers responded.

The all biomarker and cellular biomarker indices performed well distinguishing sites and seasons and correlated strongly to $\mathrm{Cu}$ and PBDEs. When pesticides were not included, the all biomarker index had one of the strongest correlation scores $(\rho=0.142)$ to any parameter, next to $\operatorname{EROD}(\rho=0.15)$, gill $\operatorname{EROD}(\rho=0.159)$ and gill biomarkers $(\rho=0.174)$. When pesticides were included, the all biomarker index had the highest correlation score $(\rho=0.198)$, followed by gill biomarkers $(\rho=0.158)$ and cellular biomarkers $(\rho=0.148)$. These inclusive indices show that there may be some benefits to using many biomarkers in a combined score system to grade correlation to environmental conditions (cf. van der Oost 2003, Pereira et al. 2010a, 2010b). The inclusive indices also may be benefitting from one or two strong individual tissues or individual biomarkers that make up the bulk of the correlation and are only marginally aided by including additional biomarkers. When considering time and budget concerns for future studies, these most-inclusive indices may not be the most practical. Instead, creating a more refined index from individual tissues that have proven to be 
responsive to spatial gradients and sediment contaminant concentrations would prove most useful.

The combined EROD and TBARS indices were both able to distinguish between sites, but only EROD could also distinguish between seasons. An unexpected pattern occurred when correlating these indices to sediment contaminants. When pesticides were not included, EROD significantly correlated to sediment chemistry while TBARS did not. In this case, EROD best correlated to $\mathrm{Cu}(\rho=0.15)$, and had the combination of PAHs and $\mathrm{Cu}$ second $(\rho=0.142)$. When pesticides were included, EROD did not significantly correlate to sediment chemistry while TBARS did. In this case, TBARS was most significantly correlated to the combination of pyrethroids and total fipronils $(\rho=0.125)$, while no metals were in the top three correlation scores (Table 3.10). Although metals are known to induce oxidative stress (Martnez-'lvarez et al. 2005 ), these pesticides also have been shown to cause similar effects (Ferreira et al. 2005, Silva Barni et al. 2014, Taju et al. 2014). Consequently, the pesticides (or unmeasured compounds that co-occur with the pesticides) may be more potent oxidants or have additive/multiplicative effects with metals on the depletion of anti-oxidant defenses.

Of the three combined tissue indices, liver was the only one that was not able to distinguish between sites (although it was able to distinguish seasons), and did not correlate to sediment chemistry, either with or without pesticides. The pvalue decreased dramatically when pesticides were included in the analysis $(\mathrm{p}=0.935$ to $\mathrm{p}=0.09$; Table 3.10$)$, apparently due to correlations with liver TBARS.

Kidney biomarkers were able to distinguish between sites, but not seasons. When compared to sediment chemistry, kidney biomarkers correlated to the sediment chemistry that did not include pesticides but did not significantly correlate to the dataset that did. Given the poor performance of kidney TBARS individually, kidney EROD seems to be driving these relationships. Due to the highly significant correlation of kidney EROD to gill EROD (Table 3.6) and kidney EROD and gill EROD correlating well to the same sets of sediment 
contaminants (Tables 3.9, 3.10), kidneys do not represent a viable tissue for future studies using these biomarkers.

Gill biomarkers turned out to be the strongest combined index used. It was able to distinguish between sites, but not seasons (which appears to be driven by gill TBARS performing poorly when distinguishing between seasons; Table 3.2). Gill biomarkers correlated significantly with sediment chemistry with and without pesticides, and in both cases most strongly correlated with $\mathrm{Cu}$. Pyrethroids, PAHs and PBDEs also scored well in the correlation analysis. Compared against gill EROD and gill TBARS alone, the combined gill biomarker index actually correlated better to sediment chemistry with and without pesticides (Tables 3.9 and 3.10). The correlation for the combined index appears to be driven more by gill EROD, since its correlation scores were higher than TBARS. This evidence supports using the gill biomarkers individually but also in tandem in future studies.

\subsection{4 - Comparisons to previous juvenile California halibut research}

This is the first study to quantify oxidative stress (in the form of lipid peroxidation) and EROD activity in California halibut. The range of EROD values for this study (liver: 177.2-1670.6 pmol resorufin $\min ^{-1} \mathrm{mg}_{\text {protein }}{ }^{-1}$, kidney: 211.3-752.2 pmol resorufin $\min ^{-1} \mathrm{mg}_{\text {protein }}{ }^{-1}$, gill: 188.9-1158.3 pmol resorufin $\min ^{-1} \mathrm{mg}$ protein ${ }^{-1}$ ) can be compared to other studies that have measured hepatic EROD in other flatfish species. It appears that California halibut have higher EROD expression compared to starry flounder, rock sole and English sole, which were all sampled in northern California and Washington State (Whyte et al. 2000). Compared to flatfish sampled in other contaminated estuaries, it also appears California halibut have higher EROD activity compared to Senegalese sole (Solea senegalensis) from Ria de Aveiro and Tejo estuaries in Portugal (Fonseca et al. 2011a) and similar activity to European flounder (Platichthys flesus) from the Duoro estuary in Portugal and Vistula river estuary in Poland (Kopecka-Pilarczyk 2013). EROD has been quantified in Pacific halibut 
(Hippoglossuss stenolepis), which ranges from California to Alaska (Huggett et al. 2003). The EROD activity in that study was much lower than that presented here (maximum reported mean value $172 \mathrm{pmol}$ resorufin $\mathrm{min}^{-1} \mathrm{mg}$ protein ${ }^{-1}$ ), but those fish were caught in Alaska and were collected in nearshore as well as offshore habitats, so lower levels would be expected in fish farther offshore (SolØ et al. 2009). Hepatic CYP1A activity and bile FACs have been measured in California halibut exposed to sediments from natural oil seeps in Santa Barbara (Seruto et al. 2005). CYP1A activity and bile FAC accumulation were significantly elevated at $66 \%$ and $100 \%$ of naturally-occurring PAH levels, although compared to values seen in exposures to sediments with urban influence, the induction was relatively insensitive (Seruto et al. 2005). This could have been due to the higher composition of low-molecular weight PAHs present in the sediment, inhibition by an unknown compound(s), or a species-specific low induction response. This study had relatively low PAH concentrations (100\% total PAHs $=90 \mu \mathrm{g} \mathrm{g}^{-1}$ sediment) compared to the present study, and Seruto et al. (2005) also used adult male halibut that were hatchery raised. The fact that nave fish did not have a dramatic response requires further attention, but there is also evidence that larger flatfish (Senegalese sole) are less susceptible to liver damage from xenobiotic exposure compared to smaller ones (Costa et al. 2009b). Our study would have benefitted from a comparison of hatchery-raised halibut exposed in the lab or in situ, but no juvenile or adult California halibut were available from southern California hatcheries at the time. Bile FACs and blood cell DNA damage have been reported in California halibut from bays in southern California (Brown and Steinert 2003). That study found a non-significant correlation between biomarkers and PAHs in sediments, as well as a variable relationship between the two biomarkers. However, Brown and Steinert (2003) had low $\mathrm{N}$ values for biomarkers at some sites ( $\mathrm{n}=2$ in San Diego Bay, from only one location), and they also concluded that liver DNA damage would have been a better choice to correlate with bile FACs, as that relationship had been established previously in turbot from southern California (Roy et al. 2003, Brown and Steinert 2003). 
Classes of a phase II enzyme, glutathione S-transferases (GSTs) have previously been identified in California halibut liver (Donham et al. 2007). Of the four isoforms of GST, only two were identified in California halibut ( $\theta$ and $\alpha$ ). The two that were absent $(\pi$ and $\mu$ ) are notable because they are the primary classes expressed in fishes such as rainbow trout and largemouth bass (Donham et al. 2007). Compared to other flatfish, the activity of California halibut's cytosolic GSTs toward 1-chloro-2,4-dinitrobenzene (CDNB) is relatively low. These findings are relevant to this study, since GSTs are responsible for defense against electrophiles and the peroxide products of DNA and lipids that could cause oxidative damage (van der Oost 2003, Donham et al. 2007, Taju et al. 2014). With lower levels of these enzymes, California halibut are potentially more susceptible to xenobiotic exposures than other flatfish species, and further investigation into liver GST activity would be a useful complement to the biomarkers chosen here.

Much of the previous work with California halibut in southern California and northern Baja has focused on their movements between open coastal and embayment habitats (Forrester and Swearer 2002, Fodrie and Herzka 2013), movement within bays in relation to the quality of embayment habitats (Fodrie and Mendoza 2006, Lpez -Rasgado and Herzka 2009), and contribution of nursery habitats to adult stock (Fodrie and Herzka 2008, Fodrie and Levin 2008, Fodrie et al. 2009). These studies provide much insight into habitat usage and movement but struggle to answer the most confounding questions: how and why are halibut moving within embayment habitats as they age? To answer the "how" question would require an intensive tagging study and would not be an easy undertaking, given the estimated 78,000-85,000 resident halibut using the bay between 2003-2004 (Fodrie and Mendoza 2006).

While our study offers no definitive answers as to why halibut distribute themselves in Mission Bay the way they do, it does offer some insight that adds to the existing body of knowledge. Halibut densities were high in the mid-bay sites (Ventura Cove, Fiesta Bay and Crown Point) and relatively low in the front bay at Mariners Cove and the back bay near Tecolote Creek; this result agrees with 
previous studies (Kramer 1991, Fodrie and Mendoza 2006). During the summer 2012, the back bay near Tecolote Creek reached temperatures ranging from 22-28 ${ }^{\circ} \mathrm{C}$. In aquaculture environments, juvenile halibut have been shown to actively avoid temperatures between $24-28{ }^{\circ} \mathrm{C}$ (Mendez et al. 2010) and over $90 \%$ of juvenile halibut experienced mortality at temperatures above $28{ }^{\circ} \mathrm{C}$ in a laboratory study (Madon 2002). The temperature that promotes maximum growth while not creating metabolic stress is around $18.4{ }^{\circ} \mathrm{C}$ (Madon 2002, Mendez et al. 2010). Higher temperatures also drive up the metabolic demand of fish (Madon 2002), which means that they would need to ingest more food to maintain their body weight and potentially increase their exposure to dietary contaminant exposure. The present study found that only larger fish were caught in the back bay, perhaps because they were able to tolerate the conditions compared to smaller halibut. Temperature avoidance may have a strong effect on the distribution of fish near the creek mouth, as no fish were caught at Tecolote Creek during the summer. During the rainy season, the waters cooled near the creek mouths and more halibut were caught in the winter and spring at back bay sites, showing their distribution in this part of the bay is more seasonal. This was observed during field sampling near Tecolote Creek, where halibut were caught with an otter trawl in the deeper waters of the channel more commonly than with a beach seine. Unfortunately, this also corresponds with the time of the year that the most contaminants are being introduced to these parts of the bay.

The front of Mission Bay showed more mixed size classes compared to the middle bay with small halibut and the back bay with larger halibut. Mariners Cove is near the entrance to the bay, and sampling may capture both incoming and outgoing fish, thus increasing variability in size distribution. Kramer (1991) observed that halibut settled on the open coast around $20-30 \mathrm{~mm}$ SL and then had a secondary ingress into bay habitats from $30-50 \mathrm{~mm}$. She also estimated size-at-age for juvenile halibut and determined that halibut start to egress from embayments ( $\sim 1$ year) to deeper subadult and adult habitats at around $160 \mathrm{~mm}$ SL. Given that Mission 
Bay has such a strong sediment gradient, with sandy sediments and a deeper average depth in the front bay compared to the middle and back bay, it's conceivable that some of the fish caught in this area are in the process of "migrating" out of the shallow, fine-grained sediment habitat inside the bay. The halibut from the more polluted areas of the bay could still show some residual enzyme induction, as it takes days to weeks (depending on environmental conditions) for these defense mechanisms to be downregulated (Whyte et al. 2000). The fish in the front bay could also periodically move into the boat basins, where they would be exposed to a pulse of high metal and PAH concentrations, and this exposure also could cause an induction of cellular defenses and evidence of oxidative stress.

\subsection{5 - Conclusions}

Juvenile halibut in Mission Bay show a response to the gradient in sediment contaminant concentrations. There were significant trends in size distribution throughout the bay. The largest fish were found in the back bay with the most polluted sediments, the smallest fish were found in the middle of the bay, and fish of intermediate size were present near the front of the bay. This mixed distribution was the reason why no one size class of halibut was used, rather only fish that were sexually mature were excluded. Of the tissues analyzed, gill was the most responsive to the sediment chemistry gradient and correlated strongly with the contaminants measured. Cellular biomarkers in the liver performed poorly in terms of the response to the contamination gradient, and given the large literature body that uses this tissue in flatfish this result was surprising. However,

the hepatosomatic index was a good general biomarker reflecting areas with high sediment contamination. Kidney was the least responsive of the three tissues used, and was the most difficult to collect enough tissue from to perform meaningful numbers of replicates for biomarker analysis. Future studies using combined indices may benefit from a weighted system that has been employed in histopathological studies (i.e. Costa et al. 2009b) 
The hepatosomatic index, gill EROD and gill TBARS are biomarkers that could be used for further study with this species, and using them in a combined index may be especially useful when correlating the response to sediment chemistry. Liver TBARS was also adequate at distinguishing between polluted sites and cleaner sites, and correlated to the sediment chemistry when pesticides were included. Given the need to maximize time and reduce cost, the hepatosomatic index offers a general biomarker with minimal analytical work that reflects sediment contamination. If utilizing cellular biomarkers, gill would be the most effective tissue for further investigations on this species since multiple biomarkers were shown to be reflective of sediment contaminants. Further work is needed to determine if halibut are primarily exposed to contaminants through sediment/water interactions with the gills or via the diet, although both are likely sources and may play a part in the observed biomarker responses.

Accepting the premise that gills best reflect sublethal stress in Mission Bay, it appears that the areas with highest levels of stress are near the creek mouths and near the front of the bay (possibly due to the presence of boat basins). The middle of the bay, especially near Fiesta Bay, had relatively low levels of stress on juvenile halibut. The pattern of higher biomarker response in the back bay near the creek mouths and in the front bay, which has relatively clean sediments, can be explained by 1) boat basins act as "hot spots" of metals and PAHs that the fish can become exposed to when they migrate into these areas and 2) the movement of halibut within the bay resulted in capture of individuals that had spent time in the more polluted ares in the back of the bay and are migrating towards the mouth. Seasonality did not have a distinct pattern, although the trend of fall having higher mean values of biomarker induction warrants further investigation with more focus on rainfall impact. It appears that the contaminants driving sublethal stress responses in Mission Bay are primarily copper and pesticides.

Given the presence and high densities of juvenile California halibut in bays and estuaries in Southern California, more attention should be paid to this species when designing biomonitoring programs. This study should provide some 
baseline data for comparison with subsequent lab and field studies, as well as offering fruitful avenues for further research on this species. 


\section{5 - Figures and Tables}

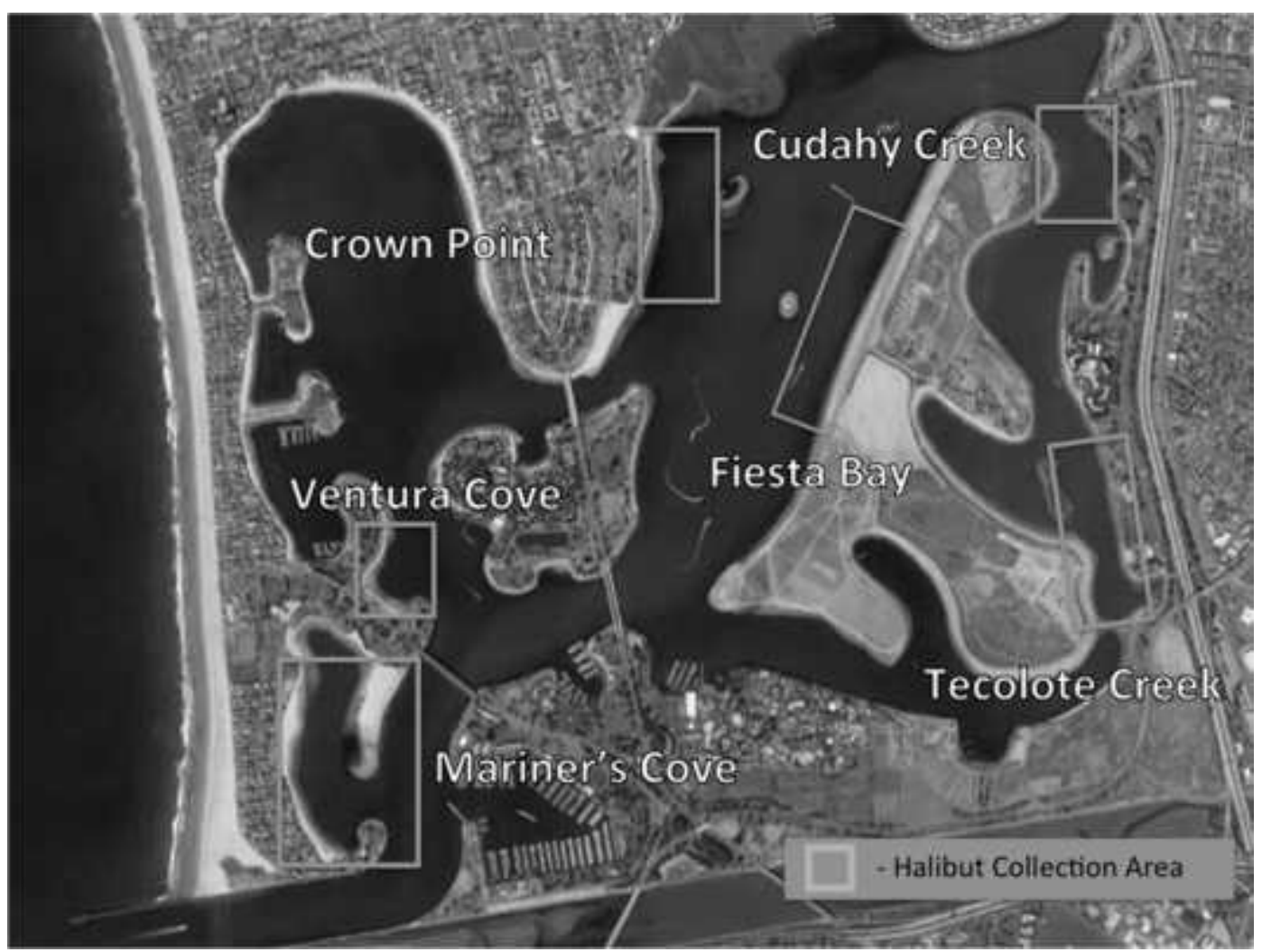

Figure 3.1 Halibut collection areas within Mission Bay. 


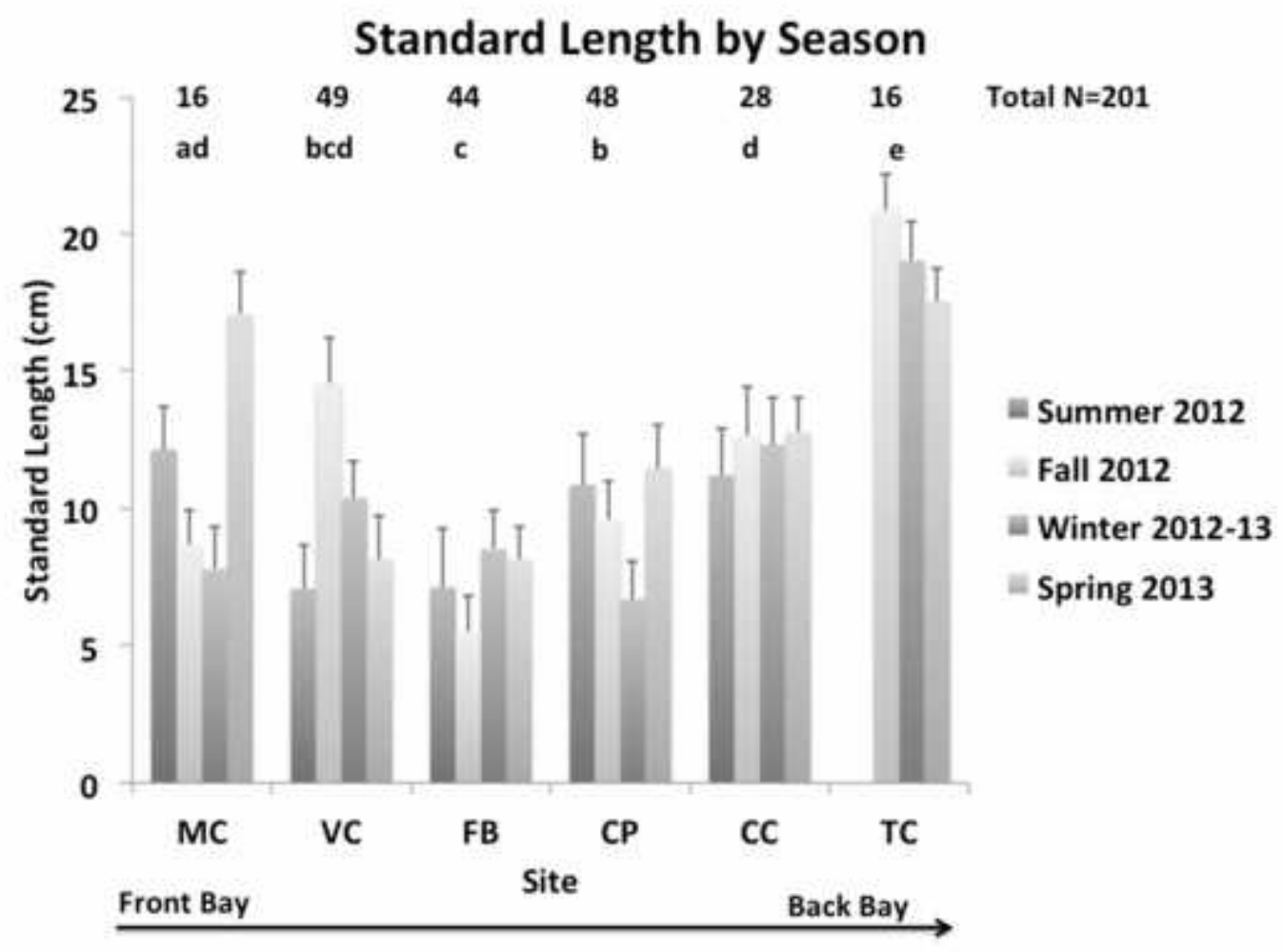

Figure 3.2 Mean standard length by season for halibut collected at each site. Error bars represent one standard deviation. Numbers above the bars represent how many total halibut were caught at that site over the collection period (June 2012-May 2013). Letters represent statistically significant differences based on Kruskal-Wallis analysis with post hoc Mann-Whitney U test. 


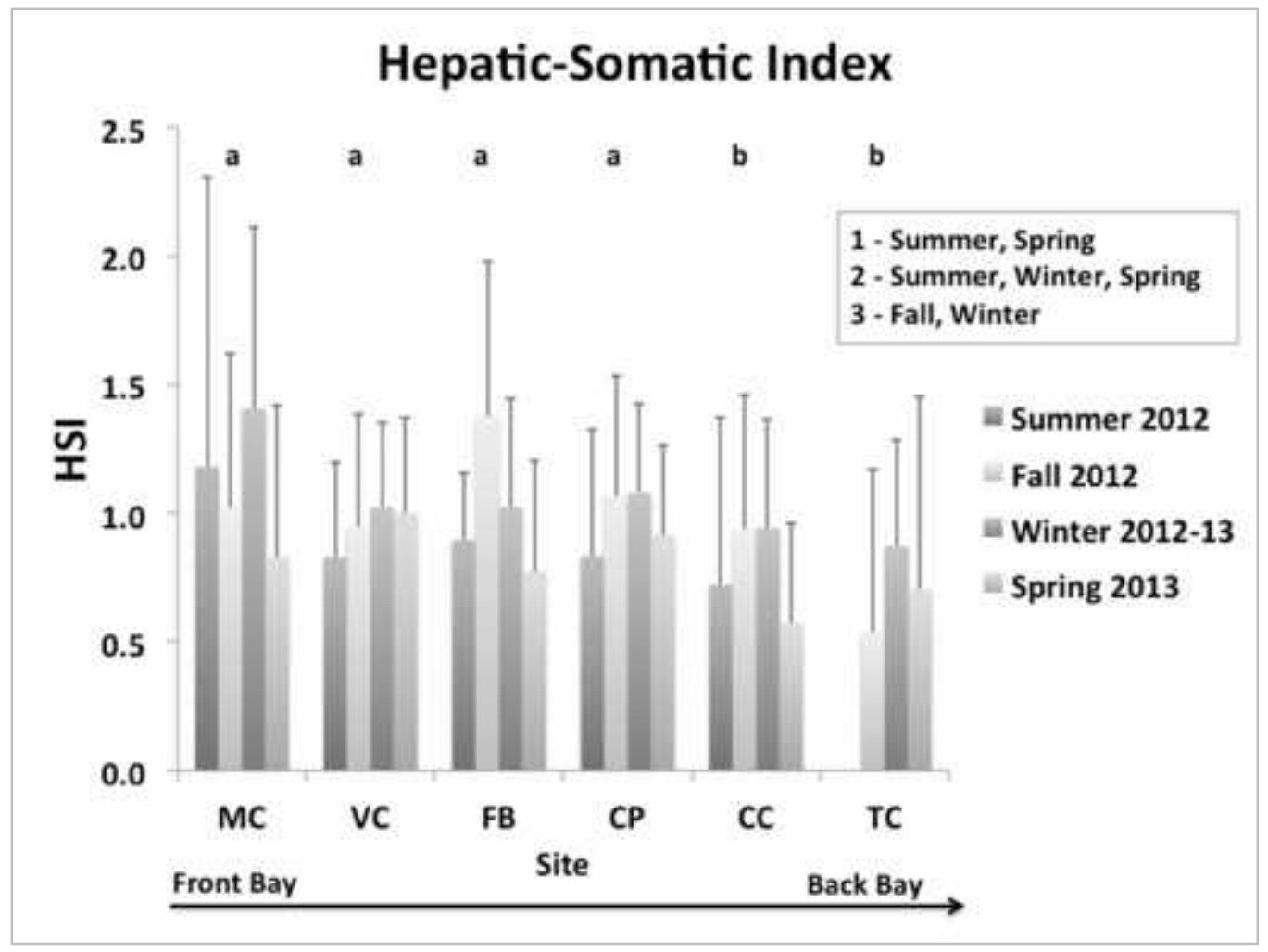

Figure 3.3 Mean hepatosomatic index scores by season for halibut collected at each site. Error bars represent one standard deviation. Letters above bars represent statistically significant differences by site based on Kruskal-Wallis analysis with post hoc Mann-Whitney U test. Numbers in the box represent statistically significant differences by season using the same statistical procedure 




Figure 3.4 Mean condition factor K scores by season for halibut caught at each site. Error bars represent one standard deviation. There were no statistically significant differences in $\mathrm{K}$ between sites or seasons. 




Figure 3.5 Principle components ordination of all biomarkers combined by site. Light triangles: Cudahy Creek, dark triangles: Crown Point, light squares: Tecolote Creek, dark diamonds: Ventura Cove, dark circles: Fiesta Bay, crosses: Mariner's Cove. The circle is a unit circle (radius $=1.0$ ), whose relative size and position of origin is arbitrary with respect to the underlying plot. The three vectors represent correlation of the dataset to concentrations of sediment $\mathrm{Cu}, \mathrm{Zn}$ and total PAHs. 


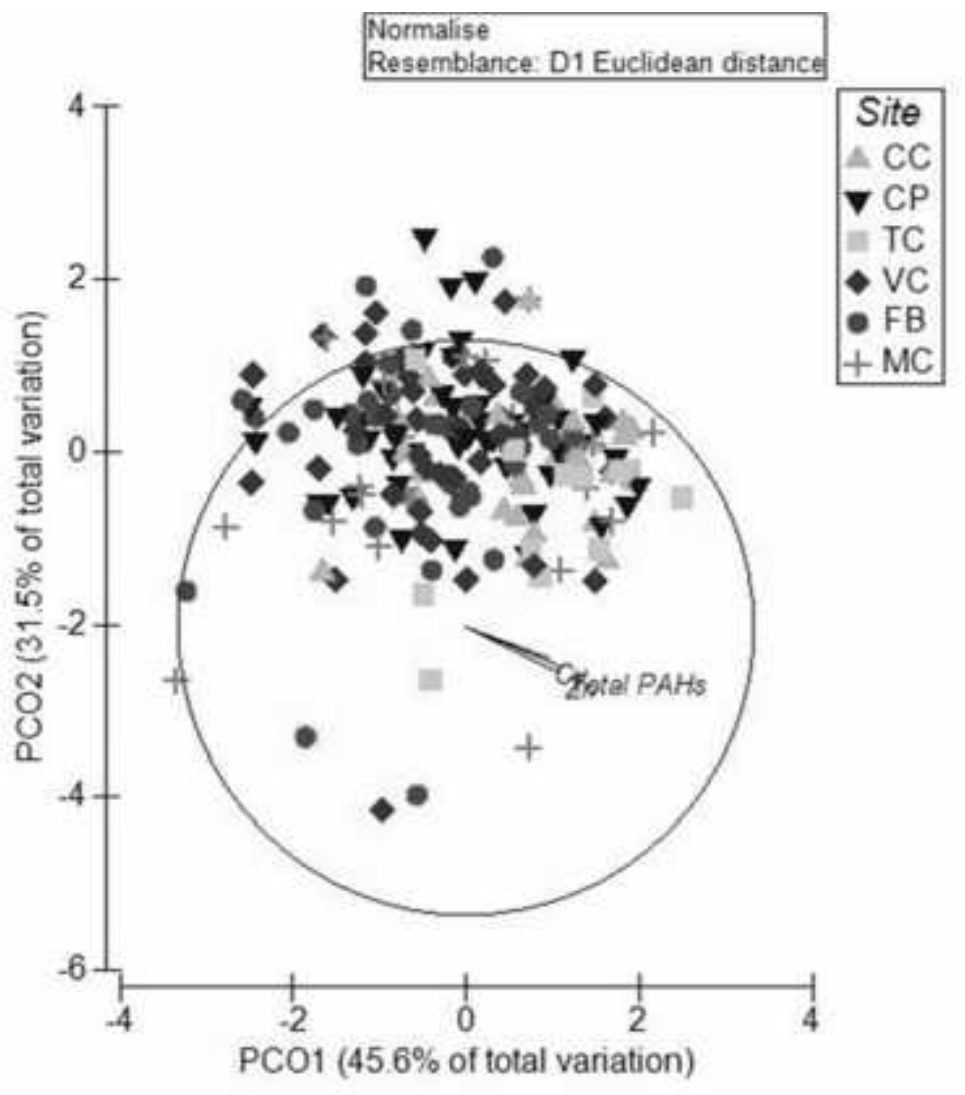

Figure 3.6 Principle components ordination of morphometric biomarkers by site. Light triangles: Cudahy Creek, dark triangles: Crown Point, light squares: Tecolote Creek, dark diamonds: Ventura Cove, dark circles: Fiesta Bay, crosses: Mariner's Cove. The circle is a unit circle (radius $=1.0$ ), whose relative size and position of origin is arbitrary with respect to the underlying plot. The three vectors represent correlation of the dataset to concentrations of sediment $\mathrm{Cu}, \mathrm{Zn}$ and total PAHs. 


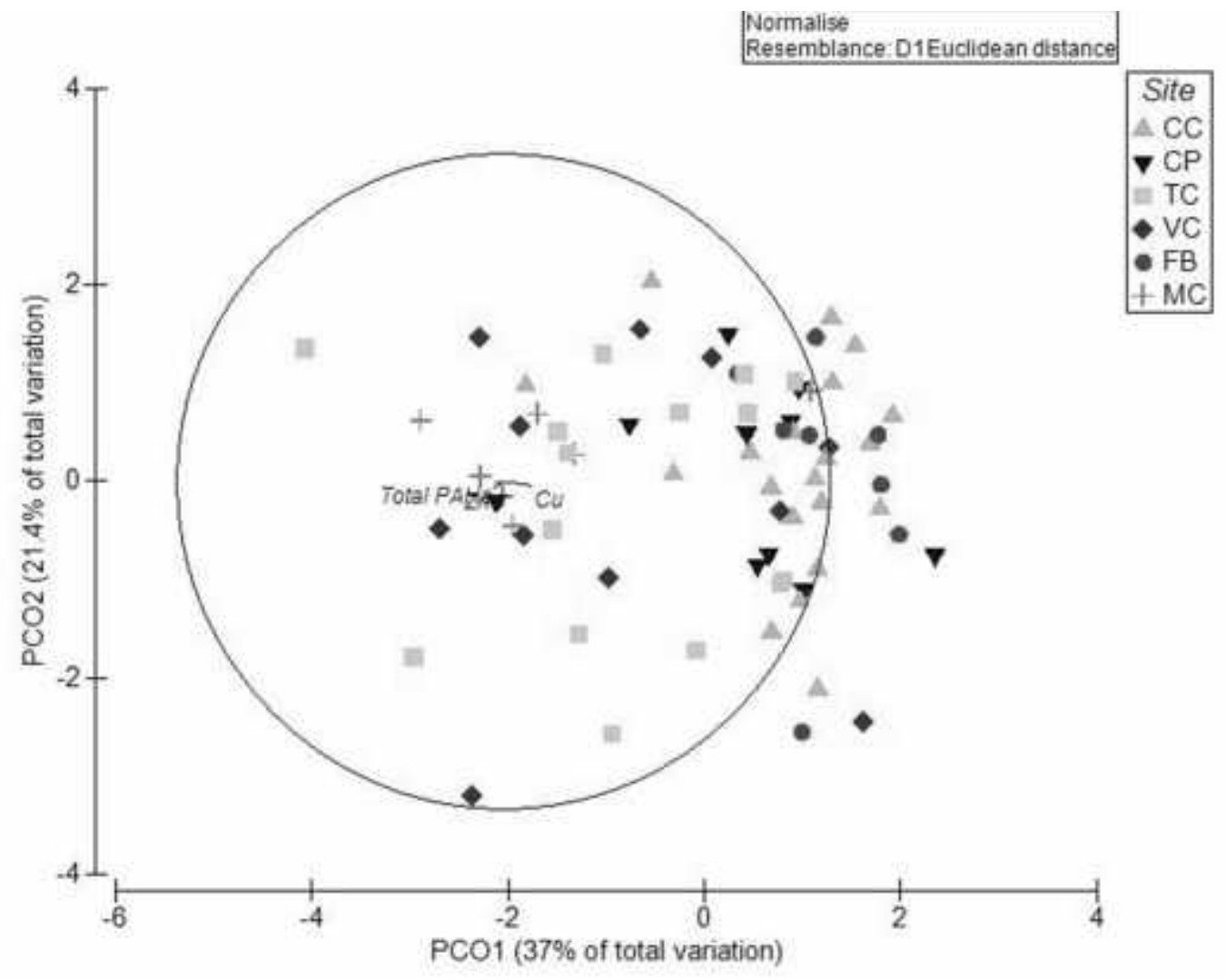

Figure 3.7 Principle components ordination of cellular biomarkers by site. Light triangles: Cudahy Creek, dark triangles: Crown Point, light squares: Tecolote Creek, dark diamonds: Ventura Cove, dark circles: Fiesta Bay, crosses: Mariner's Cove. The circle is a unit circle (radius $=1.0$ ), whose relative size and position of origin is arbitrary with respect to the underlying plot. The three vectors represent correlation of the dataset to concentrations of sediment $\mathrm{Cu}, \mathrm{Zn}$ and total PAHs. 


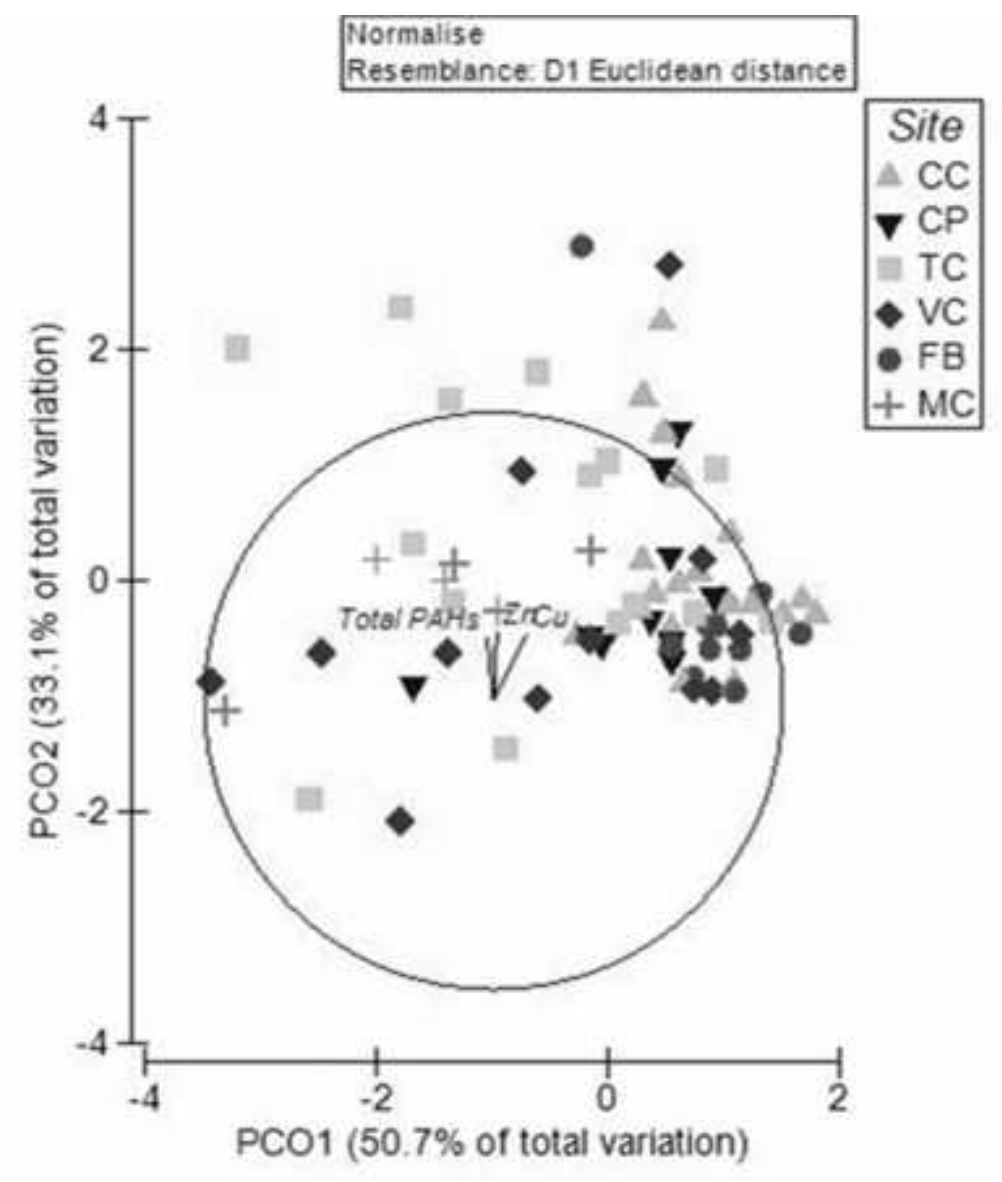

Figure 3.8 Principle components ordination of EROD by site. Light triangles: Cudahy Creek, dark triangles: Crown Point, light squares: Tecolote Creek, dark diamonds: Ventura Cove, dark circles: Fiesta Bay, crosses: Mariner's Cove. The circle is a unit circle (radius $=1.0$ ), whose relative size and position of origin is arbitrary with respect to the underlying plot. The three vectors represent correlation of the dataset to concentrations of sediment $\mathrm{Cu}, \mathrm{Zn}$ and total PAHs. 


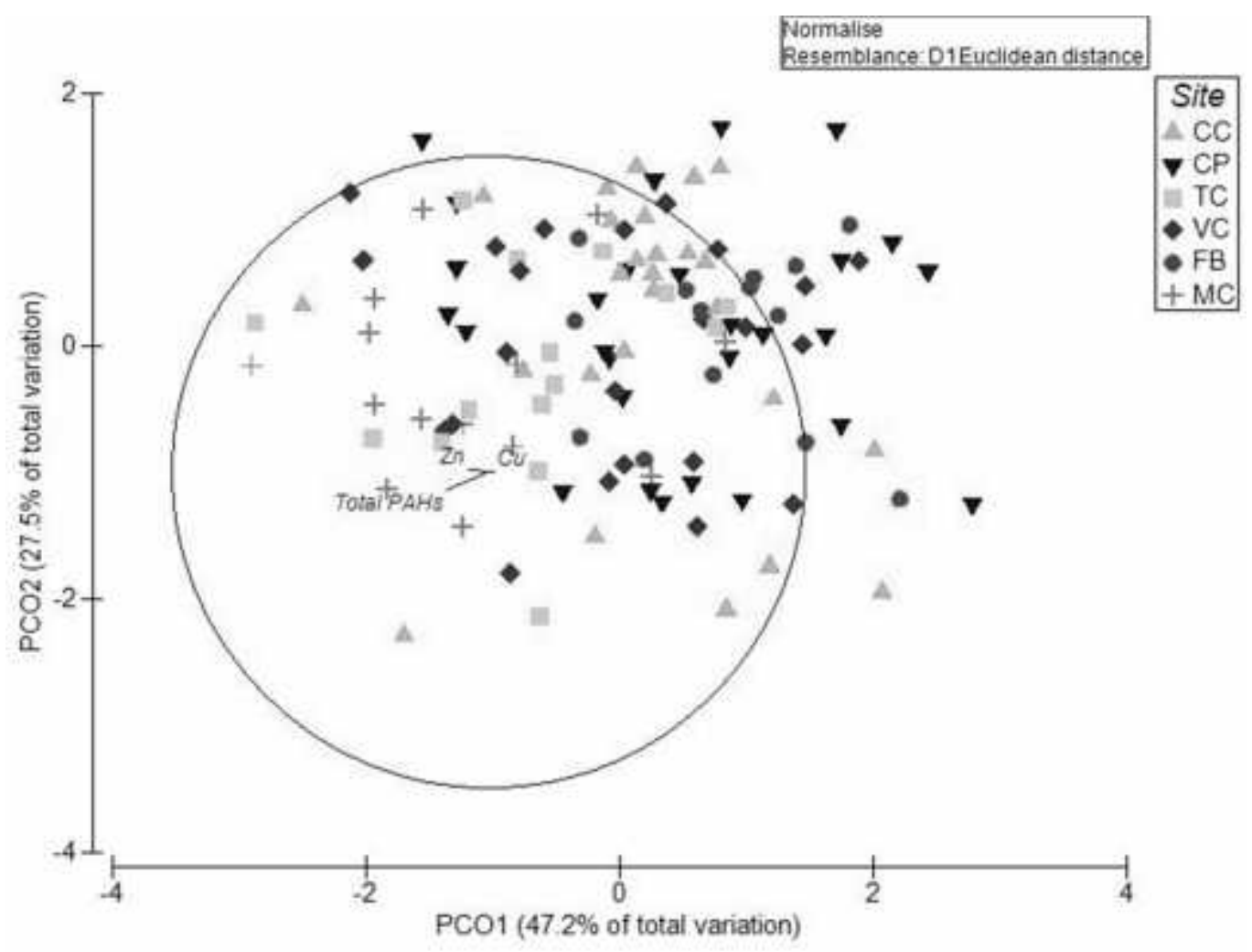

Figure 3.9 Principle components ordination of TBARS by site. Light triangles: Cudahy Creek, dark triangles: Crown Point, light squares: Tecolote Creek, dark diamonds: Ventura Cove, dark circles: Fiesta Bay, crosses: Mariner's Cove. The circle is a unit circle (radius $=1.0$ ), whose relative size and position of origin is arbitrary with respect to the underlying plot. The three vectors represent correlation of the dataset to concentrations of sediment $\mathrm{Cu}$, $\mathrm{Zn}$ and total PAHs. 




Figure 3.10 Principle components ordination of liver biomarkers by site. Light triangles: Cudahy Creek, dark triangles: Crown Point, light squares: Tecolote Creek, dark diamonds: Ventura Cove, dark circles: Fiesta Bay, crosses: Mariner's Cove. The circle is a unit circle (radius $=1.0$ ), whose relative size and position of origin is arbitrary with respect to the underlying plot. The three vectors represent correlation of the dataset to concentrations of sediment $\mathrm{Cu}$, $\mathrm{Zn}$ and total PAHs. 


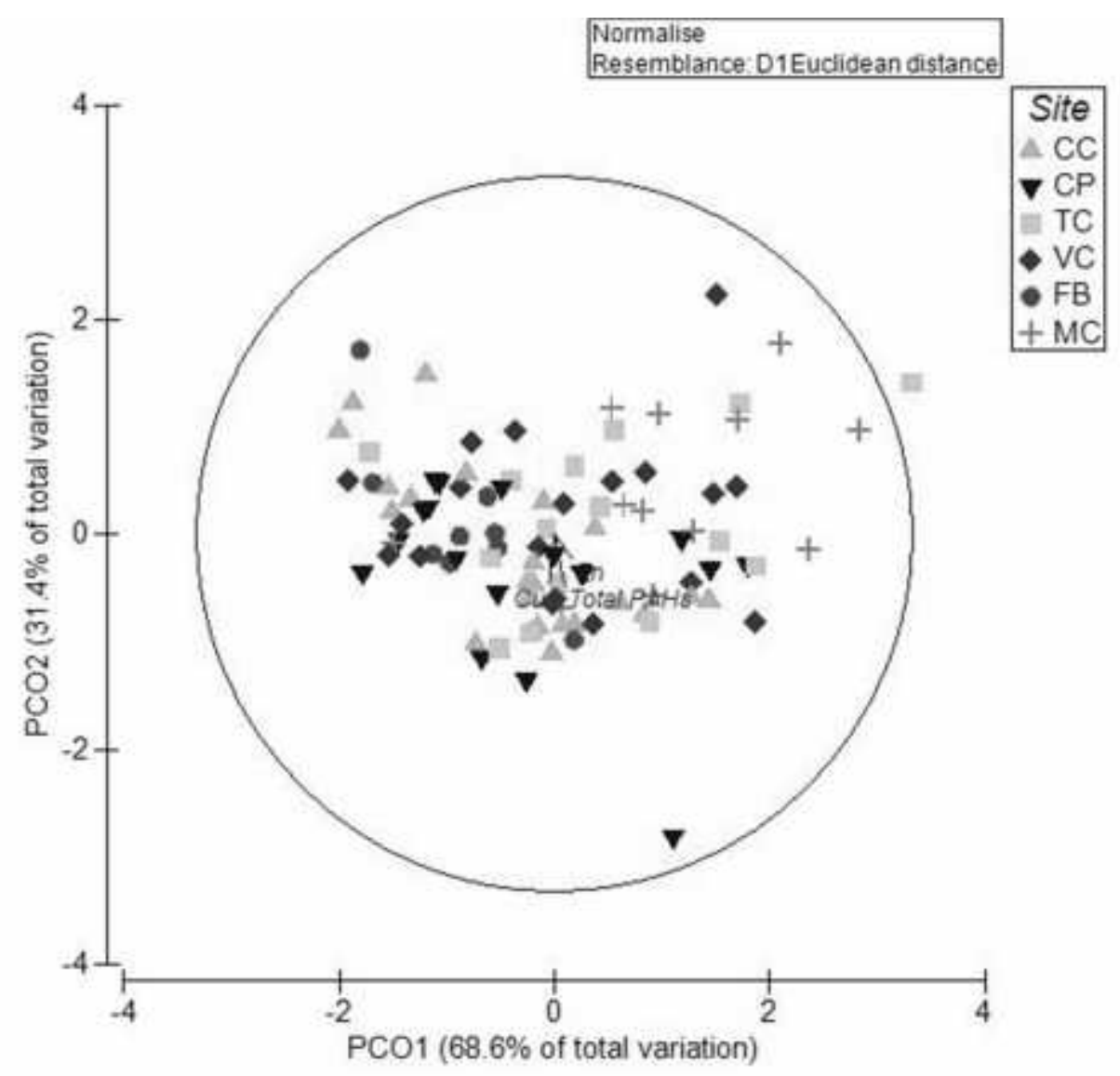

Figure 3.11 Principle components ordination of kidney biomarkers by site. Light triangles: Cudahy Creek, dark triangles: Crown Point, light squares: Tecolote Creek, dark diamonds: Ventura Cove, dark circles: Fiesta Bay, crosses: Mariner's Cove. The circle is a unit circle (radius $=1.0$ ), whose relative size and position of origin is arbitrary with respect to the underlying plot. The three vectors represent correlation of the dataset to concentrations of sediment $\mathrm{Cu}, \mathrm{Zn}$ and total PAHs. 


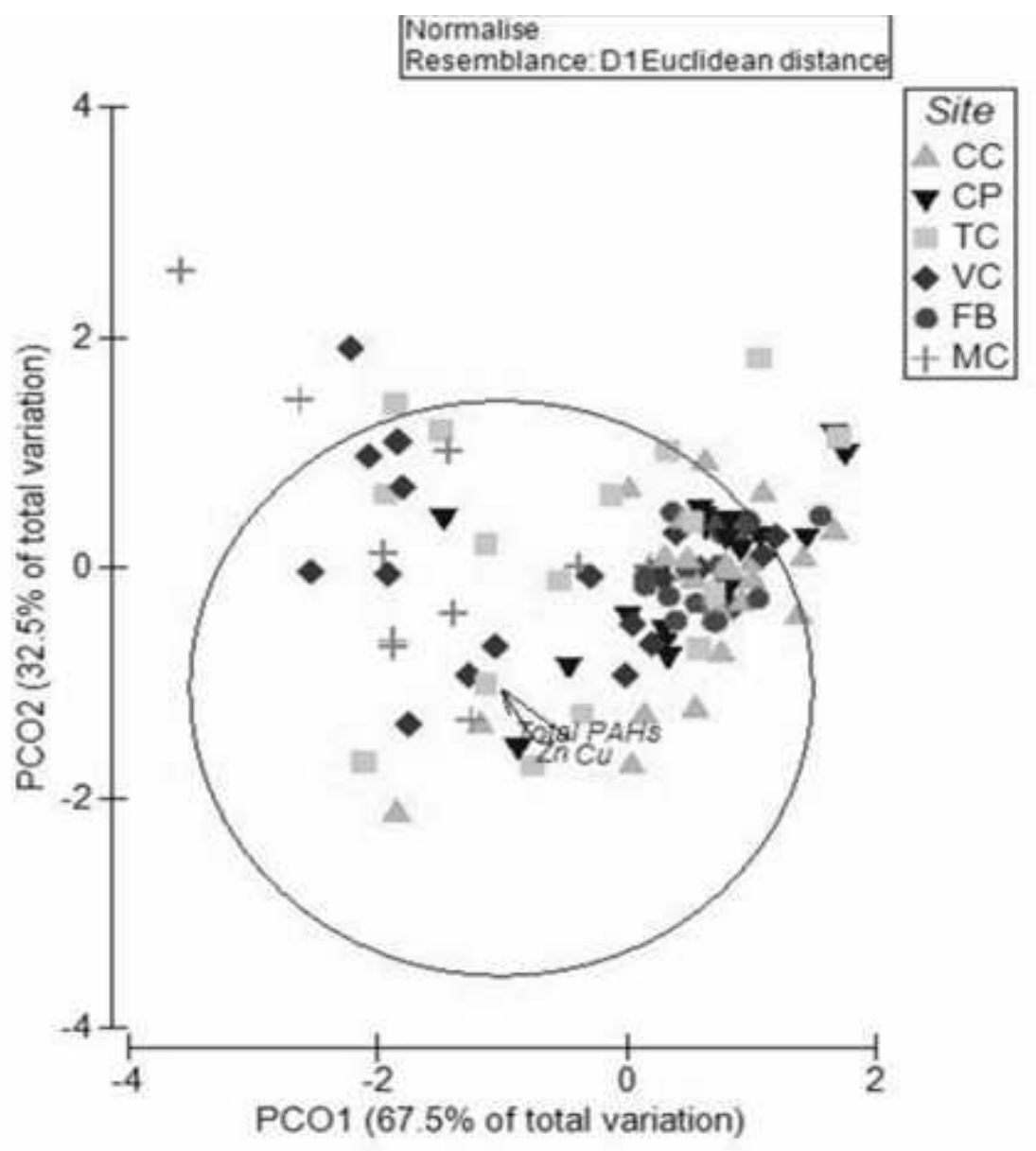

Figure 3.12 Principle components ordination of gill biomarkers by site. Light triangles: Cudahy Creek, dark triangles: Crown Point, light squares: Tecolote Creek, dark diamonds: Ventura Cove, dark circles: Fiesta Bay, crosses: Mariner's Cove. The circle is a unit circle (radius $=1.0$ ), whose relative size and position of origin is arbitrary with respect to the underlying plot. The three vectors represent correlation of the dataset to concentrations of sediment $\mathrm{Cu}$, $\mathrm{Zn}$ and total PAHs. 


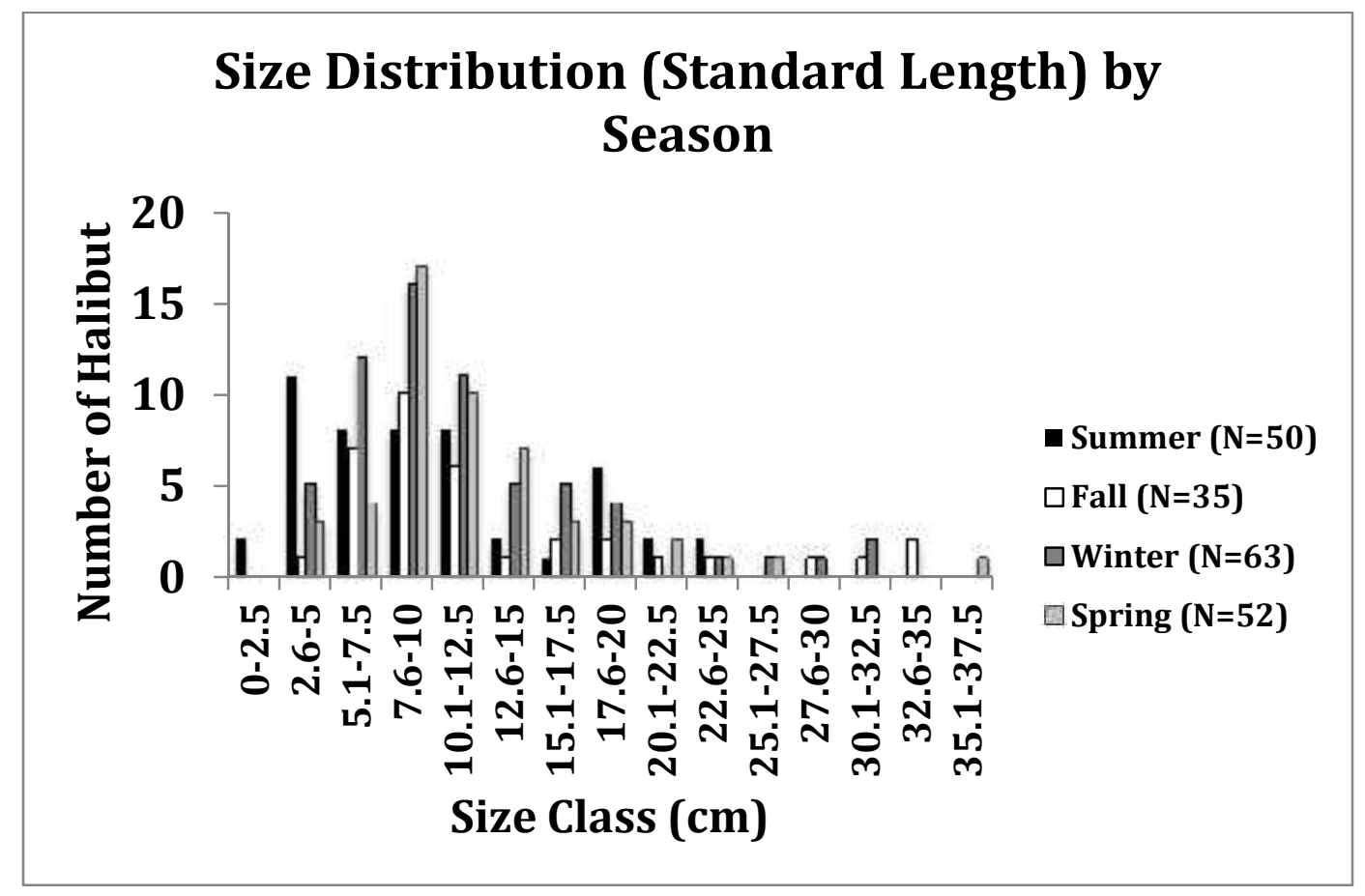

Figure 3.13 Frequency distribution of standard length $(\mathrm{cm})$ for halibut caught during each season. The $\mathrm{x}$-axis shows size classes in $2.5 \mathrm{~cm}$ bins. 


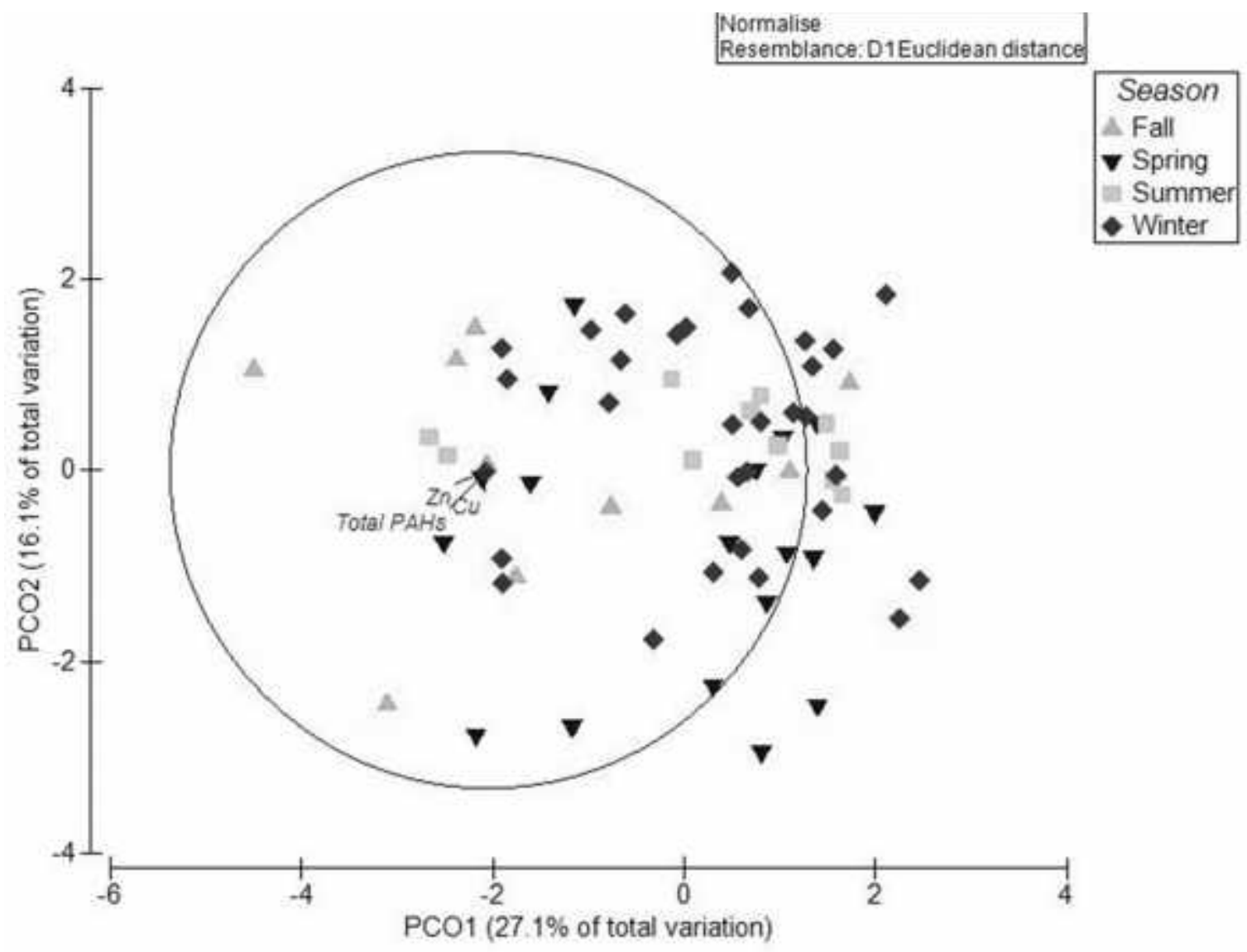

Figure 3.14 Principle components ordination of all biomarkers combined by season. Light triangles: fall, dark triangles: spring, light squares: summer, dark diamonds: winter. The circle is a unit circle (radius $=1.0$ ), whose relative size and position of origin is arbitrary with respect to the underlying plot. The three vectors represent correlation of the dataset to concentrations of sediment $\mathrm{Cu}$, Zn and total PAHs. 




Figure 3.15 Principle components ordination of morphometric biomarkers by season. Light triangles: fall, dark triangles: spring, light squares: summer, dark diamonds: winter. The circle is a unit circle (radius $=1.0$ ), whose relative size and position of origin is arbitrary with respect to the underlying plot. The three vectors represent correlation of the dataset to concentrations to sediment $\mathrm{Cu}$, $\mathrm{Zn}$ and total PAHs. 


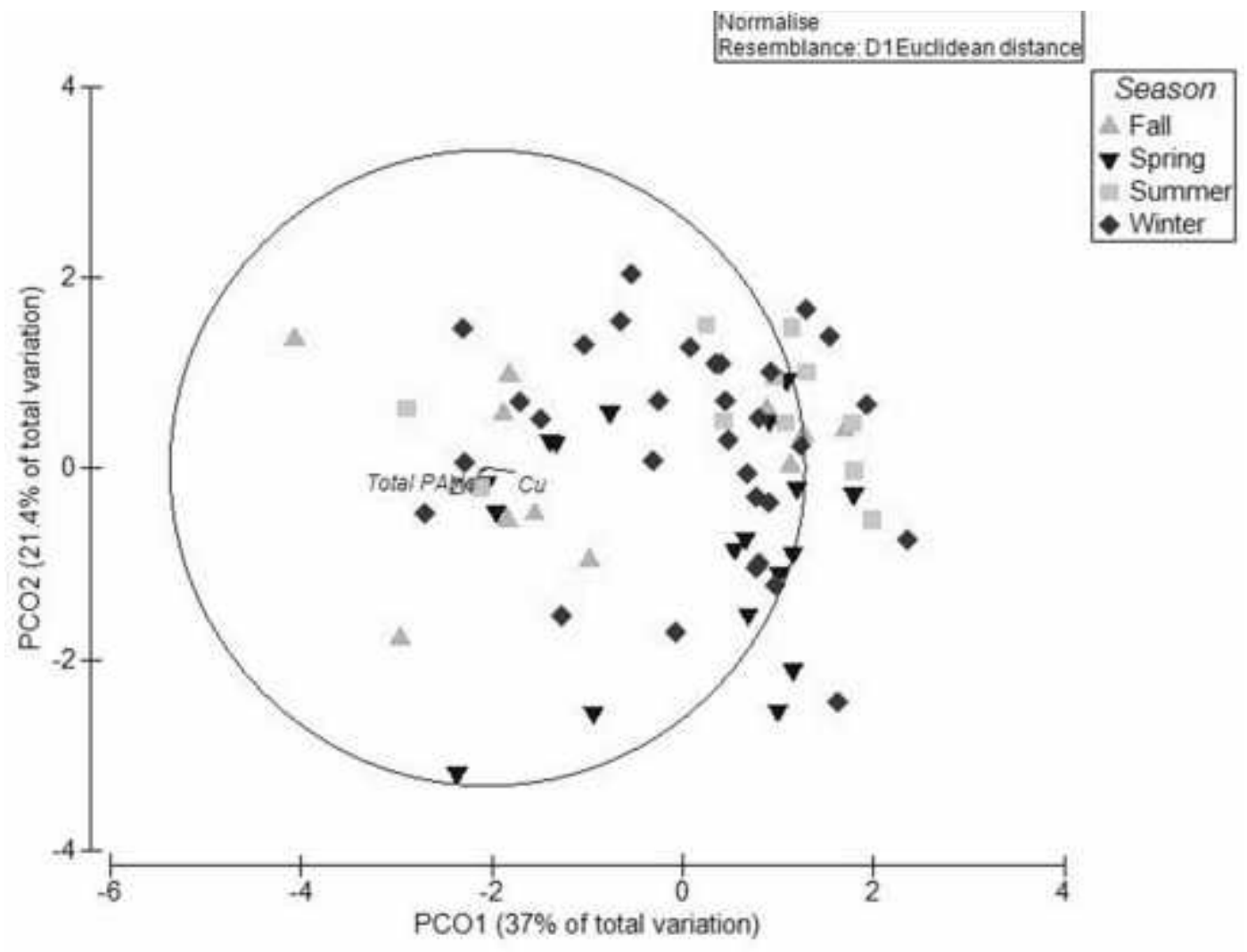

Figure 3.16 Principle components ordination of cellular biomarkers by season. Light triangles: fall, dark triangles: spring, light squares: summer, dark diamonds: winter. The circle is a unit circle (radius $=1.0$ ), whose relative size and position of origin is arbitrary with respect to the underlying plot. The three vectors represent correlation of the dataset to concentrations of sediment $\mathrm{Cu}$, $\mathrm{Zn}$ and total PAHs. 


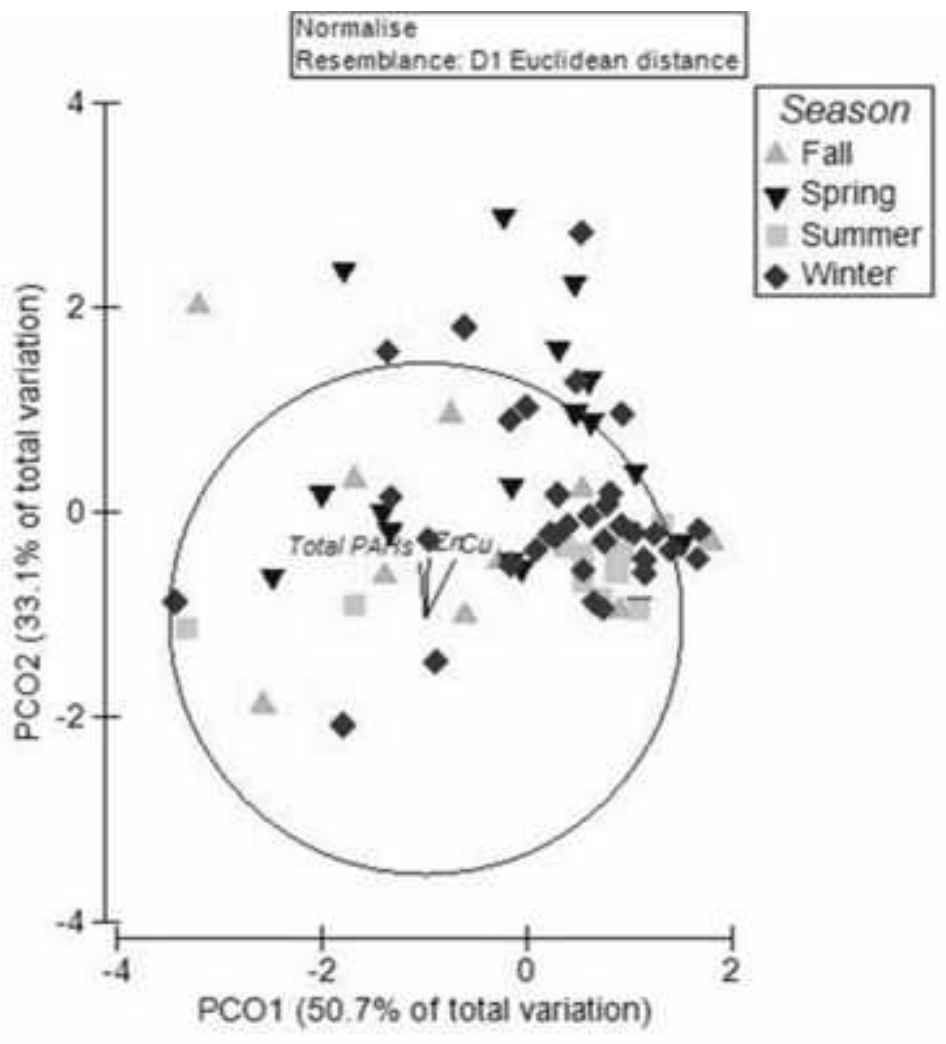

Figure 3.17 Principle components ordination of EROD by season. Light triangles: fall, dark triangles: spring, light squares: summer, dark diamonds: winter. The circle is a unit circle (radius $=1.0$ ), whose relative size and position of origin is arbitrary with respect to the underlying plot. The three vectors represent correlation of the dataset to concentrations of sediment $\mathrm{Cu}$, $\mathrm{Zn}$ and total PAHs. 


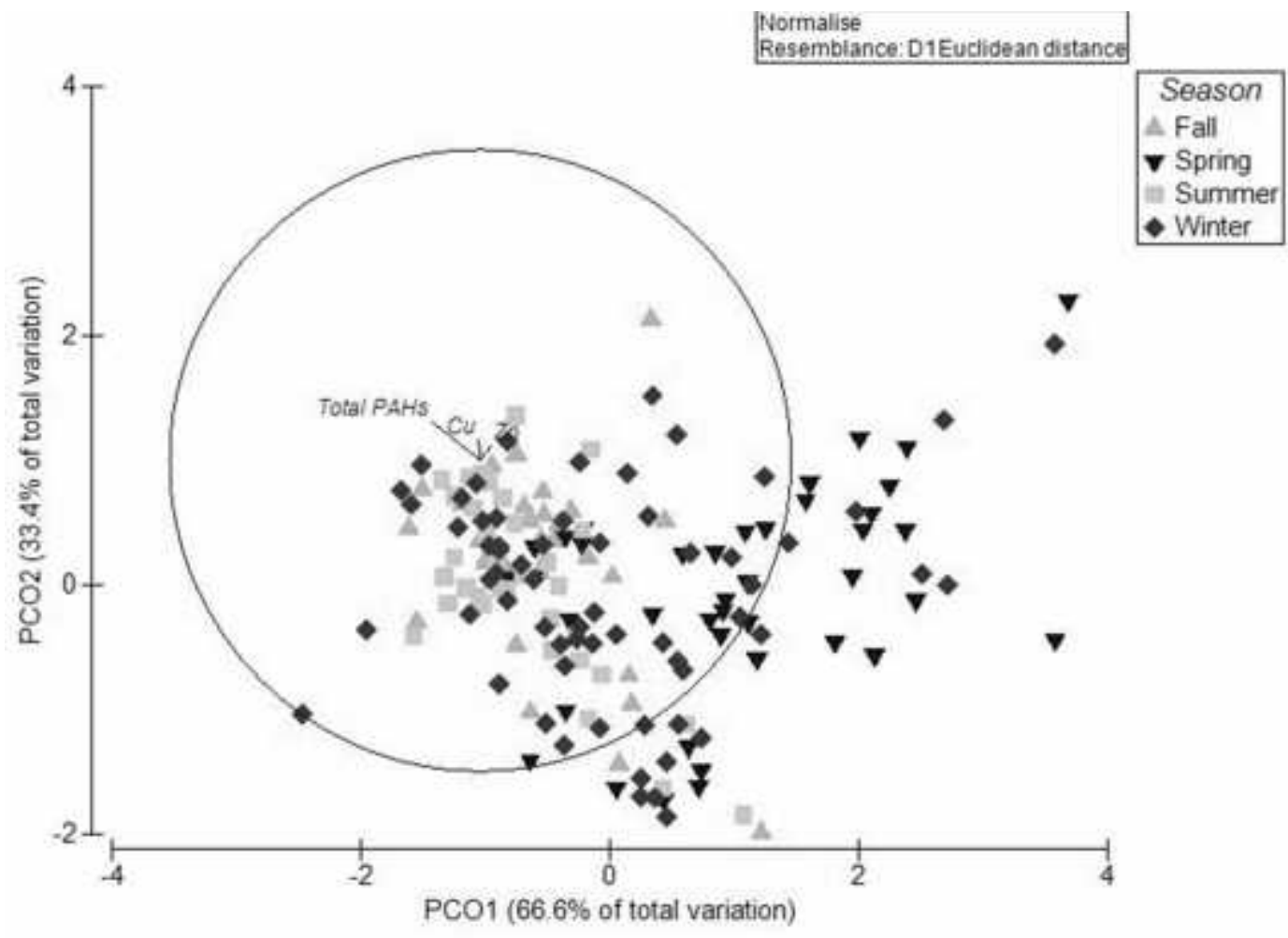

Figure 3.18 Principle components ordination of liver biomarkers by season. Light triangles: fall, dark triangles: spring, light squares: summer, dark diamonds: winter. The circle is a unit circle (radius $=1.0$ ), whose relative size and position of origin is arbitrary with respect to the underlying plot. The three vectors represent correlation of the dataset to concentrations of sediment $\mathrm{Cu}$, $\mathrm{Zn}$ and total PAHs. 


\begin{tabular}{|c|c|c|c|c|c|c|c|c|c|c|}
\hline & & SL & $\mathbf{K}$ & HSI & Liver EROD & Kidney EROD & Gill EROD & Liver TBARS & Kidney TBARS & Gill TBARS \\
\hline \multirow[t]{5}{*}{ MC } & Mean & 11.81 & 1.54 & 1.09 & 458.9 & 423.9 & 457.5 & 0.97 & 0.41 & 0.38 \\
\hline & Std dev & 5.83 & 0.22 & 0.51 & 264.9 & 122.9 & 269.4 & 0.78 & 0.31 & 0.27 \\
\hline & Min & 4.80 & 1.21 & 0.27 & 307.7 & 234.4 & 229.2 & 0.05 & 0.09 & 0.11 \\
\hline & Max & 26.50 & 2.16 & 2.54 & 1499.0 & 641.2 & 1158.3 & 2.70 & 1.21 & 1.16 \\
\hline & $\mathbf{N}$ & 23 & 23 & 23 & 18 & 13 & 11 & 22 & 14 & 22 \\
\hline \multirow[t]{5}{*}{ VC } & Mean & 10.40 & 1.48 & 0.98 & 430.8 & 354.2 & 362.5 & 0.47 & 0.25 & 0.20 \\
\hline & Std dev & 5.80 & 0.17 & 0.28 & 165.1 & 104.6 & 152.3 & 0.50 & 0.27 & 0.15 \\
\hline & Min & 3.60 & 1.23 & 0.47 & 234.6 & 228.0 & 216.2 & 0.01 & 0.00 & 0.03 \\
\hline & Max & 33.00 & 2.27 & 1.73 & 864.0 & 625.2 & 727.0 & 2.24 & 1.35 & 0.70 \\
\hline & $\mathbf{N}$ & 49 & 46 & 46 & 37 & 23 & 20 & 39 & 30 & 31 \\
\hline \multirow[t]{5}{*}{ FB } & Mean & 8.62 & 1.51 & 0.99 & 434.8 & 266.6 & 245.5 & 0.57 & 0.16 & 0.12 \\
\hline & Std dev & 4.60 & 0.20 & 0.31 & 182.3 & 26.4 & 21.7 & 0.74 & 0.11 & 0.07 \\
\hline & Min & 1.83 & 1.18 & 0.51 & 253.7 & 213.8 & 210.6 & 0.03 & 0.00 & 0.05 \\
\hline & Max & 21.40 & 2.23 & 1.69 & 930.5 & 308.8 & 291.8 & 3.21 & 0.53 & 0.32 \\
\hline & $\mathbf{N}$ & 42 & 42 & 42 & 27 & 11 & 17 & 32 & 22 & 28 \\
\hline \multirow[t]{5}{*}{$\mathrm{CP}$} & Mean & 10.84 & 1.45 & 1.00 & 445.3 & 285.0 & 258.5 & 0.59 & 0.32 & 0.12 \\
\hline & Std dev & 6.17 & 0.11 & 0.33 & 257.1 & 60.7 & 46.1 & 0.59 & 0.49 & 0.09 \\
\hline & Min & 3.90 & 1.19 & 0.23 & 177.2 & 211.3 & 218.2 & 0.04 & 0.02 & 0.02 \\
\hline & Max & 35.80 & 1.67 & 1.94 & 1670.6 & 414.7 & 439.6 & 2.51 & 2.91 & 0.48 \\
\hline & $\mathbf{N}$ & 51 & 51 & 50 & 40 & 17 & 20 & 45 & 35 & 31 \\
\hline \multirow[t]{5}{*}{$\mathrm{CC}$} & Mean & 13.99 & 1.45 & 0.80 & 396.4 & 284.8 & 239.5 & 0.65 & 0.30 & 0.16 \\
\hline & Std dev & 6.10 & 0.11 & 0.23 & 99.8 & 38.0 & 36.5 & 0.70 & 0.23 & 0.21 \\
\hline & Min & 5.32 & 1.21 & 0.43 & 276.3 & 226.8 & 188.9 & 0.05 & 0.02 & 0.05 \\
\hline & Max & 32.70 & 1.80 & 1.23 & 694.0 & 365.1 & 329.7 & 2.62 & 0.91 & 1.11 \\
\hline & $\mathbf{N}$ & 34 & 34 & 34 & 31 & 24 & 25 & 34 & 31 & 27 \\
\hline
\end{tabular}




\begin{tabular}{|l|l|c|c|c|c|c|c|c|c|c|}
\hline TC & Mean & 20.11 & 1.49 & 0.82 & 456.2 & 368.1 & 335.8 & 1.00 & 0.40 & 0.24 \\
\hline & Std dev & 6.54 & 0.17 & 0.36 & 157.4 & 133.5 & 115.9 & 0.75 & 0.27 & 0.25 \\
\hline & Min & 11.50 & 1.31 & 0.50 & 261.9 & 234.8 & 212.4 & 0.10 & 0.05 & 0.03 \\
\hline & Max & 31.60 & 1.94 & 2.08 & 766.1 & 752.2 & 600.1 & 3.10 & 0.98 & 1.01 \\
\hline & N & 16 & 16 & 16 & 16 & 15 & 16 & 16 & 16 & 16 \\
\hline
\end{tabular}

Table 3.1 Halibut standard length $(\mathrm{cm})$, morphometric parameters and biomarkers, summarized by site across the sampling period from June 2012 - May 2013. Minimum and maximum values as well as $\mathrm{N}$ values are included. Units for EROD are pmol resorufin min $^{-1} \mathrm{mg}_{\text {protein }}{ }^{-1}$. Units for TBARS are $\mu$ mol MDA g tissue ${ }^{-1}$. $\mathrm{SL}=$ standard length $(\mathrm{cm})$. K=condition factor $\mathrm{K}$. HSI=hepatosomatic index. 


\begin{tabular}{|c|c|c|c|c|c|c|c|c|c|c|c|c|c|c|}
\hline & $\begin{array}{l}\text { All } \\
\text { BM } \\
\end{array}$ & $\begin{array}{c}\text { Cellular } \\
\text { BM }\end{array}$ & $\begin{array}{c}\text { Morpho } \\
\text { BM }\end{array}$ & EROD & TBARS & $\begin{array}{c}\text { Liver } \\
\text { BM }\end{array}$ & $\begin{array}{c}\text { Kidney } \\
\text { BM }\end{array}$ & $\begin{array}{l}\text { Gill } \\
\text { BM }\end{array}$ & $\begin{array}{l}\text { Liver } \\
\text { EROD }\end{array}$ & $\begin{array}{c}\text { Liver } \\
\text { TBARS }\end{array}$ & $\begin{array}{c}\text { Gill } \\
\text { EROD }\end{array}$ & $\begin{array}{c}\text { Gill } \\
\text { TBARS }\end{array}$ & $\begin{array}{c}\text { Kidney } \\
\text { EROD }\end{array}$ & $\begin{array}{l}\text { Kidney } \\
\text { TBARS }\end{array}$ \\
\hline p-value Site & 0.001 & 0.001 & 0.001 & 0.001 & 0.025 & 0.054 & 0.001 & 0.001 & 0.85 & 0.004 & 0.001 & 0.002 & 0.001 & 0.404 \\
\hline $\begin{array}{l}\mathrm{p} \text {-value } \\
\text { Season }\end{array}$ & 0.003 & 0.008 & 0.007 & 0.004 & 0.204 & 0.001 & 0.756 & 0.119 & 0.001 & 0.001 & 0.026 & 0.626 & 0.539 & 0.715 \\
\hline $\begin{array}{l}\mathrm{p} \text {-value } \\
\text { SitexSeason }\end{array}$ & 0.192 & 0.385 & 0.036 & 0.095 & 0.829 & 0.311 & 0.287 & 0.105 & 0.407 & 0.293 & 0.016 & 0.694 & 0.036 & 0.908 \\
\hline $\mathrm{N}$ & 74 & 74 & 211 & 74 & 74 & 169 & 96 & 109 & 169 & 169 & 109 & 109 & 96 & 96 \\
\hline
\end{tabular}

Table 3.2 Results from PERMANOVA analysis of combined biomarker datasets for differences between site, season, and site/season combined. Shaded boxes indicate $\mathrm{p}<0.05$. The $\mathrm{N}$ value for each dataset is in the bottom row. BM=biomarkers. Morpho=morphometric. 


\begin{tabular}{|c|c|c|c|c|c|c|c|c|}
\hline All BM & & & Morpho BM & & & Cellular BM & & \\
\hline $\begin{array}{l}\text { Original } \\
\text { Group }\end{array}$ & \% Correct & $\begin{array}{l}\text { Wrong Group } \\
\text { Chosen Most }\end{array}$ & $\begin{array}{l}\text { Original } \\
\text { Group }\end{array}$ & \% Correct & $\begin{array}{l}\text { Wrong Group } \\
\text { Chosen Most }\end{array}$ & $\begin{array}{l}\text { Original } \\
\text { Group }\end{array}$ & \% Correct & $\begin{array}{l}\text { Wrong Group } \\
\text { Chosen Most }\end{array}$ \\
\hline $\mathrm{CC}$ & 35 & $\mathrm{CP}$ & $\mathrm{CC}$ & 44 & TC & $\mathrm{CC}$ & 40 & FB \\
\hline $\mathrm{CP}$ & 40 & CC,FB & $\mathrm{CP}$ & 10 & FB & $\mathrm{CP}$ & 40 & CC,FB \\
\hline TC & 33 & MC & TC & 69 & $\mathrm{MC}$ & TC & 13 & MC \\
\hline VC & 33 & FB & VC & 2 & FB & VC & 0 & MC \\
\hline FB & 50 & VC & FB & 57 & $\mathrm{TC}, \mathrm{VC}$ & FB & 70 & $\mathrm{CC}, \mathrm{CP}, \mathrm{TC}$ \\
\hline $\mathrm{MC}$ & 29 & $\mathrm{TC}$ & MC & 13 & FB & $\mathrm{MC}$ & 57 & $\mathrm{TC}$ \\
\hline EROD & & & K EROD & & & G EROD & & \\
\hline $\begin{array}{l}\text { Original } \\
\text { Group }\end{array}$ & \% Correct & $\begin{array}{l}\text { Wrong Group } \\
\text { Chosen Most }\end{array}$ & $\begin{array}{l}\text { Original } \\
\text { Group }\end{array}$ & \% Correct & $\begin{array}{l}\text { Wrong Group } \\
\text { Chosen Most }\end{array}$ & $\begin{array}{l}\text { Original } \\
\text { Group }\end{array}$ & \% Correct & $\begin{array}{l}\text { Wrong Group } \\
\text { Chosen Most }\end{array}$ \\
\hline $\mathrm{CC}$ & 30 & FB & $\mathrm{CC}$ & 8 & $\mathrm{FB}$ & $\mathrm{CC}$ & 56 & $\mathrm{CP}$ \\
\hline $\mathrm{CP}$ & 30 & $\mathrm{CC}$ & $\mathrm{CP}$ & 6 & FB & $\mathrm{CP}$ & 50 & $\mathrm{CC}$ \\
\hline $\mathrm{TC}$ & 7 & MC & $\mathrm{TC}$ & 13 & MC & TC & 19 & $\mathrm{MC}, \mathrm{CC}$ \\
\hline $\mathrm{VC}$ & 8 & $\mathrm{MC}$ & $\mathrm{VC}$ & 11 & $\mathrm{MC}$ & $\mathrm{VC}$ & 0 & $\mathrm{MC}$ \\
\hline FB & 80 & CC,TC & FB & 56 & $\mathrm{CC}$ & FB & 24 & CC,CP \\
\hline $\mathrm{MC}$ & 71 & $\mathrm{CP}, \mathrm{FB}$ & $\mathrm{MC}$ & 58 & $\mathrm{TC}$ & $\mathrm{MC}$ & 55 & $\mathrm{CP}$ \\
\hline TBARS & & & L TBARS & & & G TBARS & & \\
\hline $\begin{array}{l}\text { Original } \\
\text { Group }\end{array}$ & \% Correct & $\begin{array}{l}\text { Wrong Group } \\
\text { Chosen Most }\end{array}$ & $\begin{array}{l}\text { Original } \\
\text { Group }\end{array}$ & \% Correct & $\begin{array}{l}\text { Wrong Group } \\
\text { Chosen Most }\end{array}$ & $\begin{array}{l}\text { Original } \\
\text { Group }\end{array}$ & \% Correct & $\begin{array}{l}\text { Wrong Group } \\
\text { Chosen Most }\end{array}$ \\
\hline $\mathrm{CC}$ & 15 & FB & $\mathrm{CC}$ & 6 & VC & $\mathrm{CC}$ & 16 & FB \\
\hline $\mathrm{CP}$ & 30 & CC,TC,FB & $\mathrm{CP}$ & 3 & VC & $\mathrm{CP}$ & 0 & $\mathrm{FB}$ \\
\hline $\mathrm{TC}$ & 33 & $\mathrm{CP}, \mathrm{VC}$ & $\mathrm{TC}$ & 0 & MC & $\mathrm{TC}$ & 19 & $\mathrm{MC}$ \\
\hline $\mathrm{VC}$ & 17 & FB & $\mathrm{VC}$ & 49 & MC & $\mathrm{VC}$ & 15 & MC \\
\hline FB & 70 & $\mathrm{CP}$ & FB & 4 & $\mathrm{VC}$ & FB & 53 & CC \\
\hline MC & 57 & $\mathrm{CP}, \mathrm{TC}, \mathrm{VC}$ & MC & 0 & $\mathrm{TC}$ & $\mathrm{MC}$ & 64 & $\mathrm{CC}, \mathrm{TC}$ \\
\hline
\end{tabular}




\begin{tabular}{|c|c|c|c|c|c|c|c|c|}
\hline L BM & K & K BM & & G BM & & \\
\hline $\begin{array}{l}\text { Original } \\
\text { Group }\end{array}$ & \% Correct & $\begin{array}{l}\text { Wrong Group } \\
\text { Chosen Most }\end{array}$ & $\begin{array}{l}\text { Original } \\
\text { Group }\end{array}$ & \% Correct & $\begin{array}{l}\text { Wrong Group } \\
\text { Chosen Most }\end{array}$ & $\begin{array}{l}\text { Original } \\
\text { Group }\end{array}$ & \% Correct & $\begin{array}{l}\text { Wrong Group } \\
\text { Chosen Most }\end{array}$ \\
\hline CC & 10 & MC & CC & 4 & FB & CC & 16 & FB \\
\hline CP & 3 & MC & CP & 6 & FB & CP & 25 & FB \\
\hline TC & 13 & MC & TC & 13 & MC & TC & 19 & MC \\
\hline VC & 46 & MC & VC & 16 & MC,FB & VC & 10 & MC \\
\hline FB & 0 & MC,VC & FB & 56 & CC & FB & 41 & CP \\
\hline MC & 56 & TC & MC & 67 & TC & MC & 64 & CC,CP,TC,VC \\
\hline
\end{tabular}

Table 3.3 Results of canonical analysis of principal coordinates (CAP) cross-validation for site. Shaded rows show which group of biomarkers is being evaluated. 'Original group' is the site from which the sample was taken out of the model. '\% correct' is how often the model could correctly classify the sample into its original group. 'Wrong group chosen most' is the site to which the model most often assigned the sample, other than its original group. BM=biomarkers.

Morpho=morphometric. L=liver. K=kidneys. $\mathrm{G}=$ gills. $\mathrm{MC}=$ Mariners Cove. $\mathrm{VC}=$ Ventura Cove. FB= Fiesta $\mathrm{Bay}$. $\mathrm{CP}=\mathrm{Crown}$ Point. $\mathrm{CC}=$ Cudahy Creek. $\mathrm{TC}=$ Tecolote Creek. 


\begin{tabular}{|c|c|c|c|c|c|c|c|c|c|c|}
\hline & & SL & $\mathbf{K}$ & HSI & Liver EROD & Kidney EROD & Gill EROD & Liver TBARS & Kidney TBARS & Gill TBARS \\
\hline \multirow{4}{*}{ Summer } & Mean & 10.14 & 1.43 & 0.92 & 350.4 & 325.3 & 327.2 & 0.97 & 0.26 & 0.17 \\
\hline & Std dev & 6.03 & 0.10 & 0.36 & 49.4 & 107.2 & 217.9 & 0.68 & 0.23 & 0.14 \\
\hline & Min & 1.83 & 1.18 & 0.23 & 253.7 & 211.3 & 217.8 & 0.03 & 0.00 & 0.02 \\
\hline & $\mathbf{N}$ & 50 & 50 & 50 & 35 & 22 & 18 & 35 & 25 & 32 \\
\hline \multirow[t]{3}{*}{ Fall } & Mean & 12.79 & 1.49 & 1.03 & 382.1 & 343.9 & 335.4 & 0.99 & 0.43 & 0.26 \\
\hline & Max & 33.00 & 1.65 & 1.69 & 728.8 & 752.2 & 600.1 & 2.70 & 2.91 & 1.01 \\
\hline & $\mathbf{N}$ & 34 & 34 & 34 & 31 & 19 & 13 & 31 & 24 & 25 \\
\hline \multirow[t]{3}{*}{ Winter } & Mean & 11.73 & 1.53 & 1.02 & 429.0 & 314.1 & 276.5 & 0.65 & 0.24 & 0.20 \\
\hline & Std dev & 6.17 & 0.20 & 0.35 & 203.2 & 93.9 & 78.5 & 0.74 & 0.21 & 0.22 \\
\hline & Min & 3.90 & 1.19 & 0.27 & 177.2 & 213.8 & 189.3 & 0.04 & 0.00 & 0.03 \\
\hline \multirow{4}{*}{ Spring } & Std dev & 5.98 & 0.18 & 0.28 & 257.6 & 84.3 & 144.6 & 0.22 & 0.24 & 0.11 \\
\hline & Min & 3.80 & 1.23 & 0.43 & 250.1 & 233.1 & 188.9 & 0.01 & 0.07 & 0.03 \\
\hline & Max & 35.80 & 2.23 & 1.73 & 1670.6 & 557.0 & 727.0 & 0.82 & 1.21 & 0.53 \\
\hline & $\mathbf{N}$ & 52 & 52 & 52 & 40 & 24 & 33 & 52 & 39 & 40 \\
\hline
\end{tabular}

Table 3.4 Halibut standard length (cm), morphometric parameters and biomarkers, summarized by season across all sites between June 2012 and May 2013 Minimum and maximum values for each biomarker as well as $\mathrm{N}$ values are included. Units for EROD are pmol resorufin min $^{-1} \mathrm{mg}_{\text {protein }}{ }^{-1}$. Units for TBARS are $\mu$ mol MDA g tissue ${ }^{-1}$. SL=standard length $(\mathrm{cm})$. $\mathrm{K}=$ condition factor. $\mathrm{HSI}=$ hepatosomatic index. 


\begin{tabular}{|c|c|c|c|c|c|c|c|c|}
\hline All BM & & & Morpho BM & & & Cellular BM & & \\
\hline $\begin{array}{l}\text { Original } \\
\text { Group }\end{array}$ & \% Correct & $\begin{array}{l}\text { Wrong Group } \\
\text { Chosen Most }\end{array}$ & $\begin{array}{l}\text { Original } \\
\text { Group }\end{array}$ & \% Correct & $\begin{array}{l}\text { Wrong Group } \\
\text { Chosen Most }\end{array}$ & $\begin{array}{l}\text { Original } \\
\text { Group }\end{array}$ & \% Correct & $\begin{array}{l}\text { Wrong Group } \\
\text { Chosen Most }\end{array}$ \\
\hline Fall & 55 & $\mathrm{Sp}, \mathrm{Su}$ & Fall & 6 & $\mathrm{~W}$ & Fall & 36 & $\mathrm{Su}$ \\
\hline Spring & 61 & $\mathrm{~F}$ & Spring & 31 & $\mathrm{Su}$ & Spring & 56 & $\mathrm{~W}$ \\
\hline Summer & 75 & $\mathrm{~W}$ & Summer & 62 & $\mathrm{Sp}$ & Summer & 67 & $\mathrm{~W}, \mathrm{~F}$ \\
\hline Winter & 42 & $\mathrm{Sp}$ & Winter & 47 & $\mathrm{Su}$ & Winter & 24 & $\mathrm{Su}$ \\
\hline EROD & & & L EROD & & & G EROD & & \\
\hline $\begin{array}{l}\text { Original } \\
\text { Group }\end{array}$ & \% Correct & $\begin{array}{l}\text { Wrong Group } \\
\text { Chosen Most }\end{array}$ & $\begin{array}{l}\text { Original } \\
\text { Group }\end{array}$ & \% Correct & $\begin{array}{c}\text { Wrong Group } \\
\text { Chosen Most }\end{array}$ & $\begin{array}{l}\text { Original } \\
\text { Group }\end{array}$ & \% Correct & $\begin{array}{c}\text { Wrong Group } \\
\text { Chosen Most }\end{array}$ \\
\hline Fall & 9 & $\mathrm{Su}$ & Fall & 6 & $\mathrm{Su}$ & Fall & 54 & $\mathrm{~W}$ \\
\hline Spring & 44 & $\mathrm{Su}$ & Spring & 63 & $\mathrm{Su}$ & Spring & 6 & $\mathrm{~W}$ \\
\hline Summer & 75 & $\mathrm{~F}$ & Summer & 66 & $\mathrm{~F}$ & Summer & 0 & $\mathrm{~W}$ \\
\hline Winter & 27 & $\mathrm{Su}$ & Winter & 10 & $\mathrm{Su}$ & Winter & 69 & $\mathrm{~F}$ \\
\hline L BM & & & L TBARS & & & & & \\
\hline $\begin{array}{l}\text { Original } \\
\text { Group }\end{array}$ & \% Correct & $\begin{array}{l}\text { Wrong Group } \\
\text { Chosen Most }\end{array}$ & $\begin{array}{l}\text { Original } \\
\text { Group }\end{array}$ & \% Correct & $\begin{array}{l}\text { Wrong Group } \\
\text { Chosen Most }\end{array}$ & & & \\
\hline Fall & 68 & W,Sp & Fall & 26 & $\mathrm{Su}$ & & & \\
\hline Spring & 78 & $\mathrm{~F}, \mathrm{Su}, \mathrm{W}$ & Spring & 70 & $\mathrm{~W}$ & & & \\
\hline Summer & 9 & Sp,W & Summer & 60 & W & & & \\
\hline Winter & 19 & $\mathrm{Sp}$ & Winter & 29 & $\mathrm{Su}$ & & & \\
\hline
\end{tabular}

Table 3.5 Results of canonical analysis of principal coordinates (CAP) cross-validation for season. Shaded rows show which group of biomarkers is being evaluated. 'Original group' is the season from which the sample was taken out of the model. ' $\%$ correct' is how often the model could correctly classify the sample into its original group. 'Wrong group chosen most' is the season to which the model most often assigned the sample, other than its original group. BM=biomarkers.

Morpho=morphometric. L=liver. K=kidneys. G=gills. Su=summer. F=fall. W=winter. Sp=spring. 


\begin{tabular}{|c|c|c|c|c|c|c|c|c|c|}
\hline & $\begin{array}{c}\text { Standard } \\
\text { Length }\end{array}$ & HSI & K & $\begin{array}{c}\text { Liver } \\
\text { EROD }\end{array}$ & $\begin{array}{c}\text { Liver } \\
\text { TBARS }\end{array}$ & $\begin{array}{c}\text { Kidney } \\
\text { EROD }\end{array}$ & $\begin{array}{c}\text { Kidney } \\
\text { TBARS }\end{array}$ & $\begin{array}{c}\text { Gill } \\
\text { EROD }\end{array}$ & $\begin{array}{c}\text { Gill } \\
\text { TBARS }\end{array}$ \\
\hline Standard Length & 1 & $-0.31^{* * * *}$ & -0.09 & $-0.15^{*}$ & -0.1 & 0.15 & $0.31^{* * * *}$ & 0.11 & 0.13 \\
\hline HSI & & 1 & $0.11^{*}$ & 0.03 & -0.01 & -0.05 & -0.07 & -0.07 & $0.14^{*}$ \\
\hline K & & & 1 & -0.02 & 0.01 & -0.15 & -0.01 & $-0.27^{* * *}$ & -0.05 \\
\hline Liver EROD & & & & 1 & $-0.26^{* * * *}$ & 0.15 & -0.06 & 0.1 & -0.01 \\
\hline Liver TBARS & & & & & 1 & $0.21^{* *}$ & $0.19^{* *}$ & 0.1 & $0.24^{* * *}$ \\
\hline Kidney EROD & & & & & & 1 & $0.25^{* *}$ & $0.43^{* * * *}$ & $0.46^{* * * *}$ \\
\hline Kidney TBARS & & & & & & & 1 & 0.1 & 0.13 \\
\hline Gill EROD & & & & & & & & 1 & $0.19^{* *}$ \\
\hline Gill TBARS & & & & & & & & & 1 \\
\hline
\end{tabular}

Table 3.6 Pearson product-moment correlation scores for halibut morphometrics and biomarker correlations.

Shaded boxes indicate significant $\mathrm{p}$-values. ${ }^{*} \mathrm{p}<0.1,{ }^{* *} \mathrm{p}<0.05,{ }^{* * *} \mathrm{p}<0.01,{ }^{* * * *} \mathrm{p}<0.001$ 


\begin{tabular}{|c|c|c|c|c|c|c|c|c|c|c|c|c|}
\hline & $\begin{array}{c}\text { Temp } \\
\text { at } \\
\text { Bottom }\end{array}$ & $\begin{array}{c}\text { Salinity } \\
\text { at } \\
\text { Bottom }\end{array}$ & $\begin{array}{l}\text { Rainfall } \\
\text { in } \\
\text { Season }\end{array}$ & $\begin{array}{c}\text { Median } \\
\text { Grain } \\
\text { Size }\end{array}$ & $\begin{array}{l}\text { Percent } \\
\text { Fine } \\
\text { Fraction }\end{array}$ & $\begin{array}{c}\text { Total } \\
\text { Pyrethroids }\end{array}$ & $\begin{array}{c}\text { Total } \\
\text { Fipronils }\end{array}$ & $\begin{array}{c}\text { Total } \\
\text { PBDEs }\end{array}$ & $\begin{array}{c}\text { Sediment } \\
\mathrm{Cu}\end{array}$ & $\begin{array}{c}\text { Sediment } \\
\text { Zn }\end{array}$ & $\begin{array}{c}\text { Sediment } \\
\text { Pb }\end{array}$ & $\begin{array}{l}\text { Total } \\
\text { PAHs }\end{array}$ \\
\hline $\begin{array}{l}\text { Standard } \\
\text { Length }\end{array}$ & $-0.19 * * *$ & -0.09 & 0.09 & $-0.31^{* * * *}$ & $0.33^{* * * *}$ & $0.51^{* * * *}$ & $0.50^{* * * *}$ & $0.43^{* * * *}$ & $0.38^{* * * *}$ & $0.41^{* * *}$ & $0.39 * * *$ & $0.32^{* * * *}$ \\
\hline HSI & -0.02 & 0 & 0.1 & $0.23^{* * * *}$ & $-0.22^{* *}$ & $-0.30 * *$ & $-0.28^{* *}$ & $-0.30^{* *}$ & $-0.15^{* *}$ & $-0.16^{* *}$ & -0.03 & $-0.20^{* * *}$ \\
\hline $\mathbf{K}$ & $-0.19 * * *$ & $-0.16^{* *}$ & $0.22^{* * *}$ & 0.04 & -0.06 & $-0.23^{*}$ & $-0.21^{*}$ & $-0.22^{*}$ & -0.01 & -0.01 & -0.01 & -0.03 \\
\hline $\begin{array}{l}\text { Liver } \\
\text { EROD }\end{array}$ & -0.12 & -0.12 & 0.09 & 0 & 0.08 & -0.11 & -0.13 & -0.1 & -0.01 & -0.02 & -0.04 & -0.05 \\
\hline $\begin{array}{c}\text { Liver } \\
\text { TBARS }\end{array}$ & 0.09 & $0.23^{* * *}$ & -0.12 & -0.07 & 0.02 & 0.08 & 0.07 & 0.14 & .12 & 0.12 & -0.17 & $0.16^{* *}$ \\
\hline $\begin{array}{c}\text { Kidney } \\
\text { EROD }\end{array}$ & -0.13 & 0.03 & -0.09 & 0 & 0.03 & -0.14 & -0.15 & -0.17 & 0.05 & 0.03 & -0.19 & -0.01 \\
\hline $\begin{array}{l}\text { Kidney } \\
\text { TBARS }\end{array}$ & 0.05 & -0.10 & -0.12 & -0.07 & 0.07 & 0.13 & 0.13 & 0.13 & 0.08 & 0.08 & 0.04 & 0.11 \\
\hline $\begin{array}{c}\text { Gill } \\
\text { EROD }\end{array}$ & 0.05 & 0.16 & $-0.20^{* *}$ & 0.16 & -0.15 & -0.13 & -0.16 & -0.23 & -0.11 & -0.11 & -0.23 & -0.05 \\
\hline $\begin{array}{c}\text { Gill } \\
\text { TBARS }\end{array}$ & $-0.15^{*}$ & -0.06 & 0.03 & $-0.14^{*}$ & $0.16^{* *}$ & $0.24^{*}$ & $0.24^{*}$ & 0.19 & 0.10 & 0.12 & 0.1 & .05 \\
\hline
\end{tabular}

Table 3.7 Pearson product-moment correlation scores for halibut morphometrics and biomarkers and their correlations to environmental conditions and sediment contaminant concentrations. Shaded boxes indicate significant $p$-values. ${ }^{*} p<0.1$, ** $\mathrm{p}<0.05$, *** $\mathrm{p}<0.01$, **** $\mathrm{p}<0.001$ 


\begin{tabular}{|c|c|c|c|c|c|c|c|c|c|c|c|c|c|c|c|}
\hline & & $\begin{array}{l}\text { All } \\
\text { BM }\end{array}$ & $\begin{array}{l}\text { Cellular } \\
\text { BMs }\end{array}$ & Morpho & EROD & TBARS & $\begin{array}{l}\text { Liver } \\
\text { BM }\end{array}$ & $\begin{array}{l}\text { Kidney } \\
\text { BM }\end{array}$ & $\begin{array}{l}\text { Gill } \\
\text { BM }\end{array}$ & $\begin{array}{l}\text { Liver } \\
\text { EROD }\end{array}$ & $\begin{array}{l}\text { Liver } \\
\text { TBARS }\end{array}$ & $\begin{array}{l}\text { Gill } \\
\text { EROD }\end{array}$ & $\begin{array}{l}\text { Gill } \\
\text { TBARS }\end{array}$ & $\begin{array}{l}\text { Kidney } \\
\text { EROD }\end{array}$ & $\begin{array}{l}\text { Kidney } \\
\text { TBARS }\end{array}$ \\
\hline RELATE & Significance & 0.006 & 0.004 & 0.007 & 0.015 & 0.005 & 0.995 & 0.003 & 0.004 & 0.951 & 0.861 & 0.036 & 0.023 & 0.006 & 0.055 \\
\hline \multirow[t]{6}{*}{$\begin{array}{l}\text { BEST } \\
\text { Results }\end{array}$} & $\begin{array}{l}\text { \#1 } \\
\text { variable(s) }\end{array}$ & GS & GS, Sal & $\begin{array}{l}\text { GS, Sal, } \\
\text { Temp }\end{array}$ & GS & GS, Sal & $\begin{array}{l}\text { GS, } \\
\text { Sal, } \\
\text { Temp }\end{array}$ & GS, Sal & GS & Temp & GS, Sal & GS & GS, Sal & GS, Sal & Temp \\
\hline & $\begin{array}{l}\text { \#1 } \\
\text { correlation }\end{array}$ & 0.218 & 0.235 & 0.074 & 0.215 & 0.156 & -0.07 & 0.133 & 0.18 & -0.061 & -0.024 & 0.154 & 0.112 & 0.155 & 0.066 \\
\hline & $\begin{array}{l}\text { \#2 } \\
\text { variable(s) }\end{array}$ & $\begin{array}{l}\text { GS, } \\
\text { Sal }\end{array}$ & GS & $\begin{array}{l}\text { Temp, } \\
\text { GS }\end{array}$ & $\begin{array}{l}\text { GS, } \\
\text { Sal }\end{array}$ & $\begin{array}{l}\text { GS, } \\
\text { Sal, } \\
\text { Temp }\end{array}$ & $\begin{array}{l}\text { Temp, } \\
\text { Sal }\end{array}$ & $\begin{array}{l}\text { GS, Sal, } \\
\text { Temp }\end{array}$ & $\begin{array}{l}\text { Sal } \\
\text { GS }\end{array}$ & $\begin{array}{l}\text { Temp, } \\
\text { Sal }\end{array}$ & GS & $\begin{array}{l}\text { GS, } \\
\text { Temp }\end{array}$ & $\begin{array}{l}\text { GS, } \\
\text { Sal, } \\
\text { Temp }\end{array}$ & $\begin{array}{l}\text { Grain } \\
\text { Size }\end{array}$ & $\begin{array}{l}\text { GS, Sal, } \\
\text { Temp }\end{array}$ \\
\hline & $\begin{array}{l}\text { \#2 } \\
\text { correlation }\end{array}$ & 0.214 & 0.189 & 0.073 & 0.213 & 0.14 & -0.061 & 0.126 & 0.178 & -0.06 & -0.024 & 0.129 & 0.091 & 0.144 & 0.059 \\
\hline & $\begin{array}{l}\text { \#3 } \\
\text { variable(s) }\end{array}$ & $\begin{array}{l}\text { GS, } \\
\text { Sal, } \\
\text { Temp }\end{array}$ & $\begin{array}{l}\text { GS, Sal, } \\
\text { Temp }\end{array}$ & $\begin{array}{l}\text { Temp, } \\
\text { Sal }\end{array}$ & $\begin{array}{l}\text { GS, } \\
\text { Sal, } \\
\text { Temp }\end{array}$ & Sal & Temp & GS & $\begin{array}{l}\text { GS, } \\
\text { Sal, } \\
\text { Temp }\end{array}$ & $\begin{array}{l}\text { GS, } \\
\text { Sal, } \\
\text { Temp }\end{array}$ & $\begin{array}{l}\text { GS, } \\
\text { Sal, } \\
\text { Temp }\end{array}$ & $\begin{array}{l}\text { GS, } \\
\text { Sal, } \\
\text { Temp }\end{array}$ & GS & $\begin{array}{l}\text { GS, Sal, } \\
\text { Temp }\end{array}$ & $\begin{array}{l}\text { Temp, } \\
\text { Sal }\end{array}$ \\
\hline & $\begin{array}{l}\text { \#3 } \\
\text { correlation }\end{array}$ & 0.164 & 0.173 & 0.047 & 0.138 & 0.096 & -0.054 & 0.114 & 0.134 & -0.05 & -0.022 & 0.087 & 0.078 & 0.117 & 0.056 \\
\hline $\mathrm{N}$ & & 74 & 74 & 211 & 74 & 74 & 169 & 96 & 109 & 169 & 169 & 109 & 109 & 96 & 96 \\
\hline
\end{tabular}

Table 3.8 Results from analysis of biomarker datasets against environmental parameters: temperature, salinity and median sediment grain size using RELATE and BEST in PRIMER-E. The RELATE score represents significance of the correlation between the biomarkers and concentrations of sediment contaminants: cells with significant correlations are shaded. BEST determines which sediment parameters correlate best to the biomarker data and gives a correlation score.

$\mathrm{BM}=$ biomarkers. GS= median grain size. Sal=salinity. Temp=temperature. 


\begin{tabular}{|c|c|c|c|c|c|c|c|c|c|c|c|c|c|c|c|}
\hline & & $\begin{array}{l}\text { All } \\
\text { BM }\end{array}$ & $\begin{array}{c}\text { Cellular } \\
\text { BM }\end{array}$ & $\begin{array}{l}\text { Morpho } \\
\text { BM }\end{array}$ & EROD & TBARS & $\begin{array}{l}\text { Liver } \\
\text { BM }\end{array}$ & $\begin{array}{c}\text { Kidney } \\
\text { BM }\end{array}$ & $\begin{array}{l}\text { Gill } \\
\text { BM }\end{array}$ & $\begin{array}{l}\text { Liver } \\
\text { EROD }\end{array}$ & $\begin{array}{c}\text { Liver } \\
\text { TBARS }\end{array}$ & $\begin{array}{c}\text { Gill } \\
\text { EROD }\end{array}$ & $\begin{array}{c}\text { Gill } \\
\text { TBARS }\end{array}$ & $\begin{array}{l}\text { Kidney } \\
\text { EROD }\end{array}$ & $\begin{array}{l}\text { Kidney } \\
\text { TBARS }\end{array}$ \\
\hline RELATE & Significance & 0.009 & 0.047 & 0.016 & 0.003 & 0.229 & 0.935 & 0.01 & 0.001 & 0.844 & 0.783 & 0.001 & 0.047 & 0.006 & 0.28 \\
\hline \multirow[t]{6}{*}{$\begin{array}{l}\text { BEST } \\
\text { Results }\end{array}$} & $\begin{array}{l}\text { \#1 } \\
\text { variable(s) }\end{array}$ & $\mathrm{Cu}$ & $\mathrm{Cu}$ & $\mathrm{Cu}$ & $\mathrm{Cu}$ & $\mathrm{Zn}$ & $\mathrm{Zn}$ & $\mathrm{Cu}$ & $\mathrm{Cu}$ & $\mathrm{Zn}$ & PAHs & $\mathrm{Cu}$ & $\mathrm{Cu}$ & $\mathrm{Cu}$ & $\mathrm{Zn}$ \\
\hline & $\begin{array}{l}\# 1 \\
\text { correlation }\end{array}$ & 0.142 & 0.114 & 0.068 & 0.15 & 0.036 & -0.059 & 0.103 & 0.174 & -0.056 & 0.02 & 0.159 & 0.08 & 0.131 & 0.03 \\
\hline & $\begin{array}{l}\text { \#2 } \\
\text { variable(s) }\end{array}$ & $\begin{array}{l}\text { PAHs, } \\
\mathrm{Cu}\end{array}$ & $\begin{array}{c}\text { PAHs, } \\
\mathrm{Cu}\end{array}$ & $\begin{array}{c}\text { PAHs, } \\
\mathrm{Cu}\end{array}$ & $\begin{array}{c}\text { PAHs, } \\
\mathrm{Cu}\end{array}$ & $\mathrm{Cu}, \mathrm{Zn}$ & $\mathrm{Cu}, \mathrm{Zn}$ & $\mathrm{Cu}, \mathrm{Zn}$ & $\begin{array}{l}\mathrm{Cu}, \\
\mathrm{Zn}\end{array}$ & $\begin{array}{l}\text { PAHs, } \\
\text { Zn }\end{array}$ & $\mathrm{Cu}, \mathrm{Zn}$ & $\begin{array}{c}\text { PAHs, } \\
\mathrm{Cu}\end{array}$ & $\mathrm{Cu}, \mathrm{Zn}$ & $\mathrm{Cu}, \mathrm{Zn}$ & PAHs \\
\hline & $\begin{array}{l}\# 2 \\
\text { correlation }\end{array}$ & 0.113 & 0.08 & 0.065 & 0.142 & 0.029 & -0.046 & 0.101 & 0.138 & -0.039 & -0.019 & 0.133 & 0.06 & 0.11 & -0.031 \\
\hline & $\begin{array}{l}\text { \#3 } \\
\text { variable(s) }\end{array}$ & $\begin{array}{l}\mathrm{Cu}, \\
\mathrm{Zn}\end{array}$ & $\mathrm{Cu}, \mathrm{Zn}$ & $\mathrm{Cu}, \mathrm{Zn}$ & PAHs & $\mathrm{Cu}$ & $\begin{array}{c}\text { PAHs, } \\
\text { Zn }\end{array}$ & $\mathrm{Zn}$ & $\begin{array}{c}\text { PAHs, } \\
\mathrm{Cu}\end{array}$ & $\mathrm{Cu}, \mathrm{Zn}$ & $\mathrm{Zn}$ & $\begin{array}{l}\mathrm{Cu}, \\
\mathrm{Zn}\end{array}$ & $\begin{array}{c}\text { PAHs, } \\
\mathrm{Cu}\end{array}$ & $\begin{array}{c}\text { PAHs, } \\
\mathrm{Cu}\end{array}$ & $\mathrm{Cu}, \mathrm{Zn}$ \\
\hline & $\begin{array}{l}\text { \#3 } \\
\text { correlation }\end{array}$ & 0.113 & 0.078 & 0.064 & 0.121 & 0.025 & -0.044 & 0.083 & 0.132 & -0.036 & -0.019 & 0.125 & 0.05 & 0.094 & 0.018 \\
\hline $\mathrm{N}$ & & 74 & 74 & 211 & 74 & 74 & 169 & 96 & 109 & 169 & 169 & 109 & 109 & 96 & 96 \\
\hline
\end{tabular}

Table 3.9 Results from analysis of biomarker datasets against sediment $\mathrm{Cu}$, $\mathrm{Zn}$ and total PAHs using RELATE and BEST in PRIMER-E. The RELATE score represents significance of the correlation between biomarkers and concentrations of sediment contaminants: significant scores are shaded. BEST determines which sediment parameters correlate best to the biomarker data and gives a correlation score. BM=biomarkers. Morpho=morphometric. 


\begin{tabular}{|c|c|c|c|c|c|c|c|c|c|c|c|c|c|c|c|}
\hline & & All BM & $\begin{array}{c}\text { Cellular } \\
\text { BM }\end{array}$ & $\begin{array}{l}\text { Morpho } \\
\text { BM }\end{array}$ & EROD & TBARS & $\begin{array}{c}\text { Liver } \\
\text { BM }\end{array}$ & $\begin{array}{l}\text { Kidney } \\
\text { BM }\end{array}$ & Gill BM & $\begin{array}{l}\text { Liver } \\
\text { EROD } \\
\end{array}$ & $\begin{array}{c}\text { Liver } \\
\text { TBARS }\end{array}$ & $\begin{array}{c}\text { Gill } \\
\text { EROD }\end{array}$ & $\begin{array}{c}\text { Gill } \\
\text { TBARS } \\
\end{array}$ & $\begin{array}{l}\text { Kidney } \\
\text { EROD }\end{array}$ & $\begin{array}{l}\text { Kidney } \\
\text { TBARS } \\
\end{array}$ \\
\hline RELATE & Significance & 0.001 & 0.002 & 0.01 & 0.157 & 0.011 & 0.09 & 0.22 & 0.029 & 0.999 & 0.001 & 0.02 & 0.037 & 0.08 & 0.61 \\
\hline \multirow[t]{6}{*}{$\begin{array}{l}\text { BEST } \\
\text { Results }\end{array}$} & $\begin{array}{l}\text { \#1 } \\
\text { variable(s) }\end{array}$ & $\begin{array}{c}\mathrm{Cu}, \\
\text { PBDEs }\end{array}$ & $\mathrm{Cu}$ & Zn, Pyr & PAHs & $\begin{array}{l}\text { Pyr, } \\
\text { Fip }\end{array}$ & PAHs & $\mathrm{Cu}$ & $\mathrm{Cu}$ & $\begin{array}{l}\text { PAHs, } \\
\text { Zn, } \\
\text { PBDEs }\end{array}$ & $\begin{array}{c}\text { PAHs, } \\
\text { Cu, Zn, } \\
\text { Fip }\end{array}$ & $\mathrm{Cu}$ & $\begin{array}{l}\mathrm{Cu}, \\
\text { Pyr, } \\
\text { Fip }\end{array}$ & $\mathrm{Cu}$ & $\begin{array}{l}\text { Pyr, } \\
\text { Fip }\end{array}$ \\
\hline & $\begin{array}{l}\text { \#1 } \\
\text { correlation }\end{array}$ & 0.198 & 0.148 & 0.126 & 0.115 & 0.125 & 0.06 & 0.078 & 0.158 & -0.047 & 0.132 & 0.143 & 0.098 & 0.106 & 0.025 \\
\hline & $\begin{array}{l}\text { \#2 } \\
\text { variable(s) }\end{array}$ & $\mathrm{Cu}$ & $\begin{array}{c}\mathrm{Cu}, \\
\text { PBDEs }\end{array}$ & $\begin{array}{l}\text { Zn, Pyr, } \\
\text { PBDEs }\end{array}$ & $\begin{array}{c}\text { PAHs, } \\
\mathrm{Cu}\end{array}$ & Pyr & $\mathrm{Zn}$ & $\begin{array}{l}\mathrm{Cu}, \mathrm{Zn}, \\
\text { PBDEs }\end{array}$ & $\mathrm{Cu}, \mathrm{Pyr}$ & $\begin{array}{c}\text { PAHs, } \\
\text { Cu, } \\
\text { PBDEs }\end{array}$ & $\begin{array}{l}\mathrm{Cu}, \mathrm{Zn}, \\
\text { Fip }\end{array}$ & $\begin{array}{c}\text { PAHs, } \\
\mathrm{Cu}\end{array}$ & $\mathrm{Cu}$, Fip & $\mathrm{Cu}, \mathrm{Zn}$ & Pyr \\
\hline & $\begin{array}{l}\text { \#2 } \\
\text { correlation }\end{array}$ & 0.189 & 0.127 & 0.122 & 0.114 & 0.12 & 0.054 & 0.065 & 0.134 & -0.046 & 0.132 & 0.106 & 0.098 & 0.083 & 0.025 \\
\hline & $\begin{array}{l}\text { \#3 } \\
\text { variable(s) }\end{array}$ & $\begin{array}{l}\mathrm{Cu}, \mathrm{Zn}, \\
\text { PBDEs }\end{array}$ & $\mathrm{Cu}, \mathrm{Pyr}$ & $\begin{array}{c}\text { Zn, } \\
\text { PBDEs }\end{array}$ & $\mathrm{Cu}$ & $\begin{array}{c}\text { Pyr, } \\
\text { PBDEs }\end{array}$ & $\begin{array}{l}\text { PAHs, } \\
\text { Zn }\end{array}$ & $\mathrm{Cu}, \mathrm{Zn}$ & $\begin{array}{c}\mathrm{Cu}, \\
\text { PBDEs }\end{array}$ & $\begin{array}{l}\text { PAHs, } \\
\text { PBDEs }\end{array}$ & Zn, Fip & $\begin{array}{c}\mathrm{Cu}, \\
\text { PBDEs }\end{array}$ & $\begin{array}{l}\text { Cu, Fip, } \\
\text { PBDEs }\end{array}$ & $\begin{array}{c}\mathrm{Cu}, \\
\text { PBDEs }\end{array}$ & Fip \\
\hline & $\begin{array}{l}\text { \#3 } \\
\text { correlation }\end{array}$ & 0.187 & 0.106 & 0.121 & 0.111 & 0.119 & 0.051 & 0.065 & 0.132 & -0.042 & 0.132 & 0.102 & 0.095 & 0.082 & 0.025 \\
\hline $\mathrm{N}$ & & 49 & 49 & 127 & 50 & 81 & 103 & 58 & 78 & 103 & 103 & 78 & 78 & 58 & 58 \\
\hline
\end{tabular}

Table 3.10 Results from analysis of biomarker datasets against sediment $\mathrm{Cu}, \mathrm{Zn}$, total PAHs, total pyrethroids, total fipronils and total PBDEs using RELATE and BEST in PRIMER-E. The RELATE score represents significance of the correlation between biomarkers and concentrations of sediment contaminants: significant scores are shaded. BEST determines which sediment parameters correlate best to the biomarker data and gives a correlation score. BM=biomarkers.

Morpho=morphometric. Pyr=total pyrethroids. Fip=total fipronils. 


\section{6 - References}

Amara, R., Meziane, T., Gilliers, C., Mermel, G. and Laffargue, P. 2007. Growth and condition indices in juvenile sole Solea solea measured to assess the quality of essential fish habitat. Marine Ecology Progress Series 351:201-208.

Bradford, M.M. 1976. A rapid and sensitive method for the quantitation of microgram quantities of protein utilizing the principle of protein-dye bonding. Analytical Biochemistry 72:248-254.

Brown, J.S. and Steinert, S.A. 2003. DNA damage and biliary PAH metabolites in flatfish from Southern California bays and harbors, and the Channel Islands. Ecological Indicators 3:263-274.

California Department of Fish and Game. 2012. Review of selected California fisheries for 2011: ocean salmon, California sheephead, California halibut, longnose skate, petrale sole, California spiny lobster, dungeness crab, garibaldi, white shark and algal blooms. Fisheries Review (CalCOFI Report) 53: 1-40.

Celander, M.C. 2011. Cocktail effects on biomarker responses in fish. Aquatic Toxicology 1055: 72-77.

Costa, P.M, Caeiro, S., Diniz, M.S., Lobo, J., Martins, M., Ferreira, A.M., Caetano, M., Vale, C., DelValls, T.A. and Costa M.H. 2009a. Biochemical endpoints on juvenile Solea senegalensis exposed to estuarine sediments: effect of contaminant mixtures on metallothionein and CYP1A induction. Ecotoxicology 18: 988-1000.

Costa, P.M., Diniz, M.S., Caeiro, S., Lobo, J., Martins, M., Ferreira, A.M., Caetano, M., Vale, C., DelValls, T.A., and Costa M.H. 2009b. Histological biomarkers in liver and gills of juvenile Solea senegalensis exposed to contaminated estuarine sediments: A weighted indices approach. Aquatic Toxicology 92: 202-212.

Costa, P.M., Caeiro, S., Lobo, J., Martins, M., Ferreira, A.M., Caetano, M., Vale, C., DelValls, T.A. and Costa, M.H. 2011. Estuarine ecological risk based on hepatic histopathological indices from laboratory and in situ tested fish. Marine Pollution Bulletin 62: 55-65.

Donham, R.T., Luna, D.L., Chang, S., Morin, D., Jewell, W.T., Tjeerdema, R.S. 2007. Characterization of cytosolic glutathione S-transferase in California halibut (Paralichthys californicus). Ecotoxicology and Environmental Safety 66: 133-138.

Eggleton, J. and Thomas, K.V. 2004. A review of factors affecting the release and bioavailability of contaminants during sediment disturbance events. Environment International 30: 973-980.

Fang, J.K.H., Au, D.W.T., Chan, A.K.Y., So, L.K.Y, Liu, W., Mok, H.O.L., Yu, W., Wu, R.S.S. and Shin, P.K.S. 2010. Ethoxyresorufin-O-deethylase enzyme activities and accumulation of secondary/tertiary lysosomes in rabbitfish Siganus oramin as biomarkers for xenobiotic exposures. Science of the Total Environment 408: 4833-4840.

Fernandes, C., Fontainhaus-Fernandes, A., Cabral, D. and Salgado, A. 2008. Heavy metals in water, sediment and tissues of Liza saliens from Esmoriz-Paramos lagoon, Portugal. Environmental Monitoring and Assessment 136:267-275.

Ferreira, M., Antunes, P., Gil, O., Vale, C. and Reis-Henriques, M.A. 2004. Organochlorine contaminants in flounder (Platichthys flesus) and mullet (Mugil cephalus) from Douro estuary, and their use as sentinel species for environmental monitoring. Aquatic Toxicology 69: 347-357. 
Ferreira, M., Moradas-Ferreira, P. and Reis-Henriques, M.A. 2005. Oxidative stress biomarkers in two resident species, mullet (Mugil cephalus) and flounder (Platichthys flesus), from a polluted site in River Douro Estuary, Portugal. Aquatic Toxicology 71:3948.

Fodrie, F.J. and Herzka, S.Z. 2008. Tracking juvenile fish movement and nursery contribution within arid coastal embayments via otolith microchemistry. Marine Ecology Progress Series 361: 253-265.

Fodrie, F.J. and Herzka, S.Z. 2013. A comparison of otolith geochemistry and stable isotope markers to track fish movement: describing estuarine ingress by larval and postlarval halibut. Estuaries and Coasts 6:209-217.

Fodrie, F.J. and Levin, L.A. 2008. Linking juvenile habitat utilization to population dynamics of California halibut. Limnology and Oceanography 53: 799-812.

Fodrie, F.J. and Mendoza, G. 2006. Availability, usage and expected contribution of potential nursery habitats for the California halibut. Estuarine, Coastal and Shelf Science 68: $149-164$.

Fodrie, F.J., Levin, L.A., Lucas, A.J. 2009. Use of population fitness to evaluate the nursery function of juvenile habitats. Marine Ecology Progress Series 385: 39-49.

Forrester, G.E. and Swearer, S.E. 2002. Trace elements in otoliths indicate the use of open-coast versus bay nursery habitats by juvenile California halibut. Marine Ecology Progress Series 241: 201-213.

Fonseca, V.F., Frana, S., Serafim, A., Company, R., Lopes, B., Bebianno, M.J., Cabral, H.N. 2011a. Multi-biomarker responses to estuarine habitat contamination in three fish species: Dicentrarchus labrax, Solea senegalensis and Pomatoschistus microps. Aquatic Toxicology 102: 216-227.

Fonseca, V.F., Frana, S., Vasoncelos, R.P., Serafim, A., Company, R., Lopes, B., Bebianno, M.J., Cabral, H.N. 2011b. Short-term variability of multiple biomarker response in fish from estuaries: influence of environmental dynamics. Marine Environmental Research 72: 172-178.

Huggett, R.J., Stegeman, J.J., Page, D.S., Parker, K.R., Woodin, B. and Brown, J.S. 2003. Biomarkers in fish from Prince William Sound and the Gulf of Alaska: 1999-2000. Environmental Science and Technology 37: 4043-4051.

Jebali, J., Sabbagh, M., Banni, M., Kamel, N., Ben-Khedher, S., M'hamdi, N. and Boussetta, H. 2013. Multiple biomarkers of pollution in Solea solea fish on the Tunisia coastline. Environmental Science and Pollution Research 20: 3812-3821.

Jentzsch, A.M., Bachmann, H., Furst, P. and Biesalski, H.K. 1996. Improved analysis of malondialdehyde in human body fluids. Free Radicals in Biology and Medicine 20: 251256.

Kaufmann, R.S., B.C. Stransky, D.T. Elliott, E. Kraak, D. Twal and K. Watters. 2006. Mission Bay Citizen Water Quality Monitoring and Education Program, Final Report. California State Water Resources Control Board, 12 pp.

Kerambrun, E., Henry, F., Perrichon, P., Courcot, L., Meziane, T., Spilmont, N. and Amara, R. Growth and condition indices of juvenile turbot, Scophthalmus maximus, exposed to contaminated sediments: Effects of mettlic and organic compounds. Aquatic Toxicology 108:130-140. 
Khan, R.A. 2003. Health of flatfish from localities in Placentia Bay, Newfoundland, contaminated with petroleum and PCBs. Archives of Environmental Contamination and Toxicology 44:485-492.

Kopecka-Pilarczyk, J. 2013. Comparison of selected biomarkers in flounder (Platichthys flesus L.) from the Douro (Portugal) and Vistula (Poland) River estuaries. Marine Pollution Bulletin 73: 70-77.

Kramer, S. 1991. Growth, Mortality, and Movements of Juvenile California Halibut Paralichthys californicus in Shallow Coastal and Bay Habitats of San Diego County, California. U.S. Fishery Bulletin 89: 195-207.

Kumari, K., Khare, A. and Dange, S. 2014. The applicability of oxidative stress biomarkers in assessing chromium induced toxicity in the fish Labeo rohita. BioMed Research International 2014:1-11.

Lao, W., Tiefenthaler, L., Greenstein, D.J., Maruya, K.A., Bay, S.M., Ritter, K. and Schiff, K. 2012. Pyrethroids in southern California coastal sediments. Environmental Toxicology and Chemistry 31: 1649-1656.

Lavado, R., Thibaut, R., Raldua, D., Martin, R. and Porte, C. 2004. First evidence of endocrine disruption in feral carp from the Ebro River. Toxicology and Applied Pharmacology 196:247-257.

Lavado, R. Urena, R., Martin-Skilton, R., Torreblanca, A., del Ramo, J., Raldua, D. and Porte, C. 2006. The combined use of chemical and biochemical markers to assess water quality along the Ebro River. Environmental Pollution 139: 330-339.

Lpez -Rasgado, F.J. and Herzka, S.Z. 2009. Assessment of habitat quality for juvenile California halibut (Paralichthys californicus) in a seasonally arid estuary. Fishery Bulletin 107: 343-358.

Lu, G.H., Qi, P.D. and Chen, W. 2013. Integrated biomarker responses of Carassius auratus exposed to BDE-47, BDE-99 and their mixtures. International Journal of Environmental Research 7: 807-816.

Madon, S.P. 2002. Ecophysiology of juvenile California halibut Paralichthys californicus in relation to body size, water temperature and salinity. Marine Ecology Progress Series 243: 235-249.

Martnez -'lvarez, R.M., Morales, A.E. and Sanz, A. 2005. Antioxidant defenses in fish: biotic and abiotic factors. Reveiws in Fish Biology and Fisheries 15: 75-88.

Mendez, J.L., Rodriguez, M.H., and Ramirez, L.F.B. 2010. Thermal tolerance and compatibility zones as a tool to establish the optimum culture condition of the halibut Paralichthys californicus. Aquaculture Research 41: 1015-1021.

Minghetti, M., Leaver, M.J., Carpent, E. and George, S.G. 2008. Copper transporter 1, metallothionein and glutathione reductase genes are differentially expressed in tissues of sea bream (Sparus aurata) after exposure to dietary or waterborne copper. Comparitive biochemistry and Physiology 147: 450-459.

Pereira, J.J., Mercaldo-Allen, R., Kuropat, C., Luedke, D. and Sennefelder, G. 1993. Effect of cadmium accumulation on serum bitellogenin levels and hepatosomatic and gonadosomatic indices of winter flounder (Pleuronectes americanus). Archives of Environmental Contamination and Toxicology 24:427-431. 
Pereira, P., de Pablo, H., Pacheco, M. and Vale, C. 2010a. The relevance of temporal and organ specific factors on metals accumulation and biochemical effects in feral fish (Liza aurata) under a moderate contamination scenario. Ecotoxicology and Environmental Safety 73: 805-816.

Pereira, P., de Pablo, H., Vale, C. and Pacheco, M. 2010b. Combined use of environmental data and biomarkers in fish (Liza aurata) inhabiting a eutrophic and metalcontaminated coastal system - Gills reflect environmental contamination. Marine Environmental Research 69: 53-62.

Roy, L.A., Steinert, S., Bay, S.M., Greenstein, D., Sapozhnikova, Y., Bawardi, O., Leifer, I. and Schlenk, D. 2003. Biochemical effects of petroleum exposure in hornyhead turbot (Pleuronichthys verticalis) exposed to a gradient of sediments collected from a natural petroleum seep in CA, USA. Aquatic Toxicology 65: 159-169.

Schlenk, D., Sapozhnikova, Y., Irwin, M.A., Xie, L., Hwang, W., Reddy, S., Brownawell, B.J., Armstrong, J., Kelly, M., Montagne, D.E., Kolodzieg, E.P., Sedlak, D. and Snyder, S. 2005. In-vivo bioassay guided fractionation of marine sediment extracts from the Southern California Bight, USA, for estrogenic activity. Environmental Toxicology and Chemistry 24: 2820-2826.

Seruto, C., Sapozhinikova, Y. and Schlenk, D. 2005. Evaluation of the relationships between biochemical endpoints of PAH exposure and physiological endpoints of reproduction in male California Halibut (Paralichthys californicus) exposed to sediments from a natural oil seep. Marine Environmental Research 60: 454-465.

Silva Barni, M.F., Gonzalez, M. and Miglioranza K.S.B. 2014. Assessment of persistent organic pollutants accumulation and lipid peroxidation in two reproductive stages of wild silversides (Odontesthes bonariensis). Ecotoxicology and Environmental Safety 99: 4553.

SolØ, M., Ant, M., Baena, M., Carrasson, M., Cartes, J.E. and Maynou, F. 2010. Hepatic biomarkers of xenobiotic metabolism in eighteen marine fish from NW Mediterranean shelf and slope waters in relation to some of their biological and ecological variables. Marine Environmental Research 70: 181-188.

Stransky, C. 1999. Assessment of sediment quality effects in Mission Bay and San Diego Bay on the growth, behavior and survival of California halibut (Paralichthys californicus). SDSU Masters Thesis.

Szebedinsky, C., McGeer, J.C., McDonald, D.G. and Wood, C.M. 2001. Effects of chronic $\mathrm{Cd}$ exposure via the diet or water on internal organ-specific distribution and subsequent gill $\mathrm{Cd}$ uptake kinetics in juvenile rainbow trout (Oncorhynchus mykiss). Environmental Toxicology and Chemistry 20: 597-607.

Taju, G., Abdul Majeed, S., Nambi, K.S.N., Farook, M.A., Vimal, S. and Sahul Hameed, A.S. 2014. In vitro cytotoxic, genotoxic and oxidative stress of cypermethrin on five fish cell lines. Pesticide Biochemistry and Physiology 113: 15-24.

Van der Oost, R., Beyer, J., Vermeulen, N. 2003. Fish bioaccumulation and biomarkers in environmental risk assessment: a review. Environmental Toxicology and Pharmacology 13: 57-149.

Vieira, L.R., Gravato, C., Soares, A.M.V.M, Morgado, F. and Guilhermino, L. 2009. Acute effects of copper and mercury on the estuarine fish Pomatoschistus microps: linking biomarkers to behavior. Chemosphere 76: 1416-1427. 
Whyte, J.J., Jung, R.E., Schmitt, C.J and Tillitt, D.E. 2000. Ethoxyresorufin-O-deethylase (EROD) activity in fish as a biomarker of chemical exposure. Critical Reviews in Toxicology 30: 347-570.

Yang, X. and Baumann, P.C. 2006. Biliary PAH metabolites and the hepatosomatic index of brown bullheads from Lake Erie tributaries. Ecological Indicators 6:567-574.

Zhang, Z. and Hu, J. 2008. Effects of p,p'-DDE exposure on gonadal development and gene expression in Japanese medaka (Oryzias latipes). Journal of Environmental Sciences 20:347-352. 


\section{Chapter 4-Summary and Conclusions}

\section{1 - Thesis Summary}

This study aimed to evaluate the biological response of juvenile California halibut (Paralichthys californicus) exposed to a contamination gradient in Mission Bay, San Diego, CA using biomarkers. The following hypotheses were tested:

$\mathrm{H}_{\mathrm{O}} 1$ : There is no difference between sediment contaminant concentrations in the back vs. the front of Mission Bay

$\mathrm{H}_{0}$ 2: Sediments in Mission Bay show no temporal variation in terms of sediment contaminant concentrations

$\mathrm{H}_{0} 3$ : Halibut show the same biomarker responses regardless of which region of the bay they are caught in

$\mathrm{H}_{0} 4$ : Biomarker responses will not be different among tissues or between combined biomarker indices

The first hypothesis has already been partly refuted based on previous work (Kaufmann et al. 2006), but was confirmed when contaminants of emerging concern were evaluated. Metals were found to be elevated in the back bay, especially in channels, compared to sites in the front bay. The exception was in boat basins, where the concentrations of copper were higher than in any other area measured within the bay and zinc was also elevated similar to areas in the back bay. PAHs were elevated in the back bay and in boat basins relative to the front bay sites. Channel samples had higher mean concentrations of PAHs compared to beach samples. Fipronil, its degredates, PBDEs, and pyrethroids all had a similar distribution throughout the bay. They were not found in beach samples from Mariners Cove, Ventura Cove or Fiesta Bay, but were found in increasing concentrations in the beach samples from Crown Point, Cudahy Creek and Tecolote Creek. Channel samples from Crown Point, Cudahy Creek and Tecolote Creek had higher concentrations than beach samples, while samples from Tecolote Creek basin had the highest concentrations of any samples.

The second hypothesis was also refuted based on the results of the seasonal sampling in this study and previous studies (Kaufmann et al. 2006). Not 
all contaminants were sampled over the whole season, and some of the sites (channel sites) were not sampled during every season. Sediment grain size and percent fine fraction had significant changes over the course of the year, which can in part be contributed to runoff bringing fine particles out of the watersheds and into the bay. Contaminants were more variable, but metals and PAHs all showed an increase after the first rainfall event although sometimes not until several days afterwards. More time-intensive studies would help eliminate the possibility of spatial heterogeneity impacting these patterns, but the methods used and past work support making this conclusion.

The third hypothesis can be refuted based on the results of this study. However, the pattern of biomarker responses did not match the expectations based on previous studies of sediment contaminant concentrations in Mission Bay. It was expected that halibut from the back of the bay would have a more pronounced biomarker response since there are elevated levels of contaminants in the back of the bay, while halibut from the front of the bay would have very low biomarker responses. Instead, biomarker responses were found to be higher in the back of the bay as well as in the front of the bay, while the lowest biomarker responses were seen in the middle of the bay. This was common across all biomarkers and tissues measured. The reason for this result is thought to be twofold; 1) boat basins in the front of the bay act as "hot spots" of sediment contamination that halibut may move in and out of and 2) the movement of halibut in and out of the bay likely captures some fish that have spent time in more polluted areas of the back bay and are migrating toward the mouth of the bay. The effect of rainfall on biomarkers is not clear based on the sampling regime in this study, but in general the fact that fall and winter had higher mean biomarker values relative to other seasons warrants further investigation. Further studies with more intense sampling around rainfall events would be needed to adequately address this question.

The last hypothesis can be refuted based on the results of this study. Gill was the best tissue in terms of reflecting sediment contaminant concentrations. The combination of the two gill biomarkers also proved to be a useful tool for 
looking at correlation to sediment contaminant concentrations. The morphological biomarker hepatosomatic index performed well in determining areas of the bay that had higher sediment contaminant concentrations. Liver cellular biomarkers performed poorly overall, with only liver TBARS showing a response to sediment contamination at each site and correlation to the sediment chemistry when pesticides were added to the analysis. Kidneys were the worst tissue in terms of reflecting sediment contaminant concentrations, and it is not recommended to use kidneys in further studies on this species with these biomarkers. The combined biomarker indices had mixed success, but it seems that some were significantly correlated to sediment contaminant concentrations using individual tissues or specific tissue biomarkers. Therefore, it seems that a weighted system needs to be used as has been seen in histopathological studies (Costa et al. 2009b). Another complexity of this approach, which this study did not account for, is the difference in biological relevance of each biomarker as one represents an up-regulation of defensive proteins while the other reflects cell damage from oxidative stress. Biologically, these two endpoints have different consequences on the cells, organs, and organisms. So indeed it seems appropriate to modify the approach used in this study to combine multiple biomarkers of different endpoints in the future. Even so, when TBARS and EROD were looked at separately across tissues, the combination of tissues was not more helpful than individual tissues. Due to some tissues having more significant correlations with other endpoints (i.e. gills), adding in the other tissues did not alter the strength of correlation to the sediment parameters. This study offers some a priori knowledge as to which tissues might have the most useful combined index in the future, but in general the morphometric hepatosomatic index and individual tissues biomarkers were the most useful.

\section{2 - Limitations}

The sediment contaminant aspect of this study was largely limited by not having quantitative measurements of the input for each of the creek sites during the rainy season. While we can hypothesize about the transport of materials from the urban watersheds to the receiving waters, data on the input of fine particles as 
well as dissolved and total contaminants would reinforce the findings of this study.

One of the biggest limitations of this study was the lack of a reference site outside of Mission Bay. Sites used in other studies in Southern California that could have been used are the coast off of Dana Point (Schlenk et al. 2005, Maruya et al. 2012) and the coast off of Camp Pendleton (Brown and Steinert 2003). Unfortunately, resources for coastal collection of juvenile halibut were not available within the program. Adding a coastal component to this study also was unfeasible considering the scale of the project (both in time and space) and the reliance on undergraduate volunteers to assist in much of the collection efforts. A way to overcome this limitation would be to obtain hatchery-raised California halibut and raise them to comparable sizes to those caught in Mission Bay. This option was explored, but no hatchery in Southern California was growing out California halibut and the use of broodstock was 1) not an option from the perspective of the hatcheries and 2) not comparable to juvenile halibut due to the confounding nature of mature gonads and seasonal spawning patterns. Another option would have been to use some of the halibut for depuration studies to establish baseline levels, however this would have required more collection efforts or would have reduced the $\mathrm{N}$ values for biomarkers in this study. In addition, it would require extra resources and space to keep and maintain the fish for the duration of the study.

\section{3 - Future Work}

Future work on California halibut would greatly benefit from a detailed tagging study that could describe the movement patterns of juvenile and sub-adult halibut within embayment habitats. Given that estimates of resident halibut in any given year in Mission Bay are in the tens of thousands (Fodrie and Mendoza 2006) and in San Diego Bay are in the hundreds of thousands, perhaps acoustic tagging to track movement with responders would be the most effective. Tag and recapture methods are likely to run into trouble gaining enough data to have good statistical power. 
Future work on halibut biomarkers would benefit from establishing baseline values for juveniles of comparable sizes used in this study $(2-32 \mathrm{~cm})$ from hatchery raised halibut and those captured in reference areas of the coast that have been used for previous halibut studies (Brown and Steinert 2003, Schlenk et al. 2005, Maruya et al. 2012). This would help to determine if there is significant induction or inhibition of biomarkers such as EROD that have complex relationships with mixtures of sediment contaminants (Celendar 2011).

Other biomarkers to consider for future work on this species are bile FACs to reflect the metabolism of PAHs (Brown and Steinert 2003, Seruto et al. 2005), liver DNA damage (Brown and Steinert 2003), and glutathione S-transferases (GST) since it has been previously characterized in this species (Donham et al. 2007). Since gills appear to be good indicators of sediment contamination it could also be useful to characterize any histological abnormalities observed in the cells under a microscope.

The effect of route of exposure on these fish would also be useful when interpreting future biomarker or bioaccumulation work. It was observed in this study that some fish had sediment in the gut contents, so it is likely that this is a contributing factor to observed biomarker responses in certain tissues. A study that uses diet versus waterborne exposure to contaminants would help this facet of the interpretation.

\section{4 - References}

Brown, J.S. and Steinert, S.A. 2003. DNA damage and biliary PAH metabolites in flatfish from Southern California bays and harbors, and the Channel Islands. Ecological Indicators 3:263-274.

Celander, M.C. 2011. Cocktail effects on biomarker responses in fish. Aquatic Toxicology 1055: 72-77.

Costa, P.M., Diniz, M.S., Caeiro, S., Lobo, J., Martins, M., Ferreira, A.M., Caetano, M., Vale, C., DelValls, T.A., and Costa M.H. 2009b. Histological biomarkers in liver and gills of juvenile Solea senegalensis exposed to contaminated estuarine sediments: A weighted indices approach. Aquatic Toxicology 92: 202-212.

Donham, R.T., Luna, D.L., Chang, S., Morin, D., Jewell, W.T., Tjeerdema, R.S. 2007. Characterization of cytosolic glutathione S-transferase in California halibut (Paralichthys californicus). Ecotoxicology and Environmental Safety 66: 133-138. 
Fodrie, F.J. and Mendoza, G. 2006. Availability, usage and expected contribution of potential nursery habitats for the California halibut. Estuarine, Coastal and Shelf Science 68: $149-164$.

Kaufmann, R.S., B.C. Stransky, D.T. Elliott, E. Kraak, D. Twal and K. Watters. 2006. Mission Bay Citizen Water Quality Monitoring and Education Program, Final Report. California State Water Resources Control Board, 12 pp.

Maruya, K.A., Vidal-Dorsch, D.E., Bay, S.M., Kwon, J.W., Xia, K. and Armbrust, K.L. 2012. Organic contaminants of emerging conern in sediments and flatfish collected near outfalls discharging treated wastewater effluent to the Southern California Bight. Environmental Toxicology and Chemistry 31; 2683-2688.

Schlenk, D., Sapozhnikova, Y., Irwin, M.A., Xie, L., Hwang, W., Reddy, S., Brownawell, B.J., Armstrong, J., Kelly, M., Montagne, D.E., Kolodzieg, E.P., Sedlak, D. and Snyder, S. 2005. In-vivo bioassay guided fractionation of marine sediment extracts from the Southern California Bight, USA, for estrogenic activity. Environmental Toxicology and Chemistry 24: 2820-2826. 


\section{Appendix A - Detailed Biomarker Methods}

\section{Fish Microsomal Isolation}

Method by Lavado et al. (2004) with minor modifications

Lavado, R., Thibaut, R., Raldua, D., Martin, R., and Porte, C. 2004. First evidence of endocrine disruption in feral carp from the Ebro River. Toxicology and Applied Pharmacology 196: 247-257.

Homogenization Buffer

1. Dissolve 17.4 $\mathrm{g} \mathrm{K}_{2} \mathrm{HPO}_{4}$ (MW=174.18) in $1 \mathrm{~L}$ Milli-Q water. Dissolve $6.8 \mathrm{~g} \mathrm{KH}_{2} \mathrm{PO}_{4}(\mathrm{MW}=136.1)$ in $0.5 \mathrm{~L}$ Milli-Q water. Take both to fridge and chill to $4^{\circ} \mathrm{C}$.

2. Mix the two buffers until $\mathrm{pH}=7.4$ (approx.. $300 \mathrm{~mL} \mathrm{KH}_{2} \mathrm{PO}_{4}$ and 600 $\mathrm{mL} \mathrm{K}_{2} \mathrm{HPO}_{4}$ ).

3. Add 1 mM EDTA (MW=372.24, 0.292 g per $1 \mathrm{~L})$.

4. Add $150 \mathrm{mM} \mathrm{KCl}(11.18 \mathrm{~g}$ per $1 \mathrm{~L})$.

Microsomal Buffer

1. Dissolve 17.4 $\mathrm{g} \mathrm{K}_{2} \mathrm{HPO}_{4}$ (MW=174.18) in $1 \mathrm{~L}$ Milli-Q water. Dissolve $6.8 \mathrm{~g} \mathrm{KH}_{2} \mathrm{PO}_{4}$ (MW=136.1) in 0.5 L Milli-Q water. Take both to fridge and chill to $4^{\circ} \mathrm{C}$.

2. Mix the two buffers until $\mathrm{pH}=7.4$ (approx.. $300 \mathrm{~mL} \mathrm{KH}_{2} \mathrm{PO}_{4}$ and 600 $\mathrm{mL} \mathrm{K}_{2} \mathrm{HPO}_{4}$ ).

3. Add 1 mM EDTA (MW=372.24, 0.292 g per $1 \mathrm{~L}$ ).

4. Add $150 \mathrm{mM} \mathrm{KCl}(11.18 \mathrm{~g}$ per $1 \mathrm{~L})$.

5. Add $20 \%$ glycerol.

1. Homogenize sample in homogenization buffer $(1: 5 \mathrm{w} / \mathrm{v}, \sim 5 \mathrm{~mL}$ for liver, $\sim 3$ for kidney/gill) while on ice.

2. Centrifuge $30 \mathrm{~min}$ at $12,000 \mathrm{~g}$ and $4^{\circ} \mathrm{C}$. Get the supernatant (microsomes and cytosol). Discard pellet.

3. Ultracentrifuge $90 \mathrm{~min}$ at $100,000 \mathrm{~g}$ and $4^{\circ} \mathrm{C}$. In the supernatant there are the cytosolic proteins. In the pellet there are the microsomes.

4. Pipette out supernatant and store in $-80^{\circ} \mathrm{C}$ freezer until use.

5. Re-suspend pellet in 1:10 w/v ( $\sim 2 \mathrm{~mL}$ for liver, $\sim 1-2$ for kidney/gill) in microsomal buffer. Vortex for 30 seconds, store in $-80^{\circ} \mathrm{C}$ freezer until use. 


\section{Protein Content Determination (Bradford Method)}

Bradford, M.M. 1976. A rapid and sensitive method for the quantitation of microgram quantities of protein utilizing the principle of protein-dye bonding. Analytical Biochemistry 72:248-254.

\section{Utilized kit from PIERCE}

-Albumin Standard (Prod 23209)

-Coomasie Plus ${ }^{\text {TM }}$ Protein Assay Reagent (Prod 1856210)

Albumin Standard Calibration

1. Standard is at $2 \mathrm{mg} / \mathrm{mL}$. It is necessary to dilutue in order to obtain concentrations for standard curve

a. Concentrations needed $(1,500 \mu \mathrm{g} / \mathrm{mL}, 1,000 \mu \mathrm{g} / \mathrm{mL}, 750$ $\mu \mathrm{g} / \mathrm{mL}, 500 \mu \mathrm{g} / \mathrm{mL}, 250 \mu \mathrm{g} / \mathrm{mL}, 125 \mu \mathrm{g} / \mathrm{mL}, 25 \mu \mathrm{g} / \mathrm{mL}$ and $0 \mu \mathrm{g} / \mathrm{mL}$ (blank)

1. Dilute sample $1 / 20$ for liver or $1 / 5$ for kidney/gill with same buffer (microsomal or homogenization).

2. Add $7 \mu \mathrm{L}$ of each standard or samples to wells. Every standard and sample run in triplicate.

3. Add $200 \mu \mathrm{L}$ Coomasie Plus ${ }^{\mathrm{TM}}$ Protein Reagent per well.

4. Incubate $10 \mathrm{~min}$ shaking at room temperature.

5. Read the plate at $595 \mathrm{~nm}$.

6. Make calibration standard polynomical (fit $r^{2}=0.99$ ) and calculate the protein content of the samples. 


\section{EROD (Ethoxyresorufin $O$-Dealkylase) Determination}

Method by Lavado et al. (2006) with modifications for plate reading.

Lavado, R. Urena, R., Martin-Skilton, R., Torreblanca, A., del Ramo, J., Raldua, D. and Porte, C. 2006. The combined use of chemical and biochemical markers to assess water quality along the Ebro River. Environmental Pollution 139: 330-339.

$100 \mathrm{mM}$ Phosphate Buffer $\mathrm{pH} 7.4+10 \mathrm{mM} \mathrm{MgCl}_{2}$

1. Dissolve $17.4 \mathrm{~g} \mathrm{~K}_{2} \mathrm{HPO}_{4}(\mathrm{MW}=174.18)$ in $1 \mathrm{~L}$ Milli-Q water. Dissolve $6.8 \mathrm{~g} \mathrm{KH}_{2} \mathrm{PO}_{4}(\mathrm{MW}=136.1$ ) in $0.5 \mathrm{~L}$ Milli-Q water. Take both to fridge and chill to $4^{\circ} \mathrm{C}$.

2. Mix the two buffers until $\mathrm{pH}=7.4$ (approx.. $300 \mathrm{~mL} \mathrm{KH}_{2} \mathrm{PO}_{4}$ and 600 $\mathrm{mL} \mathrm{K}_{2} \mathrm{HPO}_{4}$ ).

3. Add $10 \mathrm{mM} \mathrm{MgCl}_{2}$ (930 $\mathrm{mg}$ in $1 \mathrm{~L}$ phosphate buffer).

\section{$50 \mu \mathrm{M} 7$-Ethoxyresorufin (7-ER)}

1. Dissolve $1.206 \mathrm{mg} / \mathrm{mL}$ in DMSO ( $5 \mathrm{mM})$.

2. Dissolve previous stock $1 / 100$ in ethanol to obtain $50 \mu \mathrm{M}$.

5 mM NADPH Solution (Nicotinamide Adenine Dinucleotide Phosphate Reduced form).

1. Dissolve $4.167 \mathrm{mg} / \mathrm{mL}$ in $100 \mathrm{mM}$ phosphate buffer.

$\underline{\text { Resorufin Standards }}$

1. Dissolve $4.26 \mathrm{mg} / \mathrm{mL}$ in ethanol (20 mM, Stock A).

2. Dilute previous stock $1 / 200$ to obtain $100 \mu \mathrm{M}$ (Stock B).

3. Dilute Stock B to obtain concentrations for standard curve (do not use stock $A$ and $B$, they are too concentrated).

a. $1 \mu \mathrm{M}, 500 \mathrm{nM}, 100 \mathrm{nM}, 50 \mathrm{nM}, 10 \mathrm{nM}, 1 \mathrm{nM}, 500 \mathrm{pM}$.

1. Add microsome sample $(0.1 \mathrm{mg} / \mathrm{mL}$ protein $)$ and buffer to volume of 390 $\mu \mathrm{L}$ in $2 \mathrm{~mL}$ tube.

2. Add $10 \mu \mathrm{L}$ of $50 \mu \mathrm{M} 7$-ER solution.

3. Add $100 \mu \mathrm{L}$ of $5 \mathrm{mM}$ NADPH solution (this is the start of the reaction).

4. Incubate for $10 \mathrm{~min}$ at $25^{\circ} \mathrm{C}$ with shaking.

5. Add $100 \mu \mathrm{L}$ cold methanol (this is the end of the reaction).

6. Centrifuge $10 \mathrm{~min}$ at $13,000 \mathrm{rpm}$ at room temperature to precipitate proteins

7. Put $200 \mu \mathrm{L}$ of the supernatant in 96 well plate for fluorescence (run in duplicate, applies to standards as well).

8. Determine fluorescence at excitation/emission wavelengths $537 / 583 \mathrm{~nm}$

9. Subtract blank fluorescence to all the wells

10. Create standard calibration curve with resorufin standards, calculate the resorufin $\mathrm{nM}$ in the sample and the pmol of resorufin created.

11. Present data as $\mathrm{pmol} / \mathrm{min} / \mathrm{mg}$ microsomal protein. 


\section{TBARS (ThioBarbituric Acid Reactive Substances) Determination}

Method by Jentzsch et al. (1996) with minor modifications.

Jentzsch, A.M., Bachmann, H., Furst, P. and Biesalski, H.K. 1996. Improved analysis of malondialdehyde in human body fluids. Free Radicals in Biology and Medicine 20: 251-256.

\section{6 mM BHT}

1. Dissolve $2.77 \mathrm{mg}$ of BHT (butylated hydroxyl toluene in $1 \mathrm{~mL}$ of ethanol. $200 \mathrm{mM}$ Ortophosphoric Acid

1. Dissolve $196 \mathrm{mg}$ of ortophosphoric acid in $10 \mathrm{~mL}$ of Milli-Q water. $100 \mathrm{mM} \mathrm{NaOH}$

1. Dissolve $400 \mathrm{mg}$ of $\mathrm{NaOH}$ in $100 \mathrm{~mL}$ of Milli-Q water.

\section{0 mM TBA (ThioBarbituric Acid)}

1. Dissolve $800 \mathrm{mg}$ TBA in $100 \mathrm{~mL}$ of $100 \mathrm{mM} \mathrm{NaOH}$.

Saturated $\mathrm{NaCl}$ Solution

1. Dissolve $36 \mathrm{~g}$ of $\mathrm{NaCl}$ in $100 \mathrm{~mL}$ of Milli-Q water.

MDA (Malondialdehyde) Standards

1. Prepare standards in homogenization liquid.

a. $10 \mu \mathrm{M}, 7 \mu \mathrm{M}, 5 \mu \mathrm{M}, 3 \mu \mathrm{M}, 2.5 \mu \mathrm{M}, 2.1 \mu \mathrm{M}, 1.7 \mu \mathrm{M}, 1.3 \mu \mathrm{M}, 0 \mu \mathrm{M}$ (blank).

1. Add cytosolic sample $(0.1 \mathrm{mg} / \mathrm{mL}$ protein) to $2 \mathrm{~mL}$ tube.

2. Add $25 \mu \mathrm{L} 12.6 \mathrm{mM}$ BHT to samples or standards.

3. Add $200 \mu \mathrm{L}$ of $200 \mathrm{mM}$ ortophosphoric acid.

4. Vortex for 20 seconds.

5. Add $25 \mu \mathrm{L}$ of $110 \mathrm{mM}$ TBA solution and vortex again.

6. Incubate for $45 \mathrm{~min}$ at $90^{\circ} \mathrm{C}$.

7. Put samples in ice to stop reaction, leave for a few minutes to cool completely.

8. Add $500 \mu \mathrm{L}$ of n-butanol and $50 \mu \mathrm{L}$ of saturated $\mathrm{NaCl}$ solution, shake.

9. Centrifuge $2 \mathrm{~min}$ at $13,000 \mathrm{rpm}$ at room temperature

10. Collect $200 \mu \mathrm{L}$ of upper butanol phase and put in 96-well plate (run in duplicate for samples and standards)

11. Determine fluorescence at excitation/emission wavelengths 530/605 nm.

12. Subtract blank fluorescence to all the wells.

13. Create standard calibration curve with MDA standards, calculate MDA concentration for each sample

14. Express data as MDA/g wet weight tissue. 